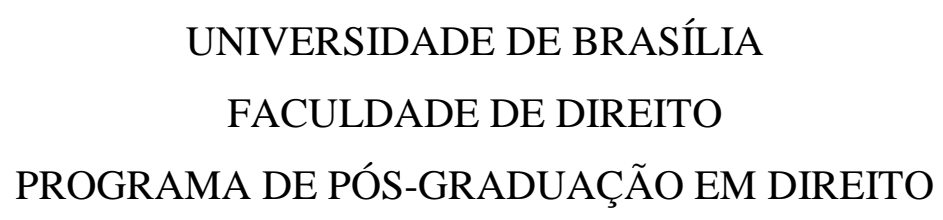

Rafael Campos Soares da Fonseca

\title{
O ORÇAMENTO PÚBLICO E SUAS EMERGÊNCIAS PROGRAMADAS: UM ESTUDO SOBRE A ABERTURA DE CRÉDITOS EXTRAORDINÁRIOS POR MEDIDA PROVISÓRIA (2008-2015)
}




\title{
O ORÇAMENTO PÚBLICO E SUAS EMERGÊNCIAS PROGRAMADAS: UM ESTUDO SOBRE A ABERTURA DE CRÉDITOS EXTRAORDINÁRIOS POR MEDIDA PROVISÓRIA
} (2008-2015)

\author{
Dissertação apresentada no Programa de Pós- \\ Graduação em Direito da Faculdade de Direito da \\ Universidade de Brasília, como requisito parcial \\ para a obtenção do grau de Mestre em Direito - \\ Área de concentração "Direito, Estado e \\ Constituição".
}

Orientador: Professor Dr. Gilmar Ferreira Mendes.

Co-orientadora: Professora Dra. Claudia Rosane Roesler. 


\section{O ORÇAMENTO PÚBLICO E SUAS EMERGÊNCIAS PROGRAMADAS: UM ESTUDO SOBRE A ABERTURA DE CRÉDITOS EXTRAORDINÁRIOS POR MEDIDA PROVISÓRIA (2008-2015)}

Professor Doutor Gilmar Ferreira Mendes (UnB - Orientador)

Professora Doutora Claudia Rosane Roesler (UnB - Co-orientadora)

Professor Doutor (- Examinador Interno)

Professor Doutor (- Examinador Externo)

Professor Doutor (- Examinador Suplente)

Tese defendida e aprovada em:

Brasília-DF, XX de setembro de 2016. 
Aos meus amados pais, Reynaldo e Luziana.

À Karen, meu amor. 


\section{AGRADECIMENTOS}

O presente trabalho somente se tornou possível graças a uma somatória de auxílios prestados a mim, além das incontáveis horas e angústias exigidas por um esforço acadêmico dessa natureza. Nesse sentido, dedico estas singelas linhas para prestar minha gratidão pelo privilégio da convivência com as pessoas a seguir nomeadas.

Agradeço a Deus pelo dom da vida e por me dar forças para cumprir mais esta etapa de minha missão vocacional.

Presto também meus agradecimentos aos meus pais, Reynaldo e Luziana, pelo amor, carinho, conselhos e apoio incondicionais a mim dados ao longo de minha vida. Infelizmente, nunca serei capaz de retribuir ou mensurar os sacrifícios feitos em prol da criação e preservação de nossa família.

Sou grato, ainda, a meus irmãos, Leonardo e Gabriel, pela alegria da companhia fraternal. Aproveito para agradecer a todos os membros das Famílias do Vale, Campos, Soares e da Fonseca.

Uma vez mais, presto minha gratidão à Professora Claudia Roesler pelos mais de cinco anos de orientação, paciência e confiança, desde as aulas de Introdução ao Direito à presente dissertação, perpassando os programas de iniciação científica, grupos de pesquisa, monografia e aulas no mestrado.

Ao Professor e Ministro do STF Gilmar Mendes meu muito obrigado por aceitar orientar-me no presente trabalho, a despeito de atribulada rotina e agenda de compromissos. Igualmente, por me permitir laborar em seu Gabinete por mais de um ano, tempo no qual pude desfrutar do convívio de grandes profissionais. Aproveito o ensejo para agradecer, especialmente, ao atual Chefe de Gabinete Celso Correia Neto, que muito me auxiliou na escolha do presente tema, assim como à Assessora Maria Clara, pela amizade constante.

Ao Ministro do STF Luiz Edson Fachin, mesmo se quisesse, jamais poderia expressar com exatidão e à altura minha gratidão pela oportunidade de conhecê-lo, integrar sua Asessoria e desfrutar de seus ensinamentos, portanto me limito a afirmá-lo meu norte profissional e pessoal. Nessa oportunidade, agradeço o apoio e a convivência da equipe do Gabinete: Paula Boeng, Paula Cristina, Miguel, Roberto, Christine, Matheus, Susana, Fernanda, Luiz e todos os demais. Aos Juízes Federais Ricardo Rachid e Camila Plentz meu agradecimento por tudo.

Sinto-me obrigado aos Professores Valcir Gassen, Marcelo Neves, Paulo Burnier, Henrique Araújo e Marcus Faro pelas lições no âmbito da pós-graduação. Aproveito para 
estender a gratidão à Faculdade de Direito da Universidade de Brasília e às pessoas que a tornaram viva durante meu mestrado, dos funcionários aos colegas.

Ao Professor e Ministro do STJ Luiz Gurgel de Faria por me aceitar na condição de Assistente de Docência na disciplina de Direito Financeiro, assim como pelo exemplo de dedição profissional na Judicatura e Academia.

Ao Professor Fernando Facury Scaff meu termo de confissão de dívida pelos enriquecedores diálogos sobre o Direito Financeiro e a jurisprudência do Supremo Tribunal Federal, além das precisas indicações bibliográficas.

Enfim, agradeço à Karen com todo amor que houver nesta vida, por me aceitar como sou e pelo tempo juntos que lhe furtei para a realização deste trabalho. 
“A premissa é direta: compreender o Direito não é apenas uma operação mecânica, antes é um diálogo permanente entre seres humanos que não deve cessar jamais. Por isso mesmo, o texto que segue é introdutório. Ele também é um fim. Ou recomeço.” (FACHIN, Luiz Edson. Direito Civil: sentidos, transformações e fim. Rio de Janeiro: Renovar, 2015, p. 3)

"Para nós, a estabilidade institucional no Brasil depende de dois fatores: sua adequação efetiva à realidade nacional e o empenho dos grupos dirigentes em aliarem-se para fortalecer as instituições, e não, como sempre aconteceu, para torná-las inviáveis”. (FRANCO, Afonso Arino de Melo. Direito Constitucional: teoria da constituição; as constituições do Brasil. 2 ed. Rio de Janeiro: Forense, 1981, p. 74). 


\section{RESUMO}

A presente pesquisa versa sobre a abertura de créditos extraordinários mediante medidas provisórias no período de 2008-2015. Nesse sentido, tem-se como problema a ocorrência de ofensa sistemática à ordem constitucional, em decorrência da utilização reiterada desse instrumento orçamentário no âmbito federal. A partir da literatura jurídica, aponta-se uma hipótese afirmativa, tendo em vista a periodicidade e o volume de créditos extraordinários abertos. São objetivos da presente pesquisa, na qualidade de contributo acadêmico, evidenciar um tratamento assimétrico entre as receitas e despesas públicas em nível constitucional, assim como repensar os modos em que se desenvolve a Constituição Financeira brasileira no tocante ao princípio da separação dos poderes. Em termos metodológicos, o parâmetro a ser seguido é a metodologia tridimensional estrutrurante (Modelo Dreier-Alexy), divisando o estudo dogmático nas dimensões analítica, empírica e normativa. $\mathrm{O}$ expediente argumentativo da investigação dá-se em três eixos: a elaboração de um perfil normativo referente ao orçamento público que sirva de parâmetro de correção material da conduta estatal no ciclo orçamentário; a verificação da coerência da jurisprudência do Supremo Tribunal Federal acerca do controle abstrato de constitucionalidade de normas orçamentárias; e a extração de padrões decisórios institucionais acerca do fenômeno financeiro estudado para posterior proposição de diagnósticos sobre a interação entre os atores políticos envolvidos na realidade subjacente ao objeto de pesquisa. Conclui-se que o desvirtuamento da ordem constitucional no escopo investigado serve como vantagem institucional a favor do Presidente da República no controle do orçamento público no sistema presidencialista brasileiro.

Palavras-Chave. Orçamento Público. Créditos Extraordinários. Separação dos Poderes. 


\begin{abstract}
This work deals with the opening of extraordinary credits by the aid of provisional measures in the period between 2008 and 2015. In this sense, it is assumed as a problem the occurence of systematic offense direct to the constitutional order in consequence of reiterated utilization of this orçamental instrument in federal level. Based on legal literature, it is indicate an affimartive hypothesis, because of the periodicity and volume of extraordinary credits laid open. As an academical endeveaur, this research aims to evidence an asymetrical treatment of public expenses and revenues on the constitutional level, as well as rethink the ways the Brazilian Budgetary Constitution develops in relation to the separation of powers principle. On the methodological ground, the pattern to be followed is the tridimensional structuring methodology (Dreier-Alexy model), which divides the dogmatic study in analitical, empirical and normative areas. The argumentative itinerary of this investigation is given in three axes: the elaboration of a normative outline regarding public budget that serves as correction pattern of state conduct in budget cycle; the coeherence check of Supremo Tribunal Federal (Brazilian Supreme Federal Court) precedents concerning the abstract judicial review of budgetary norms; and the extraction of decisive standards relative to the financial phenomenon studied, in order to lately proposition of diagnosis about the interaction of political actors involved in the underlying reality of the research theme. It is concluded that the distortion of the constitutional order in the investigated scope serves as an institutional advantage in favor of the President in the budgeting process in the braziliam presidential system.
\end{abstract}

Key-words. Public Budget. Extraordinary Credits. Separation of Powers. 


\section{LISTA DE ILUSTRAÇÕES}

Quadro 1 - Dimensões e indicadores da AERD.

Quadro 2 - Narrativa jurisprudencial sobre o cabimento de ADI em face de lei orçamentária.

Quadro 3 - Abertura de créditos extraordinários por MP em função do exercício financeiro.

Quadro 4 - Visão global da ADI-MC 4.048

Quadro 5 - Lista de Medidas Provisórias que abrem créditos extraordinários editados no período de 2008 a 2015.

Quadro 6 - Lista de Ações Diretas de Inconstitucionalidade ajuizadas em face de Medidas Provisórias cujos objetos sejam a abertura de créditos extraordinários 


\section{LISTA DE TABELAS}

Tabela 1 - Despesa primária em educação do Governo Federal como proporção da receita líquida (\%).

Tabela 2 - Incidência de indicadores retóricos por Ministro. 


\section{LISTA DE ABREVIATURAS E SIGLAS}

Ação Direta de Inconstitucionalidade - ADI

Ação Declaratória de Constitucionalidade - ADC

Advocacia-Geral da União ou Advogado-Geral da União - AGU

Agravo Regimental - AgR

Análise Empírico-Retórica do Discurso - AERD

Arguição de Descumprimento de Preceito Fundamental - ADPF

Assembleia Nacional Constituinte - ANC

Ato das Disposições Constitucionais Transitórias - ADCT

Comissão Mista de Planos, Orçamento Público e Fiscalização - CMO

Congresso Nacional - CN

Constituição da República Federativa do Brasil de 1988 - CR/88

Decreto-Lei - DL

Diário de Justiça do Supremo Tribunal Federal - DJ

Diário de Justiça Eletrônico do Supremo Tribunal Federal - DJe

Embargos Declaratórios - ED

Emenda Constitucional - EC

Ethos - E

Fundo de Financiamento ao estudante do Ensino Superior ou Fundo de Financiamento Estudantil - FIES

Lei de Diretrizes Orçamentárias - LDO

Lei Orçamentária Anual - LOA

Lei de Responsabilidade Fiscal - LRF

Logos - L

Medida Cautelar - MC

Medida Provisória - MP

Pathos - P

Plano Plurianual - PPA

Presidência da República ou Presidente da República - PR

Procuradoria-Geral da República ou Procurador-Geral da República - PGR

Produto Interno Bruto - PIB

Programa Nacional de Acesso ao ensino Técnico e Emprego - Pronatec 
Proposta de Emenda à Constituição - PEC

Questão de Ordem - QO

Recurso Extraordinário - RE

Regimento Interno do Supremo Tribunal Federal - RISTF

Repercussão Geral - RG

Supremo Tribunal Federal - STF

Vice-Presidência ou Vice-Presidente - VP 


\section{SUMÁRIO}

INTRODUÇÃO.

1. O ORÇAMENTO PÚBLICO NA CONSTITUIÇÃO DA REPÚBLICA DE 1988.

2. A JURISDIÇÃO CONSTITUCIONAL E A JUSTICIABILIDADE EM ABSTRATO DAS DECISÕES ORÇAMENTÁRIAS.

3. O ORÇAMENTO PÚBLICO E A ABERTURA DE CRÉDITOS EXTRAORDINÁRIOS POR MEDIDA PROVISÓRIA.

CONCLUSÃO 160

REFERÊNCIAS BIBLIOGRÁFICAS

\section{ANEXOS}

A - Ementa, Acórdão e Extrato de Ata da ADI-MC 4.048. 186

B - Visão Global da ADI-MC e Incidência de indicadores retóricos...... 189

C - Lista de Medidas Provisórias que Abrem Créditos Extraordinários 192

D - Ações Diretas de Inconstitucionalidade Ajuizadas em face de Medida Provisória que Veicule Abertura de Crédito Extraordinário. .203 


\section{INTRODUÇÃO}

No uso da atribuição que lhe confere os artigos 62 e 167, §3º da Constituição da República de $1988^{1}$, a Presidente da República Dilma Vana Rousseff editou a Medida Provisória 711, de 18 de janeiro de 2016, com a finalidade de abrir crédito extraordinário no valor de $\mathrm{R} \$ 419.460 .681,00$ (quatrocentos e dezenove milhões, quatrocentos e sessenta mil, seiscentos e oitenta e um reais), em favor de diversos órgãos dos Poderes Legislativo e Judiciário, da Defensoria Pública da União e do Ministério Público da União ${ }^{2}$. Tratou-se de rubricas no orçamento fiscal da União para o exercício financeiro de 2016 com vistas precipuamente ao pagamento de ajuda de custo para moradia e auxílio-moradia a agentes públicos integrantes das precitadas entidades.

A despeito da própria temática do pagamento de verbas indenizatórias para fins de custeio de moradia a servidores públicos sujeitos ao regime de subsídios ser controversa e indeterminada na seara jurídico-política, a julgar pelas múltiplas manifestações, contra ou favor, nos mais diversos meios midiáticos, doutrinários e jurisprudenciais, chama atenção o instrumento orçamentário utilizado para satisfazer a referida necessidade pública, porquanto a $\mathrm{CR} / 88$ é expressa ao limitar as hipóteses de abertura de crédito extraordinário por MP às despesas públicas de índole imprevisível e urgente.

Ocorre que a imprevisibilidade dessa despesa corrente é pouco sustentável a partir da conjuntura social e política do país na medida em que a própria LDO de $2016^{3}$, tal como aprovada pelo CN e sancionada pela PR há menos de um mês da edição da MP 711/2016, no bojo de seu $\S 9^{\circ}$ do art. $17^{4}$ dispõe e restringe os casos nos quais o auxílio-moradia a agentes

\footnotetext{
1 “Art. 62. Em caso de relevância e urgência, o Presidente da República poderá adotar medidas provisórias, com força de lei, devendo submetê-las de imediato ao Congresso Nacional.”; e "Art. 167. São vedados: [...]§ $3^{\circ} \mathrm{A}$ abertura de crédito extraordinário somente será admitida para atender a despesas imprevisíveis e urgentes, como as decorrentes de guerra, comoção interna ou calamidade pública, observado o disposto no art. 62."

2 BRASIL. PRESIDÊNCIA DA REPÚBLICA. Medida Provisória 711, de 18 de janeiro de 2016. Abre crédito extraordinário, em favor de diversos órgãos dos Poderes Legislativo e Judiciário, da Defensoria Pública da União e do Ministério Público da União, no valor de R\$ 419.460.681,00, para os fins que especifica. Diário Oficial da União, Brasília, seção 1, publicado em 19.01.2016, p. 1.

${ }^{3}$ BRASIL. PRESIDÊNCIA DA REPÚBLICA. Lei 13.242, de 30 de dezembro de 2015. Dispõe sobre as diretrizes para a elaboração e execução da lei orçamentária de 2016 e dá outras providências. Diário Oficial da União, Brasília, seção 1, edição extra, publicado em 31.12.2015, p. 3.

4 "§ 9ํㅡㄹ Até que lei específica disponha sobre valores e critérios de concessão, o pagamento de ajuda de custo para moradia ou auxílio moradia, a qualquer agente público, servidor ou membro dos Poderes, do Ministério Público da União e da Defensoria Pública da União fica condicionado ao atendimento cumulativo das seguintes condições, além de outras estabelecidas em lei: I - não exista imóvel funcional disponível para uso pelo agente público; II - o cônjuge ou companheiro, ou qualquer outra pessoa que resida com o agente público, não ocupe imóvel funcional nem receba ajuda de custo para moradia ou auxílio moradia; III - o agente público ou seu
} 
públicos é devido. Em suma, torna-se forte a hipótese de que o Poder Executivo incorreu em acachapante inconstitucionalidade ao editar a MP supracitada.

Igualmente, o Supremo Tribunal Federal reputou inconstitucionais duas MPs por ofensa aos artigos 62 e 167, $\S 3^{\circ}$, da CR/88, nas medidas cautelares em ADI $4.048^{5}$ e $4.049^{6}$, de relatorias dos Ministros Gilmar Mendes e Ayres Britto, respectivamente, em julgamentos sucessivos no ano forense de 2008. Na visão majoritária dos integrantes da Corte, a abertura de crédito extraordinário para pagamento de despesas de custeio não se caracteriza pela imprevisibilidade e urgência.

Em 30 de abril de 2016, o Ministro Gilmar Mendes deferiu parcialmente medida cautelar na ADI 5.513 ajuizada pela agremiação política Solidariedade em decisão monocrática, ad referendum do Tribunal Pleno, conforme o art. 21, V, do RISTF, para fins de suspender a vigência da MP 722, de 28 de abril de 2016, ${ }^{7}$ na parte em que abre crédito extraordinário em favor da Presidência da República, sob as rubricas "Comunicação Institucional" (R \$ 85.000.000,00) e "Publicidade de Utilidade Pública" (R \$ 15.000.000,00). ${ }^{8}$

Cotejadas essas notícias, para além do lapso temporal de oito anos, sugere-se haver, no mínimo, uma divergência entre os Poderes acerca da interpretação constitucional a ser dada aos dispositivos precitados. Ao fim e ao cabo, pode-se haurir dessa problemática um quadro de reiterada violação à ordem constitucional, uma vez constatada a institucionalização de uma prática inconstitucional em campo orçamentário.

Nesse plano, o presente trabalho se propõe a abordar o seguinte problema: houve uma ofensa sistemática à Constituição Financeira, em decorrência da utilização reiterada de créditos extraordinários no âmbito federal, no período de 2008 a 2015 ?

cônjuge ou companheiro não seja ou tenha sido proprietário, promitente comprador, cessionário ou promitente cessionário de imóvel no Município aonde for exercer o cargo, incluída a hipótese de lote edificado sem averbação de construção, nos doze meses que antecederem a sua mudança de lotação; IV - o agente público deve encontrar-se no exercício de suas atribuições em localidade diversa de sua lotação original; V - a indenização destinar-se-á exclusivamente ao ressarcimento de despesas comprovadamente realizadas com aluguel de moradia ou com meio de hospedagem administrado por empresa hoteleira; e VI - natureza temporária, caracterizada pelo exercício de mandato ou pelo desempenho de ação específica."

${ }^{5}$ BRASIL. SUPREMO TRIBUNAL FEDERAL. Medida Cautelar na Ação Direta de Inconstitucionalidade 4.048, Plenário, Rel. Min. Gilmar Mendes, j. 14.05.2008, Publ. DJe 157, em 22.08.2008, pp. 55-192.

${ }^{6}$ BRASIL. SUPREMO TRIBUNAL FEDERAL. Medida Cautelar na Ação Direta de Inconstitucionalidade 4.049, Plenário, Rel. Min. Ayres Britto, j. 05.11.2008, Publ. DJe 84, em 08.05.2009, pp. 187-259.

${ }^{7}$ BRASIL. PRESIDÊNCIA DA REPÚBLICA. Medida Provisória 722, de 28 de abril de 2016. Abre crédito extraordinário, em favor da Presidência da República e do Ministério do Esporte, no valor de R\$ 180.000.000,00, para os fins que especifica. Diário Oficial da União, Brasília, Seção 1, edição extra, Publ. em 28.04.2016, p. 1.

${ }^{8}$ BRASIL. SUPREMO TRIBUNAL FEDERAL. Medida Cautelar na Ação Direta de Inconstitucionalidade 5.513, decisão monocrática, Rel. Min. Gilmar Mendes, j. 30.04.2016, Publ. DJe 89, em 04.05.2016, p. 1. 
A partir de um levantamento prévio das MPs do período selecionado e da literatura jurídica referente à doutrina ${ }^{9}$, lança-se uma hipótese afirmativa, segundo a qual o manejo do orçamento público opera em uma espécie de emergência programada, tendo em vista a periodicidade e o volume de créditos extraordinários abertos pela via das medidas provisórias com relação ao planejamento orçamentário globalmente considerado.

Do mesmo modo, elegem-se os seguintes problemas secundários, para os quais também se apresentam hipóteses afirmativas a serem verificadas:

(i) Há um perfil normativo referente ao orçamento público, à luz da Constituição Financeira, passível de utilização como parâmetro de correção material da conduta estatal no ciclo orçamentário, notadamente na instrumentalização das medidas provisórias as quais abrem créditos extraordinários?

(ii) A construção jurisprudencial do Supremo Tribunal Federal acerca do controle abstrato de constitucionalidade de normas orçamentárias na atual ordem constitucional se mostrou coerente e adequada em nível argumentativo?

Justifica-se a escolha e relevância deste objeto de trabalho, ao fundamento de potencial tensão no constitucionalismo financeiro, aferido o abuso do expediente dos créditos extraordinários no manejo do orçamento público. Sendo assim, o fenômeno financeiro descrito tem repercussões jurídicas, políticas e econômicas em níveis constitucional e democrático, pois se colocam em questão as condições de possibilidade de planejamento, transparência, controle e responsabilização da atividade financeira do Estado brasileiro.

Ademais, a conflituosa interação entre os Poderes da União acerca da interpretação da $\mathrm{CR} / 88$ imputa densidade jurídico-política ao problema posto, porquanto o estado da arte dos freios e contrapesos institucionais em matéria orçamentária apresenta efetivo impacto na dinâmica de fruição de direitos fundamentais, haja vista a politização das competências e decisões sobre a alocação de recursos públicos.

Nesse sentido, reputa-se imperativo um olhar cuidadoso por parte de uma dogmática jurídica comprometida com a concretização de direitos fundamentais em relação ao financiamento das despesas públicas.

\footnotetext{
${ }^{9}$ Cf. PASSEROTTI, Denis Camargo. O Uso das Medidas Provisórias para Instituição de Créditos Adicionais Extraordinários e o Orçamento Público. In: Revista Fórum de Direito Financeiro e Econômico, Belo Horizonte, ano 3, n. 5, mar./ago. de 2014, pp. 17-132; BARRETTO, Érica de Santana Silva. Os Créditos Adicionais e sua Excessiva Utilização pelo Poder Executivo Federal. In: Revista Fórum de Direito Financeiro e Econômico, Belo Horizonte, ano 4, n. 6, set./fev. 2015, pp. 79-92.
} 
A partir desse prisma, adentra-se nos objetivos da presente pesquisa, na qualidade de contributo acadêmico, passíveis de sistematização em duas dimensões. Por um lado, busca-se evidenciar e combater uma assimetria constitucional entre gastos e recursos públicos com significativos reflexos na agenda do país. ${ }^{10}$

Noutra banda, incorpora-se como premissa um descuido teórico sistêmico em âmbito latino-americano consistente em priorizar reformas constitucionais que tragam em seu bojo a positivação de direitos sociais, econômicos e culturais, os quais dependem, por sua vez, de volumosos recursos públicos para respectiva concretização na realidade social, em detrimento de modificações estruturais na organização política do Estado ("Sala de Máquinas da Constituição"). ${ }^{11}$ Por conseguinte, esse estudo intentará repensar sobre os modos em que se desenvolve a Constituição Financeira, sobretudo na dinâmica de freios e contrapesos institucionais no âmbito do ciclo orçamentário.

Importa, ainda, tecer comentário a respeito do recorte metodológico a que se propõe esta pesquisa. A propósito, atribui-se ao Direito Financeiro certa autonomia e especialidade. A especialização desse ramo jurídico ocorre por se ocupar da atividade financeira do Estado. Por outro lado, a autonomia, como efeito da especialização deve ser entendida com algum grau de relatividade, porque quer dizer apenas a construção, estudo e explicação dogmática de um setor do ordenamento jurídico. ${ }^{12}$

Para além do objeto de trabalho, qual seja, conjunto de dados primários e secundários, normativos e empíricos, acerca dos créditos extraordinários, o período temporal compreendido de 2008 a 2015 se baseia na vigência de dois planos plurianuais e no fato dos julgamentos das AADDI 4.048 e 4.049 terem se dado no ano-base inicial, o que permite explicitar o grau de observância às razões de decidir expendidas pelo STF.

Ainda na seara metodológica, adota-se uma concepção epistemológica da dogmática jurídica que se adjetiva como "inclusiva", pois pressupõe "uma multiplicidade de perspectivas de estudo do direito, quando da elaboração de respostas aos problemas colocados, às quais se possa associar o atributo da cientificidade, compatível com o caráter prático desses problemas

\footnotetext{
10 Trata-se de premissa teórica inspirada no pensamento de Horacio Guillermo Corti articulado no contexto argentino, mas plenamente aplicável à realidade brasileira, dada a similitude da formação histórico-política das finanças públicas de ambos os países em contexto latino-americano: CORTI, Horacio Guillermo. Derecho Financiero. Buenos Aires: Abeledo-Perrot, 1997, pp. 76-83.

${ }^{11}$ GARGARELLA, Roberto. La Sala de Máquinas de la Constitución: dos siglos de constitucionalismo en América Latina (1810-2010). Buenos Aires: Katz, 2014, p. 7.

12 LAPATZA, José Juan Ferreiro. Curso de Derecho Financiero Español: instituciones. 25 ed. Madri-ES: Marcial Pons, 2006, pp. 32-35.
} 
e, por via de consequência, também da ciência que deles se ocupe."13

Assim sendo, o parâmetro a ser seguido é o proposto pela metodologia tridimensional estruturante, tal como formulada por Ralf Dreier ${ }^{14}$ e Robert Alexy (Modelo Dreier-Alexy), divisando o estudo dogmático do direito nas dimensões analítica, empírica e normativa. ${ }^{15}$

A perspectiva analítica diz respeito à dissecação sistemático-conceitual do direito vigente, desde categorias basilares à própria estrutura do sistema jurídico. No viés empírico, pode-se falar tanto da cognição do direto positivo válido, quanto da aplicação de premissas empíricas na argumentação jurídica. Por fim, a dimensão normativa se traduz na avaliação crítica da práxis jurídica, especialmente jurisprudencial. ${ }^{16}$

Segundo Alexy, a ciência jurídica "deve ser uma disciplina integradora e multidimensional: combinar as três dimensões é uma condição necessária da racionalidade da ciência jurídica como disciplina prática." ${ }^{17}$

Igualmente, adota-se um ideário legatário da tradição aristotélica, pois, para esse filósofo, a razão de ser das constituições dos antigos (formas de governo) é a institucionalização de um critério de justiça sob a forma da igualdade, porém essa instituição tende a falhar na discordância, em concreto, acerca da configuração dessa isonomia. Desse insucesso decorre a origem das revoluções ${ }^{18}$ como resultantes do facciosismo, por sua vez criado pelas desigualdades e pelo desejo de igualdade ${ }^{19}$. De modo semelhante a Aristóteles, preocupa-se com a salvaguarda da estrutura política por meio das instituições e do

\footnotetext{
${ }^{13}$ GUERRA FILHO, Willis Santiago. Processo Constitucional e Direitos Fundamentais. 2 ed. São Paulo: Celso Bastos Editor/Instituto Brasileiro de Direito Constitucional, 2001, pp. 32-33.

${ }^{14}$ Cf. DREIER, Ralf. Concepto y Función de la Teoría General del Derecho. In: Revista de la Facultad de Derecho de la Universidad Complutense, Madri-ES, Nueva Época, n. 52, 1978, pp. 111-138.

15 "A aplicação de normas constitucionais implica uma dogmática jurídica. A dogmática jurídica concebe-se como uma disciplina pluridimensional (Alexy) abrangendo três actividades básicas: (1) descrição do direito vigente; (2) análise sistemática e conceitual deste direito; (3) elaboração de propostas de solução de casos jurídicos problemáticos. Há, assim, na actividade interpretativa-aplicativa de normas constitucionais, uma dimensão teórico-descritiva e prático-normativa." (CANOTILHO, J. J. Gomes. Direito Constitucional e Teoria da Constituição. 7 ed. Coimbra: Almedina, 2003, p. 1118, grifos no original)

${ }^{16}$ ALEXY, Robert. Teoria dos Direitos Fundamentais. Trad. Virgílio Afonso da Silva. São Paulo: Malheiros, 2008, pp. 33-36.

${ }^{17}$ ALEXY, Robert. Teoria dos Direitos Fundamentais. Trad. Virgílio Afonso da Silva. São Paulo: Malheiros, 2008, p. 37.

${ }^{18}$ Nesse ponto, a expressão possui uma acepção eminentemente destrutiva da vida gregária, como sói típica na tradição greco-romana: "Resta-nos indagar agora qual é o número e qual a natureza das causas de revoluções nas cidades, quais os modos de destruição inerentes a cada forma de governo, quais as formas que os governos abandonam e quais as que eles adotam quando mudam, quais as salvaguardas das constituições em geral e de cada forma em particular, e quais os meios a que se deve recorrer para salvaguardar cada forma de governo." (ARISTÓTELES. Política. Trad. Mário da Gama Kury. Brasília: Universidade de Brasília, 1985, p. 161)

${ }^{19}$ ARISTÓTELES. Política. Trad. Mário da Gama Kury. Brasília: Universidade de Brasília, 1985, pp. 161-162.
} 
$\operatorname{argumento}^{20}$ na esfera contingencial do humano ${ }^{21}$. Postulação da qual se compartilha para os fins desta pesquisa, na medida em que guiará o expediente argumentativo aqui proposto, como se passa a explanar.

Na primeira parte da investigação, as dimensões analítica e empírica da metodologia precitada serão abordadas com referencial no Orçamento Público. Nesse ensejo, serão lançadas as bases conceituais ${ }^{22}$ acerca do fenômeno financeiro em seu aspecto jurídico para o exame mais detido dos créditos adicionais extraordinários nas seções posteriores. Haverá, portanto, priorização temática à constitucionalização do Direito Financeiro e ao arcabouço conceitual estruturante do sistema orçamentário nacional.

Após, a dimensão normativa se explicitará, haja vista que se pretende uma análise e avaliação da práxis jurisprudencial do STF relativamente ao controle abstrato de normas orçamentárias. Tem-se o intuito de investigar se é possível extrair dos precedentes judiciais razões de decidir coerentes e coesas para a regulação da conduta estatal, principalmente a partir da evolução jurisprudencial quanto ao tema. Importa, ainda, constatar criticamente o grau de vinculatividade das decisões a serem perqueridas ${ }^{23}$.

$\mathrm{Na}$ qualidade de técnica conectiva entre os procedimentos e a vertente metodológica da pesquisa, a estratégia adotada é a análise de conteúdo, operacionalizada pelo exame conjectural e de conteúdo da ADI-MC 4.048, de relatoria do Ministro Gilmar Mendes. Assim, a análise de discurso como abordagem de estudo de textos se insere na tradição científica como crítica ao modo tradicional de fazer ciência social, tendo em conta que a base epistemológica daquela é o construtivismo social.

Nesse ponto, lança-se mão do aporte tópico desenvolvido por Theodor Viehweg e decorrentes teorias da argumentação jurídica, especialmente a retórica moderna da Escola de Mainz e a teoria da argumentação jurídica standard pautada na obra de Neil MacCormick.

\footnotetext{
${ }^{20}$ Verifica-se, a propósito, que nos estudos de Aristóteles sobre a elaboração do discurso, formado pela arte retórica e pela arte poética, um dos cinco temas mais importantes da deliberação da retórica de tipo deliberativo é justamente as Finanças. Cf. ARISTÓTELES. Retórica. 2 ed. Trad. Manuel Alexandre Júnior, Paulo Farmhouse Alberto e Abel do Nascimento Pena. Lisboa: Imprensa Nacional-Casa da Moeda, 2005, p. 107.

${ }^{21}$ ARISTÓTELES. Política. Trad. Mário da Gama Kury. Brasília: Universidade de Brasília, 1985, pp. 183 e ss.

${ }^{22}$ Segundo as professoras Miracy Barbosa de Sousa Gustin e Maria Tereza Fonseca Dias, a análise de conteúdo, como um grupo de estratégias metodológicas de cunho qualitativo, pressupõe condições próprias: "A análise de conteúdo não tem motivações históricas, mesmo que os dados e informações pertençam ao passado, são inseridos pelo analista em novo contexto, com objetivos e objeto próprio de pesquisa. Um sistema de conceitos analíticos é construído para servir como um sistema de referências conceituais que realizarão as inferências, próprias dessa técnica." (GUSTIN, Miracy Barbosa de Sousa; DIAS Maria Tereza Fonseca. (Re)pensando a Pesquisa Jurídica: teoria e prática. Belo Horizonte: Del Rey, 2002, p. 111)

${ }^{23}$ Cf. WAMBIER, Teresa Arruda Alvim. A Vinculatividade dos Precedentes e o Ativismo Judicial: paradoxo apenas aparente. In: DIDIER JUNIOR, Fredie; et al. (orgs.). Precedentes. Salvador: Juspodivm, 2015.
} 
Em um terceiro momento, volta-se à dimensão empírica da dogmática jurídica, porquanto se propõe percorrer todas as medidas provisórias editadas na esfera federal entre 2008 e 2015 que versem sobre a abertura de créditos extraordinários, assim como seus respectivos processos legislativos. Dessa análise, espera-se extrair padrões decisórios institucionais e cognitivos relacionados ao fenômeno financeiro estudado em seus aspectos jurídicos, econômicos e políticos, com vistas a elucidar os problemas supracitados desta investigação científica.

Em perspectiva prático-normativa, haverá proposições de diagnósticos para o aprimoramento do estado de coisas em relação a eventuais inadequações em nível de constitucionalismo democrático, notadamente no que tange às conversações públicas entre os atores institucionais envolvidos na realidade social subjacente ao objeto de estudo. 


\section{O ORÇAMENTO PÚBLICO NA CONSTITUIÇÃO DA REPÚBLICA DE 1988}

O presente capítulo tem por objeto responder se há um perfil normativo referente ao orçamento público, em plano constitucional, passível de utilização como parâmetro de correção material da conduta estatal no ciclo orçamentário, notadamente na instrumentalização das MPs que abrem créditos adicionais extraordinários.

Por um lado, para avaliar a adequabilidade constitucional e democrática da fundamentação de uma decisão judicial, à luz das teorias da argumentação jurídica, faz-se necessário perquirir a discussão jurídica relativa ao caso concreto.

Noutra banda, a concretização do princípio da separação dos poderes exige uma visão mais ampla e interdisciplinar da atividade financeira do Estado, tendo em conta uma dinâmica conflitiva de freios e contrapesos entre os Poderes, uma vez que está em jogo a disputabilidade dos significados das normas constitucionais. Logo, o enfoque é distinto do observado na ANC de 1987/1988, quando se disputava o significante, o signo linguístico, o texto da CR/88.

Nesse sentido, busca-se percorrer o seguinte itinerário argumentativo neste capítulo. Em primeiro momento, pretende-se abordar a dimensão financeira de um Estado Constitucional, a partir de uma definição específica, abarcando as categorias financeiras referentes ao Estado Fiscal, governança republicana, federalismo fiscal, soberania fiscal e Constituição Financeira.

Após, haverá articulação discursiva no sentido de avaliar a tensão entre constitucionalismo e democracia na realidade financeira brasileira na atual ordem constitucional. Nesse sentido, uma introdução aos aspectos financeiros da cidadania, democracia, separação dos poderes e direitos fundamentais será realizada.

Enfim, será discutida uma concepção de orçamento público extraída da CR/88 e respectivos debates no âmbito da Assembleia Nacional Constituinte de 1987 e 1988; assim a linha de raciocínio partirá desde os princípios à natureza jurídica das leis orçamentárias.

\subsection{A Dimensão Financeira do Estado Constitucional}


Observa-se na modernidade uma diferenciação funcional entre o Direito e a Política, de modo que a complementaridade entre o jurídico e o estatal tem matriz contingencial. Segundo Neil MacCormick, o Estado territorial é uma entidade primariamente política, caracterizada pela territorialidade e a estabilidade do governo, este efetivamente exercido em face da população, por sua vez composta majoritariamente por cidadãos. Ademais, nota-se o desenvolvimento de uma consciência comum acerca da nacionalidade compartilhada. ${ }^{24}$

Entendido o Direito como ordem normativa institucional, observa-se que as esferas jurídica e estatal relacionam-se de diversas formas ${ }^{25}$, a depender da concretude histórica de uma sociedade. Mais importante para a presente pesquisa e com o ganho de importância jurídico-política das Constituições modernas, sendo estas molduras legais aos Estados, ressaltam-se as cinco características essenciais de um Estado Constitucional: (i) a territorialidade, que se traduz no efetivo controle em território específico, fazendo uso, inclusive, de força coercitiva com relação às ameaças interna e externa; (ii) a legitimidade, quando o efetivo controle se realiza devidamente pela autoridade sobre o território; (iii) a independência, na medida em que a autoridade governamental é exercida livre de interferência externa de outros estados; (iv) o reconhecimento e a efetividade de um governo aos olhos dos demais estados, com base no princípio da não-interferência mútua; e (v) uma constituição funcional que estabelece instituições de direito público. ${ }^{26}$

Nesse quadro, pretende-se abordar pontualmente os referidos itens, especificamente no que tange à dimensão financeira dessas características. Em relação à legitimidade, busca-se lançar as premissas teórico-compreensivas à formação do Estado fiscal brasileiro e a governança republicana das verbas públicas. Já sobre o território, a temática do federalismo fiscal será pautada. Após, a independência e a efetividade do governo serão abordadas em conjunto ao tratar de soberania fiscal. Ao fim, a discussão constitucional se centrará na teoria

\footnotetext{
${ }^{24}$ MACCORMICK, Neil. Questioning Sovereignty: law, state, and nation in the European Commonwealth. Nova York: Oxford University Press, 1999, p. 17.

${ }^{25}$ Para MacCormick, há basicamente quatro modelos de entrelaçamento: o Estado dependente do Direito (direito natural de cunho teológico); o Direito dependente do Estado (jusracionalismo contratualista); a coexistência entre o Direito e o Estado (não há monopólio das fontes jurídicas pelo Estado, uma vez que o Direito é uma forma de ordem normativa consuetudinária, de modo que o jurídico e o governamental são vistos como sistemas históricos co-evolutivos); e a identidade entre o Estado e o Direito (positivismo normativista). Por fim, identifica a atual quadra histórica como uma identidade imperfeita entre o Direito e o Estado (MACCORMICK, Neil. Questioning Sovereignty: law, state, and nation in the European Commonwealth. Nova York: Oxford University Press, 1999, pp. 17-26, grifos no original).

${ }^{26}$ MACCORMICK, Neil. Institutions of Law: an essay in legal theory. Nova York: Oxford University Press, 2007, pp. 39-49.
} 
da Constituição Financeira.

\subsubsection{Estado fiscal e república}

A dinâmica de afirmação do poder econômico-financeiro do Estado territorial é historicamente conflituosa, especialmente em decorrência da centralização de responsabilidades e poderes nas mãos estatais, ao passo que houve uma transformação do status do corpo popular de súditos para cidadãos, o que, por evidente, tem reflexos na seara da atividade financeira do Estado.

No pensamento de Thomas Nagel e Liam Murphy, o problema da legitimidade política se define em dois eixos: (i) aquilo que devemos aos nossos concidadãos; e (ii) a soberania que podemos conservar sobre a nossa própria pessoa, livres da autoridade do Estado, mesmo sendo membros dele e estando sujeitos ao seu controle em certos aspectos. ${ }^{27}$

Nesse aspecto, tem-se o tributo como uma das inovações com maior aptidão para redução das desigualdades jurídicas, políticas e econômicas no bojo da comunidade política, uma vez que se torna o instrumento mais importante por meio do qual o sistema político concretiza uma concepção histórica de justiça econômica. ${ }^{28}$ Logo, a axiologia da tributação reside na esfera pública em que se delibera e se decide sobre a arrecadação, gestão e despesa de verbas públicas.

Noutras palavras, a questão da legitimidade política no âmbito do sistema tributário ${ }^{29}$ se traduz na estrutura social dentro da qual os cidadãos consideram moralmente aceitável viver, à luz de valores compartilhados como os da liberdade, responsabilidade, igualdade, eficiência e bem estar. ${ }^{30}$

Assim sendo, revela-se interessante a constatação de Thomas Pikkety de que a

\footnotetext{
${ }^{27}$ MURPHY, Liam; NAGEL, Thomas. O mito da propriedade: os impostos e a justiça. Trad. Marcelo Brandão Cipolla. São Paulo: Martins Fontes, 2005, p. 56.

${ }^{28}$ MURPHY, Liam; NAGEL, Thomas. O mito da propriedade: os impostos e a justiça. Trad. Marcelo Brandão Cipolla. São Paulo: Martins Fontes, 2005, p. 5.

${ }^{29}$ Nos termos do presente trabalho, sistema tributário é definido como "a reunião de um conjunto de impostos, taxas e contribuições através dos quais o Estado obtém recursos para o exercício das suas funções básicas, como a oferta de bens e serviços essenciais para o bem-estar da coletividade" (CONSELHO DE DESENVOLVIMENTO ECONÔMICO E SOCIAL. Indicadores de Iniquidade do Sistema Tributário Nacional: Relatório de Observação no 2. 2. ed. Brasília: Presidência da República, 2011, p. 17).

${ }^{30}$ MURPHY, Liam; NAGEL, Thomas. O mito da propriedade: os impostos e a justiça. Trad. Marcelo Brandão Cipolla. São Paulo: Martins Fontes, 2005, p. 57.
} 
tributação não é uma questão técnica, mas, precipuamente, um assunto filosófico e político, pois a sociedade não possuiria destino comum e a ação coletiva seria impossível. Para o economista francês, não há dúvida de que no cerne de toda grande questão política reside uma revolução fiscal. ${ }^{31}$

Nesses termos, a tributação tem um valor social notadamente instrumental, porquanto a avaliação do sistema tributário depende da forma como os tributos são coletados e de que forma eles são usados. Demais, política e tributação convergem no conceito de matriz tributária, definível como "as escolhas feitas em um determinado momento histórico no campo das ações sociais, no que diz respeito ao fenômeno tributário". ${ }^{32}$

Retornando-se ao relacionamento entre Estado Fiscal e cidadania, percebe-se a inviabilidade atual de uma perspectiva de separação estrita entre sociedade civil e Estado, tendo em conta que essas instituições estão imbricadas na noção de liberdade fiscal. ${ }^{33}$ Se de um lado concebe-se um dever fundamental de pagar impostos referenciado a toda sociedade de suportar os custos financeiros do Estado $^{34}$; de outro lado é o bem-estar do cidadão que justifica a própria existência do sistema tributário, ${ }^{35}$ à luz do princípio da capacidade contributiva. ${ }^{36}$

Dentro desse contexto, o Estado territorial exibe uma dimensão financeira relacionada às atividades das finanças públicas. Trata-se do que genericamente chama-se de Estado Financeiro, por sua vez divisível, em termos históricos e comparados, de acordo com a origem precípua de suas rendas, em Estado Patrimonial, Estado de Polícia, Estado Fiscal e Estado

\footnotetext{
${ }^{31}$ PIKKETY, Thomas. Capital in the Twenty-First Century. Trad. Arthur Goldhammer. Cambrigde-EUA: The Belknap Press of Harvard University Press, 2014, p. 493.

32 GASSEN, Valcir. Matriz Tributária brasileira: uma perspectiva para pensar o Estado, a Constituição e a Tributação no Brasil. In: GASSEN, Valcir. Equidade e Eficiência da Matriz Tributária Brasileira: Diálogos sobre Estado, Constituição e Direito Tributário. Brasília: Consulex, 2012, p. 32.

33 "Liberdade e tributo, conseguintemente, caminham juntos no decurso da evolução do Estado financeira, pelo que se pode cogitar de uma liberdade fiscal: o tributo nasce no espaço aberto pela autolimitação da liberdade, constitui o preço da liberdade, pois é o instrumento que distancia o homem do Estado, e pode implicar na opressão da liberdade, se o não contiver a legalidade. O relacionamento entre liberdade e tributo é dramático, pois vive sob o signo da bipolaridade: o tributo é garantia da liberdade e, ao mesmo tempo, possui extraordinária aptidão para destruí-la; a liberdade se autolimita para se assumir como fiscalidade e se revolta, rompendo os laços da legalidade, quando oprimida pelo tributo ilegítimo." (TORRES, Ricardo Lobo. A Idéia de Liberdade no Estado Patrimonial e no Estado Fiscal. Rio de Janeiro: Renovar, 1991, pp. 2-3)

${ }^{34}$ NABAIS, José Casalta. O Dever Fundamental de Pagar Impostos. Coimbra: Almedina, 1998, p. 186.

35 JUSTEN FILHO, Marçal. Sistema Constitucional Tributário: uma aproximação ideológica. In: Revista da Faculdade de Direito da UFPR, Curitiba, a. 30, n. 30, 1998, pp. 215-233, p. 221.

36 "Importa aos objetivos do presente trabalho enfatizar, uma vez mais, a visualização do princípio da capacidade contributiva na sua dimensão do princípio da solidariedade, do princípio republicano e do princípio da igualdade, o que significa vislumbrá-lo sob a ótica do dever imputado, como regra, a todos, de concorrer para a manutenção do Estado." (OLIVEIRA, Ricardo Rachid de. A Relevância Penal da Inadimplência Tributária. Curitiba: Juruá, 2013, p. 73)
} 
Socialista $^{37}$. Nesse ponto, revelam-se com maior capacidade explicativa os Estados Patrimonial e Fiscal, merecendo maior atenção doutrinária, na medida em que aquele extrai suas receitas do patrimônio estatal e este haure seus haveres do patrimônio do contribuinte ${ }^{38}$.

Aliás, a expressão "Estado Fiscal" surge da Economia do Setor Público, especificamente da célebre controvérsia entre Joseph Alois Schumpeter ${ }^{39}$ e Rudolf Goldscheid a respeito da crise do modelo estatal liberal e capitalista observado na Áustria em meados da Primeira Guerra Mundial ${ }^{40}$. Logo, a categoria surgiu para descrever o Estado financiado pelos tributos incidentes sobre os contribuintes e respectiva crise decorrente da saturação da carga tributária na lógica do liberalismo econômico, em contraposição ao Estado Patrimonial com a fonte principal de receitas oriunda de recursos naturais.

Nesse sentido, ambos os ideais de Estado remanescem hodiernos, a partir de constantes ressignificações conceituais, estruturais e conjecturais, porquanto não se observa na experiência comparada uma trajetória unidirecional voltada à transição de um tipo estatal para o outro. $^{41}$

No campo do Direito Financeiro, o léxico mostrou-se útil para a construção de uma tipologia estatal com fundamento no critério da natureza do vínculo que origina a receita pública, repercutindo na questão da legitimidade política supracitada. Assim, "Conceitua-se Estado Patrimonial aquele em que as receitas públicas são predominantemente extraídas da exploração de seu patrimônio (...) o que corresponde aos três setores básicos da atividade econômica". 42

Noutro giro, o Estado Fiscal é aquele que se sustenta predominantemente por meio da tributação, como poder de império. Nessa perspectiva, a atividade tributária se volta à realização da igualdade constitucional em uma dinâmica relacional entre os concidadãos, por

\footnotetext{
${ }^{37}$ TORRES, Ricardo Lobo. A Idéia de Liberdade no Estado Patrimonial e no Estado Fiscal. Rio de Janeiro: Renovar, 1991, p. 1.

${ }^{38}$ Para uma diferenciação entre cidadão e contribuinte, veja-se: SANTOS, António Carlos dos. Cidadania Europeia, Contribuinte europeu. Uma Relação com o Futuro? In: HORVARTH, Estevão; CONTI, José Maurício; SCAFF, Fernando Facury (orgs.). Direito Financeiro, Econômico e Tributário: estudos em homenagem a Regis Fernandes de Oliveira. São Paulo: Quartier Latin, 2014.

39 SCHUMPETER, Joseph A. The Economics and Sociology of Capitalism: the crisis of the tax state. In: BACKHAUS, Jürgen G. (ed.). Navies and State Formation: the schumpeter hypothesis revisited and reflected. Munique: LIT Verlag, 2012.

${ }^{40}$ MUSGRAVE, Richard A. Schumpeter's crisis of the Tax State: an essay in fiscal sociology. In: Journal of Evolutionary Economics, v. 2, n. 2, pp. 89-113.

${ }^{41}$ Cf. YUN-CASALILLA, Bartolomé; O'BRIEN, Patrick K (eds.). The Rise of Fiscal States: a global history 1500-1914. Nova York: Cambridge University Press, 2012.

${ }^{42}$ SCAFF, Fernando Facury. Royalties do Petróleo, Minério e Energia: aspectos constitucionais, financeiros e tributários. São Paulo: RT, 2014, p. 28.
} 
meio de duas funções principais: a repartição do sistema de propriedade entre o público e o privado; e a distribuição do produto social tanto sob a forma de propriedade privada quanto sob a forma de benefícios fornecidos pela ação pública. ${ }^{43}$

Enfim, a partir da aceleração do processo de globalização dos mercados e expansão do capital financeiro, nota-se o surgimento de um novo modelo estatal caracterizado pela intensificação do endividamento público. ${ }^{44}$ Ainda em sede de "sociologia físcal", a preponderância da utilização de crédito público como maneira de financiamento das atividades do Estado, em detrimento dos tributos, leva a um "Estado Endividado" no qual a sustentabilidade financeira torna-se uma preocupação séria e constante. ${ }^{45}$

$\mathrm{Na}$ realidade socioeconômica brasileira, percebe-se a produção contínua de déficits nominais, justificados em grande parte pelo aumento de despesas públicas em patamar superior à inflação e sem a necessária contrapartida relativa ao acréscimo de receitas. Nesse sentido, a fonte de financiamento do Estado parece migrar do tributo para o empréstimo público, colocando em questão a viabilidade da atividade financeira do Estado. ${ }^{46}$

Noutro giro, em relação à perspectiva republicana do Estado, verifica-se que a escolha da forma de governo possui claras repercussões financeiras e orçamentárias. A propósito, a pulverização de centros de poder gerou a inviabilidade prática de monopólios, inclusive jurídicos, de modo que a tônica da contemporaneidade é o pluralismo. Assim, a mantença do cidadão como titular da coisa pública, na qualidade de corolário do princípio republicano, gera desafios institucionais para a criação de uma gestão estatal orientada por valores cívicos.

Nesse contexto, mostra-se relevante o conceito de governança republicana, notadamente no campo das finanças públicas, traduzível em uma plêiade normativa e de

\footnotetext{
${ }^{43}$ MURPHY, Liam; NAGEL, Thomas. O mito da propriedade: os impostos e a justiça. Trad. Marcelo Brandão Cipolla. São Paulo: Martins Fontes, 2005, p. 101.

44 "A fórmula encontrada foi a da intensificação do endividamento público, através do qual se obtém recursos agora, para pagamento futuro. É em razão dessa troca entre gasto público atual, mediante recursos hauridos por empréstimos, e o comprometimento de renda futura para seu pagamento, que se costuma dizer que empréstimos são tributos antecipados, ou seja, comprometem os tributos que serão arrecadados pelas futuras gerações para pagamento dos gastos realizados pela atual geração. Isso ocorreu em todos os países da chamada civilização ocidental." (SCAFF, Fernando Facury. As Agruras do Homem no Estado Endividado. In: NUNES, António José Avelãs. Quo Vadis, Europa? São Paulo: Contracorrente, 2016, p. 10)

${ }^{45}$ Cf. SCAFF, Fernando Facury. Crédito Público e Sustentabilidade Financeira. In: Revista Fórum de Direito Financeiro e Econômico, Belo Horizonte, a. 3, n. 5, mar./ago. 2014, pp. 55-70.

46 "No Brasil, os tributos já foram, até bem pouco tempo, a principal fonte de receitas públicas. Atualmente, porém, a maior representatividade da arrecadação está nas receitas financeiras decorrentes das operações de crédito, chegando a ultrapassar $50 \%$ do orçamento. O restante, menos de $10 \%$ do total, decorre das receitas de natureza patrimonial, industrial, de serviços, alienação de bens etc.” (ABRAHAM, Marcus. Coluna Fiscal: do tributo ao crédito publico - uma nova realidade fiscal. In: Jota, Publ. 2 de junho de 2016. Disponível em: <http://jota.uol.com.br/coluna-fiscal-tributo-ao-credito-publico-uma-nova-realidade-fiscal>. Acesso em 04.06.2016)
} 
instrumentos gerenciais voltada à concretização de uma condução cidadã da atividade financeira do Estado, com o fito de promover direitos fundamentais, de forma transparente, monitorada e com efetiva participação social. ${ }^{47}$

Observa-se, portanto, a formulação de marcos institucionais por parte de organismos supranacionais (v.g. Modelo de Governança Fiscal da União Europeia) e internacionais (v.g. Modelo de Governança Orçamentária da OCDE), ao fundamento de persecução da eficiência do gasto público por meio da governança fiscal e orçamentária. ${ }^{48}$

Igualmente, revela-se desafiante o tema da dimensão orçamentária da cidadania participativa a qual se expressa por meio das previsões legais que permitem o conhecimento e envolvimento do cidadão nas deliberações acerca da arrecadação financeira e a realização de despesas públicas, assim como no acompanhamento da execução do orçamento público. ${ }^{49}$

Nesse sentido, o desafio reside em estimular o engajamento cívico em torno do orçamento público, de modo a legitimar democraticamente esse diploma legislativo como peça fundamental do planejamento e controle do destino compartilhado da comunidade republicana.

\subsubsection{Federalismo Fiscal}

O território pode ser definido como espaço jurídico próprio do Estado, de modo a atuar como limite ao poder político efetivo. Nesses termos, há uma relação imbricada entre a territorialidade, o poder e o Povo, uma vez que do primeiro se extrai a unidade jurídica da estatalidade, consistente na sujeição espacial dos titulares de direito ao mesmo poder e Direito. Logo, justamente dessa união entre Estado, povo e território advém a igualdade de direitos e deveres dos cidadãos integrantes da esfera pública. Ademais, conclui-se que "A configuração e a dimensão do território de qualquer Estado em concreto projectam-se, mais

\footnotetext{
${ }^{47}$ CAMARGO, Guilherme Bueno de. Governança Republicana como Vetor para a Interpretação das Normas de Direito Financeiro. 239 f. Tese de Doutorado - Faculdade de Direito, Universidade de São Paulo, São Paulo, 2010, pp. 70-71.

48 "Enquanto a primeira se ocupa de temas como equilíbrio das contas públicas, resultado fiscal, volume e trajetória da dívida pública, a segunda lida com questões como eficiência, eficácia e efetividade da ação governamental." (BIJOS, Paulo Roberto Simão. Governança Orçamentária: uma relevante agenda em ascensão. In: SENADO FEDERAL. Orçamento em discussão, Brasília, n. 12, 2014, p. 11)

49 ABRAHAM, Marcus. Orçamento Público como Instrumento de Cidadania Fiscal. In: Revista de Direitos Fundamentais e Democracia, Curitiba, v. 17, n. 17, jan./jun. 2015, pp. 188-209, pp. 193-194.
} 
ou menos directa e intensamente, na sua forma política."50

Ante a questão da organização territorial do Estado, resulta o federalismo como possível solução. Nos estudos de finanças públicas, o planejamento eficiente da política fiscal possui três objetivos basilares: a alocação de recursos; a distribuição de riquezas e rendas; e a estabilidade macroeconômica. ${ }^{51}$ Ao dispersar ou concentrar o poder político em unidades territoriais autônomas, escolhe-se o grau de compartilhamento e solidaderiedade na persecução dessas metas.

A esse respeito, o federalismo fiscal é um sistema que permite o rateio de verbas públicas no tempo e no espaço. Neste último, compartilham-se receitas, despesas e competências em eixos horizontal (entre governos locais) e vertical (entre o governo central e os governos locais), de forma geograficamente considerada. No critério temporal, projeta-se o uso das verbas públicas de maneira intergeracional. ${ }^{52}$

Aliás, a formação de um pacto federativo pressupõe a institucionalização de um critério de justiça, então a responsabilidade alocativa é atribuída, em regra, aos entes subnacionais na medida das respectivas autonomias financeiras e para fins de persecução de seus próprios interresses definidos em termos regionais ou locais.

Do mesmo modo, a configuração fático-normativa do federalismo fiscal de coordenação implica em assumir o princípio da suficiência financeira como vetor da arquitetura constitucional, segundo o qual os recursos assinalados a cada órgão da estrutura estatal devem ter suficiente respaldo financeiro para fazer frente aos gastos públicos decorrentes de suas atividades públicas. ${ }^{53}$

Em suma, os Estados territoriais historicamente considerados que adotam a forma federativa, como regra, assinalam a competência alocativa de recursos ao ente subnacional, ao passo que as funções de distribuição de rendas e estabilidade macroeconômica são reservadas ao governo central. É esse o caso brasileiro com base na CR/88 e que se levará como referencial para a presente pesquisa, a despeito de serem reconhecidas distorções pontuais na lógica precitada em decorrência de conflitos políticos e financeiros entre os Governadores

\footnotetext{
${ }^{50}$ MIRANDA, Jorge. Teoria do Estado e da Constituição. Rio de Janeiro: Forense, 2002, p. 289.

${ }^{51}$ MUSGRAVE, Richard A. Teoría de la Hacienda Publica. Trad. Jose Maria Lozano Irueste. Madri: Aguilar, 1968 , p. 5.

${ }^{52}$ SCAFF, Fernando Facury. Royalties do Petróleo, Minério e Energia: aspectos constitucionais, financeiros e tributários. São Paulo: RT, 2014, p. 342.

${ }^{53}$ CORTI, Horacio Guillermo. Derecho Constitucional Presupuestario. 2 ed. Buenos Aires: Abeledo-Perrot, 2011, p. 99.
} 
estaduais e as autoridades econômicas federais. ${ }^{54}$

\subsubsection{Soberania Fiscal}

Em que pese o surgimento progressivo de novos atores e centros de poder, os estados permanecem como os principais sujeitos de direito internacional. Nesse ponto, são definidos como entidades que exercem as funções legislativas e executivas em determinada ordem jurídica, além de controlar um terrirório de modo estável e permanente. Eles possuem, portanto, plena capacidade legal, isto é, habilidade de imputar direitos, poderes e obrigações. Ademais, o reconhecimento de novos Estados pressupõe a observância tanto da efetividade do poder no território quanto a legitimidade estatal perante a comunidade internacional. ${ }^{55}$

Ao menos no plano da Teoria do Direito, a história jurídica da soberania se revela na antinomia entre o Direito e a Soberania, uma vez que esta significa a ausência de limites e regras jurídicas, o que leva prima facie ao questionamento acerca da compatibilidade lógica dos termos. Inicialmente, essa antinomia foi resolvida no plano interno por meio do surgimento do Estado Constitucional de Direito no qual o Direito regula a si próprio, de modo que a soberania, se necessária e conveniente, consiste nos limites e vínculos jurídicos na comunidade política. No plano externo, a antinomia se resolveu pelo surgimento de um sistema de normas internacionais ius cogens. No entanto, emergiu um segundo momento com a expansão global do Estado soberano. Na perspectiva externa, a igualdade formal entre os entes estatais é desmentida empiricamente pela desigualdade material entre eles, de modo que prevalece uma soberania limitada, repartida, dependente, diferenciada, endividada. De outro lado, observa-se que a soberania interna declina ao lado do Estado nacional unitário e independente, cuja identidade é posta em xeque com as mudanças emanadas das relações internacionais. ${ }^{56}$

Ainda sobre a configuração da dinâmica interna, verifica-se o que Danilo Zolo chama de "erosão da soberania do Estado nacional" em um processo global no qual os Estados não

\footnotetext{
${ }^{54}$ Cf. LOPREATO, Francisco Luiz Cazeiro. O Colapso das Finanças Estaduais e a Crise da Federação. São Paulo: UNESP, 2002.

${ }^{55}$ CASSESSE, Antonio. International Law. 2 ed. Hampshire: Oxford University Press, 2005, pp. $72-77$.

${ }^{56}$ FERRAJOLI, Luigi. A Soberania no Mundo Moderno. Trad. Carlo Coccioli e Márcio Lauria Filho. São Paulo: Martins Fontes, 2006, pp. 39-45.
} 
possuem mais condições de enfrentar problemas mundiais. ${ }^{57}$ Enfim, considera-se que a situação atual decorreu de problemas globais que tornam o equilíbrio internacional e manutenção da paz interna, promessas e justificativas da soberania, intrinsecamente precários; por outro lado, houve o processo de transnacionalização dos mercados desafiando a capacidade regulatória do ente estatal. Noutras palavras, a crise do Estado nacional como sujeito soberano é marcada no plano externo pela transferência de funções, direitos e obrigações para sedes supraestatais, ao passo que existem impulsos centrífugos e processos de desagregação social os quais evidenciam falhas no projeto de unificação nacional e pacificação do ponto de vista interno. ${ }^{58}$

Segundo Luigi Ferrajoli, esse cenário leva à conclusão da inadequação e obsolência progressiva do paradigma do velho Estado soberano, porquanto "O Estado já é demasiado grande para as coisas pequenas e demasiado pequeno para as coisas grandes" ${ }^{\circledR 5}$. Explica-se: é grande demais para a parcela majoritária das incumbências administrativas para as quais se recorrem aos processos de descentralização, ao passo que é pequeno para as funções de governo e tutela de direitos diante dos processos de internacionalização da economia.

Por evidente, o fenômeno social apresenta reflexos financeiros relevantes, pois no cânone ocidental a formação do Estado territorial teve como condição de possibilidade um processo sociogenético cuja resultante foi o monopólio da tributação. Ou seja, com o aumento da divisão de funções e no curso de incontáveis guerras, a propriedade e prerrogativas da suserania cedem espaço a um controle centralizado dos tributos regulares sobre o território nacional na figura real absolutista. ${ }^{60}$

Visto isso, o problema do financiamento das novas estruturas policêntricas de tomada de decisão remanesce atual e não solucionado, porquanto as categorias jurídicas dos Estados Patrimonial, Fiscal e Endividado não possuem equivalentes funcionais com aptidão instrumental para as operações comunicativas hodiernas. ${ }^{61}$ Nesse ponto, torna-se útil o

\footnotetext{
${ }^{57}$ ZOLO, Danilo. Teoria e Crítica do Estado de Direito. In: COSTA, Pietro; ZOLO, Danilo (orgs.). O Estado de Direito: história, teoria, crítica. Trad. Carlo Alberto Dastoli. São Paulo: Martins Fontes, 2006, pp. 79-80.

${ }^{58}$ FERRAJOLI, Luigi. A Soberania no Mundo Moderno. Trad. Carlo Coccioli e Márcio Lauria Filho. São Paulo: Martins Fontes, 2006, pp. 46-49.

${ }^{59}$ FERRAJOLI, Luigi. A Soberania no Mundo Moderno. Trad. Carlo Coccioli e Márcio Lauria Filho. São Paulo: Martins Fontes, 2006, pp. 50-51.

${ }^{60}$ ELIAS, Norbert. O Processo Civilizador. v. 2. Trad. Ruy Jungmann. São Paulo: Jorge Zahar, 1993, p. 172.

61 "A soberania absoluta, na verdade, nunca existiu. Um Estado sempre teve que limitar-se a situações políticas, geográficas, econômicas que sua realidade impunha. Mas, pelo menos, a sua não-vinculação direta a tratados internacionais, bem como a inexistência de organismos internacionais davam ao Estado este papel formal de ser a fonte mais alta geradora do direito." (BASTOS, Celso Ribeiro. Curso de Direito Financeiro e Tributário. 9 ed. São Paulo: Celso Bastos, 1999, p. 124.)
} 
conceito gramsciano de "crise de autoridade", segundo o qual a crise consiste precisamente no fato de que o velho está por morrer e o novo não pode nascer, logo diversos sintomas patológicos são suscetíveis de aparecimento no período de interregno. ${ }^{62}$ Justamente em um interregno reputa-se passar o Estado brasileiro, notadamente em sua dimensão financeira. Nessa linha, embora de maneira tímida e errática, parcela da doutrina constitucional e financeira já esboça preocupações teóricas e práticas em relação aos impactos da globalização econômica na atividade financeira do Estado. ${ }^{63}$

\subsubsection{Constituição Financeira}

A Constituição como invenção moderna permitiu a ligação entre o jurídico e o político, de modo ser aquela o "estatuto jurídico do político", solucionando o paradoxo da soberania pela auto-vinculação e a referência da produção da ordem jurídica a si própria, ao tornar o texto constitucional fonte de criação e validade de toda norma jurídica.

Aliás, no campo das finanças públicas, há uma relação teleológica e prospectiva entre o Direito Financeiro e a política econômica, uma vez que àquele cabe refletir, por meio de categorias jurídicas, a aspiração política de fazer economicamente possível o cumprimento dos fins ideais de vida da comunidade a cargo do Estado. ${ }^{64}$

$\mathrm{Na}$ contemporaneidade, o direito financeiro desacopla-se do direito econômico, ao ganhar centralidade na organização do capitalismo. Logo, esse ramo jurídico controverte-se e incorpora as tensões e contradições da relação entre o poder do Estado e a sociedade na organização do sistema capitalista. Para Gilberto Bercovici e Luís Fernando Massoneto, o relacionamento entre as dimensões econômicas e financeiras das constituições pauta-se na “organização jurídica do espaço político-econômico da acumulação, modulada de acordo com o regime econômico e com o papel atribuído ao Estado na estruturação do domínio

\footnotetext{
${ }^{62}$ GRAMSCI, Antonio. Essential Classics in Politics: Antonio Gramsci. Londres: ElecBook, 1999, p. 556.

${ }^{63}$ NUNES, António José Avelãs. Quo Vadis, Europa? São Paulo: Contracorrente, 2016; MORAIS, Carlos Blanco de. Curso de Direito Constitucional: teoria da constituição em tempo de crise do estado social. v. 2. t. 2. Coimbra: Coimbra, 2014; HESPANHA, António Manuel. A revolução neoliberal e a Subversão do "modelo Jurídico": crise, direito e argumentação jurídica. In: GOUVEIS, Jorge Bacelar; PIÇARRA, Nuno (orgs.). A Crise e o Direito. Lisboa: Almedina, 2013.

${ }^{64}$ BUJANDA, Fernando Sainz de. Hacienda y Derecho: introducción al Derecho Financiero de nuestro tempo. v. 1. Madri: Instituto de Estudios Politicos, 1963, p. 131.
} 
econômico." 65

Nesse sentido, a valorização jurídica dos direitos fundamentais no bojo do constitucionalismo resulta em direitos constitucionais e respectivos exercícios não condicionados à lógica macroeconômica. Ademais, o constitucionalismo qualifica a oposição como despotismo, isto é, a argumentação prática não sustentável em razões jurídicoconstitucionais veicula alguma modalidade de despotismo, inclusive o econômico. ${ }^{66}$

No campo de uma política constitucional, concebe-se o Direito como arena de tensão entre o mínimo e o pleno dos direitos fundamentais, ou seja, a conflituosidade hermenêutica do Direito decorre, em sua essência, do que são direitos subjetivos em litígios concretos. Nas palavras de Horacio Guillermo Corti, "Fazer política é transformar a ordem jurídica em ordem constitucional, o direito, em Estado de Direito. É mais, torna-se forçoso dizer: esta constituição empírica satisfaz os requisitos que exigimos para que haja, a rigor, uma Constituição."67

Visto isso, na presente subseção, pretende-se gravitar sobre dois eixos de raciocínio: a possibilidade teórica de uma "Constituição Financeira", e a constitucionalização da atividade financeira do Estado.

Em relação a uma Teoria da Constituição Financeira, verifica-se a articulação acadêmica de distinções entre as "subconstituições" no quadro de uma Constituição total com o publicista alemão Klaus Stern. ${ }^{68}$ No direito brasileiro, coube a Ricardo Lobo Torres argumentar por uma relação equilibrada entre as Constituições Financeira, Econômica e Política no âmbito da CR/88. Por sua vez, a Constituição Financeira se subdividira nas modalidades orçamentária, tributária e financeira propriamente dita. ${ }^{69}$

Posteriormente, na seara de sua tese de titularidade, Heleno Taveira Torres desenvolveu a "Teoria da Constituição Financeira”, na qual apresentou a seguinte definição conceitual:

\footnotetext{
${ }^{65}$ BERCOVICI, Gilberto. MASSONETTO, Luís Fernando. A Constituição Dirigente Invertida: a blindagem da constituição financeira e a agonia da constituição económica. In: Boletim de Ciências Económicas, Coimbra, v. 49, 2006, pp. 57-77, p. 59.

${ }^{66}$ CORTI, Horacio Guillermo. Derecho Financiero. Buenos Aires: Abeledo-Perrot, 1997, p. 511.

${ }^{67}$ Tradução Livre: "Hacer política es transformar el orden jurídico em orden constitucional, el derecho em Estado de Derecho. Es más, se parte del forzamiento de decir: esta constitución empírica satisface los requisitos que exigimos para que haya en rigor Constitución." (CORTI, Horacio Guillermo. Derecho Financiero. Buenos Aires: Abeledo-Perrot, 1997, p. 512)

${ }^{68}$ Cf. STERN, Klaus. Derecho del Estado de la Republica Federal Alemana. Trad. Javier Pérez Rojo e Pedro Cruz Villalón. Madri: Centro de Estudios Constitucionales, 1987.

${ }^{69}$ TORRES, Ricardo Lobo. O Orçamento na Constituição. Rio de Janeiro: Renovar, 1995, p. 1.
} 


\begin{abstract}
A Constituição Financeira consiste na parcela material de normas jurídicas integrantes do texto constitucional, composta pelos princípios fundamentais, as competências e os valores que regem a atividade financeira do Estado, na unidade entre obtenção de receitas, orçamento, realização de despesas, gestão do patrimônio estatal e controles internos e externos, bem como a intervenção do Estado, na relação com as Constituições Econômica ou Social.

A Constituição Financeira visa a garantir a certeza do direito a estabilidade sistêmica ao longo de toda a aplicabilidade das competências do direito financeiro, segundo princípios e valores uniformes, nos limites dos direitos e liberdades fundamentais, com máxima efetividade das Constituições Econômica, Político-Federativa e Social. $^{70}$
\end{abstract}

Nesses termos, pretende o jurista pernambucano a assunção de três pressupostos como índices determinantes para tratar o direito financeiro pela Teoria da Constituição Financeira: a prevalência do princípio do Estado Democrático de Direito; os fins constitucionais como definidores dos objetivos da Constituição Financeira; e a abertura sistêmica da Constituição Financeira para a realidade mediante os encontros de valores na relação interna de interconstitucionalidade no quadro da Constituição total. ${ }^{71}$

Com referência à hodierna experiência de redemocratização do Brasil, a Constituição Financeira constitui o Estado Fiscal em seus aspectos formais e materiais. Na dimensão formal, a Constituição financeira coincide com os arts. 145 a 169 da CR/88 (Título VI - Da Tributação e do Orçamento). Noutra banda, é a perspectiva material que transforma o sistema financeiro em um problema político, espraiando-se para outros dispositivos constitucionais, topograficamente deslocados do Título VI da CR/88, como, por exemplo, as competências administrativas e políticas dos entes federativos e dos Poderes da União, a Seguridade Social e o ADCT.

De outro lado, observa-se que o regime constitucional do direito financeiro implica em “identificar as normas que lhe são prórias, não criando um regime jurídico autônomo, mas apartando matéria específica e fazendo incidir sobre ela um plexo de princípios e regras que lhe dão certa identidade." 72 Assim, sob as luzes do tratamento normativo das finanças públicas em nível e momento constitucionais, convém tecer breves comentários a respeito da constitucionalização da atividade financeira do Estado.

\footnotetext{
${ }^{70}$ TORRES, Heleno Taveira. Direito Constitucional Financeiro: teoria da constituição financeira. São Paulo: Revista dos Tribunais, 2014, p. 75.

${ }^{71}$ TORRES, Heleno Taveira. Direito Constitucional Financeiro: teoria da constituição financeira. São Paulo: Revista dos Tribunais, 2014, pp. 76-77.

${ }^{72}$ OLIVEIRA, Regis Fernandes de. Curso de Direito Financeiro. 3 ed. São Paulo: RT, 2010, p. 109.
} 
É corolário da supremacia constitucional a releitura de todo o direito objetivo anterior, quando do advento de uma nova ordem constitucional. Nesse sentido, a migração do fundamento de validade formal e material leva a uma "recriação" das normas infraconstitucionais, a despeito do texto dos diplomas legais restarem inalterados, de modo que cabe à hermenêutica constitucional e a sua comunidade de intérpretes fornecer soluções pragmáticas à constante tensão entre ruptura e continuidade do instituído.

Na particularidade da experiência constitucional brasileira, a chamada doutrina da efetividade dos direitos fundamentais ${ }^{73}$ mostrou-se importante contributo para a superação da dicotomia positivismo normativista/direito alternativo instaurado nos anos de ditadura militar. Isso porque diante da refundação democrática do projeto constitucional do Povo brasileiro não seria mais possível a negativa de um direito posto injusto e autoritário em prol de uma concepção emancipatória e alternativa do Direito que assumisse o conteúdo ideológico do direito para conciliá-lo com o compromisso de reconstrução social. ${ }^{74}$

Por conseguinte, a luta pela conquista de direitos muda seu foco: agora é necessário pensar em meios de aumentar a fruição empírica dos direitos fundamentais pela comunidade política. Para além do reconhecimento de direitos, prodigamente realizado pelo Poder Constituinte no curso do momento constitucional de 1987/1988, deve-se pensar em meios de concretização das promessas civilizatórias do pacto constitucional.

No Estado Constitucional, a preponderância do texto constitucional perante o restante do ordenamento jurídico, o que se pode chamar de supremacia da Constituição (paramount law), reconfigura a vinculação do Poder Público à juridicidade autodeterminada pela soberania popular. Com efeito, compreende-se que as normas constitucionais possuem aplicabilidade imediata e força cogente. Esse quadro, por si só, altera a natureza do Estado de Direito, ao colocá-lo como "Estado de Direitos", em que os direitos fundamentais ocupam posição central no sistema jurídico. ${ }^{75}$

Nesses termos, nota-se a fundamentalidade das normas de direitos fundamentais no ordenamento jurídico nas perspectivas formal e substancial. Pelo lado formal, tem-se que "A fundamentalidade formal das normas de direitos fundamentais decorre da sua posição no ápice da estrutura escalonada do ordenamento jurídico, como direitos que vinculam

\footnotetext{
73 Cf. BARROSO, Luís Roberto. O Direito Constitucional e a Efetividade de suas Normas: limites e possibilidades da Constituição brasileira. 9 ed. Rio de Janeiro: Renovar, 2009.

${ }^{74}$ COELHO, Luiz Fernando. Teoria Crítica do Direito. Curitiba: HDV, 1986, passim.

${ }^{75}$ BONAVIDES, Paulo. Curso de Direito Constitucional. 20 ed. São Paulo: Malheiros, 2007, pp. 584-592.
} 
diretamente o legislador, o Poder Executivo e o Judiciário," ${ }^{, 76}$ sob a ótica substancial, a fundamentalidade se explica a partir da atuação dos direitos fundamentais como instrumentos para a tomada de decisões sobre a estrutura normativa básica do Estado e da sociedade. ${ }^{77}$

Portanto, esse conjunto de transformações no modelo de organização política estatal se identifica com um processo de "constitucionalização do Direito", cuja resultante seria uma ordem jurídica completamente "impregnada" pelas normas constitucionais. Demais, nota-se uma Constituição extremamente invasora, intrometida e condicionante da legislação, jurisprudência, doutrina, ação dos atores políticos e relações sociais. Vale ressaltar, ainda, que a constitucionalização é processo gradativo no tempo e no espaço, porquanto não existe uma resposta binária para o estado da constitucionalização de uma ordem jurídica. ${ }^{78}$

Em síntese, “A idéia de constitucionalização do Direito [...] está associada a um efeito expansivo das normas constitucionais, cujo conteúdo material e axiológico se irradia, com força normativa, por todo o sistema jurídico."79

Nesse sentido, o processo de constitucionalização do Direito envolve dois movimentos fenomênicos distintos. Por um lado, questões antes delegadas ao Poder legiferante passam a ser tratadas pelo Poder Constituinte, o que retira uma série de decisões do alcance das maiorias legislativas momentâneas. De outro, há uma "filtragem constitucional"»0 oportunizada pela conformação do ordenamento jurídico à normatividade constitucional, o que gera uma releitura do Direito posto. ${ }^{81}$ Busca-se, afinal, à realização empírica dos comandos normativos da CR/88.

$\mathrm{Na}$ seara da Constituição Financeira, a constitucionalização como processo faz-se perceber justamente a partir da temática dos custos dos direitos fundamentais, haja vista que o Direito Financeiro atua na qualidade de plataforma de realização de todo projeto constitucional, além de deter substancialidade própria, tendo em conta seu modelo dúplice de

\footnotetext{
${ }^{76}$ ALEXY, Robert. Teoria dos Direitos Fundamentais. Trad. Virgílio Afonso da Silva. São Paulo: Malheiros, 2008, p. 520, grifos no original.

77 ALEXY, Robert. Teoria dos Direitos Fundamentais. Trad. Virgílio Afonso da Silva. São Paulo: Malheiros, 2008 , p. 522.

${ }^{78}$ GUASTINI, Riccardo. La constitucionalización del ordenamiento jurídico: El caso italiano. Trad. José Maria Lujambio. In: CARBONELL, Miguel (Org.). Neoconstitucionalismo(s). 3. ed. Madrid: Editorial Trotta, 2009, pp. 75-98.

${ }_{79}$ BARROSO, Luís Roberto. Neoconstitucionalismo e a constitucionalização do direito (O triunfo tardio do direito constitucional no Brasil). In: SOUZA NETO, Cláudio Pereira de; SARMENTO, Daniel. $A$ Constitucionalização do Direito: Fundamentos Teóricos e Aplicações Específicas. Rio de Janeiro: Lumen Juris, 2007, p. 217.

${ }^{80}$ Cf. SCHIER, Paulo Ricardo. Filtragem Constitucional: construindo uma nova dogmática jurídica. Porto Alegre, Sérgio Antônio Fabris, 1999.

81 SARMENTO, Daniel. Ubiqüidade Constitucional: Os Dois Lados da Moeda. In: SARMENTO, Daniel; SOUZA NETO, Cláudio Pereira de (Coords.). A Constitucionalização do Direito: Fundamentos Teóricos e Aplicações Específicas. Rio de Janeiro: Lumen Juris, 2007, pp. 116-122.
} 
tratamento jurídico como direito positivo e interpretação da ordem constitucional vigente.

Torna-se, ainda, inevitável a assunção dos direitos como assunto de finanças públicas, porquanto são instrumentos politicamente criados e coletivamente financiados para promover o bem-estar humano. Assim, com a clareza de que a exigibilidade de direitos básicos pressupõe a realização de despesas públicas a partir de recursos limitados, coloca-se a questão do financiamento dos direitos no centro dos debates políticos de uma democracia deliberativa. Afinal, é o apoio público que permite a uma ampla coletividade de indivíduos em distintas situações sócio-econômicas usufruir de direitos. ${ }^{82}$

Por conseguinte, ao interpretar os direitos como investimentos direcionados ao aumento do bem-estar geral, financiados pela sociedade para seus próprios fins, surgem questões de transparência e responsabilidade democrática no processo de fixação de recursos, assim como de justiça e ética distributivas. Em síntese, exsurge uma vez mais a tensão entre constitucionalismo e democracia. ${ }^{83}$

Ante as necessidades de garantir processos decisórios democraticamente informados no âmbito do espaço público e o condicionamento do exercício do poder político pelo estatuto jurídico, Eduardo Mendonça argumenta pela centralidade do devido processo orçamentário no processo de constitucionalização do orçamento púbico, uma vez que seu cumprimento atende a duas finalidades: a contenção do poder político em balizas jurídicas; e a promoção da transparência e racionalidade nas decisões estatais. ${ }^{84}$

Assim sendo, verifica-se que o constitucionalismo e a democracia se pressupõem no âmbito das escolhas financeiras, em termos de alocação e distribuição de recursos, levadas a efeito no ciclo orçamentário. Então, a aparente dicotomia entre o democrático e o constitucional é ressignificada na forma de tensão e complemento, com grande potencial produtivo na imaginação e desenvolvimento de uma sociedade criativa e respectiva riqueza social.

\subsection{Democracia Deliberativa e sua Dimensão Financeira}

\footnotetext{
${ }^{82}$ HOLMES, Stephen; SUNSTEIN, Cass. El costo de los derechos: por qué la libertad depende de los impuestos. Trad. Stella Mastrangelo. Buenos Aires: Siglo Veintiuno, 2012, pp. 246-249.

83 "Las decisiones sobre qué derechos - de qué forma - cabe proteger y sobre cuánta riqueza social debe investirse em hacerlo deberían estar sujetas a la crítica y e debate público constantes en proceos de deliberación democrática." (HOLMES, Stephen; SUNSTEIN, Cass. El costo de los derechos: por qué la libertad depende de los impuestos. Trad. Stella Mastrangelo. Buenos Aires: Siglo Veintiuno, 2012, p. 248)

${ }^{84}$ MENDONÇA, Eduardo Bastos Furtado de. A Constitucionalização das Finanças Públicas no Brasil: devido processo orçamentário e democracia. Rio de Janeiro: Renovar, 2010, pp. 131-132.
} 
O ideal de democracia deliberativa possui os seguintes elementos: a inclusão, a deliberação e a igualdade. O primeiro se expressa na presença discursiva de todos os possíveis afetados no processo de deliberação e na tomada de decisão. O elemento deliberativo se entende como a expressão argumentativa do que servirá como fundamento da decisão e teste de correção material do ajustado. Por fim, a dimensão igualitária se dá na situação de igualdade deliberativa de todos os partícipes e co-autores da decisão. ${ }^{85}$

Nas palavras de Heleno Taveira Torres, o ideal democrático condiciona a atividade financeira do Estado, porquanto a observância ao procedimento democrático se revela fonte de legitimidade permanente dos atos públicos. Assim, há uma complementaridade entre o Estado fiscal e a espacialidade participativa da esfera pública, "ao facilitar e compor interesses, no todo ou parte conflituantes quanto à forma de aplicação dos recursos, escolhas dos gastos públicos ou controle da atividade financeira." 86

Por sua vez, Luís Roberto Barroso e Eduardo Mendonça argumentam por uma concepção do orçamento público como ambiente de realização da democracia deliberativa no âmbito das finanças públicas, uma vez que o Parlamento é o fórum público por excelência para a veiculação do devido processo orçamentário, no qual se compõem os interesses conflitantes decorrentes do pluralismo político traduzível no binômio governo-oposição. ${ }^{87}$

Então, na dialogalidade da esfera pública, as decisões orçamentárias são processos compartilhados entre governantes e governados acerca de interesses por meio de consensos democráticos. Revela-se, portanto, "o imperativo de oitiva da sociedade para a formulação de escolhas das ações, metas e processos governativos, bem como do estabelecimento dos recursos necessários." 88

Em suma, percebe-se uma íntima relação entre a democracia e a atividade financeira do Estado para fins de promoção dos direitos fundamentais, à luz da soberania popular, uma vez que é a comunidade política quem deve ser co-autora da decisão financeira por meio da

\footnotetext{
${ }^{85}$ GARGARELlA, Roberto. Teoría y Crítica del Derecho Constitucional. Tomo I. Buenos Aires: Abeledo Perrot, 2008, p. 167.

${ }^{86}$ TORRES, Heleno Taveira. Direito Constitucional Financeiro: teoria da constituição financeira. São Paulo: RT, 2014, p. 138.

${ }^{87}$ BARROSO, Luís Roberto; MENDONÇA, Eduardo. O Sistema Constitucional Orçamentário. In: MARTINS, Ives Gandra da Silva; MENDES, Gilmar Ferreira; NASCIMENTO, Carlos Valder do. Tratado de Direito Financeiro. v. 1. São Paulo: Saraiva, 2013, pp. 262-267.

${ }_{88}$ JUCÁ, Francisco Pedro; ISHIKAWA, Lauro. Orçamento Participativo e Democracia Representativa. In: GOMES, Marcus Lívio; ABRAHAM, Marcus; TORRES, Heleno Taveira (coords.). Direito Financeiro na Jurisprudência do Supremo Tribunal Federal: homenagem ao Ministro Marco Aurélio. Curitiba: Juruá, 2016, p. 192.
} 
cidadania fiscal, assim como é aquela o referencial para a prestação de promessas civilizatórias pelo ente estatal. ${ }^{89}$

\subsection{A Dimensão Constitucional do Orçamento Público}

Em termos históricos, tem-se o orçamento como invenção social pela qual são mediadas lutas políticas das representações populares em torno do fenômeno financeiro, notadamente pelo direito de fiscalizar e controlar o exercício do poder financeiro, por sua vez traduzível na arrecadação de receitas públicas e na administração dos gastos públicos. ${ }^{90}$

Assim, o orçamento público, na qualidade de produto do constitucionalismo liberal, pode ser definido como uma previsão de receitas e de gastos, preocupando-se com a racionalidade econômica da administração pública e a defesa dos direitos e garantias individuais. Para António de Sousa Franco, orçamento público é “uma previsão, em regra anual, das despesas a realizar pelo Estado e dos processos de as cobrir, incorporando a autorização concedida à administração para realizar despesas e cobrar receitas e limitando os poderes financeiros da administração a cada ano."91

Nesse sentido estrito, a lei orçamentária veicularia apenas uma aprovação, porquanto removeria um limite jurídico ao exercício legítimo de um poder-dever ou de um direito reconhecido aos órgãos da administração pelas leis em vigor, em particular voltadas à arrecadação de receitas e obrigação de despesas. ${ }^{92}$

A despeito da subteorização de novas categorias jurídicas vis-à-vis à crise do direito financeiro tradicional ${ }^{93}$ e respectiva ideologia, pode-se afirmar que "a característica essencial

\footnotetext{
${ }^{89}$ CHUEIRI, Vera Karam de; GODOY, Miguel Gualano. Constitucionalismo e democracia: soberania e poder constituinte. Revista Direito GV, São Paulo, v. 6, n. 1, jan./jun. 2010, pp. 159-174, p. 171: “A democracia enquanto conquista e processo de tomada de decisão insere o sujeito/povo nas discussões e deliberações, ao passo que o constitucionalismo regula este processo, estabelecendo limites, padrões e até mesmo determinações."

${ }^{90}$ LEITE, Harrison Ferreira. Autoridade da Lei Orçamentária. Porto Alegre: Livraria do Advogado, 2011, p. 20.

${ }^{91}$ FRANCO, António Luciano de Sousa. Manual de Finanças Públicas e Direito Financeiro. v. 1. Lisboa: Faculdade de Direito de Lisboa, 1974, p. 626, grifos no original.

92 CANOTILHO, José Joaquim Gomes. A Lei do Orçamento na Teoria da Lei. In: Boletim da Faculdade de Direito da Universidade de Coimbra, Estudos em homenagem ao Prof. Doutor J. J. Teixeira Ribeiro II, Coimbra-PT, número especial, 1979, pp. 543-583, pp. 560-564.

93 “Também deve-se, antes, recordar que o direito positivo que disciplina o Orçamento Público sofre, atualmente, de tão profunda crise que as regras jurídicas e princípios financeiros tradicionais do Orçamento Público estão em ruínas e quebram-se todos os anos, em todos os Estados." (BECKER, Alfredo Augusto. Teoria Geral do Direito Tributário. 3 ed. São Paulo: Lejus, 1998, p. 226, grifos originais)
} 
dos orçamentos públicos, hoje em dia, é a que o define como um programa, como um instrumento de planejamento, de direção e de controle da administração pública."94 Por conseguinte, caracteriza-se o plano orçamentário como ato de direção política do Estado.

No plano constitucional, extrai-se um conceito de orçamento público como plêiade de normas jurídicas, por sua vez veiculadas por leis periódicas, que possui o objetivo de estimar receitas e fixar despesas, mas também "concretizar direitos fundamentais, bem como instituir e perseguir metas, diretrizes e objetivos, programas ou políticas públicas com função de planejamento." 95

Com espeque no art. $165, \S 8^{\circ 96}$, da $\mathrm{CR} / 88$, o qual trata fundamentalmente da lei orçamentária anual, haurem-se três propriedades gerais das leis orçamentárias: "a) lei que visa provocar uma conduta especial nos agentes políticos, gerando sanção pelo seu não cumprimento; b) lei que fixa a despesa e prevê a receita; e c) lei concreta de implantação das políticas públicas."97

Posto isso, pretende-se nesta subseção realizar o itinerário argumentativo em dois eixos principais: as construções teoréticas acerca do orçamento público compartilhadas na experiência comparada dos países pertencentes à tradição romano-germânica; e o processo de elaboração e atual estado da arte das normas orçamentárias de índole constitucional.

Em relação ao primeiro eixo, almeja-se partir do conceito constitucional de orçamento público para abordar as funções, os aspectos/elementos e a natureza jurídica dessa instituição no Estado de Direito.

No que se refere ao segundo eixo, a partir da reconstrução do desenvolvimento temático do orçamento e finanças públicas na ANC de 1987/1988, será intentado um esforço exploratório sobre as inovações e estrutura sistemática da positivação das disposições atinentes ao orçamento na $\mathrm{CR} / 88$.

\subsubsection{A lei do orçamento público}

\footnotetext{
${ }^{94}$ SILVA, José Afonso da. Orçamento-Programa no Brasil. São Paulo: Revista dos Tribunais, 1973, pp. 38-39. 95 TORRES, Heleno Taveira. Direito Constitucional Financeiro: teoria da constituição financeira. São Paulo: RT, 2014, p. 349.

${ }^{96} \$ 8^{\circ}$ A lei orçamentária anual não conterá dispositivo estranho à previsão da receita e à fixação da despesa, não se incluindo na proibição a autorização para abertura de créditos suplementares e contratação de operações de crédito, ainda que por antecipação de receita, nos termos da lei.

${ }^{97}$ LEITE, Harrison Ferreira. Autoridade da Lei Orçamentária. Porto Alegre: Livraria do Advogado, 2011, p. 19.
} 
$\mathrm{Na}$ opinião de Alfredo Augusto Becker, “A regra jurídica que aprova o Orçamento Público é a regra de Direito Positivo na qual se concentra o mais intenso grau de positividade; ela é, a priori, a mais constitucional das regras jurídicas," ${ }^{98}$ tendo em vista sua fundamentalidade para a existência do Estado, uma vez que o ente estatal frui de sua existência no espaço fiscal do orçamento público. Daí que retira a lei orçamentária sua autoridade constitucional em sentido material.

Do ponto de vista formal, o devido processo legislativo orçamentário qualifica o orçamento público como lei, com a mesma ou maior ${ }^{99}$ posição hierárquica em comparação às demais leis protetivas de direitos e impositivas de deveres, passível de alteração somente pelos mecanismos legais existentes.

Nesse arcabouço normativo, há funções democráticas previstas na Constituição Financeira e atribuídas ao orçamento público, ao menos cinco a seguir listadas ${ }^{100}$ : (i) limitação parlamentar, porquanto representa vinculação da Administração Pública às decisões políticas de alocação dos recursos por parte do Poder Legislativo, por meio da legalidade orçamentária, a despeito de sensível divergência doutrinária acerca das dimensões autorizativa ou impositiva das leis orçamentárias; (ii) planejamento, por caber às leis orçamentárias viabilizar financeiramente os planos nacionais ${ }^{101}$; (iii) transparência, pois um processo, fato ou informação referentes ao orçamento público devem ser abertos e disponíveis para exame e escrutínio sociais, nos planos da disponibilidade e da usabilidade ${ }^{102}$; (iv) efetivação dos direitos e liberades fundamentais, ao dispor de verbas públicas e suportar os gastos decorrentes do processo de proteção e promoção desses interesses juridicamente qualificados; e (v) controle ${ }^{103}$, ao viabilizar o controle político pelo Poder Legislativo sobre a proposta

\footnotetext{
${ }^{98}$ BECKER, Alfredo Augusto. Teoria Geral do Direito Tributário. 3 ed. São Paulo: Lejus, 1998, p. 230.

99 Acerca das normas gerais do orçamento público como leis reforçadas ou leis de plano, confira-se: CANOTILHO, José Joaquim Gomes. A Lei do Orçamento na Teoria da Lei. In: Boletim da Faculdade de Direito da Universidade de Coimbra, Estudos em homenagem ao Prof. Doutor J. J. Teixeira Ribeiro II, Coimbra-PT, número especial, 1979, pp. 543-583, pp. 558-560.

${ }^{100}$ TORRES, Heleno Taveira. Direito Constitucional Financeiro: teoria da constituição financeira. São Paulo: RT, 2014, p. 349.

101 "O Planejamento é imprescindível para a alocação eficiente de recursos e previsibilidade dos eventos futuros. Entende-se por planejamento um processo de eleição de ações, prioridades, metas, com o intuito de evitar desperdícios de recursos, determinar o caminho a ser trilhado e dos instrumentos a serem utilizados, além de coordenar as ações do agente público e buscar a previsibilidade dos seus efeitos. A atividade - o processo de planejar - requer, hoje, que seja amplo e aberto para a discussão coletiva." (KANAYAMA, Rodrigo Luís. Direito, Política e Consenso: a escolha eficiente de políticas públicas. 226 f. Tese de Doutorado - Faculdade de Direito, Universidade Federal do Paraná, Curitiba, 2012, pp. 24-25)

${ }^{102}$ SCHAUER, Frederick. Transparency in Three Dimensions. University of Illinois Law Review, Ilinois-EUA, n. 4, 2011, pp. 1339-1358, pp.1343-1344, pp. 5-8.

103 "A necessidade de que toda e qualquer atividade desenvolvida pelo Estado esteja sujeita a diferentes níveis ou mecanismos de controle se faz presente desde que se concebeu o Estado de Direito" (FURTADO, Lucas Rocha.
} 
orçamentária dos Poderes e órgãos dotados de autonomia financeira, à luz de uma gestão republicana e responsável do gasto público.

Além disso, como fenômeno social estruturante do Estado, a doutrina financeirista costuma apontar aspectos ou elementos do orçamento público atinentes a diversos campos do conhecimento social, sobretudo o político, econômico, jurídico e técnico-contábil.

No plano político, o orçamento é a autorização popular, direta ou representada, para a condução de um projeto de governo, por intermédio de uma gestão orçamentária das atividades do Estado. ${ }^{104}$

Na seara econômica, o orçamento congloba todas as receitas e despesas públicas, de modo a expor analiticamente a atividade financeira do Estado em determinado ciclo orçamentário, atuando sobre e na economia. "O orçamento poderá, de acordo com a política orçamentária de cada governo e em certo momento, ser superavitário ou deficitário, sendo certo que hoje em dia a maior parte das nações democráticas busca ter um orçamento equilibrado." 105

Ademais, o orçamento público deve ser elaborado com o fito de contabilização e uniformização das contas públicas, à luz da disciplina da contalibilidade governamental. Trata-se do aspecto técnico-contábil do orçamento, o qual predominou no ideário do Estado liberal em que a funcionalidade precípua da peça orçamentária era a previsão de despesas e receitas, inclusive despida de juridicidade material, como se verá a seguir.

Por fim, o orçamento público é uma lei. Assim, de sua estatura legal extrai-se a vinculatividade de seus comandos normativos como limitadores da Administração Pública, de modo que a gestão, receitas e despesas públicas devem possuir guarida legal, à luz do princípio da legalidade. Eis o aspecto jurídico do orçamento público o qual irá interessar mais no âmbito desta pesquisa.

A propósito, torna-se imperativo tecer maiores considerações sobre a natureza jurídica do orçamento público, haja vista sua relevância para o posicionamento da lei orçamentária no ordenamento jurídico e o deslinde da controvérsia acerca da realização de controle de constitucionalidade em relação ao orçamento.

A função de Controle como fundamento do Estado Democrático de Direito. In: Revista Escola Nacional da Magistratura, Brasília, a. 7, n. 6, pp. 424-441, nov. 2012, p. 424)

${ }^{104}$ FRANCO, António Luciano de Sousa. Manual de Finanças Públicas e Direito Financeiro. v. 1. Lisboa: Faculdade de Direito de Lisboa, 1974, p. 629.

${ }^{105}$ ABRAHAM, Marcus. Curso de Direito Financeiro Brasileiro. 3 ed. Rio de Janeiro: Forense, 2015, p. 253. 
No plano jurídico, a natureza do orçamento público importa para a definição do regime jurídico aplicável à espécie, representando, dentre outras coisas, o grau de vinculatividade e eficácia de seus enunciados ao Poder Público. Para além do formalismo conceitualista, Canotilho rememora que "a problemática jurídico-constitucional do orçamento era, em grande parte, o fruto das condições sócio-económicas imperantes no momento histórico em que foram formuladas e que ela estava indissociavelmente ligada a uma certa ideologia constitucional". ${ }^{106}$ De fato, a ligação do orçamento público com o duplo conceito de lei, marcado pela distinção conceitual entre lei em sentidos material e formal, representou uma importante construção jurídica para a solução da crise prussiana no processo de unificação territorial e, por efeito, a afirmação jurídico-política do princípio monárquico.

Ao fim e ao cabo, havia um conflito político decorrente do retorno do regime absolutista proposto no Congresso de Viena, após a derrocada do Império napoleônico e a resistência da burguesia em aceitá-lo. Em termos institucionais, buscava-se com o princípio monárquico harmonizar o antigo regime com a nova ordem social, sem cair nos ideais revolucionários liberais. Logo, no sistema da monarquia limitada constitucional, a Coroa era a instituição fundamental do Estado e somente ao Rei correspondia o exercício da soberania como autoridade constituinte, ao passo que o Parlamento possuía papel restrito de limitação ao poder real, embora reclamasse por legitimidade a partir do ideal de representação da participação democrática da burguesia na formação da vontade política do Estado, inclusive em sua dimensão financeira. ${ }^{107}$

A esse respeito, encontra-se em Paul Laband e seu conceito duplo de lei o referencial teórico para uma justificativa jurídica ao problema da natureza da lei orçamentária, sob as luzes do contexto de crise prussiana. Nesse sentido, separou-se a lei em sentido formal (exigência normativa de que a manifestação da vontade estatal ocorra por meio de Lei) e em sentido material (conteúdo normativo que expresse um preceito regulamentador de relações jurídicas, por meio de normas gerais, abstratas e permanentes). Nessa linha, o orçamento público seria lei somente em sentido formal, pois expressaria apenas um ato administrativo, uma conta de receitas e despesas. Por isso, o Parlamento teria competência para alterar ingressos ou gastos orçamentários somente no que fosse discricionário, então se excluía da

\footnotetext{
${ }^{106}$ CANOTILHO, José Joaquim Gomes. A Lei do Orçamento na Teoria da Lei. In: Boletim da Faculdade de Direito da Universidade de Coimbra, Estudos em homenagem ao Prof. Doutor J. J. Teixeira Ribeiro II, Coimbra-PT, número especial, 1979, pp. 543-583, p. 544.

107 TIMBÓ, Ivo Cordeiro Pinho. A Natureza Jurídica do Orçamento Público. 309f. Tese de Doutorado Universidade Presbiteriana Mackenzie, São Paulo, 2013, pp. 91-106.
} 
apreciação paralmentar as receitas, as obrigações assumidas pelo Estado e a manutenção das instituições estatais. ${ }^{108}$ Em síntese, “A doutrina de Laband consiste em despir o orçamento de qualquer significação jurídica, considerando-o tão somente como um expediente de ordem prática, destinado a pôr ordem na Administração." 109

Essa digressão seria apenas uma curiosidade histórica, não fosse pela influência e capilaridade do pensamento de Paul Laband na Europa continental e posteriormente na América Latina, de modo que, ainda hoje e em regimes e sistemas de governo muito distintos daquelas circunstâncias sócio-políticas que ensejaram a distinção do caráter dúplice da lei orçamentária, a questão sobre a natureza jurídica do orçamento público remanesce presente no ideário do Direito Financeiro, com sensíveis impactos nos desenhos institucionais da atividade financeira do Estado.

No caso brasileiro, observou-se verdadeiro transplante constitucional ${ }^{110}$ em relação ao instituto do "duplo conceito de lei", de modo que há mais de um século discute-se a natureza "enigmática" da lei que aprova o orçamento público na dogmática jurídica. Nessa seara, há três possibilidades compreensivas da lei orçamentária: (i) formal; (ii) material; e (iii) sui generis.

Aqueles que defendem a natureza formal do orçamento afirmam que a lei não teria qualquer função na constituição de direitos subjetivos para terceiros, sendo que sua força persistiria apenas como controle negativo do Poder Executivo. Assim, a dicotomia entre lei formal e lei material permaneceria válida na seara financeira, porquanto se exige apenas que o orçamento se manifeste na forma de lei, não havendo vinculatividade ao gestor das despesas na execução, por conta do caráter autorizativo da programação. ${ }^{111}$

Os teóricos que concebem a natureza da lei orçamentária como sui generis articulam que o diploma se qualifica como lei sob o enfoque formal, contudo é ato-condição de efeitos concretos em termos materiais. Em suma, "a lei orçamentária difere das demais leis,

\footnotetext{
${ }^{108}$ LABAND, Paul. Derecho Presupuestario. Trad. José Zamit. Madri: Instituto de Estudios Fiscales, 1979, passim.

${ }^{109}$ CAMPOS, Francisco. Orçamento - natureza jurídica - lei material e lei formal - exposição e crítica da doutrina de Laband - direito comparado - elevação do imposto de vendas e consignações em São Paulo. In: Revista de Direito Administrativo, Rio de Janeiro, v. 14, jan. 1948, pp. 447-467, p. 448.

${ }^{110}$ Metáfora corrente no Direito Comparado com potencial explicativo sobre o fenômeno de transferência de leis, institutuos e instituições jurídicas entre fronteiras geopolíticas ou culturais: "Os transplantes legais, no âmbito do direito comparado, buscam explicar como ocorre a dinâmica de interação recíproca entre os sitemas legais e como as transferências ocorridas influenciam - ou até mesmo modificam - os referidos sistemas entre si" (SILVA, Christine Oliveira Peter da. Transjusfundamentalidade: diálogos transnacionais sobre direitos fundamentais. Curitiba: CRV, 2014, p. 108)

${ }^{111}$ TORRES, Ricardo Lobo. O Orçamento na Constituição. Rio de Janeiro: Renovar, 1995, p. 64.
} 
caracterizadas por serem genéricas, abstratas e constantes ou permanentes. Ela é, na verdade, uma lei de efeito concreto para vigorar por um prazo determinado de um ano, fato que, do ponto de vista material, retira-lhe o caráter de lei.",112

Contudo, demonstra-se que os fundamentos dessas concepções de orçamento público já não encontram mais referencial no ordenamento jurídico brasileiro. Segundo Harrison Leite, há, no mínimo, quatro razões para essa afirmação ${ }^{113}$ : a forma e o sistema de governo (republicano e presidencialista em que o Poder Legislativo possui papel destacado na orçamentação); a normatividade constitucional; a ultrapassada base doutrinária ${ }^{114}$; e os reclamos dos tempos atuais ${ }^{115}$.

Nesse sentido, a substancialidade do orçamento público possui derivação direta da ordem constitucional, porquanto aquele é qualificado como lei, cujos efeitos típicos consistem em vincular o Poder Público a observar as condições dos créditos orçamentários, mesmo que não haja um dever de gastar recursos públicos de modo impositivo. De qualquer modo, a cada ingresso ou saída orçamentários decorrem possibilidades deônticas para a conduta social, como obrigação, permissão ou proibição.

Justamente da deliberação democrática no processo legislativo qualificado, consoante o disposto no art. 166 da CR/88, emana-se materialidade da lei orçamentária. Além disso, a inobservância de suas prescrições normativas acarretam responsabilização nas searas administrativa, cível, criminal e política (crime de responsabilidade, sanções eleitorais e inelegibilidades). ${ }^{116}$

Em sumário às ideias aqui defendidas e em razão de sua relevância, transcreve-se trecho do pensamento doutrinário de Heleno Taveira Torres:

O orçamento público é a lei que estabelece a unidade da atividade financeira estatal e para qual convergem todas as relações da interconstitucionalidade material do Estado Democrático de Direito, para concretização dos seus fins constitucionais. Portanto, o efeito de vinculação do orçamento deflui da Constituição, e não do ato

\footnotetext{
${ }^{112}$ HARADA, Kiyoshi. Direito Financeiro e Tributário. 25 ed. São Paulo: Atlas, 2016, p. 70.

${ }^{113}$ LEITE, Harrison Ferreira. Autoridade da Lei Orçamentária. Porto Alegre: Livraria do Advogado, 2011, pp. 49-57.

${ }^{114}$ Acerca das inconsistências científicas e jurídicas da teoria da lei orçamentária de Laband, veja-se: TIMBÓ, Ivo Cordeiro Pinho. A Natureza Jurídica do Orçamento Público. 309f. Tese de Doutorado - Universidade Presbiteriana Mackenzie, São Paulo, 2013, pp. 174 e ss.

115 Sobre a intransponibilidade do caráter dual da lei para o moderno Estado Social de Direito, confira-se: MONCADA, Luis S. Cabral de. A ploblemática juridica do planeamento económico. Coimbra: Coimbra, 1985, p. 187.

${ }^{116}$ HARADA, Kiyoshi. Direito Financeiro e Tributário. 25 ed. São Paulo: Atlas, 2016, p. 71.
} 
administrativo que organiza a unidade do documento orçamentário que se vê encaminhado ao Poder Legislativo como "proposta" de orçamento. ${ }^{117}$

No âmbito jurisprudencial, também se nota trajetória semelhante desde a concepção formalista à substancial da lei orçamentária, ao menos para o STF, como será visto de maneira mais verticalizada no Capítulo 2. De qualquer modo, já na década de 1950, há julgamentos da Primeira Turma do STF no sentido da natureza meramente formal da lei orçamentária, com interessante digressão doutrinária do Ministro Ribeiro da Costa no RE $17.184^{118}$. No mesmo sentido, noticia-se o RE 34.581, de relatoria do Ministro Cândido Motta, ${ }^{119}$ para quem a lei que aprova o orçamento público não gera direito subjetivo a ser assegurado por via judicial.

Mesmo com o advento da nova estrutura constitucional na CR/88, o STF remanesceu com o vetusto entendimento no sentido da natureza formal da lei orçamentária, ao não conhecer de ADI cujo objeto era lei orçamentária. Nesse sentido, confiram-se as ADI $2.100^{120}$, de relatoria do Ministro Néri da Silveira e com redação para acórdão do Ministro Nelson Jobim, e ADI-MC $2.535^{121}$, de relatoria do Ministro Sepúlveda Pertence, ambas julgadas no Plenário da Corte.

Porém, a partir da ADI $1.925^{122}$, de relatoria da Ministra Ellen Gracie e com acórdão redigido pelo Ministro Marco Aurélio, o STF passou a admitir o ajuizamento de ADI em face de LDO, desde que o dispositivo impugnado expressasse violação direta à CR/88. Assim, embora sem revisitar o caráter dual e os efeitos concretos da lei do orçamento, o Tribunal, por sua maioria, entendeu que é possível extrair-se de lei orçamentária direitos subjetivos

\footnotetext{
117 TORRES, Heleno Taveira. Direito Constitucional Financeiro: teoria da constituição financeira. São Paulo: RT, 2014, p. 395.

118 BRASIL. SUPREMO TRIBUNAL FEDERAL. Recurso Extraordinário 17.184, Relatoria do Ministro Ribeiro da Costa, j. 03.07.1952. Disponível em: $\langle$ http://bibliotecadigital.fgv.br/ojs/index.php/rda/article/viewFile/14343/13233〉. Acesso em 15.07.2016.

119 BRASIL. SUPREMO TRIBUNAL FEDERAL. Recurso Extraordinário 34.581, Relatoria do Ministro Cândido Motta, j. 10.10.1957, RT 282/859.

120 “CONSTITUCIONAL. LEI DE DIRETRIZES ORÇAMENTÁRIAS. VINCULAÇÃO DE PERCENTUAIS A PROGRAMAS. PREVISÃO DA INCLUSÃO OBRIGATÓRIA DE INVESTIMENTOS NÃO EXECUTADOS DO ORÇAMENTO ANTERIOR NO NOVO. EFEITOS CONCRETOS. NÃO SE CONHECE DE AÇÃO QUANTO A LEI DESTA NATUREZA. SALVO QUANDO ESTABELECER NORMA GERAL E ABSTRATA. AÇÃO NÃO CONHECIDA.” (BRASIL. SUPREMO TRIBUNAL FEDERAL. Ação Direta de Inconstitucionalidade 2.100, Relatoria do Ministro Néri da Silveira, Relator para acórdão Ministro Nelson Jobim, Tribunal Pleno, j. 17.12.1999, Publ em DJ $1^{\circ} .06 .2001$, pp. 238-248)

${ }^{121}$ BRASIL. SUPREMO TRIBUNAL FEDERAL. Medida Cautelar em Ação Direta de Inconstitucionalidade 2.535, Relatoria do Ministro Sepúlveda Pertence, Tribunal Pleno, j. 19.12.2001, Publ. em DJ 21.11.2003, pp. 368-400.

${ }^{122}$ BRASIL. SUPREMO TRIBUNAL FEDERAL. Ação Direta de Inconstitucionalidade 2.925, Plenário, Relatoria Ministra Ellen Gracie, Relatoria para acórdão Ministro Marco Aurélio, j. 19.12.2003, Publ. DJ 04.03.2005, pp. 112-188.
} 
passíveis de sindicabilidade judicial em fiscalização abstrata.

Enfim, a despeito de não haver posicionamento iterativo quanto ao tema, já há parcela dos membros do STF que defendem uma "vinculatividade mínima" do orçamento público, o que não corresponderia a um dever de executar a programação de despesas, tal como aprovada na LOA, mas sim a necessidade de fundamentação por parte do Poder Executivo ao não destinar os valores à finalidade versada na peça orçamentária. ${ }^{123}$

\subsubsection{O orçamento público na Constituição da República de 1988}

O processo constituinte da $\mathrm{CR} / 88$ pode ser considerado um dos mais interessantes experimentos sócio-políticos da história brasileira, assim como na experiência comparada, tendo em vista (i) a intensidade da participação cívica envolvida e (ii) a ausência de um bloco hegemônico de poder com capacidade de impor previamente as condições e o escopo da disputa política em momento constitucional.

Nesse sentido, o início desse processo deu-se com o movimento popular das "Diretas Já”, uma vez que este marcou o reencontro do Povo brasileiro com a política duas dezenas de anos após um golpe militar. Logo, mesmo com a derrota da Emenda Dante de Oliveira, a mobilização política mudou a história brasileira, dado que tornou inevitável a realização da Constituinte, por meio da eleição indireta de Tancredo Neves no Colégio Eleitoral e a convocação da Assembleia Constituinte pelo Presidente José Sarney. ${ }^{124}$ Em suma, torna-se claro que a luta pelas eleições por voto direto e popular significava, ao fim e ao cabo, a luta por uma nova e democrática Constituição. ${ }^{125}$

\footnotetext{
123 “O SENHOR MINISTRO MARCO AURÉLIO - Presidente, percebi que o ministro Luiz Fux adota a teoria da vinculação.

O SENHOR MINISTRO LUIZ FUX (RELATOR) - Mínima.

O SENHOR MINISTRO MARCO AURÉLIO - Mínima, pelo menos, devendo o Executivo justificar por que não destina os valores à finalidade versada no orçamento. Este não seria simplesmente autorizativo. Creio que concordamos nessa óptica (...) é bom que se proclame e que o Supremo venha a adotar posição definitiva a respeito que o orçamento não é algo simplesmente formal, lírico, ficando à discrição do Poder Executivo observar, ou não, as políticas públicas nele previstas em termos de aplicação de recursos.

O SENHOR MINISTRO LUIZ FUX (RELATOR) - Eu estou de acordo com Vossa Excelência." (BRASIL. SUPREMO TRIBUNAL FEDERAL. Referendo em Medida Cautelar em Ação Direta de Inconstitucionalidade 4.663, Relatoria Ministro Luiz Fux, Tribunal Pleno, j. 15.10.2014, DJe 246, Publ. em 16.12.2014, p. 11)

${ }^{124}$ PINTO, Marcos Barbosa. Constituição e Democracia. Rio de Janeiro: Renovar, 2009, pp. 69-75.

125 "A agenda política da oposição institucional se construiu em torno de quatro reivindicações fundamentais: retorno ao Estado de direito, anistia política, eleições diretas para presidente da República e uma nova Constituição. Esses pleitos e essas demandas delinearam o projeto democrático do MDB para o país (Kinzo,
} 
Em relação às particularidades do processo constituinte em tela, a intensidade da participação cívica não teve precedentes na formação histórica brasiliana, porquanto se iniciou sem agenda prévia, os trabalhos foram descentralizados por meio de comissões com amplas discussões com a sociedade civil e permitiram-se emendas populares as quais totalizaram 120 (cento e vinte) com amparo em mais de 12 (doze) milhões de assinaturas. Nesses termos, pode-se afirmar que os dois anos de funcionamento da Constituinte representaram um período singular de debate político caracterizado pela abertura às instâncias sociais; a publicidade mediante o acompanhamento midiático e social; e profundo pela riqueza de argumentos, matizes ideológicas e movimentos sociais civicamente engajados no processo de elaboração do texto da $\mathrm{CR} / 88 .^{126}$

Por outro lado, enxerga-se o processo constituinte como expressão de uma crise de hegemonia localizada historicamente na redemocratização, pois o bloco de apoio político da ditadura militar se desagregou a ponto de não controlar a transição para a democracia, ao passo que não houve a formação de um bloco alternativo com aptidão para dirigir o processo. Por conseguinte, a Constituinte foi um processo descentralizado e poliocêntrico no qual as diversas forças políticas buscaram a posição hegemônica sem êxito. Assim, "O processo constituinte fez com que todas as forças políticas passassem a recorrer ao direito para conquistar e preservar espaços na luta por direitos e por fundos públicos."127 Conclui-se que foram justamente as contradições da CR/88 que permitiram sua legitimidade e vitalidade na medida em que diferentes grupos e movimentos buscam a fundamentação de suas ações e objetivos políticos no texto constitucional.

A partir dessa visão panorâmica, convém focalizar no tratamento dispensado às finanças públicas em geral e ao orçamento público em particular no curso do processo constituinte. No campo do relacionamento entre os Poderes, percebe-se como um dos grandes desafios do Poder Constituinte a apresentação de uma proposta de solução ao "problema do orçamento", especialmente na interação entre o Executivo e o Legislativo. A propósito, o "problema do orçamento" pode ser sintetizado na seguinte inquirição elaborada por Antonio Sérvio Carvalho Rocha: “de que forma seria possível efetuar um desenho constitucional que

1988). Por certo, a prioridade e a sequência de tais conquistas não eram, e não podiam ser, objeto de escolha deliberada - em parte, pela adversas circunstâncias políticas em que se vivia, mas também pelas disputas no interior da própria agremiação oposicionista." (ROCHA, Antônio Sérgio. Genealogia da Constituinte: do autoritarismo à democratização. In: Lua Nova, São Paulo, n. 88, 2013, pp. 29-87, p. 37)

${ }_{126}^{12}$ PINTO, Marcos Barbosa. Constituição e Democracia. Rio de Janeiro: Renovar, 2009, pp. 79-85.

${ }^{127}$ NOBRE, Marcos. Indeterminação e Estabilidade. In: Novos Estudos, São Paulo, n. 82, nov. 2008, pp. 97-106, p. 101. 
recuperasse a racionalidade econômica do Estado com a construção de uma participação parlamentar própria a um regime democrático?"128

Nesse ponto, havia uma repulsão, de plano, ao que se considerava os erros das experiências institucionais anteriores, nos excessos seja de participação, seja de eficientismo, aqui consideradas duas: a "solução populista" no período de 1946-1963 e a "solução autoritária" de 1964-1984. Na primeira, em reação aos abusos do Estado Novo no qual toda política orçamentária era formulada e processada nos ministérios da Presidência da República, institucionalizou-se a lei orçamentária como único instrumento para veicular estimativa de receitas e fixação de despesas, ao mesmo tempo em que havia liberdade ampla e irrestrita do Legislativo para a modificação da proposta do Executivo por meio de emendas parlamentares, de modo a comprometer a integridade dos programas e políticas de governo. Assim, o desenho institucional apresentava propensão ao déficit, uma vez que "A legislação aprovada no Congresso já trazia despesas em montante superior às receitas orçadas. A percepção generalizada era que a indisciplina fiscal do Congresso estava no epicentro das dificuldades econômicas do país." "129

Noutra banda, o Congresso Nacional foi completamente alijado do processo orçamentário no regime militar, por intermédio de restrições tanto à instituição, quanto aos parlamentares, em prol de uma racionalidade macroeconômica levada a efeito pelo governo central. Nesse sentido, implementou-se um sistema de orçamentos múltiplos, sendo que somente o Orçamento Geral da União ou Orçamento Fiscal era submetido à apreciação do Poder Legislativo, sendo aquele consistente em uma complexa combinação de receitas e despesas parcialmente consideradas, conquanto os Orçamentos Monetário, da Previdência Social (SINPAS) e da Administração Indireta não se sujeitavam a regimes de controle ou fiscalização por parte das instâncias parlamentares ou sociais. A esse labirintítico aparato orçamentário somavam-se o duplo comando das Autoridades Monetárias e a autonomia do Banco Central para gestão da dívida pública interna, ocasionando uma desgovernança institucional do setor público do país, cujos reflexos econômicos foram dispersão e opacidade da política fiscal, déficit público, crise econômica e hiperinflação. ${ }^{130}$

Em síntese, nessa dicotomia entre participação parlamentar e eficiência

\footnotetext{
${ }^{128}$ ROCHA, Antonio Sérgio Carvalho. As Partes e o Todo: congresso nacional, executivo e o problema do orçamento no Brasil. In: Perspectivas, São Paulo, v. 34, jul.dez. 2008, pp. 55-78, p. 55.

${ }^{129}$ ROCHA, Antonio Sérgio Carvalho. As Partes e o Todo: congresso nacional, executivo e o problema do orçamento no Brasil. In: Perspectivas, São Paulo, v. 34, jul.dez. 2008, pp. 55-78, p. 60.

${ }^{130}$ ROCHA, Antonio Sérgio Carvalho. As Partes e o Todo: congresso nacional, executivo e o problema do orçamento no Brasil. In: Perspectivas, São Paulo, v. 34, jul.dez. 2008, pp. 55-78, pp. 60-63.
} 
macroeconômica, buscou-se na ANC de 1987/1988 a constitucionalização de uma nova "solução orçamentária" mais produtiva e adequada às exigências democráticas formuladas na esfera pública. Após a instalação dos trabalhos em março de 1987, o processo constituinte pode ser organizado em três grandes etapas: Comissões Temáticas, Comissão de Sistematização e Plenário.

Os dispositivos constitucionais atinentes ao orçamento público foram discutidos em duas comissões temáticas: a Comissão do Sistema Tributário, Orçamento e Finanças, presidida por Francisco Dornelles, cuja relatoria coube a José Serra e foi composta por 62 (sessenta e dois) deputados e senadores constituintes, por sua vez desdobrada em três subcomissões - (i) Tributos, Participação e Distribuição das Receitas, (ii) Orçamento e Fiscalização Financeira e (iii) Sistema Financeiro -; e a Comissão da Organização dos Poderes e Sistema de Governo, presidida por Bocayuva Cunha e relatada por José Jorge, na qual também se apreciou a matéria "orçamentos públicos". Nesse sentido, as subcomissões apresentaram e aprovaram seus relatórios parciais, os quais foram reunidos em outro relatório de trabalho de competência das comissões, datadas de junho de 1987.

Após, os anteprojetos aprovados pelas comissões temáticas foram submetidos ao crivo da Comissão de Sistematização, presidida por Afonso Arinos e sob relatoria de Bernardo Cabral, formada pelos presidentes e relatores das sete comissões temáticas, bem como por constituintes especialmente designados para essa fase. Consolidadas e sistematizadas as matérias aprovadas nas comissões temáticas, o relator apresentou um projeto de Constituição. Emendado e aprovado em julho de 1987, esse projeto passou por três rodadas de trabalho nas quais fora aperfeiçoado na forma de substitutivos.

Por fim, os resultados dos trabalhos da Comissão de Sistematização foram submetidos à apreciação do Plenário, sob a presidência de Ulysses Guimarães e também com relatoria de Bernardo Cabral. O projeto foi debatido em dois turnos de votação com características e possiblidades de alteração distintas, pois o primeiro turno foi marcado pela atuação do bloco parlamentar denominado "Centrão" em que era possível a alteração integral do texto do anteprojeto, enquanto na segunda fase as emendas só puderam ter caráter supressivo. A votação do segundo turno foi finalizada em setembro de 1988. Após isso, submeteu-se o texto à correção de erros e aperfeiçoamentos, sem alteração meritual, de modo que a redação final do projeto de Constituição foi submetida à votação no Plenário Geral ad referendum. Em 05 
de outubro de 1988, a CR/88 foi promulgada pela ANC. ${ }^{131}$

Na temática do orçamento público, os debates e as decisões políticas levados a cabo ao longo do processo constituinte não destoaram do fio condutor da $\mathrm{ANC}$, embora tenham ocorrido algumas peculiaridades em relação às quais cabem comentários.

De modo geral, três foram as diretrizes condutoras dos trabalhos da Comissão do Sistema Tributário, Orçamento e Finanças em relação ao tema do orçamento público: (i) a reunificação orçamentária; (ii) o restabelecimento do planejamento de médio prazo na Administração Pública, notadamente por meio de novos instrumentos no ciclo orçamentário; e, sem dúvidas a mais importante, (iii) a recuperação de prerrogativas do Poder Legislativo para elaboração do orçamento e fiscalização de sua execução. ${ }^{132}$

Nesse sentido, os trabalhos dessa Comissão temática destoaram do restante do processo constituinte, uma vez que os embates políticos e ideológicos próprios de uma crise de hegemonia não se fizeram presentes com a mesma intensidade. Segundo o presidente da Comissão Francisco Dornelles, construiu-se um forte consenso político acerca da temática, de modo que o texto foi pouco modificado ao longo do processo, sem maiores interferências do governo central ou mesmo sem alterações de relevo nos substitutivos globais apresentados pelo grupo de constituintes conhecido como "Centrão" no primeiro turno de votação do Plenário Geral. $^{133}$

Do mesmo modo, a atenção da matéria foi monopolizada por um grupo reduzido de parlamentares a ponto de ser possível nomeá-los: César Maia (PDT-RJ), José Jorge (PFL-PE), José Serra (PMDB-SP) e Fernando Henrique Cardoso (PMDB-SP), assim como, com menos frequência, Osmundo Rebouças (PMDB-CE), Firmo de Castro (PMDB-CE), José Luiz Maia (PDS-PI) e Vílson Souza (PMDB-SC). ${ }^{134}$

Além disso, não houve maiores polêmicas em termos substantivos acerca da redação dos diversos anteprojetos e substitutivos. Na verdade, a maior parte das discussões concentrou-se em torno de três questões: o papel dos instrumentos orçamentários de planejamento na redução das desigualdades regionais; as competências atribuídas à CMO; e a

\footnotetext{
131 AFONSO, José Roberto. Memória da Assembléia Constituinte de 1987/88: as finanças públicas. In: Revista do BNDES, Rio de Janeiro, v. 6, n. 11, 1999, pp. 21-48, pp. 23-25.

132 ROCHA, Antonio Sérgio Carvalho. As Partes e o Todo: congresso nacional, executivo e o problema do orçamento no Brasil. In: Perspectivas, São Paulo, v. 34, jul.dez. 2008, pp. 55-78, p. 64.

${ }^{133}$ Cf. DORNELLES, Francisco. O Sistema Tributário da Constituição de 1988. In: DANTAS, Bruno et al. Constituição de 1988: o Brasil 20 anos depois. Brasília: Senado Federal, 2008.

${ }^{134}$ ROCHA, Antonio Sérgio Carvalho. As Partes e o Todo: congresso nacional, executivo e o problema do orçamento no Brasil. In: Perspectivas, São Paulo, v. 34, jul.dez. 2008, pp. 55-78, p. 64.
} 
não aprovação de projetos de lei orçamentária encaminhados pelo Executivo ao Legislativo no prazo devido. ${ }^{135}$

Sem entrar nas particularidades e atualidade de cada controvérsia, os constituintes optaram por resolvê-las, seja por meio da proliferação de centros de poder com atribuições equiparadas, seja por meio de reserva de lei, complementar ou não, simples ou qualificada. Soluções de compromissos inteligíveis, por exemplo, pela categoria dos "acordos incompletamente teorizados", de Cass Sunstein. ${ }^{136}$

Enfim, a solução orçamentária esboçada traduziu-se em um novo arranjo institucional $^{137}$, sob as luzes da dicotomia eficiência macroeconômica e participação, na qual os parlamentares possuem limitada influência na fixação de despesas públicas ${ }^{138}$, devem contribuir precipuamente nas macroalocações orçamentárias por meio da fixação de prioridades do setor público nacional e o Legislativo passou a ter consideráveis poderes na fiscalização da execução do orçamento público ${ }^{139}$.

No entanto, se por um lado houve pouco interesse na elaboração do texto constitucional no tópico orçamentário e certa homogeneidade de propostas e visões por parte dos constituintes interessados acerca dos limites e potencialidades da atividade financeira do Estado, a dinâmica política relativa ao orçamento público foi uma das que mais sofreu com o fenômeno da juridificação da política, isto é, as diversas forças políticas passaram a traduzir em termos jurídicos seus interesses na conquista de direitos e recursos públicos, ante a falta de um bloco político hegemônico. ${ }^{140}$

\footnotetext{
${ }^{135}$ AFONSO, José Roberto. Memória da Assembléia Constituinte de 1987/88: as finanças públicas. In: Revista do BNDES, Rio de Janeiro, v. 6, n. 11, 1999, pp. 21-48, p. 28.

${ }^{136}$ SUNSTEIN, Cass. Legal Reasoning and Political Conflict. Nova York: Oxford University Press, 1996, pp. 35-61.

137 ROCHA, Antonio Sérgio Carvalho. As Partes e o Todo: congresso nacional, executivo e o problema do orçamento no Brasil. In: Perspectivas, São Paulo, v. 34, jul.dez. 2008, pp. 55-78, p. 69.

${ }^{138}$ Segundo Gilberto Bercovici e Luís Fernando Massoneto, a Constituição Financeira restou "blindada", de modo a excluir o orçamento das deliberações públicas em prol da persecução de metas de política monetária (BERCOVICI, Gilberto. MASSONETTO, Luís Fernando. A Constituição Dirigente Invertida: a blindagem da constituição financeira e a agonia da constituição económica. In: Boletim de Ciências Económicas, Coimbra, v. 49, 2006, pp. 57-77, p. 71).

${ }^{139}$ Em perspectiva oposta a de Bercovici e Massoneto, Ricardo Lobo Torres apresenta o seguinte balanço da Constituição Orçamentária brasileira: "Mas a CF 88 falhou em algumas questões básicas. Transplantou das Constituições da Alemanha e da França, países parlamentaristas, a idéia de uma lei de diretrizes orçamentárias, que não poderia se aclimatar, como realmente não se aclimatou, no ambiente presidencialista brasileiro, o que tem sido em boa parte uma das causas do atraso na aprovação do orçamento. Deu poderes excessivos à Comissão Mista de Senadores e Deputados e, em geral, ao próprio Congresso Nacional para a apresentação de emendas ao projeto de orçamento." (TORRES, Ricardo Lobo. O Orçamento na Constituição Orçamentária. Rio de Janeiro: Renovar, 1995, p. 291)

${ }^{140}$ NOBRE, Marcos. Indeterminação e Estabilidade. In: Novos Estudos, São Paulo, n. 82, nov. 2008, pp. 97-106, p. 101.
} 
Nesse cenário, a lógica das disputas políticas no processo constituinte perpassou a multiplicação de demandas, pautas e temas; evitar vetos; e engessar juridicamente os acordos alcançados. Logo, como mecanismo de estabilização de expectativas políticas, limitou-se ao máximo o espaço de contendas por fundos públicos, ao estabelecer cotas constitucionais para determinadas finalidades, por intermédio da vinculação de receitas tributárias para determinadas despesas públicas. Em suma, "a lógica subjacente é a de que o sistema político é incapaz de produzir maiorias sólidas e constantes, de modo que o essencial do orçamento (reservas constitucionais e pagamento da conta de juros) tem de ficar fora da disputa por recursos." 141

A resultante desse processo é a disputa política por recursos públicos ocorrer por margens (microalocações). Noutras palavras, “A implementação da ordem econômica e da ordem social da Constituição de 1988 ficaram restritas, assim, às sobras orçamentárias e financeiras do Estado." ${ }^{142}$ Desse modo, há entraves no desenho institucional da divisão funcional dos poderes para fins de concretização da dignidade humana, pois a relação desse princípio com a constituição econômica exige a realização de uma concepção de democracia econômica e social, para além de uma noção de "mínimo existencial" atrelada unicamente a direitos e garantias individuais. Aliás, segundo Gilberto Bercovici, “A liberdade e a igualdade políticas da democracia representam também uma exigência material de igualdade e a sua sobrevivência depende de um maior grau de homogeneidade social." ${ }^{143}$

Outro fator não devidamente equacionado no processo constituinte, principalmente por conta de seu ineditismo na experiência brasileira, fora a afirmação política do Poder Judiciário o qual foi alçado à posição de importante ator político na esfera pública, notadamente nos campos da efetivação de direitos fundamentais e no funcionamento da democracia brasileira. Desenhou-se, portanto, um novo quadro institucional às instituições do sistema de justiça brasileiro. Segundo Maria Tereza Sadek, em razão da constituição efetiva do Poder Judiciário como poder de Estado e da proliferação de demandas sócio-econômicas traduzidas na forma de direitos subjetivos, o Estado-Juiz projetou-se ao centro da vida política e social. ${ }^{144}$

\footnotetext{
${ }^{141}$ NOBRE, Marcos. Indeterminação e Estabilidade. In: Novos Estudos, São Paulo, n. 82, nov. 2008, pp. 97-106, p. 101.

${ }^{142}$ BERCOVICI, Gilberto; MASSONETTO, Luís Fernando. A Constituição Dirigente Invertida: a blindagem da constituição financeira e a agonia da constituição económica. In: Boletim de Ciências Económicas, Coimbra, v. 49, 2006, pp. 57-77, p. 71.

${ }^{143}$ BERCOVICI, Gilberto. Constituição Econômica e Dignidade da Pessoa Humana. In: Revista da Faculdade de Direito da Universidade de São Paulo, v. 102, jan./dez. 2007, pp. 457-467, p. 462.

${ }^{144}$ SADEK, Maria Tereza Aina. Poder Judiciário: uma nova construção institucional. In: Revista da Escola Nacional da Magistratura, Brasília, a. VII, n. 6, nov. 2012, pp. 392-411, p. 396.
} 
Por evidente, essa nova condição acarretou em relevantes reflexos orçamentários e financeiros, positivos e negativos. De saída, observa-se ser o Judiciário uma instância política reativa, e não propositiva, de modo que o desempenho da função jurisdicional toma pouco em conta os custos envolvidos e a finitude de recursos públicos ${ }^{145}$, o que pode levar a distorções de justiças alocativa e distributiva, assim como a certa descrença quanto à sua capacidade institucional de contribuir como instância criadora ou gestora de políticas públicas.

De todo modo, os desdobramentos institucionais do modelo de separação dos poderes delineado pela ANC serão retomados especificamente quanto ao objeto da presente investigação no terceiro capítulo deste trabalho, de maneira a contrastar os propósitos constituintes e a atuação do direito financeiro em movimento no contexto posterior a 1988.

Em encerramento a esta subseção e ao capítulo, importa descrever e refletir a respeito da Constituição Financeira como positivada na CR/88. Na síntese de Ricardo Lobo Torres, a Constituição Financeira brasileira compreende a Constituição Tributária (Capítulo I: Do Sistema Tributário Nacional), a Constituição Financeira Propriamente Dita (repartição de receitas tributárias entre os entes políticos e sistema monetário nacional - Capítulos I, Seção VI, e Capítulo II, Seção I) e a Constituição Orçamentária (Capítulo II, Seção I - Dos Orçamentos). ${ }^{146}$

Para as finalidades do presente trabalho, o esforço argumentativo se centrará no capítulo referente às finanças públicas, por sua vez subpartido em (i) normas gerais e (ii) orçamento público, especificamente localizados entre os artigos 163 a 169 da CR/88.

Em relação às normas gerais de direito financeiro, trata-se de uma contribuição do processo constituinte de 1946, de autoria de Aliomar Baleeiro, a partir da necessidade de incluir-se o direito financeiro como ramo jurídico cuja competência legislativa pertencia à União. Nesse sentido, está em jogo a própria autonomia normativa da disciplina jurídica. Assim, a norma geral é aquela de foro nacional com aptidão para vincular juridicamente todos os entes federativos. De todo modo, revela-se prudente afastar uma definição apriorística da categoria de "norma geral", uma vez que esta é retoricamente contingenciada como um

\footnotetext{
${ }^{145}$ Cita-se, como exemplo, o seguinte excerto do voto divergente e vencedor do Ministro Marco Aurélio: "Senhor Presidente, não me preocupa o problema de caixa do erário, como também não preocupa aos demais Ministros que integram esta Corte. Preocupa-me, sim, a manutenção, a intangibilidade da ordem constitucional." (BRASIL. SUPREMO TRIBUNAL FEDERAL. Recurso Extraordinário 150.764, Plenário, Rel. Min. Sepúlveda Pertence, Red. p/ ac. Marco Aurélio, j. 16.12.1992, Publ. DJ em 02.04.1993, pp. 1497-1588, p. 1542)

${ }^{146}$ TORRES, Ricardo Lobo. A Constitucionalização do Direito Financeiro. In: SOUZA NETO, Claudio Pereira de; SARMENTO, Daniel (coords.). A Constitucionalização do Direito: fundamentos teóricos e aplicações específicas. Rio de Janeiro: Lumen Juris, 2007, pp. 971-974.
} 
problema de hermenêutica constitucional. Porém, de acordo com Rubens Gomes de Sousa, cabe falar em finalidade e limite de uma norma geral. Em termos teleológicos, as normas gerais de direito financeiro servem para fixar "as consequências necessárias dos preceitos constitucionais em matéria financeira, de forma a assegurar a atuação efetiva e uniforme de tais preceitos". Por outro lado, o limite da norma geral é a auto-organização e o autogoverno decorrentes da autonomia federativa. ${ }^{147}$

Nesse sentido, o artigo 24, I, da CR/88, garante à União, Estados e ao Distrito Federal legislar concorrentemente a respeito de direito financeiro, ao passo que o art. 163 do texto constitucional prevê a necessidade de leis complementares que disponham acerca de finanças públicas, dívidas públicas, operações de crédito, fiscalização financeira e funções das instituições oficiais de crédito da União. ${ }^{148}$ Além disso, o art. 165, $§ 9^{\circ}$, da CR/88, também estatui reserva de lei complementar para o desenho normativo das leis orçamentárias e normas de gestão financeira e patrimonial da administração pública, bem como sobre a criação de fundos públicos. ${ }^{149}$

Ainda no campo das normas gerais, o art. 164 da CR/88 prevê as diretrizes de relacionamento entre o Banco Central e o Tesouro Nacional, especialmente como forma de evitar a denominada "conta-movimento" e respectivos reflexos em termos de endividamento público e efeito inflacionário. Igualmente, o dispositivo prevê a competência exclusiva da União para emitir moeda.

Por outro lado, na seção "Dos orçamentos”, há cinco artigos os quais podem ser assim sistematizados, em ordem crescente: as leis orçamentárias (LOA, LDO e PPA); o processo legislativo orçamentário e as atribuições da CMO; as normas jurídicas (princípios e regras) e critérios econômicos reguladores da elaboração e execução do orçamento público, assim como a previsão dos créditos adicionais; a obrigatoriedade de repasse de duodécimos como

\footnotetext{
${ }^{147}$ SOUSA, Rubens Gomes de. Normas Gerais do Direito Financeiro. In: Revista de Direito Administrativo, Rio de Janeiro, v. 37, jan. 1954, pp. 12-34, p. 15.

148 "Assim, temos: a) há competência concorrente em matéria de direito financeiro entre União, Estados e Distrito Federal; b) à União somente compete a expedição de normas gerais; c) a edição destas não exclui a competência dos Estados; d) caso não haja legislação federal, os Estados terão competência plena; e e) sobrevindo legislação federal, a estadual, se existente, terá sua eficácia suspensa, por conflito com a norma geral" (OLIVEIRA, Regis Fernandes de. Curso de Direito Financeiro. 3 ed. são Paulo: Revista dos Tribunais, 2010, p. 94).

${ }^{149} \S 9^{\circ}$ Cabe à lei complementar: I - dispor sobre o exercício financeiro, a vigência, os prazos, a elaboração e a organização do plano plurianual, da lei de diretrizes orçamentárias e da lei orçamentária anual; II - estabelecer normas de gestão financeira e patrimonial da administração direta e indireta bem como condições para a instituição e funcionamento de fundos; III - dispor sobre critérios para a execução equitativa, além de procedimentos que serão adotados quando houver impedimentos legais e técnicos, cumprimento de restos a pagar e limitação das programações de caráter obrigatório, para a realização do disposto no $§ 11$ do art. 166.
} 
corolário da autonomia financeira; e o controle das despesas correntes com pessoal ativo ou inativo.

Em relação à normatividade constitucional, Ricardo Lobo Torres identifica a ordenação da principiologia orçamentária de acordo com dois pilares, a liberdade e a segurança. ${ }^{150}$ No entanto, o enfoque a ser aqui dado residirá nos princípios da legalidade orçamentária e anualidade, assim como nas regras da exclusividade, universalidade, unidade e equilíbrio orçamentário, haja vista as respectivas relevâncias para o objeto da pesquisa e referenciais positivados no texto constitucional. De plano, a premissa básica é o orçamento ser, em si mesmo, uma instituição constitucional e a necessidade do desenvolvimento concreto do ciclo orçamentário estar em consonância aos imperativos, diretivas e princípios da ordem constitucional. ${ }^{151}$

No tocante ao princípio $^{152}$ da legalidade, trata-se de pedra basilar na afirmação constitucional do orçamento público no Estado de Direito, tendo em vista que a lei, na qualidade de ato normativo formalmente emanado do Poder Legislativo, é condição de existência do orçamento. Nesse sentido, a atividade financeira do Estado também se vincula à juridicidade dos atos administrativos, por força do art. 37 da CR/88. Na vertente da reserva de lei, o princípio condiciona a previsão de receitas, realização de despesas e o planejamento fiscal por parte da Administração Pública à existência prévia de uma lei em sentido formal. Em perspectiva estrita, implica em vedação ao início de programas ou projetos não incluídos na lei orçamentária anual, nos termos do art. 167, I, da CR/88. Em suma, "a legalidade cria vinculação permanente para a Administração, quanto ao cumprimento das despesas autorizadas e fins do planejamento, afora o dever de máxima observância dos critérios entabulados para cada dotação ou crédito orçamentário". ${ }^{153}$

Com guarida no art. 165, III, da CR/88, o princípio da anualidade nada mais é do que a expressão jurídica da periodicidade do orçamento público, à luz da dinamicidade dos fenômenos financeiros. Logo, possui uma dúplice funcionalidade: definir a vigência da lei

\footnotetext{
${ }^{150}$ TORRES, Ricardo Lobo. O Orçamento na Constituição. Rio de Janeiro: Renovar, 1995, p. 137 e ss.

${ }^{151}$ CORTI, Horacio Guillermo. Derecho Constitucional Presupuestario. 2 ed. Buenos Aires: Abeledo-Perrot, 2011, p. 63

${ }^{152}$ No ponto, concorda-se com Luís Eduardo Schoueri para quem a legalidade é enunciado normativo do qual se haurem regras e princípios: "Tem-se no Princípio da Legalidade um bom exemplo de enunciado que permite se extraiam regras como a autoridade não poder exigir um tributo na falta de lei prevendo-o, sem que ali se esgote o dispositivo, já que há um mandamento de otimização (princípio), igualmente baseado no mesmo dispositivo, que implica esperar-se que o legislador descreva, com a maior precisão possível, as circunstâncias que darão ensejo à tributação." (SCHOUERI, Luís Eduardo. Direito Tributário. 5 ed. São Paulo: Saraiva, 2015, p. 291)

${ }^{153}$ TORRES, Heleno Taveira. Direito Constitucional Financeiro: teoria da constituição financeira. São Paulo: RT, 2014, pp. 374-375.
} 
orçamentária, uma vez que esta possui destinação temporária, nos termos do art. $2^{\circ}$ do DL $4.657 / 42$ (Lei de Introdução às normas do Direito Brasileiro) ${ }^{154}$; e torná-la provisória, vedando sua ultratividade jurídica, tirante os efeitos jurídicos voltados aos exercícios financeiros subsequentes com o fito de planejamento, como se depreende, por exemplo, do art. $167, \S 1^{\circ}$, da $\mathrm{CR} / 88^{155}$. Igualmente, há uma motivação política na periodicidade do orçamento público na medida em que "o Legislativo deve exercer o controle político sobre o Executivo pela renovação anual da permissão para a cobrança dos tributos e a realização dos gastos, sendo inconcebível a perpetuidade ou a permanência da autorização para a gestão financeira." ${ }^{156}$ Por fim, o exercício financeiro guarda coincidência com o ano civil, ex vi previsão no art. 34 da Lei 4.320/64.

A regra da exclusividade vigora no ordenamento pátrio desde 1926, a partir de alteração formal do art. $34, \S 1^{\circ}$, da Constituição da República de 1891 . Nesse sentido, o art. $165, \S 8^{\text {o157}}$, da CR/88, veda a veiculação de dispositivo estranho à previsão e à fixação de despesas na LOA, excepcionadas a autorização para abertura de créditos suplementar ou operações de crédito. Almeja-se, portanto, evitar prática corrente na Velha República relativa à inclusão das chamadas "caudas orçamentárias", isto é, direitos e deveres alheios à orçamentação, em prol da clareza e transparência da peça orçamentária. ${ }^{158}$

A propósito, veio a lume o $\$ 5^{\circ}$ do art. 165 da $\mathrm{CR} / 88$ do qual se extrai a regra da universalidade, segundo a qual "o orçamento deve conter todas as receitas e despesas da União, de qualquer natureza, procedência ou destino, inclusive a dos fundos, dos empréstimos e dos subsídios." ${ }^{159}$ Nesse sentido, devem constar na lei orçamentária todas as estimativas de receitas patrimonias e derivadas, assim como a fixação das despesas de todos os Poderes da União, da fundos, órgãos e entidades da Administração Pública direta e indireta e os investimentos das empresas estatais nas quais a União detenha a maioria do capital social votante. A finalidade é a clareza e exatidão da atividade financeira do ente federativo.

Um dos desdobramentos do caráter duplo (formal-material) da lei orçamentária

\footnotetext{
${ }^{154}$ Art. $2^{\underline{0}}$ Não se destinando à vigência temporária, a lei terá vigor até que outra a modifique ou revogue.

$155 \S 1^{\circ}$ Nenhum investimento cuja execução ultrapasse um exercício financeiro poderá ser iniciado sem prévia inclusão no plano plurianual, ou sem lei que autorize a inclusão, sob pena de crime de responsabilidade.

${ }^{156}$ TORRES, Ricardo Lobo. Art. 165. In: CANOTILHO, J. J. Gomes et al. Comentários à Constituição do Brasil. São Paulo: Saraiva/Almedina, 2013, p. 1763.

$157 \S 8^{\circ}$ A lei orçamentária anual não conterá dispositivo estranho à previsão da receita e à fixação da despesa, não se incluindo na proibição a autorização para abertura de créditos suplementares e contratação de operações de crédito, ainda que por antecipação de receita, nos termos da lei.

158 SILVA, José Afonso da. Curso de Direito Constitucional Positivo. 31 ed. São Paulo: Malheiros, 2008, pp. 739-740.

${ }^{159}$ TORRES, Ricardo Lobo. O Orçamento na Constituição. Rio de Janeiro: Renovar, 1995, p. 205.
} 
consistiu na existência simultânea de dois orçamentos, um das receitas e outro das despesas, culminando na complexificação dos processos de elaboração, execução e controlabilidade do orçamento. Assim, em esforço para reunificar os orçamentos e permitir a participação efetiva do Poder Legislativo no ciclo orçamentário, o art. $165, \S 5^{\circ}$, da CR/88, preconiza que a LOA compreende o orçamento fiscal, de investimento e da seguridade social, em oposição ao sistema de orçamentos múltiplos e descentralizados instaurado no regime militar. Igualmente, ao fazer referência a três leis de conteúdo e finalidades diversas no art. 165, I, II e III, da $\mathrm{CR} / 88$, não se excepcionaliza a regra em comento. Na verdade, a unidade do orçamento, como corolário da unicidade da personalidade jurídica da União, significa o dever de coerência entre as diversas peças orçamentárias ao longo do tempo, de modo a assegurar correlação entre os meios (recursos públicos) e os fins (objetivos da República).

Por fim e envolto em maior polêmica, resta o equilíbrio orçamentário. De fato, sua própria existência é razão de controvérsia na doutrina do Direito Financeiro, porquanto sua aceitação pressupõe escolhas ideológicas. ${ }^{160}$ Para Ricardo Lobo Torres, a CR/88 fez a opção pelo princípio do equilíbrio orçamentário, sob a reserva do possível, sendo que aquele tem a aptidão de informar todos os demais princípios orçamentários. Assim, "Equilíbrio orçamentário é a equalização de receitas e gastos, harmonia entre capacidade contributiva e legalidade e entre redistribuição de rendas e desenvolvimento econômico." 161

Noutra banda, Gilberto Bercovici é enfático no sentido de que a CR/88 não contempla o referido princípio, pois isso implicaria em inviabilizar o projeto desenvolvimentista inaugurado pelo pacto constituinte. ${ }^{162}$ Nessa linha, Heleno Taveira Torres afirma que "Não há na Constituição brasileira qualquer dispositivo que manifeste algo no sentido da afirmação do ‘equilíbrio orçamentário' como um princípio do nosso ordenamento." ${ }^{163}$ Para essa corrente, permanece o ideal de controle e aprimoramento do gasto público, contudo, a depender da conjuntura econômica e dos objetivos do Estado, o balanço orçamentário anual pode apresentar superávits ou déficits fiscais e nominais. Logo, persegue-se a sustentabilidade financeira das contas públicas, categoria essa que incorpora a temporalidade de investimentos

\footnotetext{
${ }^{160}$ Para uma crítica do padrão normativo do Direito Financeiro inspirado no ideário do liberalismo econômico e fundamentado no princípio do equilíbrio orçamentário, veja-se: MASSONETTO, Luís Fernando. O Direito Financeiro no capitalismo contemporâneo: a emergência de um novo padrão normativo. $145 \mathrm{f}$. Tese de Doutorado - Faculdade de Direito, Universidade de São Paulo, São Paulo, 2006, pp. 106 e ss.

${ }^{161}$ TORRES, Ricardo Lobo. Art. 165. In: CANOTILHO, J. J. Gomes et al. Comentários à Constituição do Brasil. São Paulo: Saraiva/Almedina, 2013, p. 1765.

${ }_{162}$ BERCOVICI, Gilberto. Desigualdades Regionais, Estado e Constituição. São Paulo: Max Limonad, 2003, p. 209.

${ }^{163}$ TORRES, Heleno Taveira. Direito Constitucional Financeiro: teoria da constituição financeira. São Paulo: RT, 2014, p. 384.
} 
e programação de despesas públicas para além de um exercício financeiro. ${ }^{164}$

Passada a estrutura principiológica do sistema orçamentário nacional, torna-se cabível esboçar uma propedêutica das leis orçamentárias. Nesses termos, prevê-se na ordem constitucional um planejamento fiscal por "afunilamento", desde o PPA à LOA, todas com status de lei ordinária. ${ }^{165}$ A esse respeito, no processo constituinte, com inspiração na experiência alemã e francesa, "prevaleceu uma hierarquia entre os instrumentos, de forma que emendas às leis inferiores (Orçamento e créditos adicionais) deveriam ser compatíveis com o que dispõem as leis superiores (do plano plurianual e das diretrizes orçamentárias anuais)". ${ }^{166}$

Em relação ao PPA, trata-se de lei para fins de planejamento estratégico do governo no médio prazo, por meio do estabelecimento de diretrizes, objetivos e metas da Administração Pública Federal para as despesas de duração continuada e de capital e suas decorrentes, conforme disposto no art. $165, \S 1^{167}$, da $\mathrm{CR} / 88$. Ademais, visa à promoção da integração nacional, de acordo com o art. 43 da CR/88, assim como guia orientador na elaboração dos planos e programas nos âmbitos nacional, regional e setorial, nos termos do art. $165, \S 4^{\mathrm{o} 168}$, da CR/88.

No tocante à LDO, observa-se uma funcionalidade operacional no curto prazo relativa ao planejamento estratégico esboçado no PPA, uma vez que este possui as seguintes funções constitucionais encartadas nos arts. $165, \S 2^{\mathrm{o}}{ }^{169}$, e $169, \S 1^{\circ}, \mathrm{II}^{170}$, da CR/88: (i) estabelece as metas e prioridades da administração, incluindo as despesas de capital para o exercício subsequente; (ii) orienta a elaboração da LOA; (iii) dispõe sobre as alterações na legislação

\footnotetext{
${ }^{164}$ Cf. SCAFF, Fernando Facury; ROCHA, Francisco Sergio Silva. Equilíbrio Orçamentário e Sustentatibildiade Financeira: anotações sobre o Brasil. In: Revista dos Tribunais, São Paulo, v. 925, nov. 2012, pp. 175-201.

${ }^{165}$ SCAFF, Fernanco Facury. Como a Sociedade Financia o Estado para a Implementação dos Direitos Humanos no Brasil. In: SCAFF, Fernando Facury (org.). Constitucionalismo, Tributação e Direitos Humanos. Rio de Janeiro: Renovar, 2007, p. 34.

${ }^{166}$ AFONSO, José Roberto. Memória da Assembléia Constituinte de 1987/88: as finanças públicas. In: Revista do BNDES, Rio de Janeiro, v. 6, n. 11, 1999, pp. 21-48, p. 42.

${ }^{167} \S 1^{\circ}$ A lei que instituir o plano plurianual estabelecerá, de forma regionalizada, as diretrizes, objetivos e metas da administração pública federal para as despesas de capital e outras delas decorrentes e para as relativas aos programas de duração continuada.

${ }^{168} \S 4^{\circ}$ Os planos e programas nacionais, regionais e setoriais previstos nesta Constituição serão elaborados em consonância com o plano plurianual e apreciados pelo Congresso Nacional.

${ }^{169} \S 2^{\circ}$ A lei de diretrizes orçamentárias compreenderá as metas e prioridades da administração pública federal, incluindo as despesas de capital para o exercício financeiro subseqüente, orientará a elaboração da lei orçamentária anual, disporá sobre as alterações na legislação tributária e estabelecerá a política de aplicação das agências financeiras oficiais de fomento.

${ }^{170} \S 1^{\circ}$ A concessão de qualquer vantagem ou aumento de remuneração, a criação de cargos, empregos e funções ou alteração de estrutura de carreiras, bem como a admissão ou contratação de pessoal, a qualquer título, pelos órgãos e entidades da administração direta ou indireta, inclusive fundações instituídas e mantidas pelo poder público, só poderão ser feitas: (...)II - se houver autorização específica na lei de diretrizes orçamentárias, ressalvadas as empresas públicas e as sociedades de economia mista.
} 
tributária; (iv) fixa a política de aplicação das agências financeiras oficiais de fomento; e (v) autoriza a concessão de qualquer vantagem ou aumento de remuneração de servidores, a criação de cargos, empregos, funções ou alteração na estrutura de carreira, bem como a admissão e contratação de pessoal a qualquer título na Administração, tirante para as empresas estatais e sociedades de economia mista. No plano infraconstitucional, o art. $4^{\circ}$ da LRF trouxe diversas inovações em relação à funcionalidade da LDO, como, por exemplo, a inclusão de anexos de metas e riscos fiscais, de modo que este diploma legal tem importância destacada no controle da execução orçamentária.

$\mathrm{Na}$ visão dos constituintes, teríamos como leis inferiores no âmbito do planejamento fiscal a LOA e os créditos adicionais. A primeira é responsável pela previsão das receitas e despesas para o exercício financeiro a que pretende regular, de forma a evidenciar a política econômica financeira e o programa de trabalho do Governo, em consonância ao disposto no art. $2^{\circ}$ da Lei $4.320 / 64^{171}$. Também conforme o art. $22^{172}$ do diploma precitado, além do projeto de LOA, o Poder Executivo deve encaminhar mensagem ao Poder Legislativo na qual contenha exposição circunstanciada da situação econômico-financeira do ente federativo, com a devida fundamentação da política fiscal e justificação do plexo de receitas e despesas.

Informadas pelas regras orçamentárias de unidade e universalidade, a LOA é composta por três sub-orçamentos: o fiscal que abarca todos os Poderes da União, fundos, órgãos e entidades e tem a função de demonstrar a totalidade de suas receitas e despesas; o de investimentos com alcance a todas as sociedades de economia mista e empresas públicas federais, sendo suficiente a demonstração dos gastos com investimentos e o lastro que os financiará; e o da seguridade social, demonstrando a dinâmica de financiamento dos direitos à saúde, previdência social e assistência social sob a responsabilidade da União.

Assim como a LDO, a LOA ganhou novas incumbências com o advento do art. $5^{\circ}$ da LRF, à luz de um paradigma de gestão fiscal responsável, principalmente (i) a existência de um anexo demonstrando a compatibilidade da programação de despesas com o Anexo de Metas Fiscais da LDO vigente; (ii) uma reserva de contigência para fazer frente a riscos e

\footnotetext{
${ }^{171}$ Art. $2^{\circ}$ A Lei do Orçamento conterá a discriminação da receita e despesa de forma a evidenciar a política econômica financeira e o programa de trabalho do Govêrno, obedecidos os princípios de unidade universalidade e anualidade.

${ }^{172}$ Art. 22. A proposta orçamentária que o Poder Executivo encaminhará ao Poder Legislativo nos prazos estabelecidos nas Constituições e nas Leis Orgânicas dos Municípios, compor-se-á: I - Mensagem, que conterá: exposição circunstanciada da situação econômico-financeira, documentada com demonstração da dívida fundada e flutuante, saldos de créditos especiais, restos a pagar e outros compromissos financeiros exigíveis; exposição e justificação da política econômica-financeira do Govêrno; justificação da receita e despesa, particularmente no tocante ao orçamento de capital;
} 
eventos fiscais imprevistos; e (iii) um demonstrativo regionalizado sobre os impactos fiscais e respectivas medidas de compensação decorrentes de renúncias de receitas e aumento de despesas obrigatórias de caráter continuado.

Demais, os créditos adicionais são aqueles veiculados por lei, decreto ou MP consistentes em autorizações de despesas públicas não computadas ou insuficientemente dotadas nos créditos orçamentários previstos na LOA, nos termos do art. 40 da Lei 4.320/64. Nesse sentido, os créditos adicionais também se submetem ao processo legislativo orçamentário, nos moldes do que ocorre com a LOA. Segundo o art. $46^{173}$ da lei indigitada, o ato de abertura do crédito deve indicar a importância, a espécie e a classificação da despesa pública, com a maior exatidão possível e observância das regras da clareza e exatidão orçamentárias, bem como da vedação contida no art. 167, VII ${ }^{174}$, da CR/88.

Com espeque no art. 41 da Lei 4.320/64, os créditos adicionais classificam-se em suplementares, especiais e extraordinários. Os créditos suplementares são aqueles destinados ao reforço orçamentário de dotações pré-existentes. Por sua vez, os créditos especiais são aqueles em que não há dotação orçamentária específica, logo se abre uma nova programação. Por fim, os créditos extraordinários servem para atender despesas urgentes e imprevistas, em caso de guerra, comoção intentestina e calamidade pública.

Além disso, os créditos suplementares e os especiais são abertos por decreto executivo, após autorização em lei, assim como dependem da existência e indicação prévia de recursos disponíveis para embasar a despesa, com a devida justificativa, conforme os artigos 42 e 43 do diploma legal supracitado e art. 167, V, da CR/88. Ressalte-se que se consideram fontes, desde que não comprometidas, o superávit financeiro apurado em balanço patrimonial do exercício anterior; os provenientes de excesso de arrecadação; os resultantes de anulação parcial ou total de dotações orçamentárias ou de créditos adicionais, autorizados em Lei; e o produto de operações de crédito autorizadas, em forma que juridicamente possibilite ao Poder Executivo realizá-las.

Noutra perspectiva, os créditos extraordinários pertencem ao sistema constitucional de crises, portanto excepcionam a vedação de MP que verse sobre lei orçamentária, à luz do art.

\footnotetext{
173 Art. 46. O ato que abrir crédito adicional indicará a importância, a espécie do mesmo e a classificação da despesa, até onde fôr possível.

${ }^{174}$ Art. 167. São vedados: (...) VII - a concessão ou utilização de créditos ilimitados;
} 
62, $§ 1^{\circ}$, I, “d”, da CR/88 ${ }^{175}$. Nesses termos, o art. $167, \S 3^{\circ}$, da $\mathrm{CR} / 88$, preconiza que "A abertura de crédito extraordinário somente será admitida para atender a despesas imprevisíveis e urgentes, como as decorrentes de guerra, comoção interna ou calamidade pública, observado o disposto no art. 62." Logo, essa espécie de crédito dispensa a indicação prévia de recursos, o que furta ao Poder Legislativo, em alguma medida, a noção do impacto fiscal da medida na execução orçamentária.

Além da MP, há intensa controvérsia doutrinária acerca da recepção do art. 44 da Lei 4.320/64, uma vez que este permite ao Poder Executivo abrir crédito extraordinário por meio de decreto executivo, desde que informe imediatamente ao Parlamento. Na verdade, a questão importa na medida em que abre ou não a possibilidade dos governos locais (Estados, Distrito Federal e Municípios) fazerem uso desse instrumento orçamentário excepcional. Nada obstante a complexidade do tema não permita seu tratamento nesta pesquisa, acredita-se que o referido dispositivo não foi recepcionado por falta de compatibilidade material com a ordem constitucional vigente, haja vista os arranjos institucionais entre os Poderes (valorização da função do Poder Legislativo na nova solução ao "problema do orçamento") e os entes federativos (concentração na União da competência administrativa para lidar com guerras, comoções internas e calamidade pública, por meio de instrumentos próprios, como intervenções federais, estados de defesa e sítio, imposto extraordinário de guerra e a Política Nacional de Proteção e Defesa Civil prevista na Lei 12.608/2012 ${ }^{176}$ ) postos na CR/88.

Igualmente, torna-se cabível abordar a vigência temporária e respectiva possibilidade de prorrogação dos créditos adicionais. De acordo com o art. 45 da Lei 4.320/64, "Os créditos adicionais terão vigência adstrita ao exercício financeiro em que forem abertos, salvo expressa disposição legal em contrário, quanto aos especiais e extraordinários.” Porém, o art. 167, §2º, da $\mathrm{CR} / 88$, restou por reduzir ainda mais a discricionariedade dos ordenadores de despesa, ao dispor que a viabilidade da prorrogação se restringe ao caso em que "o ato de autorização for promulgado nos últimos quatro meses daquele exercício, caso em que, reabertos nos limites de seus saldos, serão incorporados ao orçamento do exercício financeiro subseqüente."

\footnotetext{
${ }^{175}$ Art. 62. Em caso de relevância e urgência, o Presidente da República poderá adotar medidas provisórias, com força de lei, devendo submetê-las de imediato ao Congresso Nacional. $\S 1^{\circ}$ É vedada a edição de medidas provisórias sobre matéria: I - relativa a: (...) d) planos plurianuais, diretrizes orçamentárias, orçamento e créditos adicionais e suplementares, ressalvado o previsto no art. $167, \S 3^{\circ}$;

${ }^{176}$ BRASIL. PRESIDÊNCIA DA REPÚBLICA. Lei 12.608, de 10 de abril de 2012. Institui a Política Nacional de Proteção e Defesa Civil - PNPDEC; dispõe sobre o Sistema Nacional de Proteção de Defesa Civil SINPDEC e o Conselho Nacional de Proteção e Defesa Civil - CONPDEC; autoriza a criação de sistema de informações e monitoramento de desastres; altera as leis 12.340 , de 1 de dezembro de $2010,10.257$, de 10 de juhlo de 2011, 6.766, de 19 de dezembro de 1979, 8.239, de 4 de outubro de 1991, e 9.394, de 20 de dezembro de 1996; e dá outras providências. Diário Oficial da União, Seção 1, Publ. em 11.04.2012, p. 1.
} 
Em síntese, os créditos adicionais são instrumentos adjetivos à orçamentação, de modo a adaptar o planejado à realidade fiscal. Nesse sentido, em um paradigma de governo informado por uma gestão fiscal responsável, a utilização de créditos orçamentários alheios aos previstos na LOA deve ser sempre residual, ainda mais diante da possibilidade de transposição, remanejamento ou transferência de recursos de uma categoria de programação para outra ou de um órgão para outro, desde que com prévia autorização legislativa, nos termos do art. 167, VI, da CR/88. 


\section{A JURISDIÇÃO CONSTITUCIONAL E A JUSTICIABILIDADE EM ABSTRATO DAS DECISÕES ORÇAMENTÁRIAS}

A tensão moderna entre democracia e constitucionalismo permite a revisitação constante da legitimidade democrática das comunicações produzidas pelos órgãos encarregados da jurisdição constitucional. Por outro lado, soberania popular e direitos humanos também se relacionam em tensão, de modo que a legitimidade das cortes constitucionais para tutelar os direitos fundamentais pressupõe a possibilidade de controle das decisões judiciais pelo titular da soberania, o Povo.

Assim, a temática da função comunicativa da jurisdição constitucional revela-se complexa, tendo em vista o contexto relativo à produção de redes discursivas pelas instituições que compõem o quadro constitucional das democracias hodiernas. Isso porque a complexidade emana dos fundamentos e limites autodeterminados por uma comunidade política referente ao órgão responsável pelo controle de constitucionalidade do ordenamento jurídico.

Intenciona-se na presente seção da pesquisa saber se a construção jurisprudencial do STF acerca do controle abstrato de constitucionalidade referente a normas orçamentárias na atual ordem constitucional se mostrou coerente e adequada em nível argumentativo, sob a ótica das teorias da argumentação jurídica.

Por conseguinte, este capítulo apresenta o seguinte expediente argumentativo. Em um primeiro momento, torna-se cabível a promoção de uma análise comparativa sobre a legitimidade democrática da jurisdição constitucional, à luz das teorias da argumentação em suas dimensões analítica e retórica. Nesse ponto, com o aporte teórico desenvolvido a partir da Tópica Moderna, como formulada por Theodor Viehweg, pretende-se averiguar a possibilidade e conveniência de arranjos institucionais que permitam a produção de discursos racionais e adequados na seara de uma Corte Constitucional às exigências democráticas.

Vistos os limites e as condições de possibilidade de um discurso emanado da práxis jurisdicional, também é necessário estabelecer o quadro metodológico responsável pela análise das manifestações constantes no acórdão da Medida Cautelar na ADI 4.048, de relatoria do Ministro Gilmar Mendes. A visão do Direito como emaranhado de redes discursivas pressupõe um arcabouço analítico-conceitual compatível com os objetivos deste trabalho. Para isso, tomam-se como pontos de partida expedientes metodológicos já utilizados 
em um conjunto de pesquisas jurídicas, cujos objetos de trabalho são correlatos à empresa acadêmica ora desenvolvida.

Após, o estudo se centrará na ADI-MC precitada, visando a dar resposta sobre o problema secundário lançado neste capítulo. Ao fim e ao cabo, espera-se haurir as razões de decidir do julgado e verificar, ainda, a formação de um precedente com aptidão para orientação e estabilização comunicativa de expectativas sociais.

Nesse sendeiro, começa-se pelo passado, isto é, a exposição dos entendimentos prévios do $\mathrm{STF}$, sob a vigência da $\mathrm{CR} / 88$, de modo a entender em que medida o processo de índole objetiva analisado representou uma revisão de jurisprudência. Depois, pretende-se abordar panoramicamente o julgamento, de modo a não perder a deliberação colegiada em face dos votos condutores das correntes vencedora e vencida, sob as lentes da teoria da argumentação jurídica de Neil MacCormick e da moderna Retórica da Escola de Mainz.

Por fim, com escopo na dimensão normativa do estudo da dogmática jurídica e aos fundamentos extraídos das análises de discursos trazidos à baila pelas teorias da argumentação jurídica, haverá um exame crítico do julgamento em tela, mormente duas questões: (i) o cabimento de ADI interposta em face de MP, cujo objeto era a abertura de crédito extraordinário, uma vez que a lei orçamentária teria natureza jurídica de lei formal de efeitos concretos; e (ii) a competência do Poder Judiciário para avaliar a concorrência dos requisitos da "urgência", "relevância" e "despesas imprevisíveis e emergenciais" do diploma legislativo impugnado, inclusive depois da MP ser convertida em lei pelo Congresso Nacional.

\subsection{Análise Comparativa sobre a Legitimidade Democrática da Jurisdição Constitucional: entre a teoria da argumentação standard e a retórica moderna ${ }^{177}$}

Inicialmente, lança-se mão do aporte teórico desenvolvido pela Tópica moderna, a partir da obra de Theodor Viehweg. É dizer: torna-se cabível o estilo de pensamento tópico para perquirir o problema em discussão, na medida em que um esquema de perguntas e

\footnotetext{
${ }^{177}$ Parcela dos argumentos a seguir apresentados foi também objeto de exposição no Grupo de Trabalho "Teorias da Justiça, da Decisão e da Argumentação Jurídica" no XXV Encontro Nacional do CONPEDI, realizado na Universidade de Brasília, em Brasília, de 06 a 09 de julho de 2016. Nesse sentido, torna-se imperativo agradecer a atenção e os comentários recebidos no encontro.
} 
respostas, que leve em conta uma concepção de justiça situacional e provisória, revela-se particularmente producente para tratar de aporias típicas da seara democrática, como, por exemplo, a legitimidade democrática das cortes constitucionais.

Embora sejam todas legatárias de uma tradição retórica advinda da antiguidade grecoromana e relida pelas lentes de Viehweg, há dificuldades para a emergência de um discurso unitário acerca do estado da arte da argumentação jurídica, dado a constatação de diferenças conceituais básicas no âmbito desse conjunto teorético.

Logo, opta-se pelo agrupamento dessas teorias em duas correntes, a teoria da argumentação padrão ${ }^{178}$ (standard ou mainstream) e a retórica moderna, de modo a explicitar as divergências em nível de racionalidade discursiva. Ressalta-se que se adjetiva o primeiro grupo como padrão, à luz de seu grau de aceitação no "senso comum teórico dos juristas"179, isto é, na qualidade de modelo preponderante para a análise da racionalidade dos discursos da práxis jurídica.

Ademais, ressalte-se que a tópica é intimamente ligada ao estudo da cultura jurídica de uma determinada comunidade política - no caso, a brasileira -, pois se trata da investigação de lugares-comuns que consistem em ferramentas compartilhadas da vida social, as quais, por sua vez, permitem a própria compreensão da práxis jurídica. ${ }^{180}$

\footnotetext{
${ }^{178}$ Cf. MACCORMICK, Neil. Argumentação Jurídica e Teoria do Direito. São Paulo: Martins Fontes, 2006, p. 10 e ss. Acerca da autocontenção metodológica dessa matriz teórica, vejam-se as ponderações de André Rufino do Vale: "De seu objeto de investigação são excluídos os distintos aspectos institucionais e as variações de estilo argumentativo que podem ser observadas e verificadas, em perspectiva comparada, em diferentes sistemas jurídicos, como a tradição dos tribunais britânicos de permitir que cada um de seus membros possa proferir publicamente um discurso individual com suas próprias razões de decidir, e a prática dos tribunais europeus de deliberar a portas fechadas e divulgar sua decisão em texto único que de modo algum revele qualquer divergência interna entre seus membros. MacCormick opta por estudar especificamente o processo de justificação das decisões (e não o processo de sua descoberta), com enfoque, portanto, no raciocínio judicial tal como apresentado textualmente nas publicações oficiais, e que no estilo argumentativo característico do sistema britânico (na Inglaterra, no País de Gales e na Escócia) é desenvolvido de modo individualizado, seja na sentença do juiz singular de primeira instância ou em forma discursiva por um membro de tribunal. Ele não deixa de mencionar, porém, a importância que podem ter os diferentes modos de argumentação presentes em diversos sistemas do direito comparado como campo de estudo de uma teoria da argumentação que pretenda oferecer parâmetros indicadores de mudanças na performance argumentativa de juízes e tribunais." (VALE, André Rufino do. Argumentação Constitucional: um estudo sobre a deliberação nos tribunais constitucionais. 415 f. Tese de Doutorado - Faculdade de Direito, Universidade de Brasília/Universidade de Alicante, BrasíliaDF/Alicante-ES, 2015, p. 14)

${ }^{179}$ Cf. WARAT, Luís Alberto. O Senso Comum Teórico dos Juristas. In: FARIA, José Eduardo (org.). A Crise do Direito numa Sociedade em Mudança. Brasília: UnB, 1988.

${ }^{180}$ Cf. BALKIN, Jack M. A Night in the Topics: the reason of legal rhetoric and the rhetoric of legal reason. In: BROOKS, P.; GERWIRTH, P. (org.). Law's Stories: Narrative and Rhetoric in the Law. New Haven: Yale University Press, 1996, pp. 211-224.
} 


\subsubsection{A tópica de Theodor Viehweg e as teorias da argumentação jurídica}

Theodor Viehweg pode ser considerado o principal responsável pelo ressurgimento do interesse da comunidade jurídica pela tópica e por esforços atualizadores da retórica, a partir de inspiração oriunda da antiguidade clássica. A despeito de sua importância para a filosofia do Direito, sua produção intelectual mostrou-se errática e sem maiores pretensões de sistematização ou completude na forma de uma teoria generalizante. Em Tópica $e$ Jurisprudência, obra apresentada como tese de livre docência pelo alemão, tem-se o estudo mais abrangente formulado por Viehweg sobre uma nova forma de conceber o Direito proporcionado pela tópica.

Nesse sentido, convém delinear, sem pretensões exaurientes, as principais linhas do pensamento do filósofo do direito alemão, porquanto a partir delas se constituíram as correntes teóricas preocupadas com a racionalidade da argumentação jurídica na contemporaneidade.

De plano, pode-se ler a obra referida como uma reação aos pressupostos epistêmicos das teorias jurídicas de matriz positivista em voga à época. Nesse sentido, rechaça-se a noção de um sistema jurídico dedutivo e fechado, em que a subsunção direta do fato à norma fosse a metodologia hegemônica para a formação de juízos jurídicos. Noutras palavras, o projeto oitocentista de um Direito completo e fechado é contraposto ao estilo de pensamento da tópica antiga, ou seja, há um resgate de uma técnica constatável na filosofia greco-romana em face de uma pretensão de cientificidade cartesiana no Direito.

Segundo Viehweg, não se observa o direito como um resultado derivado de um sistema dedutivo estrito. Noutras palavras, a adjudicação judicial é melhor explicada por intermédio de antigas técnicas de comunicação social em detrimento de concepções modernas de ciência. Assim, uma decisão legal estaria baseada em uma associação de reflexões que "circundam" cada caso, tendo em vista os diferentes pontos de vista e argumentos (topoi) usualmente conectadas com a situação em questão. ${ }^{181}$

Com base na constatação do baixo poder explicativo de pensar o Direito como sistema lógico-dedutivo, Viehweg volta-se para os seguintes campos de investigação: a dialética como

\footnotetext{
${ }^{181}$ SOBOTA, Katharina. System and Flexibility in Law. In: Argumentation, Holanda, v. 5, n. 3, ago. 1991, pp. 275-282, p. 276.
} 
a arte de trabalhar com opiniões opostas; e a prudência ${ }^{182}$ como saber. Ademais, há uma contraposição entre os conceitos de episteme (demonstração por causas necessárias) e techne (produção de reflexões razoáveis sobre um objeto social).

Nesse quadro, com respaldo em uma reconstrução teórica das filosofias de Aristóteles e Cícero em relação à retórica, assim como a análise da jurisprudentia romana e os resultados de sua renovação no medievo, o filósofo alemão chega à tópica como estilo de pensamento que enfoca na solução de problemas concretos e a partir deles o saber jurídico se desenvolve.

Na qualidade de técnica do pensamento problemático, a tópica pretende fornecer indicações de saídas para situações aporéticas, isto é, aquelas não passíveis de eliminação. ${ }^{183}$ Para Tércio Sampaio Ferraz Jr., "pensar topicamente significa manter princípios, conceitos, postulados, com um caráter problemaico, na medida em que jamais perdem sua qualidade de tentativa," ${ }^{184}$ de modo que as figuras doutrinárias permanecem abertas e prestam a função de "fórmulas de procura" de solução de conflitos.

Para o jurista germânico, "problema é toda questão que aparentemente permite mais de uma resposta e que requer necessariamente um entendimento preliminar, de acordo com o qual toma o aspecto de questão que há que levar a sério e para a qual há de buscar uma resposta como solução." 185

No entanto, ressalta-se que a proposta de Viehweg não representa um abandono à sistematização, mas sim oferece um sistema diferente com uma estrutura diversa, a partir de topos. Na verdade, o problema se ordena dentro de um sistema, a diferença, então, reside no acento em que se dá no bojo do relacionamento entre sistema e problema. Logo, ao acentuar o viés problemático da relação, o sistema passa a servir de ponto de auxílio para a chegada à solução do conflito. ${ }^{186}$

\footnotetext{
182 “É opinião geral que a especificidade do homem prudente é o ser capaz de deliberar corretamente sobre o que é bom e vantajoso para si próprio, não se baseando num ponto de vista parcial (...) mas, de uma maneira geral, procurando quais são as coisas que, por exemplo, levam a uma vida feliz. Uma prova do que dizemos é o fato de chamarmos prudente àqueles que o são num domínio determinado, quando são capazes de calcular com justeza tendo em vista alcançar um fim particular digno de prêmio nas espécies de atividade em que não intervém a arte. Daí resulta que, também num sentido geral, será um homem prudente aquele que é capaz de deliberar de uma maneira geral.” (ARISTÓTELES. Obra Jurídica. Trad. Carlos Rodrigues. São Paulo: Ícone, 1997, p. 103)

${ }^{183}$ VIEHWEG, Theodor. Tópica e Jurisprudência. Trad. Tércio Sampaio Ferraz Júnior. Brasília: Departamento de ImprensaNacional, 1979, p. 33.

${ }^{184}$ FERRAZ JUNIOR, Tércio Sampaio. Introdução. In: VIEHWEG, Theodor. Tópica e Jurisprudência. Trad. Tércio Sampaio Ferraz Júnior. Brasília: Departamento de Imprensa Nacional, 1979, p. 3.

${ }^{185}$ VIEHWEG, Tópica e Jurisprudência. Trad. Tércio Sampaio Ferraz Júnior. Brasília: Departamento de ImprensaNacional, 1979, p. 34.

${ }_{186}$ VIEHWEG, Tópica e Jurisprudência. Trad. Tércio Sampaio Ferraz Júnior. Brasília: Departamento de Imprensa Nacional, 1979, pp. 34-35.
} 
Tendo em vista que a função do topos é contribuir a uma discussão de problemas, esse lugar-comum recebe seu significado a partir dessa dinâmica dialógica. Por conseguinte, os topoi devem ser entendidos a partir de uma perspectiva funcional, isto é, como possibilidades de orientação e condução do raciocínio jurídico. ${ }^{187}$

Igualmente, Viehweg divide a tópica em primeiro e segundo graus. No primeiro, há uma dinamicidade resultante de um modo de pensar que só pode contar com panoramas fragmentários. Há, portanto, uma perquirição heurística acerca de premissas que sejam objetivamente adequadas e profícuas, com aptidão para se desdobrarem em uma linha argumentativa que leve a uma resposta ao problema em discussão.

No segundo grau, o sistema adquire um aspecto mais estático, não obstante sua constante abertura para o novo. Produzem-se, então, um repertório de pontos de vista preparados a priori que serão mobilizados concretamente para atender às necessidades do problema. Chama-se justamente esse procedimento de instrumentalização do catálogo de topoi, de "tópica de segundo grau".

A tópica também pode ser subdivida em geral e específica, dado que o topos é justamente a ponte de ligação entre a juridicidade e a realidade social globalmente considerada. A generalidade denota a abrangência de problemáticas pertinentes a variados campos do saber. Ou seja, a tópica geral pressupõe uma universalidade de aplicação a problemas que aparecem em todas as áreas, conquanto a tópica particular cinge-se a um conjunto restrito de problemas. ${ }^{188}$

Além disso, torna-se imperativo mencionar os escritos posteriores do pensador em relação à Jurisprudência, com o intuito de apontar como se trabalhou posteriormente a tópica moderna, a partir da recepção da teoria na comunidade jurídica.

Nesse sentido, ponto fulcral é a relação entre dogmática jurídica, Teoria do Direito e Filosofia do Direito. Para o alemão, da Filosofia do Direito decorre uma Teoria do Direito, que, por sua vez, propicia condições, na qualidade de teoria fundamental, para uma dogmática jurídica. ${ }^{189}$ Existe, então, uma relação de mútua dependência entre essas três esferas da

\footnotetext{
187 VIEHWEG, Tópica e Jurisprudência. Trad. Tércio Sampaio Ferraz Júnior. Brasília: Departamento de Imprensa Nacional, 1979, p. 38.

${ }_{188}$ ROESLER, Claudia Rosane. Theodor Viehweg e a Ciência do Direito: tópica, discurso, racionalidade. 2 ed. Belo Horizonte: Arraes, 2013, p. 141.

${ }^{189}$ VIEHWEG, Theodor. Sobre la relación entre filosofia del derecho, teoria del derecho y dogmatica juridical In: VIEHWEG, Theodor. Tópica y filosofía del derecho. 2 ed. Trad. De Jorge M. Seña. Barcelona: Gedisa, 1997, pp. 15-28, passim.
} 
Jurisprudência.

A partir de uma filosofia do direito como investigação de base e atuante na Jurisprudência como infraestrutura da teoria do direito, pode-se conceber a tópica como um esquema de perguntas e respostas o qual pode ser investigado por intermédio de diferentes estruturas, a zetética e a dogmática.

A zetética dá ênfase nas perguntas e apresenta uma função eminentemente cognitiva. Assim, as tópicas de primeiro e segundo graus passam a ser passíveis de questionamento. Permite-se, portanto, a preservação dos topoi com seu caráter hipotético, problemático, tentativo e questionável.

Por outro lado, a dogmática acentua a esfera da opinião e tenciona a construção de uma dimensão estruturante do comportamento social. Logo, a aceitação do destinatário da comunicação elimina a possibilidade, ao menos temporariamente, de se problematizar as próprias premissas, as quais atuam como dogmas inatacáveis.

Em síntese, "O pensamento dogmático está vinculado à opinião e à formação de opinião, ao tempo que o zetético liga-se à dissolução das opiniões por intermédio da investigação e seu pressuposto básico é a dúvida."190

Demais disso, convém explicitar que o saber jurídico demanda uma complementariedade necessária entre os enfoques zetético e dogmático, caso haja pretensões de completude. Segundo Claudia Roesler, pode-se ler a situação da seguinte forma: "para Viehweg, o conhecimento jurídico completo compõe-se de investigações dogmáticas e zetéticas que se estruturam respectivamente como uma dogmática jurídica que contém em si uma teoria material do Direito e uma filosofia do Direito que analisa o discurso jurídico."191

Sendo assim, Theodor Viehweg pode ser interpretado como o precursor das modernas teorias da argumentação jurídica, na medida em que concebe como objeto de pesquisa jurídica a comunicação. À luz da ligação entre retórica e Jurisprudência, explicita-se o caráter situacional do pensamento jurídico, tendo em vista sua vinculação com a práxis, de modo que verticalizar esse relacionamento lança luzes sobre as estruturas discursivas do Direito e

\footnotetext{
${ }^{190}$ ROESLER, Claudia Rosane. Theodor Viehweg e a Ciência do Direito: tópica, discurso, racionalidade. 2 ed. Belo Horizonte: Arraes, 2013, p. 190.

${ }^{191}$ ROESLER, Claudia Rosane. O papel de Theodor Viehweg na fundação das teorias da argumentação jurídica. In: Revista Eletrônica Direito e Política, Programa de Pós-Graduação Stricto Sensu em Ciência Jurídica da UNIVALI, Itajaí, v. 4, n. 3, 3o. quadrimestre de 2009, pp. 36-54, p. 51.
} 
respectivos condicionantes. ${ }^{192}$

Nesse quadro, "o controle racional seria realizado, portanto, a partir do próprio discurso e dos procedimentos adotados pelos seus partícipes. Nenhum discurso, nesse sentido, goza de uma presunção de correção absoluta desvinculada de sua situação de produção."193 Possibilita-se, assim, uma racionalidade, alheia a fundamentos metafísicos e verdades absolutas, que auxilie na seleção de parâmetros adequados para a ação humana.

Eis a base do empreendimento que será levado a cabo pelas teorias da argumentação jurídica na segunda metade do século $\mathrm{XX}$, notadamente no campo do agir juridicamente relevante.

Com Theodor Viehweg, a racionalidade do discurso jurídico passa a integrar a pauta do dia, porquanto a despeito de ter uma postura cética em relação à possibilidade de certeza científica do conhecimento jurídico, o jurista alemão acredita na viabilidade de comparação entre discursos e seleção de premissas, de modo que um exame de racionalidade é possível, a partir do convencimento e da importância dos discursos. ${ }^{194}$

Nesses termos, as conclusões dos raciocínios jurídicos serão sempre relativos e provisórios, contudo não se pode tachar o pensamento de Viehweg de relativista, pois não há advocacia pela arbitrariedade, e sim pelo controle dos discursos judiciais em nível de racionalidade.

Por fim, também se compartilha da chave analítica de Claudia Roesler, segundo a qual o jurista alemão pode ser considerado um precursor do constitucionalismo contemporâneo, porquanto há no relacionamento de mútua dependência entre dogmática jurídica, Teoria do Direito e Filosofia do Direito, conforme já exposto, uma ênfase nas dimensões argumentativa e valorativa do jurídico, de modo a aproximá-lo da teoria constitucional contemporânea. ${ }^{195}$

Diante dessa chave de leitura, verifica-se o arcabouço teórico relativo à Tópica

\footnotetext{
${ }^{192}$ ROESLER, Claudia Rosane. O papel de Theodor Viehweg na fundação das teorias da argumentação jurídica. In: Revista Eletrônica Direito e Política, Programa de Pós-Graduação Stricto Sensu em Ciência Jurídica da UNIVALI, Itajaí, v. 4, n. 3, 3o. quadrimestre de 2009, pp. 36-54, p. 47.

${ }^{193}$ ROESLER, Claudia Rosane. O papel de Theodor Viehweg na fundação das teorias da argumentação jurídica. In: Revista Eletrônica Direito e Política, Programa de Pós-Graduação Stricto Sensu em Ciência Jurídica da UNIVALI, Itajaí, v. 4, n. 3, 3o. quadrimestre de 2009, pp. 36-54, p. 48.

${ }^{194}$ ROESLER, Claudia Rosane. O papel de Theodor Viehweg na fundação das teorias da argumentação jurídica. In: Revista Eletrônica Direito e Política, Programa de Pós-Graduação Stricto Sensu em Ciência Jurídica da UNIVALI, Itajaí, v. 4, n. 3, 3o. quadrimestre de 2009, pp. 36-54, p. 48.

${ }^{195}$ ROESLER, Claudia Rosane. Theodor Viehweg: ¿un constitucionalista adelantado a su tiempo? Trad. Ángel Espinosa Gadea. In: Doxa: cuardernos de filosofia del Derecho, Alicante, Espanha, n. 29, 2006, pp. 295-318, p. 296.
} 
moderna formulado por Viehweg como importante referencial para as práticas dos juristas, notadamente "ao apontar a alta relevância jurídica e política da Constituição, sem simplificar a problemática de sua interpretação e sem desconsiderar a presença dos valores e dos princípios como pontos de partida e de chegada em tal prática". ${ }^{196}$

\subsubsection{Teoria da argumentação jurídica standard}

Como visto na seção anterior, as teorias da argumentação jurídica hodiernas são legatárias da retomada do discurso judicial como objeto de pesquisa do Direito. Do mesmo modo, também se alega que esse movimento teórico assumiu caráter oposicionista às concepções positivistas então predominantes, assim como é atribuível o adjetivo de precursores a Theodor Viehweg, Chaim Perelman e Stephen Toulmin. ${ }^{197}$

Em momento posterior, tornaram-se expoentes dessa corrente doutrinária, inter alia, Robert Alexy, Neil MacCormick e Manuel Atienza, de modo que aqui se extrairão dos pensamentos desses autores pontos comuns, de maneira a articular uma concepção mais ou menos precisa de quais elementos formariam uma matriz teórica representante da argumentação jurídica standard ou mainstream. Seguidamente, haverá uma contraposição dessas ideias ao que se convencionou chamar de "Escola de Mainz", como representante das pesquisas modernas acerca da retórica jurídica.

Segundo Alexy, uma teoria da argumentação jurídica racional contemporânea toma da tópica de Viehweg alguns aspectos, em particular tem-se que "em áreas onde não há motivos para a justificação não é necessário deixar o campo aberto para a tomada irracional de decisões, e também para a crença de que existe uma conexão conceitual próxima entre a idéia de justificação e da discussão racionais.",198

Por outro lado, aponta-se como limites do tópica, tal como desenvolvida por Theodor Viehweg, os seguintes pontos: (i) subestimar a importância da lei, da dogmática e dos

\footnotetext{
${ }^{196}$ Tradução livre. No original: “al apuntar la alta relevância jurídica y política de la constitución, sin simplificar la problemática de su interpretación y sin desconsiderar la presencia de los valores y los princípios con puntos de partida y de llegada em tal práctica" (ROESLER, Claudia Rosane. Theodor Viehweg: ¿un constitucionalista adelantado a su tiempo? Trad. Ángel Espinosa Gadea. In: Doxa: cuardernos de filosofia del Derecho, Alicante, Espanha, n. 29, 2006, pp. 295-318, p. 318).

${ }^{197}$ Cf. ATIEnZA, Manuel. As Razões do Direito: Teorias da Argumentação Jurídica. 3 ed. Trad. Maria Cristina Guimarães Cupertino. São Paulo: Landy, 2003.

${ }^{198}$ ALEXY, Robert. Teoria da Argumentação Jurídica. Trad. Zilda Hutchinson Schild Silva. São Paulo: Landy, 2001, p. 33.
} 
precedentes; (ii) análise insuficientemente vertical dos argumentos jurídicos; e (iii) imprecisão do arcabouço conceitual referente à discussão. ${ }^{199}$

Igualmente, Robert Alexy desenvolve a viabilidade de um discurso jurídico racional, com respaldo em um discurso prático geral. Nesse sentido, apresenta-se a tese do caso especial, a qual se funda em três premissas: (i) as discussões jurídicas se pautam em questões práticas da vida social; (ii) a exigência de correção se apresenta como constrição ao discurso especial; e (iii) a discussão no campo jurídico se dá nos limites estritos do tipo descrito. ${ }^{200}$

A especialidade é caracterizada pela existência de uma série de condições restritivas aplicáveis somente à argumentação jurídica, resumíveis na vinculação à lei, aos precedentes e à dogmática. Noutras palavras, essas constrições levam a um sistema de regras e formas específicas de argumentar na arena jurídica. ${ }^{201}$

Noutra banda, a exigência de correção do discurso jurídico se diferencia em relação ao discurso prático geral, porquanto não demanda uma universalidade da afirmação normativa em caráter absoluto, mas sim uma justificação racional no contexto da validade da ordem jurídica vigente.

Neil MacCormick também argumenta no mesmo sentido, na medida em que advoga pela possibilidade de universalização das razões justificadoras das decisões, tendo em conta o caráter argumentativo do Direito e o Estado de Direito. Isso porque para que fatos ou motivos particulares sejam considerados razões de decidir justificadoras, "eles têm que ser subsumíveis a um princípio relevante de ação universalmente afirmado, mesmo que a proposição universal respectiva seja reconhecidamente excepcionável (defeasible)". ${ }^{202}$ Ademais, alega-se que essa necessidade de justificação se aplica de forma geral à argumentação prática, atingindo, por especialidade, o campo da argumentação jurídica.

No tocante à interação entre Moral e Direito, as teorias da argumentação jurídica pressupõem a possibilidade de uma integração discursiva da comunidade jurídica, na medida em que a força racional de um argumento poderia ser aceita por todos. Noutras palavras, essa matriz teórica concebe a possibilidade de uma fundamentação de juízos éticos do ponto de

\footnotetext{
${ }^{199}$ ALEXY, Robert. Teoria da Argumentação Jurídica. Trad. Zilda Hutchinson Schild Silva. São Paulo: Landy, 200, p. 33.

${ }^{200}$ ALEXY, Robert. Teoria da Argumentação Jurídica. Trad. Zilda Hutchinson Schild Silva. São Paulo: Landy, 2001, p. 212.

${ }^{201}$ ALEXY, Robert. Teoria dos Direitos Fundamentais. Trad. Virgílio Afonso da Silva. São Paulo: Malheiros, 2008 , p. 548.

${ }^{202}$ MACCORMICK, Neil. Retórica e o Estado de Direito. Trad. Conrado Hübner Mendes. Rio de Janeiro: Elsevier, 2008, p. 131.
} 
vista cognitivo.

Para Manuel Atienza, nos termos de sua proposta de uma filosofia do direito pensada para o mundo latino, "um modelo de teoria do Direito pragmaticamente útil e culturalmente viável nos nossos países podem consistir em uma combinação destes três ingredientes: método analítico, objetivismo moral e efetividade social."203

Aqui, importa explorar o conceito de objetivismo moral defendido pelo jurista espanhol, segundo o qual para se rechaçar um não cognitivismo ético que desborde para o relativismo, deve-se adotar como alternativa um objetivismo moral mínimo traduzível na tese de que os juízos morais incorporam uma pretensão de correção e razões últimas no âmbito da argumentação prática, ainda que falíveis.

Para o jurista espanhol, isso não implica em irracionalidade de um discurso arbitrário ou em uma pretensão de verdade absoluta. Na verdade, defende-se que é possível uma discussão racional acerca de valores, os quais atribuímos a certas ações e estados de coisas, para deliberar coletivamente sobre a boa vida. Do mesmo modo, a pretensão de correção não desborda para o ceticismo ou o absolutismo, porquanto exige a exposição de juízos ao discurso racional. ${ }^{204}$

Trata-se de um passo além do defendido por Theodor Viehweg, uma vez que no raciocínio de Atienza está pressuposta uma ligação necessária entre Moral e Direito, dado o caráter dual deste (positividade e idealidade), como condição de satisfação dos pressupostos de um constitucionalismo pós-positivista. Logo, o discurso jurídico submete-se a maiores constrições para fazer jus ao atributo da racionalidade no paradigma do pós-positivismo.

\subsubsection{A Construção Retórica do Direito}

A visão de um Direito construído por meio da retórica tem seu eixo de desenvolvimento na chamada "Escola de Mainz", tendo em vista a influência direta de

\footnotetext{
${ }^{203}$ Tradução livre: "Un modelo de teoria del Derecho pragmaticamente útil y culturalmente viable um nuestros países bien podrea consistir en combinar estos três ingredientes: método analítico, objetivismo moral e implantación social" (ATIENZA, Manuel. Una Propuesta de Filosofía del Derecho para el Mundo Latino In: Doxa, Cuadernos de Filosofía del Derecho, n. 30, 2007, pp. 661-663, p. 663).

${ }^{204}$ ATIENZA, Manuel. Ni positivismo jurídico ni neoconstitucionalismo: uma defensa de constitucionalismo postpositivista. In: Observatório da Jurisdição Constitucional, Brasília, IDP, a. 7, n. 2, jul./dez. 2014, pp. 1-24, p. 17.
} 
Theodor Viehweg, catedrático de filosofia do Direito dessa Universidade alemã. Segundo Katharina Sobota, pode-se tomar o Direito como um sistema de atividades humanas dinâmico e complexo, cujos caracteres são (i) a ligação com a própria história; (ii) a incerteza do comportamento dos indivíduos; e (iii) a permanente alteração no ambiente. Em suma, o Direito pode ser visto como uma das atividades retóricas que formam a realidade humana. ${ }^{205}$

Nessa seara, a retórica como campo de pesquisa pode ser dividida em três modalidades: a material, a prática e a analítica. ${ }^{206}$ Nesse sentido, a estratégia de tripartição se revela adequada para evitar recair em reducionismos em relação aos usos semânticos do termo "retórica". Nesse sentido, a retórica material se refere a uma cosmovisão, a retórica prática se traduz em estratégia de persuasão; e a retórica analítica se revela em um instrumento de análise de discursos. ${ }^{207}$

A partir desses três significados, pode-se afirmar que a retórica se ocupa da produção das redes semióticas, sendo sua principal vantagem comparativa a outros esforços semióticos a potencialidade de verificação empírica de suas alegações.

Assim, a pesquisa moderna em retórica se divide em três vertentes: a pesquisa de base (Ballweg e Viehweg); a análise do discurso (Perelman e Schreckenberguer); e o direito como um sistema social que se constitui de forma retórica (Ballweg e Sobota). Demais, o principal insight desse campo de pesquisa seria de que tudo é mais imponderável e paradoxal do que esperado pelo otimismo científico. ${ }^{208}$

Igualmente, o maior sucesso da retórica moderna foi a representação de um catálogo provisório das condições fundamentais para responder às questões de quando e em que circunstâncias a rede do direito tece fios entrelaçados. No entanto, remanesce como fracasso explicativo a informação sobre padrões individuais de comportamento legal em níveis razoáveis de exatidão. ${ }^{209}$

Por outro lado, percebe-se que a pretensão analítica da retórica é distinta da

\footnotetext{
${ }^{205}$ SOBOTA, Katharina. System and Flexibility in Law. In: Argumentation, Holanda, v. 5, n. 3, ago. 1991, pp. 275-282, p. 277.

${ }^{206}$ BALLWEG, Ottmar. Retórica analítica e direito. Trad. João Maurício Adeodato. Mimeo. No original em alemão: Rhetorik und Vertrauen In: Kritik und Vertrauen: Festschift für Peter Schneider zum 70 Geburtstag. Frankfurt a.M.: Anton Hain Verlag, 1990, pp. 34-44, passim.

${ }^{207}$ REIS, Issac. Análise empírico-retórica do Discurso Constitucional: uma contribuição metodológica à pesquisa de base em direito. In: RODRIGUES, Horário Wanderlei et alii (coord.). Direito, Educação, Ensino e Metodologia Jurídicos. Florianópolis: CONPEDI, 2014, p. 79.

${ }^{208}$ SOBOTA, Katharina. The Rhetorical Construction of Law. In: International Journal for the Semiotics of Law, v. 5, n. 1, fev. 1992, pp. 39-54, pp. 41-42.

209 SOBOTA, Katharina. The Rhetorical Construction of Law. In: International Journal for the Semiotics of Law, v. 5, n. 1, fev. 1992, pp. 39-54. p. 42.
} 
apresentada pelas teorias de argumentação standard, pois aquela renuncia à universalização imposta por uma pretensão de racionalidade estrita. Logo, a inspiração ética da retórica moderna é de cunho cético, pois há uma suspensão do juízo ético, uma vez que este não consegue se fundamentar, à luz de um objetivismo moral.

Contudo, importa ressaltar que a postura ética não implica em um relativismo do ponto de vista moral nem que o Direito como sistema social se produz de maneira arbitrária. $\mathrm{Na}$ verdade, a racionalidade simplesmente não é uma questão estruturante, pois se mostra contingenciada retoricamente, tendo em conta que o auditório será sempre específico à situação retórica apresentada.

Em síntese, "Para satisfazer essas exigências de análise e averiguabilidade paga-se um alto preço: a renúncia completa a proposições normativas dotadas de conteúdo. Por outro lado, é também certo que os resultados analíticos servem indiretamente à práxis. ${ }^{, 210}$ Noutras palavras, o cético não se permite fazer uma afirmação ou negação dogmática sobre qualquer coisa, dado que uma visão de mundo não consegue se impor em termos argumentativos em face da multiplicidade de outras opções éticas.

Assim sendo, importa destacar que se de um lado a pretensão de analiticidade não permite uma postura relativista por parte do ceticismos, também é bastante discutível a associação do ceticismo, em sua versão contemporânea, a uma adesão à modernidade burguesa da cultura ocidental por outro lado, ou seja, o ceticismo não exige necessariamente uma postura de indiferença ou de suporte ao status quo. Na verdade, a postura perante o mundo de um cético dá condições para uma cultura da tolerância. ${ }^{211}$

\subsubsection{Democracia e corte constitucional}

A despeito de encontrarem uma origem comum no pensamento jurídico de Theodor Viehweg, as matrizes teóricas da argumentação jurídica padrão e da retórica moderna apresentam explicações e justificações distintas para a configuração do ordenamento jurídico, tendo em vista as nuances teoréticas já explicitadas.

\footnotetext{
${ }^{210}$ BALLWEG, Ottmar. Retórica analítica e direito. Trad. João Maurício Adeodato. Mimeo. No original em alemão: Rhetorik und Vertrauen In: Kritik und Vertrauen: Festschift für Peter Schneider zum 70 Geburtstag. Frankfurt a.M.: Anton Hain Verlag, 1990, pp. 34-44, p. 39.

${ }^{211}$ ADEODATO, João Maurício. Ética e Retórica: para uma teoria da dogmática jurídica. São Paulo: Saraiva, 2002, pp. 317 e ss.
} 
Assim, ambas as perspectivas possuem como pano de fundo o Estado de Direito e a relação intrínseca entre Direito e Democracia, contudo ao partirem de premissas distintas chegam a resultados também diversos. Importa aqui estabelecer um paralelo entre as propostas de colocação de uma Corte Constitucional no seio do ambiente democrático.

Por acreditarem na racionalidade do discurso jurídico, ambas as vertentes possuem como eixo propositivo a possibilidade dos discursos judiciais e concebem a conveniência de um órgão encarregado da resolução de conflitos constitucionais, a partir do controle de constitucionalidade.

Por um lado, as teorias da argumentação standard advogam no sentido de que o caráter racional da jurisprudência emana de sua conformidade às condições, critérios ou regras que o constituem, tendo como conteúdo mínimo a exigência de consistência, de racionalidade instrumental e a verdade das afirmações empíricas usadas.

Nesse sentido, é concebível uma Corte Constitucional que realize um controle procedimental e substancial da ordem jurídica, à luz da rigidez e da supremacia constitucionais. Não há o que falar, portanto, em desafio a um Estado de Direito ${ }^{212}$, uma vez que é justamente a premissa de um governo de leis que fundamenta o discurso judicial sobre a Constituição.

Nesses termos, a jurisdição constitucional permite a conjugação de uma teoria da argumentação jurídica com o discurso de direitos fundamentais, sendo este um procedimento argumentativo que se traduz na obtenção de resultados constitucionalmente corretos. Noutras palavras, "por meio das regras e formas da argumentação prática geral e da argumentação jurídica, a argumentação no âmbito dos direitos fundamentais que ocorre sobre essa base é racionalmente estruturada.",213

Acerca da racionalidade do processo de institucionalização de uma jurisdição constitucional, Robert Alexy é particularmente assertivo, o que justifica sua transcrição a seguir:

\footnotetext{
212 "No que tange ao Estado de Direito, as pessoas podem ter, antecipadamente, razoável certeza a respeito das regras e padrões segundo os quais sua conduta será julgada, e sobre os requisitos que elas devem satisfazer para dar validade jurídica às suas transações" (MACCORMICK, Neil. Retórica e o Estado de Direito. Trad. Conrado Hübner Mendes. Rio de Janeiro: Elsevier, 2008, p. 22).

${ }^{213}$ ALEXY, Robert. Teoria dos Direitos Fundamentais. Trad. Virgílio Afonso da Silva. São Paulo: Malheiros, 2008, pp. 573-574.
} 
A insegurança quanto aos resultados do discurso no âmbito dos direitos fundamentais leva à necessidade de decisões dotadas de autoridade. Se a maioria parlamentar não deve controlar a si mesma, o que significaria ser juiz em causa própria, sobra apenas a alternativa de alguma forma de jurisdição constitucional. $\mathrm{O}$ fato de um tribunal constitucional não apenas argumentar, mas também decidir, nada tem de irracional. De forma geral, vale a idéia de que a razão prática pode ser realizada apenas no âmbito de um sistema jurídico que vincule, de forma racional, argumentação e decisão. ${ }^{214}$

Sendo assim, uma Corte Constitucional realiza seu papel na democracia constitucional, a partir da limitação de autoridades majoritárias, de modo que a regra das maiorias pode encontrar óbice nos direitos das minorias que dissentem do majoritariamente consentido. Trata-se da função contramajoritária da jurisdição constitucional para a concretização do discurso dos direitos fundamentais. Além disso, segundo essa perspectiva teórica, a democracia constitucional não assume o ponto de partida de que cada instância decisória deve se basear em critérios majoritários para se legitimar. ${ }^{215}$

Na opinião de Daniel Farber e Suzanna Sherry, alguns órgão políticos são mais responsivos à opinião majoritária do que outros, o que não é surpreendente, tendo em vista a complexidade das democracias hodiernas. Portanto, é um equívoco demandar um nível homogêneo de accountability democrática de cada instituição política, pois o relevante é considerar a legitimidade democrática do sistema estatal como um todo. ${ }^{216}$

Por sua vez, a retórica moderna considera a democracia como uma rede de discussões, de modo que democracia e retórica se condicionam. Nas palavras de Ottmar Ballweg, a retórica deve sua origem às condições institucionais da democracia, conquanto a democracia deve à retórica o adestramento dos participantes no debate. Sendo assim, o intercâmbio argumentativo de opiniões se refere ao campo da retórica e a confiança nesta seara encontra seus fundamentos nas relações democráticas. ${ }^{217}$

No pensamento de Katharina Sobota, a constrição do decoro incidente sobre o discurso jurídico pressupõe atualmente o encontro de orador e auditório em condições e procedimentos democráticos. Assim, a institucionalização da retórica em uma democracia

\footnotetext{
${ }^{214}$ ALEXY, Robert. Teoria dos Direitos Fundamentais. Trad. Virgílio Afonso da Silva. São Paulo: Malheiros, 2008, p. 574.

${ }^{215}$ FARBER, Daniel; e SHERRY, Suzanna. Judgment Calls: principles and politics in Constitutional Law. Oxford: Oxford University Press, 2009, pp. 24-25.

${ }^{216}$ FARBER, Daniel; SHERRY, Suzanna. Judgment Calls: principles and politics in Constitutional Law. Oxford: Oxford University Press, 2009, p. 25.

${ }^{217}$ Cf. BALLWEG, Ottmar. Retórica analítica e direito. Trad. João Maurício Adeodato. Mimeo. No original em alemão: Rhetorik und Vertrauen In: Kritik und Vertrauen: Festschift für Peter Schneider zum 70 Geburtstag. Frankfurt a.M.: Anton Hain Verlag, 1990, pp. 34-44.
} 
viva visa à balança interna da cultura em que a justiça é experimentada. Sendo assim, a justiça não se traduz na opinião majoritária ou no conformismo social e o sentimento de justiça da maioria pode ser influenciado pela retórica jurídica. ${ }^{218}$

Nesse quadro democrático, uma Corte Constitucional tem o papel de fechar a cadeia argumentativa acerca de tópicos oriundos da tentativa de aprimoramento da vivência compartilhada em sociedade. Assim, à luz do ceticismo ético que informa a matriz teórica retórica, o controle constitucional de normas tem sua espacialidade legitimada pela autoridade da instituição, e não propriamente por uma racionalidade substancialmente diferenciada a qual produz resultados mais justos.

Por conseguinte, a funcionalidade do discurso judicial decorre, em certa medida, da constrição da decisão (non liquet), porquanto deve filtrar do caos cotidiano uma ordem jurídica, por intermédio de procedimentos legais e da linguagem, de maneira a tornar um conjunto infinito em um sistema finito. ${ }^{219}$

Sendo assim, o fundamento do discurso da jurisdição constitucional em uma democracia é sempre um momento de força, que procura se justificar, à luz de uma fundamentabilidade discursiva, conforme defende Tércio Sampaio Ferraz Jr. É dizer: há a possibilidade de que a imposição normativa seja justificável e defensável quando criticada, tendo em conta uma cosmovisão ideológica. Em síntese, a legitimidade do discurso normativo "não se funda na força, porque é sempre uso justificado ideologicamente da força que passa, então, a fazer parte dele, ao nível do relato, sob forma de sanção."220

\subsubsection{A possibilidade e a conveniência da jurisdição constitucional na democracia}

Em tentativa de sistematização, é viável afirmar a condição de possibilidade e conveniência política de uma corte constitucional, com parâmetro em um paradigma democrático fundado na noção de soberania popular, tendo em vista as potencialidades explicativas da tópica moderna inaugurada por Theodor Viehweg e desenvolvida pelas teorias da argumentação jurídica.

\footnotetext{
218 SOBOTA, Katharina. The Rhetorical Construction of Law. In: International Journal for the Semiotics of Law, v. 13, 1992, pp. 39-54, p. 54.

219 FARBER, Daniel; SHERRY, Suzanna. Judgment Calls: principles and politics in Constitutional Law. Oxford: Oxford University Press, 2009, pp. 42-43.

${ }^{220}$ FERRAZ JUNIOR, Tércio Sampaio. Teoria da Norma Jurídica. 2 ed. Rio de Janeiro: Forense, 1986, p. 177.
} 
Assim, é possível um arranjo institucional que permita a produção de discursos racionais e adequados, em sede de jurisdição constitucional, às exigências democráticas, caso se tome como referência os arcabouços teóricos extraídos das perspectivas teóricas da teoria da argumentação jurídica padrão e da retórica moderna.

As teorias da argumentação jurídica standard possuem como pressuposto a fundamentação de juízos éticos do ponto de vista cognoscitivo, à luz de um objetivismo moral mínimo. Por conseguinte, o modelo de racionalidade proposta a partir da tese do caso especial permite pensar em uma avaliação substancial da racionalidade das decisões do Poder Judiciário, inclusive com exigências de "regras universais".

Por outro lado, a retórica moderna adota uma postura cética, em decorrência da multiplicidade de visões de mundo, o que não permitiria a universalização de juízos éticos. Nos estritos limites da pretensão analítica dessa corrente de pensamento, a racionalidade simplesmente não é uma questão, uma vez que o racional se define retoricamente, consoante à situação comunicativa posta. À luz do necessário relacionamento entre democracia e retórica, aponta-se a possibilidade de uma corte constitucional que interrompa a cadeia argumentativa com sua decisão, o que funcionaliza a própria democracia. Ou seja, a jurisdição constitucional se presta a um controle de normas oriundo de sua própria autoridade.

De qualquer forma, ambas as vertentes teóricas possuem a potencialidade, ainda que em diferente níveis, de contribuir ao debate acerca da adequação democrática do controle de constitucionalidade, sobretudo em relação à tutela de direitos fundamentais e aos impasses institucionais entre os Poderes.

\subsection{Estratégias Metodológicas de Análise de Discursos do STF a partir da Teoria da Argumentação Jurídica Padrão e da Retórica Moderna}

Neste momento, torna-se imperativo abordar, com alguma objetividade, as estratégias metodológicas de análise dos discursos judiciais. Como posto na seção anterior, o exame se dará com viés comparativo, à luz dos pressupostos e fins das duas matrizes teóricas referentes às hodiernas teorias da argumentação jurídica, quais sejam, a moderna retórica e a argumentação jurídica standard.

$\mathrm{Na}$ qualidade de técnica conectiva entre os procedimentos e a vertente metodológica 
da pesquisa, a estratégia adotada é a análise de conteúdo, operacionalizada pelo exame conjectural e de conteúdo do julgado supracitado. De acordo com Miracy Gustin e Maria Tereza Dias, essa técnica tem condições de produção próprias, porquanto os dados e informações apresentam-se dissociados do contexto originário, isto é, "desmonta-se o(s) discursos(s) da realidade objeto da pesquisa e se produz um novo discurso por meio de "traços de significação', que resultam da relação dialética entre as condições de produção do discurso objeto de análise e as condições de produção da análise"221.

Ademais, a análise de discurso como abordagem de estudo de textos se insere na tradição científica como crítica ao modo tradicional de se fazer ciências sociais, uma vez que a base epistemológica daquela é o construtivismo social, caracterizável pelos seguintes aspectos: (i) uma posição crítica aos dogmas cognitivos, assim como postura cética em relação a uma visão naturalizada do mundo; (ii) o reconhecimento de que o que conhecemos como mundo é construído historicamente e culturalmente em termos específicos e relativos; (iii) a convicção de que o conhecimento é construído socialmente; e (iv) o compromisso de explorar as formas que o conhecimento se interliga com ações e práticas. ${ }^{222}$

Em relação à retórica moderna, inspira-se na formulação de Isaac Reis tachada de Análise Empírico-Retórica do Discurso (AERD), para os fins de sua tese de doutoramento. ${ }^{223}$ Por outro lado, no bojo da teoria da argumentação jurídica padrão, utiliza-se como referencial o modelo de análise de decisões judiciais desenvolvido por Basile Christopoulos, também funcionalizada para sua pesquisa de doutorado ${ }^{224}$, com fulcro na linha de pensamento do jurista escocês Neil MacCormick, notadamente em sua visão retórica ${ }^{225} /$ dialética $^{226}$ do

\footnotetext{
${ }^{221}$ GUSTIN, Miracy Barbosa de Sousa; DIAS Maria Tereza Fonseca. (Re)pensando a Pesquisa Jurídica: teoria e prática. Belo Horizonte: Del Rey, 2002, p. 111.

${ }^{222}$ GILL, Rosalind. Discourse Analysis. In: BAUER, Martin W.; GASKELL, George. Qualitative Researching with Text, Image and Sound: a practical handbook. Londres: Sage, 2000.

223 REIS, Isaac Costa. Limites à legitimidade da jurisdição constitucional: análise retórica das cortes constitucionais do Brasil e da Alemanha. 265 f. Tese de Doutorado - Faculdade de Direito, Universidade Federal de Pernambuco, Recife-PE, Brasil, 2013.

224 CHRISTOPOULOS, Basile Georges Campos. Controle de Constitucionalidade de Normas Orçamentárias: o uso de argumentos consequencialistas nas decisões do Supremo Tribunal Federal. $240 \mathrm{f}$. Tese de Doutorado Faculdade de Direito, Universidade de São Paulo, São Paulo-SP, Brasil, 2014.

${ }^{225}$ Compartilha-se da crítica realizada por Manuel Atienza, em entrevista realizada com Neil MacCormick e publicada na Revista Doxa, em relação à aproximação do pensamento do jurista escocês, em suas últimas obras acerca da argumentação jurídica, à vertente dialética ou dialógica do ramo da filosofia interessada na argumentação em um âmbito geral, a qual, segundo o filósofo do Direito espanhol, pode ser sumarizada nas dimensões retórica, dialética e lógica: "M.A.: En estos días estoy leyendo tu libro Rhetoric and the Rule of Law (...) Estoy muy de acuerdo con los aspectos sustantivos de tu nuevo libro, pero no encuentro totalmente persuasivo el uso que propones de 'retórica' (...) En mi opinión, el riesgo de tu propuesta reside en perder algunas diferencias interesantes (por ejemplo, entre la aproximación a la argumentación de TOULMIN y de PERELMAN) y también en subestimar los aspectos dialógicos o dialécticos ('dialéctica' y 'diálogo' no están incluidos en el Índice de Materias de tu libro).” (ATIENZA, Manuel. Entrevista a Neil MacCormick. In: Doxa:
} 
Direito, a qual pressupõe um consequencialismo "brando". 227

Nesse sentido, o expediente argumentativo desta subseção consiste primeiramente na descrição de ambas as contribuições metodológicas supracitadas. Contudo, os problemas e objetivos da presente pesquisa exigem adaptações, supressivas e aditivas, sobretudo pelo caráter qualitativo e singularizado do que se propõe, isto é, a descrição retórica e a avaliação da consistência argumentativa da ADI-MC 4.048. Logo, seguidamente, será explicitada a utilidade desses marcos referencias, em termos funcionais, para a perquirição analítica aqui proposta.

Na pesquisa de Christopoulos, utilizou-se como estratégia de delimitação temática certa tipologia de argumentos centrais das decisões analisadas proferidas pelo STF em âmbito de controle abstrato de constitucionalidade sob a vigência da $\mathrm{CR} / 88$ em relação à temática de leis e normas orçamentárias. Nesses termos, estabelece-se como feixes tipológicos os argumentos deontológicos, os consequencialistas jurídicos e os consequencialistas econômicos e extrajurídicos. A partir disso, pode-se analisar a centralidade de cada tipo de argumento para a formação de precedentes, principalmente ao reconhecer aqueles como ratio decidendi ou obiter dictum.

Assim sendo, cada acórdão foi examinado sob cinco aspectos: o contexto da decisão e os dispositivos atacados; argumentos deontológicos; argumentos consequencialistas jurídicos; argumentos consequencialistas extrajurídicos; e análise de composição de argumentos. Em termos de argumentos, buscou-se concebê-los pela classificação dantes mencionada. Por outro

\footnotetext{
cuadernos de filosofia del Derecho, Alicante-ES, n. 29, 2006, pp. 479-489, p. 487)

${ }^{226}$ Já no pensamento de Aristóteles, observa-se a correlação entre a retórica e a dialética: "A retórica é a outra face da dialéctica; pois ambas se ocupam de questões mais ou menos ligadas ao conhecimento comum e não correspondem a nenhuma ciência em particular. De facto, todas as pessoas de alguma maneira participam de um ou de outra, pois todas elas tentam em certa medida questionar e sustentar um argumento, defender-se ou acusar" (ARISTÓTELES. Retórica. 2 ed. Trad. Manuel Alexandre Júnior, Paulo Farmhouse Alberto e Abel do Nascimento Pena. Lisboa: Imprensa Nacional-Casa da Moeda, 2005, p. 89). Trata-se, portanto, de uma visão substancialmente distinta da exposta até então pela filosofia grega a respeito da retórica, como se percebe especialmente no diálogo platônico "Fedro" acerca do Amor. Isso porque a matriz aristotélica reconhece uma utilidade persuasiva da retórica em relação ao justo, belo e bom.

${ }^{227}$ Para MacCormick, argumentos consequencialistas são aqueles que levam em conta consequências jurídicas, traduzíveis em implicações lógicas da decisão no ordenamento jurídico: "O nome é bem escolhido pois, para declarar um direito em particular (jus dicere) é necessário, no papel de juiz imparcial, declarar que tal direito está disponível em todos os casos semelhantes. Assim, como uma pessoa prudente e cautelosa, qualquer juiz deve olhar, dentre o conjunto de situações possíveos, qual terá que ser coberta, do ponto de vista jurídico pela sentença proposta. Tal consideração do conjunto de casos possíveis é necessária para uma avaliação adequada da aceitabilidade da decisão tomada no caso presente (...) Assim, em essência, o que eu chamo de Direito da argumentação consequencialista é focado não tanto em estimar a probabilidade de mudanças comportamentais, mas na conduta possível e em seu determinado status normativo à luz da decisao que está sendo considerada." (MACCORMICK, Neil. Retórica e o Estado de Direito. Trad. Conrado Hübner Mendes. Rio de Janeiro: Elsevier, 2008, pp. 142 e 147)
} 
lado, a composição dos arrazoados serviu "para fazer um balanço dos argumentos utilizados no acórdão, bem como um diagnóstico final sobre a relevância dos argumentos consequencialistas em cada decisão."228

Exposta a estratégia metodológica, ressalta-se que se aproveita, na presente perquirição, a mesma divisão de argumentos em ratio decidendi e obiter dictum $^{229}$. Nesses termos, a razão de decidir se funcionaliza na justificativa ${ }^{230}$ da decisão judicial em um sistema de precedentes ${ }^{231}$ como reconstrução racional da doutrina e das práticas jurídicas efetivas. Isso porque, em suma, argumentar a partir de precedentes significa manter a mesma ratio decidendi para casos análogos, consoante ao defendido por MacCormick, tendo em vista que "sob um sistema de precedentes vinculantes ou persuasivos, tais decisões também transcendem cada caso particular e são recebidas como criadoras do Direito ou como decisões que interpretam e determinam o Direito com autoridade" 232 .

Por outro lado, o contexto da decisão e os dispositivos atacados são também relevantes para o presente estudo, todavia há uma alteração topográfica ao proposto por Christopoulos para o início da exposição e de forma centralizada, em decorrência da escolha em verticalizar o exame da ADI-MC 4.048, de modo que se almeja dar maior facilidade explanatória à dinâmica conjectural pertinente.

\footnotetext{
${ }^{228}$ CHRISTOPOULOS, Basile Georges Campos. Controle de Constitucionalidade de Normas Orçamentárias: o uso de argumentos consequencialistas nas decisões do Supremo Tribunal Federal. $240 \mathrm{f}$. Tese de Doutorado Faculdade de Direito, Universidade de São Paulo, São Paulo-SP, Brasil, 2014, p. 151.

229 "Dentro de tal modelo, pode-se dar uma definição clara e satisfatória de ratio decidendi, nos seguintes termos: Uma ratio decidendi é uma justificação formal explícita ou implicitamente formulada por um juiz, e suficiente para decidir uma questão jurídica suscitada pelos argumentos das partes, questão sobre a qual uma resolução era necessária para a justificação da decisão no caso [...]. É necessário notar que a ratio, nessa visão, é uma função da decisão e da justificativa oferecidas por um juiz para tal decisão. Desse modo, podem existir múltiplas rationes. Um juiz pode achar necessário formular uma solução em mais de um ponto em questão." (MACCORMICK, Neil. Retórica e o Estado de Direito. Trad. Conrado Hübner Mendes. Rio de Janeiro: Elsevier, 2008, p. 203).

230 "Justificar um ato é mostrar que ele é correto. Mostrar que ele é correto é mostrar que, sob qualquer visão objetiva da matéria, o ato deveria ter sido praticado, ou mesmo deve ser praticado, considerando as características do ato e as circunstâncias do caso.” (MACCORMICK, Neil. Retórica e o Estado de Direito. Trad. Conrado Hübner Mendes. Rio de Janeiro: Elsevier, 2008, p. 129)

231 "Precedente não se confunde com decisão ou com justificativa. A decisão é a resolução de um caso, cuja justificativa pode ou não dar origem a uma ratio decidendi e, por conseguinte, a um precedente. Note-se que a justificativa, mesmo quando contém a ratio, também trata de vários outros aspectos do caso.

Não há dúvida de que não há precedente sem ratio decidendi, mas o precedente é mais do que a ratio. É certo que a parte do precedente que importa, enquanto regra que regulará os casos futuros, é a ratio decidendi. Porém o precedente, se necessariamente contém a ratio, também abarca outros pontos. O precedente descreve o contexto fático e os fundamentos objeto da discussão, possui a proclamação do resultado, além de conter a justificativa dos fundamentos concorrentes e dissidente e de abordar, conscientemente ou não, questões decididas obiter dicta." (MARINONI, Luiz Guilherme. Julgamento nas Cortes Supremas: precedente e decisão do recurso diante do novo CPC. São Paulo: Revista dos Tribunais, 2015, p. 139).

${ }^{232}$ MACCORMICK, Neil. Retórica e o Estado de Direito. Trad. Conrado Hübner Mendes. Rio de Janeiro: Elsevier, 2008, p. 339.
} 
De qualquer modo, reputa-se a mais sensível diferença entre as estratégias propostas o tratamento que se dá aos argumentos consequencialistas, em razão dos influxos dialógicos que a presente pesquisa pretende ter com a retórica moderna. Logo, não se aceita a divisão entre jurídico e extrajurídico desse tipo de argumento, visto que essa tipologia pressupõe a prescrição de inadequação racional no Direito do raciocínio chamado de extrajurídico. ${ }^{233}$ Aceitá-la, portanto, reduziria o espaço comparativo entre as matrizes teóricas hauridas das teorias da argumentação jurídica, a partir de um conceito estreito de racionalidade jurídica, o que não interessa para esta pesquisa.

A despeito do recente interesse doutrinário em âmbito brasiliano acerca dos fatores “extrajurídicos" influenciadores da prestação jurisdicional ${ }^{234}$, adota-se uma postura fugidia a rótulos dessa espécie, porquanto se enxerga a suposta extrajuridicidade apenas como expressão das constrições ou condicionantes da auto-referência ${ }^{235}$ e do decoro ${ }^{236}$ aplicáveis ao discurso jurídico, à luz da construção retórica do Direito como proposta por Katharina Sobota. $^{237}$

Em síntese, pertencem ao universo do jurídico: a pseudo auto-referência, na qualidade de etiologia jurídica, isto é, descrição retórica da gênese da decisão judicial, geralmente encarados como argumentos "jurídicos", consequencialistas ou não; e a cripto auto-referência, traduzível na comunicação jurídica não-oficial, formada pelos rituais forenses, técnicas retóricas, experiência e seleção de juristas, entre outros fatores, dimensão discursiva tida por "extrajurídica" ${ }^{238}$. Então, não se sustentaria uma divisão entre argumentos consequencialistas jurídicos e extrajurídicos, consideradas as premissas teórico-metodológicas convencionadas

\footnotetext{
233 "Há, implicitamente ou não, uma prescrição de que tipo de argumento consequencialista é possível ou adequado racionalmente no direito, a partir da conclusão de que os argumentos do terceiro tipo não seriam adequados. Isto é, argumentos classificados como extrajurídicos em tese seriam desaconselhados para uma boa decisão, ou uma decisão convincente." (CHRISTOPOULOS, Basile Georges Campos. Controle de Constitucionalidade de Normas Orçamentárias: o uso de argumentos consequencialistas nas decisões do Supremo Tribunal Federal. 240 f. Tese de Doutorado - Faculdade de Direito, Universidade de São Paulo, São Paulo-SP, Brasil, 2014, p. 150)

${ }^{234}$ Vide: FERNANDES, Ricardo Vieira de Carvalho. Influências Extrajurídicas sobre a Decisão Judicial: determinação, previsibilidade e objetividade do direito brasileiro. $352 \mathrm{f}$. Tese de Doutorado - Faculdade de Direito, Universidade de Brasília, Brasília-DF, Brasil, 2013.

${ }^{235}$ Condicionante que permite a compressão da viabilidade do sistema jurídico se estabilizar e manter sua existência, ao fundamento de uma pressuposução artificial baseada em um segundo nível de observação, a qual, ao fim e ao cabo, permite a representação das interações sociais de maneira prescritiva.

${ }^{236} \mathrm{O}$ Discurso judicial deve ser produzido de uma maneira vista como decorosa/apropriada pela audiência, de modo que o emprego do lugar-comum é delimitado pela situação comunicativa.

${ }^{237}$ Cf. SOBOTA, Katharina. The Rhetorical Construction of Law. In: International Journal for the Semiotics of Law, v. 13, 1992, pp. 39-54.

${ }^{238}$ SOBOTA, Katharina. The Rhetorical Construction of Law. In: International Journal for the Semiotics of Law, v. 13, 1992, pp. 39-54.
} 
no presente trabalho.

Igualmente, por não compor a plêiade de problemas, hipóteses e objetivos da presente perquirição acadêmica, também será excluído do referencial analítico o diagnóstico derradeiro sobre a relevância dos argumentos consequencialistas em cada decisão.

No tocante à Análise Empírico-Retórica do Discurso (AERD) proposta por Isaac Reis, tem-se que a assunção de uma série de pressupostos da retórica moderna, portanto se concebe o discurso jurídico como autorreferente, artefatual, dinâmico e conflituoso.

Em termos qualitativos, essa estratégia busca analisar discursos por meio de textos, entendidos como porta de entrada para o discurso, na medida em que texto e discurso se diferenciam, a empresa do analista se traduz em perceber como o discurso se textualiza. À luz da moderna retórica, não é possível ter pretensões de objetividade, tampouco neutralidade técnica do analista. ${ }^{239}$ Outra limitação da AERD é a falta de representatividade, dado que não se pretende quantitativa.

Considerado o exame discursivo como instrumental de tratamento de falas e textos organizados retoricamente, a ênfase na natureza retórica dos textos dirige a atenção do analista para a forma como todos os discursos se organizam para fins de se tornarem persuasivos. $^{240}$ Aliás, na arte retórica de Aristóteles, entende-se "por retórica como a capacidade de descobrir o que é adequado a cada caso com o fim de persuadir. Esta não é seguramente a função de nenhuma outra arte". ${ }^{241}$

Ademais, o critério de validade de uma análise é pragmático, depende, então, do reconhecimento e apreciação como tal em uma comunidade de analistas, sobretudo em comparação com outras análises de mesma índole. Depende, igualmente, da coerência da análise, ao levar em conta o estado da arte promovida pelas pesquisas anteriores, assim como da publicização dos resultantes analíticos, sob o crivo da crítica pública ${ }^{242}$, afinal se considera que "o discurso, uma vez lançado no mundo dos eventos, descola-se do seu emissor,

\footnotetext{
239 REIS, Isaac Costa. Limites à legitimidade da jurisdição constitucional: análise retórica das cortes constitucionais do Brasil e da Alemanha. 265 f. Tese de Doutorado - Faculdade de Direito, Universidade Federal de Pernambuco, Recife-PE, Brasil, 2013, p. 70.

${ }^{240}$ GILL, Rosalind. Discourse Analysis. In: BAUER, Martin W.; GASKELL, George. Qualitative Researching with Text, Image and Sound: a practical handbook. Londres: Sage, 2000, p. 173.

${ }^{241}$ ARISTÓTELES. Retórica. 2 ed. Trad. Manuel Alexandre Júnior, Paulo Farmhouse Alberto e Abel do Nascimento Pena. Lisboa: Imprensa Nacional-Casa da Moeda, 2005, pp. 95-96.

242 REIS, Isaac Costa. Limites à legitimidade da jurisdição constitucional: análise retórica das cortes constitucionais do Brasil e da Alemanha. 265 f. Tese de Doutorado - Faculdade de Direito, Universidade Federal de Pernambuco, Recife-PE, Brasil, 2013, p. 70.
} 


\section{ingressando no mercado público do sentido"243.}

Do ponto de vista adaptativo da estratégia metodológica, como processo de caráter coletivo e cooperativo, a própria AERD é concebida como instrumento com produção adrede, ou seja, desenvolvido "senão diante de hipóteses de trabalho produzidas em cada análise, buscando focar elementos específicos. Do contrário, incorreria nos mesmos delírios de totalidade e prepotência gnoseológica que são a marca dos métodos de corte essencialista."244

Por conseguinte, adotam-se também as dimensões discursiva de tradição aristotélica distribuídas em ethos (E), pathos (P) e logos (L). Para Aristóteles, "As provas de persuasão fornecidas pelo discurso são de três espécies: umas residem no carácter moral do orador; outras, no modo como se dispõe o ouvinte; e outras, no próprio discurso, pelo que este demonstra ou parece demonstrar" 245 .

A dimensão E se refere ao caráter moral do orador, quando o discurso é persuasivo em decorrência do orador ser digno de fé. A dimensão P se caracteriza pela disposição dos ouvintes na medida em que seus juízos são afetados pela capacidade do discurso em produzir emoção (paixões). A dimensão L se notabiliza pela persuasão pelo discurso, ao deixar se mostrar a verdade ou o que aparenta sê-la, em cada caso particular, sobretudo por meio de entinemas e exemplos. Portanto, as dimensões propostas pelo Estagirita, e aqui incorporadas, diferenciam-se a partir da ênfase que se dá ao orador, ouvinte ou discurso. ${ }^{246}$

Como visto, a construção de indicadores revela-se um exercício individualizado a cada análise e propósito de pesquisa para a AERD. Nesse ponto, pretende-se simplificar a análise proposta por Reis, a partir da diminuição do número de indicadores em cada dimensão discursiva. Ocorre que nos julgados examinados pelo jurista buscava-se captar uma riqueza de sentidos linguísticos, apreensíveis e possíveis graças aos dilemas morais próprios da bioética e dos direitos da personalidade (células-tronco embrionárias e casos de interrupção da gravidez). Essa intenção não se apresenta na presente pesquisa, porquanto a temática orçamentária é marcada por pretensa tecnicidade, desde o jargão à postura dos falantes e

\footnotetext{
243 REIS, Isaac Costa. Limites à legitimidade da jurisdição constitucional: análise retórica das cortes constitucionais do Brasil e da Alemanha. 265 f. Tese de Doutorado - Faculdade de Direito, Universidade Federal de Pernambuco, Recife-PE, Brasil, 2013, p. 67, grifos no original.

244 REIS, Isaac Costa. Limites à legitimidade da jurisdição constitucional: análise retórica das cortes constitucionais do Brasil e da Alemanha. 265 f. Tese de Doutorado - Faculdade de Direito, Universidade Federal de Pernambuco, Recife-PE, Brasil, 2013, p. 66.

${ }^{245}$ ARISTÓTELES. Retórica. 2 ed. Trad. Manuel Alexandre Júnior, Paulo Farmhouse Alberto e Abel do Nascimento Pena. Lisboa: Imprensa Nacional-Casa da Moeda, 2005, p. 96.

${ }^{246}$ ARISTÓTELES. Retórica. 2 ed. Trad. Manuel Alexandre Júnior, Paulo Farmhouse Alberto e Abel do Nascimento Pena. Lisboa: Imprensa Nacional-Casa da Moeda, 2005, pp. 96-97.
} 
ouvintes, o que, de alguma forma, inibe as manifestações expressivas constantes do objeto de estudo da precitada tese de doutorado.

Diante do exposto, são propostos os seguintes indicadores nas dimensões E, P e L:

E1: Demonstração de conhecimento ou erudição. Tem-se o efeito de associar competência gnoseológica a legitimidade política;

E2: Amplificação do valor da Constituição ou do caso em exame. Promoção de conexão entre responsabilidade e poder;

E3: Elogios. Adjetivações elogiosas aos demais membros da Corte e participantes da relação processual, objetivando-se o enaltecimento das qualidades do Tribunal e de si mesmo, como par;

E4: Relacionamento entre os Poderes. Esse indicador abarca da supremacia judicial à deferência institucional, passando pelo aconselhamento aos demais poderes. Argumenta-se, então, em favor da credibilidade e legitimidade da própria Corte no quadro estatal, a partir da defesa do campo jurídico-constitucional da interferência de outros atores políticos, alertas contra os perigos de uma realidade em que o legislador tenha a primazia interpretativa sob a $\mathrm{CR} / 88$, entre outros expedientes.

P1: Linguagem hiperbólica e argumento ad terrorem. Trata-se da utilização de "linguagem perceptivelmente hiperbólica ou da utilização de argumentos que consistem em justificar a adoção de uma posição pelo incutimento de temor pelas consequências que poderão advir, caso vença a opinião contrária"247;

P2: Ênfase e pergunta retórica. Representações tipográficas, como, por exemplo, o negrito, itálico ou pontos de exclamação; e perguntas com respostas anteriormente conhecidas, para fins persuasivos;

P3: Remissão à opinião pública ou publicada. Tentativa de provocar sentimentos de empatia, identidade e pertencimento em atores alheios ao processo decisório, os quais compõe o auditório das manifestações expendidas no curso do julgamento; e

P4: Apartes divergentes. Intervenções ou perguntas realizadas no decorrer da manifestação de voto de colegas, sem intuito dialógico, com o fito de reafirmar a divergência

\footnotetext{
247 REIS, Isaac Costa. Limites à legitimidade da jurisdição constitucional: análise retórica das cortes constitucionais do Brasil e da Alemanha. 265 f. Tese de Doutorado - Faculdade de Direito, Universidade Federal de Pernambuco, Recife-PE, Brasil, 2013, p. 157.
} 
de pensamento e marcar posição, inclusive sem o compartilhamento de premissas.

L1: Argumentos baseados nas fontes ${ }^{248}$ do Direito. Referências aos diplomas legislativos, jurisprudência, Constituição da República, princípios gerais, demais elementos textuais ou não reconhecidos como vinculantes e dotados de juridicidade pela comunidade de intérpretes do Direito.

L2: Argumentos hermenêuticos. Explicitação dos mecanismos interpretativos de acesso ao significado dos textos jurídicos.

L3: Argumentos do cotidiano. Referências à experiência prática e ao senso comum.

L4: Operações de lógica. Utilização de deduções, inferências, induções e outros métodos de investigação lógica.

Ademais, verifique-se a sistematização das dimensões e dos indicadores propostos para a presente AERD em forma de quadro:

Quadro 1 - Dimensões e indicadores da AERD

\begin{tabular}{|l|l|}
\hline \multirow{2}{*}{ DIMENSÃO } & \multicolumn{1}{c|}{ INDICADOR } \\
\hline \multirow{2}{*}{ ETHOS } & E1: Demonstração de conhecimento ou erudição. \\
\cline { 2 - 3 } & E2: Amplificação do valor da Constituição ou do caso em exame. \\
\cline { 2 - 3 } & E3: Elogios. \\
\cline { 2 - 3 } & E4: Relacionamento entre os Poderes. \\
\hline \multirow{2}{*}{ PATHOS } & P1: Linguagem hiperbólica e argumento ad terrorem. \\
\cline { 2 - 3 } & P2: Ênfase e pergunta retórica. \\
\hline
\end{tabular}

${ }^{248}$ Em tempos de multiplicidade de esferas dotadas de juridicidade, esta pesquisa recorre às noções introdutórias do Direito, tal como ensinadas nos cursos de bacharelado em Direito, em que pese as inúmeras críticas constantes na literatura especializada e a clara inspiração oitocentista do artefato conceitual. Logo, "Fonte jurídica seria a origem primária do direito, confundindo-se com o problema da gênese do direito. Trata-se da fonte real ou material do direito, ou seja, dos fatores reais que condicionaram o aparecimento de normas jurídica (...) Emprega-se também o termo 'fonte do direito' como equivalente ao fundamento de validade da ordem jurídica." (DINIZ, Maria Helena. Compêndio de Introdução à Ciência do Direito. 5 ed. São Paulo: Saraiva, 1993, p. 250) 


\begin{tabular}{|l|l|}
\hline \multirow{2}{*}{ LOGOS } & P3: Remissão à opinião pública ou publicada. \\
\cline { 2 - 3 } & P4: Apartes divergentes. \\
\hline L1: Argumentos baseados nas fontes do Direito. \\
\cline { 2 - 3 } & L2: Argumentos hermenêuticos. \\
\cline { 2 - 3 } & L3: Argumentos do cotidiano. \\
\cline { 2 - 2 } & L4: Operações de lógica. \\
\hline
\end{tabular}

Fonte: Elaboração própria, com referencial em REIS, 2013, p. 158.

Com auxílio dessa elaboração conceitual, pretende-se traçar os perfis retóricos da decisão colegiada e respectivos votos vogais de cada participante do processo decisório, com base na frequência, expressividade e relevância de cada um dos indicadores previamente estabelecidos ao longo do inteiro teor do acórdão da ADI-MC 4.048.

Ao fim e ao cabo, no plano da pseudo auto-referência, intenta-se descrever retoricamente a gênese da decisão, por meio de figuras retóricas (apelações ao "coração" aspecto sentimental) e pseudo-referências acerca do bom e do justo (apelações ao "cérebro" aspecto pensante). ${ }^{249}$

\subsection{A Medida Cautelar na Ação Direta de Inconstitucionalidade 4.048}

Principia-se a presente subseção com a exposição dos entendimentos prévios do STF, sob a vigência da $\mathrm{CR} / 88$, acerca da possibilidade de controle de constitucionalidade de cunho abstrato referenciado a leis orçamentárias. Nesse sentido, reconstrói-se a interpretação do permissivo constitucional encartado no art. 102, I, "a", da CR/ $88^{250}$, desde a necessidade de abstração e generalidade das leis impugnadas em fiscalização abstrata em direção à abertura

\footnotetext{
${ }^{249}$ SOBOTA, Katharina. The Rhetorical Construction of Law. In: International Journal for the Semiotics of Law, v. 13, 1992, pp. 39-54, pp. 46-50.

${ }^{250}$ Art. 102. Compete ao Supremo Tribunal Federal, precipuamente, a guarda da Constituição, cabendo-lhe: I processar e julgar, originariamente: a) a ação direta de inconstitucionalidade de lei ou ato normativo federal ou estadual e a ação declaratória de constitucionalidade de lei ou ato normativo federal.
} 
da via objetiva a toda lei federal ou estadual, independente do caráter geral ou específico, concreto ou abstrato do objeto da ADI.

Depois, pretende-se abordar panoramicamente o julgamento, com a exposição do contexto do feito e os dispositivos atacados, de maneira a não perder a perspectiva de deliberação colegiada em face dos votos condutores das correntes vencedora e vencida.

Ademais, sob as lentes do traçado metodológico anteriormente exposto, notadamente com base na teoria da argumentação jurídica de Neil MacCormick e na moderna retórica formulada pela Escola de Mainz, dar-se-á a verticalização analítica dos discursos produzidos na oportunidade da decisão.

Em relação à matriz das teorias da argumentação jurídica standard, a partir da categoria jurídica de precedente, pretende-se sindicar em que medida a ADI-MC 4.048 representou uma superação do entendimento pretérito. Além disso, será examinado o julgado, à luz dos parâmetros da consistência, coerência e consequencialismo constantes na concepção de MacCormick do Direito como ordem normativa institucional.

Noutra banda, forte na construção retórica do Direito, pretende-se apontar e examinar os elementos discursivos do feito nas dimensões do ethos, pathos e logos, a partir dos indicadores precitados e com atenção na representação de um catálogo provisório das condições fundamentais para responder as questões de quando e em que circunstâncias a rede discursiva do Direito se desenvolve persuasivamente, especialmente em matéria constitucional-financeira e na espacialidade do STF.

\subsubsection{A narrativa jurisprudencial acerca do controle objetivo de normas orçamentárias}

De plano, justifica-se o presente subtítulo pela dimensão auxiliar da narrativa em relação à argumentação, isto é, a narração possui um conteúdo precipuamente informativo, pois se funcionaliza no esclarecimento da situação fático-normativa da qual vai se desenvolver a argumentação, ou seja, "antes de argumentar, de procurar apresentar uma tese que convença o interlocutor, é necessário fixar premissas amplamente aceitáveis, que sirvam 
como base de percurso argumentativo." ${ }^{251}$ Contudo, também há uma dimensão persuasiva, implícita ou não, no âmbito da narrativa, uma vez que reflete a visão do autor sobre a realidade construída. ${ }^{252}$

Por evidente, ambas as dimensões se fazem presentes tanto na presente pesquisa, quanto na compreensão que o STF possui de si como órgão judicante, a partir da reconstrução racional de seus precedentes. Nesse sentido, como não se busca um discurso meta-teórico, aqui o enfoque residirá na formulação de decisões judiciais em sede de controle objetivo de constitucionalidade com referência às leis orçamentárias. É dizer: preocupa-se, ao menos discursivamente, com a etiologia dos precedentes pertinentes à temática, vistos como tais na doutrina e na práxis judicial.

Ademais, na esteira do pensamento de Chaim Perelman e Lucie Olbrechts-Tyteca, a própria seleção e presença de dados serve como ponto de partida à argumentação jurídica, uma vez que a anterioridade e a seletividade se funcionalizam em adaptação aos objetivos argumentativos do emissor da mensagem. Nesse sentido, "toda argumentação supõe, portanto, uma escolha, que consiste não só na seleção dos elementos que são utilizados, mas também na técnica da apresentação deles."253

Outra premissa adotada e digna de explicitação é o aspecto prospectivo dos precedentes, o que contraria a divisão entre discurso judicial e o deliberativo presente em Aristóteles, depois incorporada em uma noção positivista de precedente. Nas palavras de Frederick Schauer, a visão tradicional de precedente, dentro e fora do Direito, enfoca na ideia de que o precedente de ontem é a decisão de hoje. No entanto, uma noção de legitimidade meramente autoritativa dos precedentes encontra pouca sustentabilidade diante do fenômeno da criação judicial do Direito. Por conseguinte, o aspecto prospectivo do precedente significa dizer que a decisão de hoje deve se transformar no precedente das instâncias decisórias amanhã. Logo, um sistema de precedentes envolve uma responsabilidade especial que se

\footnotetext{
${ }^{251}$ RODRÍGUEZ, Víctor Gabriel. Argumentação Jurídica: técnicas de persuasão e lógica informal. São Paulo: Martins Fontes, 2005, p. 89.

252 "A narrativa representa ao argumentante, no discurso judiciário, uma premissa e uma grande oportunidade. Premissa porque, como vimos, é dos fatos que surgem os direcionamentos da argumentação, e as informações necessários para que o interlocutor a compreenda e, logo, a aceite; e grande oportunidade porque, ainda que não admita uma atividade suasória expressa, tem a narrativa, diluído em seu conteúdo, grande poder de persuasão, ao informar o interlocutor para que ele aceite uma versão dos fatos verdadeira e verossímil, que contribua para a conclusão a ser apresentada no momento argumentativo próprio" (RODRÍGUEZ, Víctor Gabriel. Argumentação Jurídica: técnicas de persuasão e lógica informal. São Paulo: Martins Fontes, 2005, p. 106)

${ }^{253}$ PERELMAN, Chaim; OLBRECHTS-TYTECA, Lucie. Tratado da Argumentação: a nova retórica. Trad. Maria Ermantina de Almeida Prado Galvão. São Paulo: Martins Fontes, 2005, p. 136.
} 
traduz em comprometer o futuro aprioristicamente. ${ }^{254}$

Nesse sentido, a revisão de jurisprudência (overrruling) operada no objeto de estudo dessa pesquisa deve ser levada a sério, caso se tenha pretensões de consistência e coerência nas decisões em um Estado de Direito. A estabilidade que se espera do Direito não significa a imutabilidade do jurídico, no entanto tampouco aconselha uma mudança frequente no Direito. $\mathrm{Na}$ verdade, o reconhecimento explícito da possibilidade de revisão jurisprudencial aumenta a transparência do Direito, uma vez que permite a ocorrência de argumentos pela ou contra a mudança, os quais devem ser sinceramente considerados pelo órgão judicial, na medida em que este deve apresentar razões públicas pela alteração ou manutenção do anteriormente decidido. $^{255}$

No tocante ao locus do STF na democracia constitucional, o desenho institucional atribuído ao órgão na $\mathrm{CR} / 88$ leva a crer que há mais de uma função para os precedentes produzidos pelo Tribunal. Para além das particularidades inevitáveis de uma Corte Constitucional em cada país, fruto da cultura jurídica local, Marcos Paulo Veríssimo entende haver um quadro de "anormalidade" (sem precedentes ou congêneres mundiais) em relação às competências e carga de trabalho, o que sugeriria um ativismo judicial "à brasileira", por sua vez marcado por dois aspectos: a "disparidade imensa entre o número de casos lançados ao STF, o número de casos 'formalmente resolvidos' por ele a cada ano, e o número de casos que efetivamente geram discussões sofisticadas de constitucionalidade no Plenário" ${ }^{256}$; e a “imensa resistência que temos em outorgar ao STF poderes efetivos de concentração das decisões sobre constitucionalidade" ${ }^{257}$, notadamente no exercício formal da competência recursal em sede de controle difuso. Por conseguinte, há uma expectativa híbrida ${ }^{258}$ e

\footnotetext{
254 SCHAUER, Frederick. Precedent. In: Stanford Law Review, Palo Alto-EUA, v. 39, n. 571, fev. 1987, pp. 571-605, pp. 572-573.

${ }^{255}$ WALDRON, Jeremy. Stare Decidis and The Rule of Law: a layered approach. In: Michigan Law Review, Michigan-EUA, n. 111, Out. 2012, pp. 1-31, pp. 27-28.

${ }^{256}$ VERÍSSIMO, Marcos Paulo. A Constituição de 1988, Vinte Anos Depois: suprema corte e ativismo judicial “à brasileira”. In: Revista Direito GV, São Paulo, v. 4, n. 2, jul./dez. 2008, pp. 407-440, p. 422.

${ }^{257}$ VERÍSSIMO, Marcos Paulo. A Constituição de 1988, Vinte Anos Depois: suprema corte e ativismo judicial “à brasileira”. In: Revista Direito GV, São Paulo, v. 4, n. 2, jul./dez. 2008, pp. 407-440, p. 422.

258 “Assim, se de um lado gerou um sistema especialmente aberto à participação de atores sociais na jurisdição constitucional, com conseqüente ampliação do papel político institucional do STF (Vieira, 2002), não permitiu, por outro, que esse tribunal pudesse exercer qualquer papel relevante de uniformização do direito no uso de sua competência recursal extraordinária ligada ao sistema de controle difuso. Isso, aliado à existência de uma constituição vasta e por vezes contraditória, gerou um ambiente em que a jurisdição constitucional tornou-se especialmente caracterizada por incertezas, processos contraditórios de aplicação e tratamentos por vezes desiguais de situações que deveriam merecer tratamento jurídico uniforme." (VERÍSSIMO, Marcos Paulo. A Constituição de 1988, Vinte Anos Depois: suprema corte e ativismo judicial "à brasileira". In: Revista Direito GV, São Paulo, v. 4, n. 2, jul./dez. 2008, pp. 407-440, p. 424)
} 
paradoxal $^{259}$ em relação ao STF, isto é, como Corte de Cassação, praticamente uma quarta instância de todo o sistema judicial, e Corte Constitucional, com vistas a estabilizar a interpretação constitucional sobre o texto constitucional na cultura jurídica e para a comunidade política em geral.

Na qualidade de instância recursal, os precedentes do STF desempenham uma função de filtro ${ }^{260}$ para dar conta do volume de feitos anualmente lançados a esse Tribunal. Nesse sentido, findam-se formalmente centenas de milhares de processos, principalmente na via do recurso extraordinário, assim como se aumenta a eficiência dos procedimentos decisórios do órgão judicial. Ressalta-se que a vinculação aos precedentes nesse escopo decorre da constante jurisprudencial ou jurisprudência persistente, e não de uma decisão passada específica, isto é, a força de autoridade dos precedentes advém do constrangimento que as linhas consolidadas de decisões exercem sobre o juiz.

Na espacialidade do STF, a particularidade em relação aos tribunais congêneres emana das faculdades atribuídas ao Ministro Relator ${ }^{261}$. Como resultante, tem-se uma simples reiteração do já estabelecido nas decisões passadas, sem qualquer tipo de reavaliação sobre a aplicabilidade dos precedentes ao caso concreto ou adequação do raciocínio anteriormente adotado ao caso em julgamento.

\footnotetext{
259 "O fato de possuir uma corte suprema ativista não chegaria, por si só, a tornar o caso brasileiro uma espécie de anomalia entre as nações ocidentais, já que o crescente ativismo das cortes supremas e constitucionais tem sido um fenômeno relativamente global. No entanto, o que torna o caso brasileiro anômalo é o fato de essa corte ser, também, a mais produtiva do País (certamente, uma das mais produtivas do mundo), sobretudo quando se considera o número de casos julgados ao ano por magistrado." (VERÍSSIMO, Marcos Paulo. A Constituição de 1988, Vinte Anos Depois: suprema corte e ativismo judicial "à brasileira". In: Revista Direito GV, São Paulo, v. 4, n. 2, jul./dez. 2008, pp. 407-440, p. 424)

260 "A jurisprudência dominante, nesse sentido, é aplicada de modo quase automático, não havendo a identificação de um precedente em particular que funcione como orientador das novas decisões, mas diversos precedentes que em conjunto influenciam a tomada de decisão. As linhas decisórias dessa jurisprudência, os posicionamentos que são repetidos sucessivamente, acabam se destacando dos precedentes que lhes deram origem, passando a ter 'vida própria', e são aplicadas independente dos casos individuais que as geraram. O que se retira desses precedentes para aplicação futura é o posicionamento final, a solução encontrada para os casos concretos, não havendo necessidade de se fazer referência aos elementos fáticos presentes nos precedentes ou mesmo ao raciocínio construído neles. O que importa, para cumprir o objetivo da diminuição da quantidade de casos e para o aumento da eficiência do tribunal, é a solução pontual dessas questões, que com o apoio na legislação processual pode ser determinada individualmente por cada ministro em seu próprio gabinete, acelerando o processo decisório e conferindo eficiência à prestação jurisdicional." (VODJVODIC, Adriana de Moraes. Precedente e Argumentação no Supremo Tribunal Federal: entre a vinculação ao passado e a sinalização para o futuro. 269 f. Tese de Doutorado - Faculdade de Direito, Universidade de São Paulo, São Paulo, 2012, p. 106.)

${ }^{261}$ Nos termos do art. $21, \S 1^{\circ}$, do RISTF, "Poderá o(a) Relator(a) negar seguimento a pedido ou recurso manifestamente inadmissível, improcedente ou contrário à jurisprudência dominante ou a Súmula do Tribunal, deles não conhecer em caso de incompetência manifesta, encaminhando os autos ao órgão que repute competente, bem como cassar ou reformar, liminarmente, acórdão contrário à orientação firmada nos termos do art. 543-B do Código de Processo Civil."
} 
Por outro lado, na qualidade de Corte Constitucional, o STF colabora para a construção do conteúdo das normas constitucionais naqueles casos mais complexos ou que não houve a consolidação de uma jurisprudência dominante. Logo, as decisões são tomadas de forma colegiada e refletem a interpretação do Tribunal acerca de dispositivos normativos, inclusive de índole constitucional. Não há propriamente uma solução pronta, de modo que as decisões pretéritas são utilizadas como topoi para a construção do deslinde da controvérsia, com potencialidade de se tornar um novo precedente, que, por sua vez, irá orientar as futuras decisões de todo o sistema judicial, demais atores institucionais e sociedade civil.

Nesses termos, a disputa pela significação dos tipos e conceitos jurídicos se desloca do ambiente legislativo para a jurisdição constitucional. Há, por conseguinte, uma acentuação do precedente na dinâmica de criação judicial do Direito. Como aplicador das normas jurídicas, o Poder Judiciário complementa o trabalho do parlamentar, justamente no momento em que interpreta/aplica o Direito com vistas a resolver litígios. ${ }^{262}$ No pensamento de Conrado Hübner, pode-se considerar, ao lado do "STF Juiz", o STF como Colegislador, pois atribuir significado à Constituição é uma atividade essencialmente construtiva, assim se criam normas jurídicas e regulam-se os atos dos outros atores políticos. Inova, portanto, no ordenamento jurídico, o que, em uma visão estanque de separação dos poderes, traduz-se em uma atividade típica da função legislativa. ${ }^{263}$

Em via conclusiva desse excurso, vale a transcrição de excerto sintético da tese de doutorado de Adriana Vodjovic a respeito do tema:

\begin{abstract}
São esses dois papéis atribuídos aos precedentes que serão usados como parâmetro na observação da jurisprudência do Supremo. Do lado de um tribunal responsável pela solução de problemas de massa, encontra-se a tarefa de uniformização dos posicionamentos na consolidação de uma jurisprudência que reflita a quantidade de precedentes decididos, e cujo objetivo está na diminuição da carga de trabalho desempenhado pela corte com vistas a uma maior eficiência na solução das controvérsias individuais. Em outro sentido, no lado de uma corte constitucional, é esperada a construção de uma jurisprudência que não se baseie na reiteração das soluções adotadas em precedentes, mas que se aproprie do raciocínio desenvolvido neles para a elaboração de decisões em situações inéditas ou pouco exploradas pelo
\end{abstract}

\footnotetext{
262 RODRIGUEZ, José Rodrigo; PÜSCHEL, Flavia Portella; MACHADO, Marta Rodriguez de Assis. O Raciocínio Jurídico-dogmático e suas Relações com o Funcionamento do Poder Judiciário e a Democracia. In: Anais do $3^{\circ}$ Congresso Latino Americano do Ciência Política, Associação Latino-Americana de Ciência Política, Campinas, Brasil, 2006.

${ }^{263}$ MENDES, Conrado Hübner. Colegisladores. In: O Estado de São Paulo, p. A2, Publ. 02.05.2012. Nesse ponto, a coerência do Direito se revela fundamental, porquanto "Reconhece-se que, num certo sentido, Direito novo está sendo criado, mas com base no Direito existente, porque é inteiramente coerente com ele, e por isso mesmo, está dentro de sua moldura de referência." (MACCORMICK, Neil. Retórica e o Estado de Direito. Trad. Conrado Hübner Mendes. Rio de Janeiro: Elsevier, 2008, p. 267)
} 
tribunal. $^{264}$

Neste momento, a narrativa pretendida se refere à segunda função atribuída aos precedentes do STF, na qualidade de Corte Constitucional. Por conseguinte, recorre-se à literatura jurídica especializada ${ }^{265}$ e ao inteiro teor do acórdão exarado na ADI-MC 4.048, com a finalidade de identificar os julgados paradigmáticos para a narrativa jurisprudencial acerca do controle de constitucionalidade de normas jurídicas.

Nada obstante haja variações em direções aditivas ou supressivas, parece ser inequívoca a identificação de dois entendimentos do STF acerca da possibilidade de controle abstrato de constitucionalidade de leis orçamentárias, anteriores ao advento da ADI-MC precitada, textualizados nos acórdãos das ADI-QO $1.640^{266}$, de relatoria do Ministro Sydney Sanches, e ADI $2.925^{267}$, de relatoria da Ministra Ellen Gracie e com acórdão redigido pelo Ministro Marco Aurélio. Por isso, a narrativa proposta se concentrará nesses dois julgados, valendo-se unicamente como critérios o reconhecimento da práxis jurídica a um julgado como precedente e as necessidades particulares da presente pesquisa.

Na primeira decisão, tratava-se de uma questão de ordem proposta pelo Ministro

\footnotetext{
${ }^{264}$ VODJVODIC, Adriana de Moraes. Precedente e Argumentação no Supremo Tribunal Federal: entre a vinculação ao passado e a sinalização para o futuro. 269 f. Tese de Doutorado - Faculdade de Direito, Universidade de São Paulo, São Paulo, 2012, p. 116.

${ }^{265}$ Vide os seguintes artigos em duas relevantes obras coletivas de Direito Financeiro: FUX, Luiz. Orçamento Público na Jurisprudência do STF: a possibilidade de controle judicial, a autonomia constitucional orçamentária e a problemática do orçamento participativo. In: GOMES, Marcus Lívio; ABRAHAM, Marcus; TORRES, Heleno Taveira (coords.). Direito Financeiro na Jurisprudência do Supremo Tribunal Federal: homenagem ao Ministro Marco Aurélio. Curitiba: Juruá, 2016. CONTI, José Maurício. O Supremo Tribunal Federal e o Controle de Constitucionalidade em Matéria Orçamentária. In: GOMES, Marcus Lívio; ABRAHAM, Marcus; TORRES, Heleno Taveira (coords.). Direito Financeiro na Jurisprudência do Supremo Tribunal Federal: homenagem ao Ministro Marco Aurélio. Curitiba: Juruá, 2016. ASSONI FILHO, Sérgio. Controle de Constitucionalidade da Lei Orçamentária. In: CONTI, José Maurício; SCAFF, Fernando Facury (coords.). Orçamentos Públicos e Direito Financeiro. São Paulo: Revista dos Tribunais, 2011. CORREIA NETO, Celso de Barros. O Orçamento Público e o Supremo Tribunal Federal. In: CONTI, José Maurício; SCAFF, Fernando Facury (coords.). Orçamentos Públicos e Direito Financeiro. São Paulo: Revista dos Tribunais, 2011. NEME, Eliana Franco; ARAUJO, Luiz Alberto David. O Controle de Constitucionalidade Concentrado de Normas Orçamentárias. In: CONTI, José Maurício; SCAFF, Fernando Facury (coords.). Orçamentos Públicos e Direito Financeiro. São Paulo: Revista dos Tribunais, 2011. Ademais, confiram-se as seguintes teses de doutorado: ROCHA, Francisco Sérgio Silva. Controle do Orçamento Público e o Juízo de Constitucionalidade: problemas na execução e na inexecução orçamentária. 343 f. Tese de Doutorado - Instituto de Ciências Jurídicas, Universidade Federal do Pará, Belém-PA, Brasil, 2010; CHRISTOPOULOS, Basile Georges Campos. Controle de Constitucionalidade de Normas Orçamentárias: o uso de argumentos consequencialistas nas decisões do Supremo Tribunal Federal. 240 f. Tese de Doutorado - Faculdade de Direito, Universidade de São Paulo, São Paulo-SP, Brasil, 2014.

${ }^{266}$ BRASIL. SUPREMO TRIBUNAL FEDERAL. Questão de Ordem na Ação Direta de Inconstitucionalidade 1.640, Plenário, Rel. Min.Sydney Sanches, j. 12.02.1998, Publ. DJ em 03.04.1998, pp. 68-81.

${ }^{267}$ BRASIL. SUPREMO TRIBUNAL FEDERAL. Ação Direta de Inconstitucionalidade 2.925, Plenário, Rel. Min. Ellen Gracie, Rel. p/ Ac. Marco Aurélio, j. 19.12.2003, Publ. DJ 04.03.2005, pp. 112-188.
} 
Relator Sydney Sanches em sessão plenária, sob a presidência do Ministro Celso de Mello, para que o colegiado deliberasse acerca do cabimento de ADI em face da LOA federal para o exercício financeiro de $1997^{268}$. A ADI 1.640 foi proposta pelos seguintes partidos políticos: Partido dos Trabalhadores (PT), Partido Comunista do Brasil (PC do B), Partido Democrático Trabalhista (PDT), Partido Socialista Brasileiro (PSB) e Partido Verde (PV).

Em específico, os Requerentes alegaram a inconstitucionalidade da utilização de recursos da Contribuição Provisória sobre Movimentação ou Transmissão de Valores e de Créditos e Direitos de Natureza Financeira (CPMF) para o pagamento de dívidas e encargos da Dívida Pública da União, o que ofenderia o art. 74 da ADCT, com redação dada pela EC 12/96, porquanto as verbas arrecadadas em função desse tributo deveriam ser utilizadas exclusivamente nas ações de saúde.

Houve, ainda, pedido de concessão de medida cautelar para sustar os efeitos da referida destinação.

Os Requeridos, por sua vez, alegaram a higidez do processamento legislativo correspondente ao projeto de LOA, assim como a legítima utilização dos recursos públicos para saldar dívidas do Ministério da Saúde relacionadas ao Fundo de Amparo do Trabalhador. Em preliminar, a Presidência da República suscitou a impossibilidade de conhecimento de ADI em face de ato de efeitos concretos.

Estiveram presentes à sessão os Ministros Celso de Mello (Presidente), Moreira Alves, Néri da Silveira, Sydney Sanches, Octavio Gallotti, Sepúlveda Pertence, Carlos Velloso, Marco Aurélio, Maurício Corrêa e Nelson Jobim.

A preliminar invocada pela PR foi acolhida à unanimidade pelo Tribunal Pleno do $\mathrm{STF}^{269}$, porque se entendeu que não houve a impugnação de um ato normativo, o que denota a

\footnotetext{
${ }^{268}$ BRASIL. PRESIDÊNCIA DA REPÚBLICA. Lei 9.438, de 26 de fevereiro de 1997. Estima a Receita e fixa a Despesa da União para o exercício financeiro de 1997. DOU, Seção 1, Publ. em 27.02.2007, p. 11.769.

269 "DIREITO CONSTITUCIONAL E TRIBUTÁRIO. CONTRIBUIÇÃO PROVISÓRIA SOBRE MOVIMENTAÇÃO FINANCEIRA - C.P.M.F. AÇÃO DIRETA DE INCONSTITUCIONALIDADE 'DA UTILIZAÇÃO DE RECURSOS DA C.P.M.F.' COMO PREVISTA NA LEI No N $^{\circ}$ 9.438/97. LEI ORÇAMENTÁRIA: ATO POLÍTICO-ADMINISTRATIVO - E NÃO NORMATIVO. IMPOSSIBILIDADE JURÍDICA DO PEDIDO: ART. 102, I, 'A', DA C.F. 1. Não há, na presente Ação Direta de Inconstitucionalidade, a impugnação de um ato normativo. Não se pretende a suspensão cautelar nem a declaração final de inconstitucionalidade de uma norma, e sim de uma destinação de recursos, prevista em lei formal, mas de natureza e efeitos político-administrativos concretos, hipótese em que, na conformidade dos precedentes da Corte, descabe o controle concentrado de constitucionalidade como previsto no art. 102, I, "a", da Constituição Federal, pois ali se exige que se trate de ato normativo. Precedentes. 2. Isso não impede que eventuais prejudicados se valham das vias adequadas ao controle difuso de constitucionalidade, sustentando a inconstitucionalidade da destinação de recursos, como prevista na Lei em questão. 3. Ação Direta de
} 
impossibilidade jurídica do pedido.

Segundo o Ministro Relator, os Requerentes pretendiam a declaração de inconstitucionalidade da destinação de recursos, prevista em lei formal, mas de natureza e efeitos políticos-administrativos concretos, hipótese essa que não se amolda ao permissivo constitucional do art. 102, I, “a”, da CR/88, nos termos da jurisprudência do STF.

Lateralmente, o Ministro Relator asseverou que "nada impede que eventuais prejudicados se valham das vias adequadas ao controle difuso de constitucionalidade, sustentando a inconstitucionalidade da destinação de recursos, como prevista na Lei em questão.,"270

Na segunda decisão, o Plenário do STF se dividiu tanto na admissibilidade quanto no mérito da ADI 2.925, sendo, inclusive, derrotada a Ministra Relatora Ellen Gracie. Tratava-se de ADI ajuizada pela Confederação Nacional do Transporte em face do art. $4^{\circ}$ da LOA da União para o exercício financeiro de $2003^{271}$. Esse dispositivo autorizava a utilização de $10 \%$ dos recursos advindos da Contribuição de Intervenção no Domínio Econômico incidente sobre atividades de importação ou comercialização de petróleo e seus derivados, gás natural e seus derivados e álcool combustível (CIDE-combustível) para a abertura de créditos suplementares, mediante decreto do Poder Executivo.

A Requerente sustentou a vinculação constitucional desse imposto a apenas três finalidades taxativamente dispostas no artigo $177, \S 4^{\circ}$, II, da CR/88 272 . Logo, seria inconstitucional a destinação discricionária das verbas arrecadas em decorrência desse tributo para suplementar dotações orçamentárias preexistentes.

Após a prestação de informações por parte dos órgãos requeridos, já sob a vigência da

Inconstitucionalidade não conhecida, prejudicado, pois, o requerimento de medida cautelar. Plenário. Decisão unânime."

${ }^{270}$ BRASIL. SUPREMO TRIBUNAL FEDERAL. Questão de Ordem na Ação Direta de Inconstitucionalidade 1.640, Plenário, Rel. Min.Sydney Sanches, j. 12.02.1998, Publ. DJ em 03.04.1998, pp. 68-81, p. 80.

${ }^{271}$ BRASIL. PRESIDÊNCIA DA REPÚBLICA. Lei 10.640, de 14 de janeiro de 2003. Estima a receita e fixa a despesa da União para o exercício de 2003. Diário Oficial da União, Seção 1, Publ. em 15.01.2003, p. 1.

$272 \S 4^{\circ}$ A lei que instituir contribuição de intervenção no domínio econômico relativa às atividades de importação ou comercialização de petróleo e seus derivados, gás natural e seus derivados e álcool combustível deverá atender aos seguintes requisitos: II - os recursos arrecadados serão destinados: a) ao pagamento de subsídios a preços ou transporte de álcool combustível, gás natural e seus derivados e derivados de petróleo; b) ao financiamento de projetos ambientais relacionados com a indústria do petróleo e do gás; c) ao financiamento de programas de infra-estrutura de transportes. 
Lei federal 9.868/99 273 , tanto a AGU (defensor legis) quanto a PGR (custos legis) opinaram pela improcedência da ação, sendo novamente expendida a preliminar do não conhecimento de processo objetivo em face de lei formal que veicule ato de efeitos concretos.

Estiveram presentes na Sessão do dia 11.12.2003, na qual se deliberou sobre a admissibilidade da ação, os Ministros Maurício Corrêa (Presidente), Sepúlveda Pertence, Celso de Mello, Carlos Velloso, Marco Aurélio, Nelson Jobim, Ellen Gracie, Gilmar Mendes, Cezar Peluso, Carlos Britto e Joaquim Barbosa, com a ausência justificada do Ministro Nelson Jobim. Na Sessão plenária do dia 19.12.2003, em que o mérito da ADI foi debatido, estiveram presentes todos os Ministros integrantes do STF à época.

No sentido da jurisprudência anterior, a Ministra Relatora afirmou que o objeto de controle seria ato específico de autorização para a abertura de créditos suplementares. Portanto, em que pese sua forma de lei, esses atos se caracterizariam como normas individuais de autorização que tornam viável a modificação na fixação das despesas públicas ao longo do exercício financeiro do ano-base. "Assim sendo, faltam ao ato impugnado os requisitos de abstração e generalidade necessários à deflagração, nesta Corte, da fiscalização concentrada de constitucionalidade pela via da ação direta",274.

Como reforço argumentativo, a Ministra Ellen Gracie sustentou não haver incompatibilidade entre a espécie tributária da contribuição, cuja destinação é vinculada, e a sistemática da abertura de créditos suplementares. Demais disso, declarar a inconstitucionalidade parcial do dispositivo impugnado para excluir a CIDE-combustível da norma representaria afronta ao princípio da separação dos poderes, ao ver da Ministra Relatora, na medida em que modificaria o sentido e o alcance da autorização reconhecida pelo Poder Legislativo em sede de lei formal.

$\mathrm{Na}$ admissibilidade, coube ao Ministro Marco Aurélio abrir divergência, ao fundamento de que o confronto entre a lei orçamentária e a Constituição da República seria frontal e direto. Em termos consequencialistas, asseverou que "Se entendermos caber a generalização, afastando por completo a possibilidade do controle concentrado, desde que o ato impugnado seja lei orçamentária, terminaremos por colocar a lei orçamentária acima da

\footnotetext{
273 BRASIL. PRESIDÊNCIA DA REPÚBLICA. Lei 9.868, de 10 de novembro de 1999. Dispõe sobre o processo e julgamento da ação direta de inconstitucionalidade e da ação declaratória de constitucionalidade perante o Supremo Tribunal Federal. Diário Oficial da União, Seção 1, Publ. 11.11.1999, p. 1.

${ }^{274}$ BRASIL. SUPREMO TRIBUNAL FEDERAL. Ação Direta de Inconstitucionalidade 2.925, Plenário, Rel. Min. Ellen Gracie, Rel. p/ Ac. Marco Aurélio, j. 19.12.2003, Publ. DJ 04.03.2005, pp. 112-188, p. 121.
} 
Carta da República" ${ }^{275}$. Assim, a cognoscibilidade de ADI em face de lei orçamentária seria questão heurística.

O debate que se sucedeu no colegiado consistiu em saber se a norma impugnada teria grau de abstração e generalidade suficiente para ser conhecida em âmbito de fiscalização abstrata de constitucionalidade. ${ }^{276}$ Com exceção da Ministra Relatora, acordou-se que o dispositivo atacado se traduziria em uma autorização abstrata à PR para abrir créditos suplementares em termos potencialmente contraditórios à norma constitucional.

No mérito, a discussão se pautou no cotejo entre a LOA precitada, a LRF e o parâmetro constitucional invocado. A corrente vencida defendeu que o arcabouço normativo já não permitiria a utilização dos recursos emanados da CIDE-combustível para a abertura de créditos suplementares. Isso porque o parágrafo único do artigo $8^{\circ}$ da LRF dispõe o seguinte: "Os recursos legalmente vinculados a finalidade específica serão utilizados exclusivamente para atender ao objeto de sua vinculação, ainda que em exercício diverso daquele em que ocorrer o ingresso".

Basicamente, a Ministra Relatora alegou ser incabível a pretensão de compelir o Poder Executivo a utilizar recursos contingenciados por crédito suplementar, pois significaria uma interferência judicial na seara das opções de política governamental e um desvirtuamento da

\footnotetext{
275 BRASIL. SUPREMO TRIBUNAL FEDERAL. Ação Direta de Inconstitucionalidade 2.925, Plenário, Rel. Min. Ellen Gracie, Rel. p/ Ac. Marco Aurélio, j. 19.12.2003, Publ. DJ 04.03.2005, pp. 112-188, p. 123.

${ }^{276}$ Importa destacar que em explicação de voto do Ministro Carlos Britto, o Ministro Gilmar Mendes buscou afirmar sua posição doutrinária pretérita, a qual seria posteriormente acolhida na ADI-MC, restando claro os diferentes pontos de vista acerca do art. 102, I, "a", da CR/88. Confira-se o referido debate: "SENHOR MINISTRO CARLOS AYRES BRITTO: A abstratividade, diz a teoria toda do Direito, implica uma renovação, não digo perene, porque, aqui, está limitada por um ano, mas uma renovação duradoura entre a hipótese de incidência da norma e a sua conseqüência. E me parece que, neste caso, o Ministro Sepúlveda Pertence colocou muito bem em evidência, durante um ano inteiro o Presidente da República fica autorizado a aplicar e reaplicar a lei a seu talante, claro que observados aqueles limites e condições. Acho que a abstratividade está presente, também.
}

O SENHOR MINISTRO GILMAR MENDES - Na verdade, o conceito de controle abstrato - pelo menos o desenvolvido no Direito europeu -, que contrapõe-se ao chamado controle concreto, diz respeito simplesmente à se postulação de proteção a uma posição jurídico-positiva. Tão-somente isso! Não está associado sequer a esse caráter genérico e abstrato.

O SENHOR MINISTRO SEPÚLVEDA PERTENCE - Não, aí é o problema de que - como o Tribunal construiu - o ato normativo deve ter, ele próprio, um certo grau de abstração.

O SENHOR MINISTRO GILMAR MENDES - Sim, mas estou dizendo, o nome controle abstrato está associado, propriamente, a essa contraposição com o chamado controle concreto.

O SENHOR MINISTRO SEPÚLVEDA PERTENCE - É mais de distinção entre a norma geral e a norma concreta na teoria kelseniana.

O SENHOR MINISTRO CARLOS BRITTO: Lourival Vilanova diria que o descritor e o prescritor da norma se co-implicam duradouramente, um atrai o outro. O descritor é o antecedente da norma, é a hipótese de incidência, e o prescritor é o conseqüente da norma." (BRASIL. SUPREMO TRIBUNAL FEDERAL. Ação Direta de Inconstitucionalidade 2.925, Plenário, Rel. Min. Ellen Gracie, Rel. p/ Ac. Marco Aurélio, j. 19.12.2003, Publ. DJ 04.03.2005, pp. 112-188, pp. 133-134.) 
finalidade do instrumento orçamentário. Segundo a Relatora, visava-se tutelar direito de forma mandamental e preventiva, por sua vez não cabível em sede de ADI.

Do lado da corrente vencedora, não se vislumbrou na lei impugnada a segurança de prevenção contra a alocação de recursos em reserva de contingência (dotação orçamentária inespecífica), o que seria um desvio finalístico às destinações constitucionais do produto da arrecadação da CIDE-combustível.

A propósito, integraram a maioria os Ministros Carlos Britto, Cezar Peluso, Gilmar Mendes, Marco Aurélio, Carlos Velloso e Maurício Corrêa (Presidente), ao passo que remanesceram vencidos a Ministra Relatora Ellen Gracie e os Ministros Joaquim Barbosa, Nelson Jobim e Sepúlveda Pertence. ${ }^{277}$

Em suma, a narrativa jurisprudencial acerca do cabimento da ADI em face de lei orçamentária centrou-se nos atributos da generalidade e da abstração dos atos normativos, sendo que o segundo julgamento foi reconhecido como exceção à regra que se traduz na impossibilidade da fiscalização abstrata de constitucionalidade em relação a atos de efeitos concretos.

\subsubsection{Uma visão do julgamento da ADI-MC 4.048}

Intenta-se, aqui, realizar uma descrição sucinta em relação ao julgamento da medida cautelar na ADI 4.048, de relatoria do Ministro Gilmar Mendes, ajuizada pelo Partido da Social Democracia Brasileira (PSDB) em 12.3.2008, cujo objeto era a MP 405, editada e publicada em 18.12.2007, posteriormente convertida na Lei 11.658/2008, sem alteração substancial. Ademais, a impugnação adotou como parâmetros os artigos 62, §1 , I, “d”, e 167, $\S 3^{\circ}$, da CR/88.

A propósito, a MP em tela abriu crédito extraordinário em favor da Justiça Eleitoral e

\footnotetext{
277 “PROCESSO OBJETIVO - AÇÃO DIRETA DE INCONSTITUCIONALIDADE - LEI ORÇAMENTÁRIA. Mostra-se adequado o controle concentrado de constitucionalidade quando a lei orçamentária revela contornos abstratos e autônomos, em abandono ao campo da eficácia concreta. LEI ORÇAMENTÁRIA CONTRIBUIÇÃO DE INTERVENÇÃO NO DOMÍNIO ECONÔMICO - IMPORTAÇÃO E COMERCIALIZAÇÃO DE PETRÓLEO E DERIVADOS, GÁS NATURAL E DERIVADOS E ÁLCOOL COMBUSTÍVEL - CIDE - DESTINAÇÃO - ARTIGO 177, § 4º DA CONSTITUIÇÃO FEDERAL. É inconstitucional interpretação da Lei Orçamentária $\mathrm{n}^{\circ}$ 10.640, de 14 de janeiro de 2003, que implique abertura de crédito suplementar em rubrica estranha à destinação do que arrecadado a partir do disposto no $\S 4^{\circ}$ do artigo 177 da Constituição Federal, ante a natureza exaustiva das alíneas "a", "b" e "c" do inciso II do citado parágrafo."
} 
de diversos órgãos do Poder Executivo, no valor global de $\mathrm{R} \$$ 5.455.677.660,00, para os fins que especifica nos Anexos I e III do próprio diploma normativo. Nesses termos, o PR à época, Luiz Inácio Lula da Silva, valeu-se de competência excepcional para editar medidas provisórias acerca de matéria orçamentária.

A discussão da ADI-MC em comento é justamente acerca da única hipótese que excetua a impossibilidade de a PR dispor sobre leis orçamentárias em medida provisória, nos termos do art. $\$ 3^{\circ}$ do art. 167 da $\mathrm{CR} / 88^{278}$. Logo, se além da relevância e da urgência da situação jurídica também for observada a necessidade de atendimento de despesas imprevisíveis e urgentes, torna-se constitucionalmente viável à abertura de crédito extraordinário por intermédio de MP.

Nesse quadro fático-normativo, o Requerente argumentou pela inconstitucionalidade do diploma normativo, porquanto não estariam presentes, na espécie, a imprevisibilidade e a urgência da despesa pública. Pugnou-se, ainda, pelo cabimento de ADI em face de normas de caráter orçamentário, uma vez que se estava a discutir o enquadramento de um determinado crédito na categoria constitucional "extraordinário", não se tratando, portanto, de um debate acerca do conteúdo de um crédito extraordinário em si mesmo. Por fim, requereu-se a concessão de medida cautelar, com base no art. 10 da Lei 9.868/1999.

No curso do julgamento, a MP fora convertida na Lei 11.658/2007, de modo que o requerente aditou o pedido inicial para também englobar essa lei. Tal pleito foi atendido pelo Ministro Relator, com fundamento na jurisprudência do STF, segundo a qual a lei de conversão não convalida os vícios eventualmente existentes na MP, bem como não houve alterações substanciais entre os diplomas normativos no caso concreto.

Visto isso, destaca-se que a ADI fora apregoada no dia 17.04.2008, iniciando-se o julgamento com a leitura do relatório e sustentações orais do causídico do partido requerente e do AGU. Em seguida, julgou-se a questão preliminar de conhecimento e o mérito da ação. Enfim, o feito se deu por findo em 14.05.2008. ${ }^{279}$

Conforme já posto, as questões principais do julgado podem ser divididas em dois

\footnotetext{
278 "A abertura de crédito extraordinário somente será admitida para atender a despesas imprevisíveis e urgentes, como as decorrentes de guerra, comoção interna ou calamidade pública, observado o disposto no art. 62.”

279 "Retificada a proclamação do dia 17 de abril do corrente para constar que o Tribunal, preliminarmente, conheceu da ação, vencido o Senhor Ministro Cezar Peluso. Em seguida, prosseguindo no julgamento, o Tribunal, por maioria, concedeu a liminar, nos termos do voto do relator, Ministro Gilmar Mendes (Presidente), vencidos os Senhores Ministros Ricardo Lewandowski, Joaquim Barbosa, Cezar Peluso, Ellen Gracie e Menezes Direito. Plenário, 14.05.2008” (BRASIL. Ibid., p. 191).
} 
grupos os quais coincidem com os planos processuais de admissibilidade e mérito. Quanto ao cabimento, explicitamente se revisou antiga jurisprudência do Supremo Tribunal Federal, segundo a qual era incabível a interposição de ações típicas de controle abstrato de constitucionalidade para impugnar normas de índole orçamentária.

Relativamente ao mérito, analisou-se a possibilidade do STF fiscalizar a atividade legislativa do Chefe do Poder Executivo em sede de MP, especialmente no tocante aos limites constitucionais para a abertura de crédito extraordinário. Tais limites seriam sindicados a partir do cotejo da realidade empírica do Brasil no momento da edição da MP com os pressupostos constitucionais para promover essas medidas excepcionais, conforme previsão do Poder Constituinte na CR/88.

O principal argumento lançado pelo Ministro Relator ${ }^{280}$ para o conhecimento da ADI em questão é de foro consequencialista, pois se reputa insegura a jurisprudência anterior da Corte, além disso se empresta significado substancial a elementos muitas vezes acidentais, tais como generalidade, impessoalidade e abstração dos atos legislativos.

Assim, não haveria razão lógico-jurídica para impedir a aferição da legitimidade das leis formais no controle abstrato de normas. Ademais, o STF estaria diante de controvérsia constitucional suscitada em abstrato, então pouco importaria o caráter geral ou específico, concreto ou abstrato, do objeto do processo objetivo de constitucionalidade.

Nesse sentido, os atributos da generalidade e abstração somente seriam necessários para ato normativo a que se refere o art. 102, I, "a", da CR/88, de modo que esse fosse equiparável a uma lei em sentido formal, de maneira a viabilizar a abertura da via do controle abstrato no STF.

Resta dizer que essa corrente restou vencedora na Corte. Nas palavras da Ministra Cármen Lúcia, votar pelo não cabimento do pedido seria "criar um cavalo de Tróia no sistema de controle de constitucionalidade. Estaríamos lidando com, às vezes, a execução que vem numa lei, e aquilo que é muito maior ficaria inexpugnável."281

A corrente vencida votou pelo não conhecimento da demanda. No pensamento do Ministro Cezar Peluso, o objeto da ação "Trata-se, a meu ver, de ato complexo em que se

280 Cumpre-se observar que Relator da ADI-MC 4.048, Ministro Gilmar Mendes, já havia exposto fundamentação rigorosamente idêntica à colocada no voto no bojo de sua tese de doutoramento, ao tratar do controle de constitucionalidade no Brasil e as leis de efeito concreto. Cf. MENDES, Gilmar Ferreira. Jurisdição Constitucional: o controle abstrato de normas no Brasil e na Alemanha. São Paulo: Saraiva, 1996, pp. 157-159.

${ }^{281}$ BRASIL. SUPREMO TRIBUNAL FEDERAL. Medida Cautelar na Ação Direta de Inconstitucionalidade 4.048, Plenário, Rel. Min. Gilmar Mendes, j. 14.05.2008, Publ. DJe 157, em 22.08.2008, pp. 55-192, p. 90. 
pede a participação do Legislativo. É uma participação que se manifesta a título formal de lei. Mas é simplesmente autorização para a prática de um ato que pede a colaboração do Legislativo."282

Por sua vez, Tribunal dividiu-se quanto ao mérito e por resultado de 6 a 5 assentou-se a procedência do pedido na ADI-MC em comento. Foram vencedores os Ministros Gilmar Mendes (Relator e Presidente), Eros Grau, Cármen Lúcia, Carlos Britto e Marco Aurélio; ao passo que remanesceram vencidos os Ministros Ricardo Lewandowski, Joaquim Barbosa, Cezar Peluso, Ellen Gracie e Menezes Direito.

A argumentação esposada pelo Ministro Relator Gilmar Mendes deu enfoque aos requisitos exigidos para a abertura de crédito extraordinário, a imprevisibilidade e a urgência da despesa pública. Segundo o Relator, as expressões "guerra", "comoção interna" e "calamidade pública", das quais decorreriam as despesas imprevisíveis e urgentes, oferecem densidade normativa aos critérios para ensejar a abertura dos créditos extraordinários. Noutras palavras, "ao mesmo tempo em que fixa conceitos normativos de caráter aberto e indeterminado, a Constituição oferece os parâmetros para a interpretação e aplicação desses conceitos."283

À luz da ótica constitucional, o Ministro Gilmar Mendes consignou o seguinte: "Como se pode constatar, pela leitura atenta da exposição de motivos da MP n. 405/2007, os créditos abertos são destinados a prover despesas correntes, que não estão qualificadas pela imprevisibilidade ou pela urgência." ${ }^{284}$ Nada obstante haja situações relevantes para o dispêndio de recursos públicos previstos na MP supra, v.g. redução dos riscos de introdução da gripe aviária e de outras doenças exóticas na cadeia avícola brasileira, não se preencheria o requisito da imprevisibilidade na espécie, porquanto esses aportes seriam passíveis de planejamento financeiro prévio por parte da Administração Pública.

Ademais, foi fonte de debate no curso do julgamento a configuração em concreto do papel do Supremo Tribunal Federal na qualidade de "Guardião da Constituição" da República Federativa do Brasil. Nas palavras do Relator, "É papel desta Corte assegurar a força normativa da Constituição e estabelecer limites aos eventuais excessos legislativos dos demais

\footnotetext{
282 BRASIL. SUPREMO TRIBUNAL FEDERAL. Medida Cautelar na Ação Direta de Inconstitucionalidade 4.048, Plenário, Rel. Min. Gilmar Mendes, j. 14.05.2008, Publ. DJe 157, em 22.08.2008, pp. 55-192, p. 93.

283 BRASIL. SUPREMO TRIBUNAL FEDERAL. Medida Cautelar na Ação Direta de Inconstitucionalidade 4.048, Plenário, Rel. Min. Gilmar Mendes, j. 14.05.2008, Publ. DJe 157, em 22.08.2008, pp. 55-192, p. 69.

${ }^{284}$ BRASIL, SUPREMO TRIBUNAL FEDERAL. Medida Cautelar na Ação Direta de Inconstitucionalidade 4.048, Plenário, Rel. Min. Gilmar Mendes, j. 14.05.2008, Publ. DJe 157, em 22.08.2008, pp. 55-192, pp. 86-87.
} 
Poderes." 285

Para a corrente vencida, o pleito encontraria óbice na própria jurisprudência do Supremo Tribunal Federal, segundo a qual não caberia ao Poder Judiciário adentrar no mérito dos atos legislativos do Poder Executivo, mormente quando excepcionais, ou seja, os requisitos de "relevância" e "urgência" para a edição de uma MP tem seu conteúdo definido pelo Chefe do Executivo em atividade amplamente discricionária, a qual não caberia ao Judiciário sindicar, à luz da separação dos poderes e do regime democrático.

Assim, o Ministro Cezar Peluso desenvolveu interessante argumentação no sentido de que não há diferença metodológica na avaliação dos artigos 62 e 167 do Texto Constitucional. Ou seja, nada obstante o Constituinte tenha dado densidade normativa para "despesas emergenciais e imprevisíveis" ao listar possíveis acontecimentos, a atividade de aferição do cumprimento dos requisitos não se diferencia entre os dois dispositivos supracitados. Em termos constitucionais, essa fiscalização caberia explicitamente ao Poder Legislativo, remanescendo o Poder judicante alheio a esse tipo de movimentação institucional.

Por fim, o Ministro Peluso arrematou seu raciocínio ao dizer que a conclusão desse julgamento, a depender do resultado, provocaria a retificação ou a ratificação das limitações de competência do STF em relação às MPs, tomadas genericamente, porquanto não haveria razão lógico-jurídica para distinguir situações semelhantes.

O Ministro Ricardo Lewandowski se mostrou mais alarmante quanto ao tema, pois entendera que adotar o entendimento do Ministro Relator exigiria que a Corte Constitucional fizesse seu "dever de casa", isto é, aferisse rubrica por rubrica o preenchimento dos requisitos constitucionais para edição de medida provisória para abertura de créditos extraordinários. Em suma, eventual banalização da atividade legislativa excepcional do Executivo não teria o condão de macular na íntegra o diploma legal.

De modo lateral, visto que não interferiria diretamente nas razões de decidir do julgado, parcela significativa dos membros do Tribunal Pleno adentraram em um debate jurídico-político sobre o papel de Guardião da Constituição em âmbito orçamentário. Daí, surgiram diversas concepções acerca do papel do Estado-Juiz em uma democracia constitucional. Para o Ministro Marco Aurélio, a última palavra caberia ao Supremo Tribunal Federal, por comungar de uma concepção estrita de Supremacia Judicial, inclusive, quanto às

\footnotetext{
285 BRASIL, SUPREMO TRIBUNAL FEDERAL. Medida Cautelar na Ação Direta de Inconstitucionalidade 4.048, Plenário, Rel. Min. Gilmar Mendes, j. 14.05.2008, Publ. DJe 157, em 22.08.2008, pp. 55-192, p. 88.
} 
questões orçamentárias e financeiras.

A parte vencida utilizou-se de uma visão da separação dos poderes no Brasil para densificar suas refutações ao voto-condutor do Ministro Relator, de modo que a competência e responsabilidade pela aferição de requisitos ensejadores da medida provisória caberiam ao Poder Legislativo. Logo, asseverou-se que o Supremo Tribunal Federal estaria a anular as funções constitucionalmente delimitadas ao Parlamento e ao governo.

\subsection{Coesão, coerência e consequências da ADI-MC 4.048}

Ao adotar-se a teoria da argumentação jurídica de Neil MacCormick, concebe-se o Direito como ordem normativa institucional centrada na noção de coordenação jurídica que almeja um consenso razoável e seguro sobre as expectativas da comunidade e do sistema jurídico, tendo em conta determinado lugar e tempo, para fins de regular a sociedade que instaura essa mesma ordem. ${ }^{286}$

Nesse contexto, a força de um argumento se dá de maneira relacional ${ }^{287}$ ao seu contraponto, isto é, considera-se uma proposição adequada em relação aos contra-argumentos imagináveis. Em suma, "A opinião de alguém a respeito da força de um argumento depende de uma avaliação da força correspondente do conjunto de argumentos em contrário.,"288

Ademais, a avaliação de uma justificação judicial deve levar em conta a necessidade de reconciliação entre os topoi Estado de Direito e Caráter Argumentativo do Direito ${ }^{289}$, por

\footnotetext{
${ }^{286}$ Cf. MACCORMICK, Neil. Institutional Normative Order: a conception of Law. In: Cornell Law Review, Ithaca-NY, vol. 82, p. 1051-1070.

287 Aqui também não há separação nítida entre os componentes pragmáticos da dimensão argumentativa do Direito, isto é, retórica e dialética imbricam-se, em certo sentido, no pensamento de MacCormick, atraindo novamente as críticas de Atienza para quem "entre o proponente e o oponente de uma argumentação dialéctica existe uma interacção constante, enquanto que o auditório (o destinatário) de um discurso retórico desempenha um papel relativamente passivo no próprio processo da argumentação." (ATIENZA, Manuel.O Direito como Argumentação. Trad. Manuel Poirier Braz. Lisboa: Escolar, 2014, p. 335)

${ }^{288}$ MACCORMICK, Neil. Retórica e o Estado de Direito. Trad. Conrado Hübner Mendes. Rio de Janeiro: Elsevier, 2008, p. 19.

${ }^{289}$ Ao fim e ao cabo, no campo da argumentação judicial, MacCormick e Atienza parecem convergir em relação à insuficiência da dialética e da retórica para lidar com o jurídico, portanto, dentro de uma lógica pragmática, os aspectos retóricos e dialéticos da argumentação jurídica são complementares. "A conclusão que se extrai de tudo o que antecede é que se mostra inadequado considerar a argumentação jurídica sob uma perspectiva exclusivamente pragmática, quer se trate de um sistema dialéctico ou retórico. Contra a sua redução à dialéctica (...) cabe objectar que as argumentações que têm lugar em muitos contextos jurídicos, não são simplesmente de tipo dialéctico, ou não se exteriorizam dessa maneira (...) Pelo que se refere à redução de toda a argumentação jurídica a um esquema retórico basta ter em conta o facto de que a argumentação jurídica, nos seus diversos contextos, não tem como única finalidade persuadir; justificar (para um juiz ou para um dogmático) pode ser
} 
meio das teorias retóricas, procedimentais e leis. Nesse sentido, são estimados os critérios de razoabilidade, coesão, coerências narrativa e normativa da argumentação particular ao caso concreto, por um lado, bem como a universalização excepcionável (defeasible) e, por efeito, a avaliação das consequências da decisão em visão prospectiva, por outro lado. Sobre a estrutura da fundamentação das decisões, haure-se um quadro, em certa medida, silogístico, pois se baseia na subsunção do plano ôntico ao deôntico no fechamento da cadeia argumentativa.

Para o jurista escocês, "A ideia básica [de uma justificação de segunda ordem] é de um sistema jurídico como corpo coerente e coeso de normas cuja observância garante certos objetivos valorizados que podem ser buscados em conjunto de modo inteligível."290 Assim sendo, busca-se ao exame da ADI-MC 4.048 a partir dos testes de consistência/coesão, coerência e sobre as consequências (implicações jurídicas) de um argumento. ${ }^{291}$

De fato, segundo uma teoria da argumentação jurídica standard, a dimensão argumentativa do Direito somente é compreendida adequadamente ao se considerar os componentes formais, materiais e pragmáticos que existem na argumentação. A partir disso, chega-se às três principais perguntas para aqueles que enfocam o Direito como argumentação: como analisar uma argumentação jurídica, como avaliá-la e como argumentar no Direito. ${ }^{292}$

A análise consiste em várias tarefas conjuntas e interconectadas, sendo as principais a representação dos argumentos e da argumentação, mostrar-lhes as partes e examiná-las cada qual com detalhe e de acordo com a importância ao deslinde da argumentação globalmente

uma finalidade mais importante do que persuadir" (ATIENZA, Manuel.O Direito como Argumentação. Trad. Manuel Poirier Braz. Lisboa: Escolar, 2014, p. 368)

${ }^{290}$ MACCORMICK, Neil. Argumentação jurídica e Teoria do Direito. Trad. Waldéa Barcellos. São Paulo: Martins Fontes, 2006, p. 135.

291 "Por conta da natureza institucional e do contexto em que opera a prática dos julgamentos, e por conta de essa prática ser adequadamente governada, ao menos, pelo princípio da justiça formal, que ordena tratar casos iguais de maneira igual, as decisões justificadas pressupõem razões universalizáveis ou sentenças baseadas no Direito que 'cubram' a decisão em particular em questão. E apenas as sentenças adequadamente justificadas poderão a seu turno justificar essas decisões.

Uma parte necessária da justificação dessas sentenças consiste em mostrar que elas não contradizem regras jurídicas validamente estabelecidas. Uma outra parte adicional consiste em mostrar que elas estão apoiadas em princípios jurídicos estabelecidos ou em analogias próximas e razoáveis feitas a partir de regras jurídicas estabelecidas, sempre que algum princípio defensável sustente a relevância da analogia. Mas esses fundamentos de justificação, ainda que sempre necessários, não são de forma alguma sempre suficientes ou conclusivos para favorecer ou afastar uma conclusão possível em um dado caso. $\mathrm{O}$ argumento conclusivo ou definitivo de um caso, quando ele ainda permanece em aberto após esse teste de consistência e coerência, é um argumento sobre as consequências". (MACCORMICK, Neil. Retórica e o Estado de Direito. Trad. Conrado Hübner Mendes. Rio de Janeiro: Elsevier, 2008, pp. 139-140)

${ }^{292}$ ATIENZA, Manuel. Curso de Argumentación Jurídica. Madri: Trotta, 2013, p. 423. 
considerada. ${ }^{293}$ Ademais, a coesão no Direito significa a não contradição da argumentação em relação às normas estabelecidas e vinculantes. ${ }^{294}$

Por conta do expediente argumentativo desta pesquisa, a parte mais significativa da análise da consistência já se efetuou. Neste momento, explora-se comparativamente a narrativa jurisprudencial engendrada no quadro que se segue:

Quadro 2 - Narrativa jurisprudencial sobre o cabimento de ADI em face de lei orçamentária

\begin{tabular}{|l|l|}
\hline Julgados & \multicolumn{1}{|c|}{ Tese majoritária sobre a cognoscibilidade da demanda } \\
\hline ADI-QO & $\begin{array}{l}\text { É juridicamente impossível a declaração de inconstitucionalidade, pela via } \\
\text { abstrata, de destinação de recursos públicos, prevista em lei formal, mas de } \\
\text { natureza e efeitos políticos-administrativos concretos. }\end{array}$ \\
\hline ADI 2.925 & $\begin{array}{l}\text { É viável o ajuizamento de ADI contra norma orçamentária que veicule } \\
\text { autorização geral e abstrata à Presidência da República para abrir créditos } \\
\text { suplementares em termos potencialmente contraditórios à normatividade } \\
\text { constitucional. }\end{array}$ \\
\hline $\begin{array}{l}\text { ADI-MC } \\
4.048\end{array}$ & $\begin{array}{l}\text { Qualquer lei em sentido formal pode ser objeto de ADI, quando esta } \\
\text { veicular controvérsia constitucional em abstrato. }\end{array}$ \\
\hline
\end{tabular}

Fonte: Elaboração própria.

A rigor, nota-se uma ressignificação interpretativa do art. 102, I, "a", da CR/88, por parte do STF, de maneira a entender que a aferição, em específico, dos atributos da generalidade e abstração colhidos de tradicional doutrina sobre a teoria das normas só são exigidos, para fins de fiscalização abstrata de constitucionalidade, de atos normativos, excluídas as leis em sentido de formal, uma vez que a normatividade destas decorre do próprio texto constitucional.

No mérito, haure-se da perspectiva majoritária que os créditos adicionais abertos na espécie são destinados a prover despesas correntes, por sua vez não qualificáveis pela

${ }^{293}$ ATIENZA, Manuel. Curso de Argumentación Jurídica. Madri: Trotta, 2013, p. 424.

${ }^{294}$ MACCORMICK, Neil. Argumentação jurídica e Teoria do Direito. Trad. Waldéa Barcellos. São Paulo: Martins Fontes, 2006, p. 255. 
imprevisibilidade ou urgência, de modo que a via do crédito extraordinário é inviável para fazer frente aos precitados dispêndios.

Conclui-se, portanto, que há coesão nos argumentos expendidos pela corrente vencedora no acórdão analisado. Por outro lado, a coerência da argumentação se verifica desde duas dimensões, a normativa e a narrativa, no pensamento de MacCormick, segundo o qual "a noção de coerência como expressão de uma racionalidade que deve transparecer na decisão tanto de maneira interna (racionalidade entre os argumentos utilizados na decisão) quanto externa (conexão racional entre os argumentos utilizados, os fatos narrados e o ordenamento jurídico como um todo)."295

Por um lado, a coerência narrativa se refere ao fluxo temporal de eventos. Ocorre que as narrativas jurídicas replicam, no tempo analítico, eventos que se supõe ocorrido na realidade (tempo real). Assim, uma narrativa coerente significa ligações diacrônicas convincentes, a partir da combinação entre eventos e atos ordenados no curso temporal. ${ }^{296}$

Noutra banda, a coerência normativa depende de sua justificabilidade perante princípios e valores do Direito, quando tomados em conjunto, para os fins de uma vida satisfatória. Para o julgador, o argumento sobre a coerência, divide-se em duas tarefas. "Primeira, a investigação trata dos princípios ou valores que, na medida do possível, conferem sentido a um conjunto relevante de normas jurídicas - leis e precedentes lidando com o mesmo assunto no mesmo campo do Direito." ${ }^{297}$ Em segundo lugar, o juiz deve levar em conta que a coerência é essencial para a justificação, sob as luzes do lugar-comum do Estado de Direito ${ }^{298}$, que pressupõe uma concepção de racionalidade prática, clareza no Direito e previsibilidade razoável acerca da interpretação/aplicação jurídica.

Nesse sentido, da constrição da coerência se haure a possibilidade de derivação de uma decisão a partir do Direito preexistente, ao menos em um sentido fraco (weak derivability), na medida em que a coerência é uma característica ideal do sistema jurídico.

\footnotetext{
${ }^{295}$ MARTINS, Argemiro Cardoso Moreira; ROESLER, Claudia Rosane; JESUS, Ricardo Antonio Rezende de. A Noção de Coerência na Teoria da Argumentação Jurídica de Neil MacCormick: caracterização, limitações, possibilidades. In: Revista Novos Estudos Jurídicos, Itajaí-SC, v. 16, n. 2, mai./ago. 2011, pp. 207-221, p. 209.

${ }^{296}$ MACCORMICK, Neil. Retórica e o Estado de Direito. Trad. Conrado Hübner Mendes. Rio de Janeiro: Elsevier, 2008, p. 298.

${ }^{297}$ MACCORMICK, Neil. Retórica e o Estado de Direito. Trad. Conrado Hübner Mendes. Rio de Janeiro: Elsevier, 2008, p. 260.

298 "No que tange ao Estado de Direito, as pessoas podem ter, antecipadamente, razoável certeza a respeito das regras e padrões segundo os quais sua conduta será julgada, e sobre os requisitos que elas devem satisfazer para dar validade jurídica às suas transações" (MACCORMICK, Neil. Retórica e o Estado de Direito. Trad. Conrado Hübner Mendes. Rio de Janeiro: Elsevier, 2008, p. 22).
} 
Nesse ponto, o teste de coerência precitado ganha relevância em um sentido negativo, isto é, mostra-se juridicamente inadmissível que os julgadores, no exercício de sua função jurisdicional, tomem decisões, por mais desejáveis que sejam do ponto de vista moral (defensibility), as quais não estejam baseadas no Direito existente.

Ressalta-se que o teste da coerência em sentido negativo não implica na negativa do papel criativo dos juízes, justamente por não se falar em uma derivação forte (strong derivability). MacCormick entende possível o ato de desenvolver o Direito, desde que esse desenvolvimento se dê no caso a caso, ante a falta de respaldo legislativo. Isso porque "Tal abordagem caso a caso sugere a possibilidade de que um corpo de normas emerja de maneira mais densa com o decorrer do tempo."299

Por fim, importa dizer que é impossível conceber uma divisão estanque das dimensões (narrativa e normativa), porque a própria interpretação jurídica possui um caráter cronológico relevante, ou seja, as regras, princípios e doutrinas do Direito possuem sua própria história de desenvolvimento. Em suma, a coerência das normas exige narrativas jurídicas igualmente coerentes. $^{300}$

Na ADI-MC 4.048, de relatoria do Ministro Gilmar Mendes, a disputabilidade de sentidos das normas constitucionais extravasa para o campo das narrativas concorrentes acerca da possibilidade de controle das leis orçamentárias. Como já visto, a corrente vencedora argumentou estar em curso uma revisão jurisprudencial acerca da admissibilidade de ações diretas de inconstitucionalidade em face de leis de índole orçamentária, ante a contestabilidade doutrinária sobre precitada jurisprudência e a realidade de abuso iterativo de instrumentos excepcionais.

No voto do Ministro Relator, há crítica direta aos entendimentos anteriores do STF, com amparo em obras doutrinárias, assim como uma advocacia explícita pela revisão de jurisprudência, à luz de razões jurídicas tidas como melhores, o que se revelou importante para o sistema jurídico globalmente considerado, tendo em vista as possíveis funções dos precedentes emanados dessa Corte.

Conclui-se, então, que o julgamento se revelou adequado do ponto de vista da coerência narrativa, uma vez que se debateu claramente a modificação da orientação

\footnotetext{
${ }^{299}$ MACCORMICK, Neil. Retórica e o Estado de Direito. Trad. Conrado Hübner Mendes. Rio de Janeiro: Elsevier, 2008, p. 267.

${ }^{300}$ MACCORMICK, Neil. Retórica e o Estado de Direito. Trad. Conrado Hübner Mendes. Rio de Janeiro: Elsevier, 2008, p. 305.
} 
jurisprudencial e a corrente majoritária decidiu por alterá-la.

Em relação à coerência normativa, verifica-se hipótese de "desenvolvimento do Direito", porquanto sem alteração constitucional formal, assentou-se por imputar nova significação ao preceito constitucional encartado no art. 102, I, “a”, da CR/88. Realizou-se o que o Ministro Ayres Britto denominou de dois deslocamentos cognitivos ${ }^{301}$, uma vez que a corrente majoritária entendeu que a lei formal é passível de sindicabilidade pela via do controle abstrato de constitucionalidade pelo próprio desiderato do Poder Constituinte.

Ademais, a qualificação da despesa pública como imprevisível e urgente daria reforço significativo ao controle jurisdicional em abstrato dos pressupostos de edição de medida provisória pelo Chefe do Poder Executivo federal, os quais genericamente são a relevância e a urgência da regulação normativa de matéria não expressamente vedada pelo art. $62, \S 1^{\circ}$, da CR/88 $8^{302}$, incluído pela Emenda Constitucional 32/2001.

Nesses termos, reputa-se a tese vencedora coerente do ponto de vista normativo, porquanto a constrição da coerência em sentido negativo mostra-se atendida na medida em que se buscou ao "desenvolvimento do Direito", por intermédio de um problema de classificação.

Segundo MacCormick, os problemas de classificação ocorrem quando se coloca em questão alguma norma jurídica que emprega um predicado como condicionante de consequência normativa, à luz de um contexto complexo de regras de Direito legislativo ou jurisprudencial. $^{303}$

Isso porque a corrente majoritária se ampara justamente na distinção entre o predicado, o qual exige a generalidade e abstração das normas para respectiva sujeição à

\footnotetext{
${ }^{301}$ BRASIL. SUPREMO TRIBUNAL FEDERAL. Medida Cautelar na Ação Direta de Inconstitucionalidade 4.048, Plenário, Rel. Min. Gilmar Mendes, j. 14.05.2008, Publ. DJe 157, em 22.08.2008, pp. 55-192, p. 181.

${ }^{302}$ Art. 62. Em caso de relevância e urgência, o Presidente da República poderá adotar medidas provisórias, com força de lei, devendo submetê-las de imediato ao Congresso Nacional.

$\S 1^{\circ}$ É vedada a edição de medidas provisórias sobre matéria:

I - relativa a:

a) nacionalidade, cidadania, direitos políticos, partidos políticos e direito eleitoral;

b) direito penal, processual penal e processual civil;

c) organização do Poder Judiciário e do Ministério Público, a carreira e a garantia de seus membros;

d) planos plurianuais, diretrizes orçamentárias, orçamento e créditos adicionais e suplementares, ressalvado o previsto no art. $167, \S 3^{\circ}$;

II - que vise a detenção ou seqüestro de bens, de poupança popular ou qualquer outro ativo financeiro;

III - reservada a lei complementar;

IV - já disciplinada em projeto de lei aprovado pelo Congresso Nacional e pendente de sanção ou veto do Presidente da República.

${ }^{303}$ MACCORMICK, Neil. Retórica e o Estado de Direito. Trad. Conrado Hübner Mendes. Rio de Janeiro: Elsevier, 2008, p. 276.
} 
fiscalização abstrata, em relação à lei formal. É dizer: os atributos supracitados somente são esperados de "atos normativos", distintos das leis e hierarquicamente subordinados a estas, pois aí se estaria diante de um problema de competência legislativa, com a garantia de resolução de acordo com o condomínio legislativo positivado na CR/88.

Assim, os entendimentos do STF acerca da impossibilidade do ajuizamento de ADI em face de atos de efeitos concretos não se aplicam à ADI-MC 4.048, porquanto os fatores determinantes para a atração da consequência jurídica da não cognoscibilidade não se fazem presentes neste caso.

Do ponto de vista do consequencialismo jurídico, repise-se que para o jurista escocês as consequências importam na correção da decisão jurídica, porquanto deve se considerar as implicações nas condutas jurídicas dos destinatários do julgamento e o estatuto normativo determinado pela julgado, o que em nada tem a ver com a estimativa da probabilidade de mudanças comportamentais. A preocupação reside, portanto, na regra universalizável posta pelo órgão julgador, dado que se espera a ação social conforme a lei. Em suma, ganha relevo que tipos de consequências são extraídas do ato de justificação da decisão, per se.

No particular, uma vez esclarecido o "problema da classificação", mormente os entendimentos anteriores do STF não formarem precedentes vinculantes ao julgado em exame, diante da ausência de mesmo predicado, nos termos da corrente majoritária, há maior liberdade para o juiz argumentar mediante consequências.

Nesse ponto, o estabelecimento de normas de correção do julgamento converge à tomada de decisões orientadas a objetivos ${ }^{304}$, estes entendidos como valores almejados e sustentados pelo arcabouço jurídico, isto é, "Deve então contar em favor de uma decisão jurídica que ela promova ou dê apoio a um certo valor, e isso pode ser expresso em algum tipo de argumento de objetivo.",305

De acordo com a Constituição da República de 1988, como pacto constituinte, mormente em sua dimensão financeira, torna-se mais clara a adequação consequencial entre o

\footnotetext{
304 "Reconhecer isso me coloca mais ou menos no mesmo campo de Ronald Dworkin, mas não a ponto de aceitar sua distinção estipulativa entre políticas públicas e princípios. Não há valores no Direito capazes de serem considerados do tipo que sustenta uma política? O fato de os juízes perseguirem esses valores sob o signo da universalizabilidade faz, de fato, com que suas decisões tenham que ser sempre de principio. Mas isso não significa que essas decisões exijam a pré-identificação de direitos como uma rota para encontrar os princípios. Eu afirmaria, em vez disso, que os direitos são conseqüências em relação às decisões de princípios que fazemos no campo jurídico, e não que são pressupostos por elas." (MACCORMICK, Neil. Retórica e o Estado de Direito. Trad. Conrado Hübner Mendes. Rio de Janeiro: Elsevier, 2008, p. 160)

${ }^{305}$ MACCORMICK, Neil. Retórica e o Estado de Direito. Trad. Conrado Hübner Mendes. Rio de Janeiro: Elsevier, 2008, p. 160.
} 
assentado na ADI-MC 4.048 e os objetivos fundamentais do Estado democrático de Direito fundado em 1988, nos termos do art. $3^{\circ}$ da $\mathrm{CR} / 88^{306}$, porquanto uma dinâmica de freios e contrapesos robustecida pela presença do Poder Judiciário em casos de abusos constitucionais é fundamental para a valorização do planejamento e controle orçamentários como pilares do Estado Fiscal brasiliano.

Como visto no primeiro capítulo, uma concepção mais substantiva do Direito Financeiro é necessária para entender a lei orçamentária como a peça legislativa em que o Povo escolhe politicamente sobre as alocações de recursos públicos para a promoção de direitos fundamentais. Imbuído de imprescindível componente democrático, o devido processo legislativo orçamentário sai-se melhor sem o uso rotineiro de procedimentos e decisões de alocação emergencial, como é o caso da MP para abertura de crédito extraordinário. $^{307}$

A propósito, transcreve-se excerto do pensamento acadêmico de Basile Christopoulos o qual explicita com percuciência essa ideia:

\begin{abstract}
O raciocínio é simples. Toda vez que o Supremo Tribunal Federal julga a perda do objeto de uma ação que aprecia a constitucionalidade de uma lei orçamentária porque esta já esgotou o seu período de vigência, o Tribunal deve ter em mente que está condicionando a validade das leis orçamentárias à sua vigência e estimulando a formulação de leis orçamentárias inconstitucionais, pois o seu período de vigência é sempre curto. Dessa forma, quando o STF julga leis orçamentárias, talvez fosse prudente julgar sua constitucionalidade independentemente de terminado o seu período de vigência, tamanhos os efeitos danosos que essas decisões vêm provocando. Decidir assim, concordando-se ou não com a decisão, seria decidir fundado em argumentos de ordem consequencialista.

Percebe-se que nesse caso a decisão poderia ser fundamentada em princípios e regras constitucionais, como supremacia da Constituição, até mesmo na norma da democracia, tendo em vista que o procedimento democraticamente eleito para a definição de receitas e despesas é a lei orçamentária. Mas o argumento foi construído com premissas fixadas nas consequências. Essa motivação não tem fundamentos extrajurídicos e tende a ser aceita pela comunidade jurídica sem grandes percalços.
\end{abstract}

\footnotetext{
${ }^{306}$ Art. $3^{\circ}$ Constituem objetivos fundamentais da República Federativa do Brasil:

I - construir uma sociedade livre, justa e solidária;

II - garantir o desenvolvimento nacional;

III - erradicar a pobreza e a marginalização e reduzir as desigualdades sociais e regionais;

IV - promover o bem de todos, sem preconceitos de origem, raça, sexo, cor, idade e quaisquer outras formas de discriminação.

${ }^{307}$ A esse respeito, verifica-se que a doutrina constitucionalista tem realizados severas críticas à utilização da legislação governamental sob a vigência da CR/88, o que acarreta em expressivo déficit democrático em termos deliberativos: "A experiência brasileira demonstra que o Presidente da República tem feito uso abusivo das medidas provisórias para disciplinar matérias que não reclamam intervenção legislativa urgente, banalizando sua utilização e exercendo verdadeira competência legislativa ordinária paralela ao Congresso Nacional" (SOUSA, Leomar Barros Amorim. A Produção Normativa do Poder Executivo: medidas provisórias, leis delegadas e regulamentos. Brasília: Brasília Jurídica, 1999, p. 155)
} 
Em termos gerais, e especialmente na vertente da necessidade de universalização, a argumentação consequencialista pode ser fundamentada juridicamente nos princípios da Justiça e da Igualdade, pela necessidade de tratamento de casos semelhantes de forma semelhante, de maneira que a justificação dada ao caso presente possa ser utilizada no futuro em casos similares. ${ }^{308}$

Assim sendo, o argumento por consequências foi devidamente utilizado pela corrente vencedora, até mesmo pela coerência discursiva com o que colocado por alguns integrantes da ala majoritária, isto é, a posição da lei orçamentária como o segundo diploma normativo mais relevante em termos republicanos, atrás somente da própria $\mathrm{CR} / 88^{309}$.

Em síntese, ante a relativa liberdade para argumentar por consequências no caso concreto, revelou-se adequada a correlação consequencial entre a orientação do STF na ADIMC 4.048 e os objetivos eleitos pelo Poder Constituinte para serem perseguidos pela República, o que, por evidente, reflete-se na atividade financeira do Estado.

\subsection{Análise Empírico-Retórica da ADI-MC 4.048}

O objeto da presente análise discursiva é o inteiro teor do acórdão da ADI-MC 4.048, com julgamento concluído em 14 de maio de 2008 e publicado no DJe 22.08.2008, nos termos da Resolução 341/2007 do $\mathrm{STF}^{310}$. Trata-se, portanto, da composição de ementa, relatório, votos, acórdão, proclamação de resultados e outros atos processuais, os quais totalizam, na espécie, 138 laudas publicadas na imprensa oficial precitada no intervalo de páginas desde 55 a 192.

Na lógica da estratégica metodológica traçada, os indicadores representam ocorrências nas dimensões L, E e P. A análise do discurso proposta consiste no registro e contabilização

\footnotetext{
${ }^{308}$ CHRISTOPOULOS, Basile Georges Campos. Controle de Constitucionalidade de Normas Orçamentárias: o uso de argumentos consequencialistas nas decisões do Supremo Tribunal Federal. 240 f. Tese de Doutorado Faculdade de Direito, Universidade de São Paulo, São Paulo-SP, Brasil, 2014, p. 81.

309 “O SENHOR MINISTRO GILMAR MENDES (PRESIDENTE E RELATOR): (...) Disse-o muito bem o Ministro Carlos Britto, pois dificilmente vamos vislumbrar uma lei mais importante fora da Constituição do que a Lei Orçamentária.

Temos tido todas essas discussões, por exemplo, sobre direitos sociais. Como ele se realiza? O problema da omissão, como se faz esse controle? Tudo passa pelo orçamento." (BRASIL. SUPREMO TRIBUNAL FEDERAL. Medida Cautelar na Ação Direta de Inconstitucionalidade 4.048, Plenário, Rel. Min. Gilmar Mendes, j. 14.05.2008, Publ. DJe 157, em 22.08.2008, pp. 55-192, p. 185)

${ }^{310}$ BRASIL. SUPREMO TRIBUNAL FEDERAL. Resolução 341, de 16.04.2007. Institui o Diário da Justiça Eletrônico do Supremo Tribunal Federal e dá outras providências. Diário de Justiça, Seção 1, Publ. em 18.04.2007, p. 1 .
} 
das ocorrências relativas a cada dimensão do discurso jurídico, por intermédio dos indicadores já listados.

Nesse ponto, remete-se ao Anexo B da presente perquirição acadêmica em que se expõem com maior detalhamento as partes da decisão na ADI-MC 4.048, juntamente com a explicitação quantitativa dos indicadores por ocorrência nas manifestações dos Ministros integrantes do STF à época. Justifica-se esse expediente argumentativo com base na índole qualitativa da presente pesquisa, de modo que a numerosidade e a diversidade dos indicadores poderiam prejudicar a discussão dos resultados.

Na dimensão E, nota-se o maior número de ocorrência de indicadores, uma vez que a tônica de fundo do julgamento em exame é a afirmação política do Poder Judiciário, especificamente de seu órgão de cúpula, o STF, frente aos demais Poderes para controlar e influir na política fiscal da União. Nesses termos, a autoridade institucional do STF e o discurso de supremacia constitucional são retoricamente realçados.

Em relação ao E1 (Demonstração de conhecimento ou erudição), percebe-se que a corrente majoritária foi responsável pela totalidade das ocorrências, assim como esse indicador foi o de menor frequência. Uma explicação possível é a maior extensão das manifestações dessa corrente e, de alguma forma, o ônus argumentativo da revisão jurisprudencial, à luz da coerência dos precedentes.

A respeito do E2 (Amplificação do valor da Constituição ou do caso em exame), chama a atenção a superioridade quantitativa e qualitativa da corrente vencedora quanto ao ponto. Por parte dos vencedores, retoma-se a interpretação de construção retórica do locus político da Corte. Noutra banda, a falta de uso desse indicador por parte dos vencidos tem correlação à percepção unânime de falência do modelo das medidas provisórias em níveis constitucionais e democráticos. Assim, revela-se estratégia retoricamente interessante a atribuição da responsabilidade por essa crise constituinte à inação legislativa frente ao abuso da instituição jurídica pelo Poder Executivo.

As ocorrências do indicador E3 (Elogios) não podem ser atribuídas a uma das linhas argumentativas das coalizões vencedora ou vencida, mas apenas aos estilos literários idiossincráticos de cada Ministro votante, especialmente dos Ministros Carlos Britto e Celso de Mello. Ademais, o início ou a retomada da deliberação jurisdicional demandam certa referência elogiosa ao que precede, à luz de uma afirmação autoritativa da Corte, como se extrai dos votos do Ministro Relator Gilmar Mendes e da Ministra Vistora Ellen Gracie. 
Por sua vez, a alta frequência do uso do indicar E4 (Relacionamento entre Poderes) mostra um dos pontos fulcrais do julgamento e respectivo deslinde, porquanto entraram em choque duas visões acerca da configuração ideal do princípio da separação dos poderes na realidade brasileira, sobretudo no tocante à interação entre o Legislativo e o Judiciário, a partir das responsabilidades constitucionais de cada qual.

Pelo lado vencedor, haure-se o argumento de que o STF tem dever constitucional de coibir excessos normativos dos demais atores políticos em seara orçamentária. No lado minoritário, percebe-se uma ingerência por parte do STF na seara das decisões de governo, uma vez que o Tribunal não possuiria legitimidade constitucional ou capacidade institucional para fazer frente a esse encargo. Por conseguinte, o expediente argumentativo da parcela vencida leva a uma deferência ao Legislativo por parte do STF. ${ }^{311}$

Na dimensão P, observa-se a intensidade e relevância do papel das emoções ${ }^{312}$ no discurso da Corte Constitucional, inclusive em via objetiva, a qual veicula uma controvérsia constitucional em tese, e em matéria (Direito Financeiro ${ }^{313}$ ) dotada de certo tecnicismo, pois marcada por conceitos e tipos ${ }^{314}$ próprios e especializados.

Em relação ao P1 (Linguagem hiperbólica e argumento ad terrorem), constata-se que, no plano emotivo, a tese pela admissibilidade de ADI em face de lei orçamentária se fundamentou nos perigos e nas potenciais ofensas à CR/88 gerados pela ausência de controle do STF perante eventual abuso do Poder Executivo no bojo de função legiferante. Conclui-se que a aversão ao descontrole foi fator retórico relevante para a revisão jurisprudencial sobre a cognoscibilidade dessas demandas.

\footnotetext{
${ }^{311} \mathrm{Na}$ jurisprudência do STF, observa-se a articulação argumentativa em prol de diálogos institucionais no seguinte precedente: BRASIL. SUPREMO TRIBUNAL FEDERAL. Ação Direta de Inconstitucionalidade 5.105, Plenário, Rel. Min. Luiz Fux, j. 1º.10.2015, Publ. DJe 49 em 16.03.2016, pp. 1-197.

${ }^{312}$ No sentido da impossibilidade de um Direito desprovido de emoções, veja-se: NUSSBAUM, Martha C. Hiding from Humanity: disgust, shame, and the law. Princeton: Princeton University Press, 2004, pp. 5-13. Com as mesmas conclusões em relação ao Direito brasileiro e ao STF: "concluímos que é impossível compreender a estruturação do direito sem estudar as emoções, pois estas são causas para a elaboração de leis, para ingressar com uma demanda em juízo e para solucionar uma controvérsia jurídica. A apatheia estoica é um modelo inadequado para explicar o direito, porque o nosso ordenamento jurídico valoriza e protege aqueles bens que os estoicos denominariam de indiferentes. Ademais, as nossas emoções são respostas aos mais diversos tipos de danos que a nossa vulnerável constituição físico-psíquica pode apresentar, sendo que o direito leva isso em consideração quando socialmente relevante." (SANTOS, Marcelo Fernandes Pires dos. Retórica, Teoria da Argumentação e Pathos: o problema das emoções no discurso jurídico. 151 f. Dissertação de Mestrado, Faculdade de Direito, Universidade de Brasília, Brasília, Brasil, 2015)

${ }^{313}$ CORTI, Horacio Guillermo. Derecho Constitucional Presupuestario. 2 ed. Buenos Aires: AbeledoPerrot, 2011, p. XXVII. Acerca do ensino das "Ciências das Finanças" nas Faculdades brasileiras, veja-se: BALLEIRO, Aliomar. Uma Introdução à Ciência das Finanças. 17 ed. Rio de Janeiro: Forense, 2010, pp. 12-13.

${ }^{314}$ Cf. DERZI, Misabel de Abreu Machado. Tipo ou conceito no Direito Tributário? In: Revista da Faculdade de Direito da UFMG, Belo Horizonte, n. 30/31, 1987/1988, pp. 213-260.
} 
No que tange aos indicadores P2 (Ênfase e pergunta retórica) e P4 (Apartes divergentes), uma análise conjunta é possível na medida em que revelam baixo desempenho deliberativo do STF na espécie, notadamente na fase decisional, ante a ausência de troca argumentativa entre os juízes. ${ }^{315}$ Observa-se, por conseguinte, uma baixa predisposição ao diálogo, ainda que na divergência. ${ }^{316}$ No entanto, impende asseverar que essa constatação não foge do padrão institucional do Tribunal, como se depreende de pesquisa empírica qualitativa realizada por Virgílio Afonso da Silva consistente em entrevistas com os Ministros do STF em atividade e aposentados acerca da prática do voto vencido: "Tanto os atuais quanto os antigos ministros não parecem identificar grandes problemas em relação à forma atual de publicação de votos divergentes ou concorrentes. Tampouco veem grandes diferenças entre votos divergentes e vencidos no STF." 317

Acerca do P3 (remissão à opinião pública ou publicada), constata-se ser esse o indicador de menor frequência na análise proposta, assim como fora utilizado em sua primazia pelo Ministro Relator do caso, especialmente como artifício para gerar empatia pública à tese de revisão jurisprudencial. Algumas inferências são possíveis, sobretudo duas ideias contrapostas à categoria de "sociedade aberta de intérpretes constitucionais" 318 : a pressuposição de certo "exclusivismo judicial" 319 acerca da interpretação constitucional; e a

\footnotetext{
315 "Com essas duas distinções esclarecidas, uma corte genuinamente deliberativa, de maneira curta e direta, é aquela que maximiza o raio de argumentos dos interlocutores ao promover contestação pública na fase prédecisional; que estimula os juízes numa prática sincera de interação colegiada na fase decisional; e que redige uma decisão deliberativa na fase pós decisional. Em outras palavras, quando alguém se propõe a verificar se uma corte constitucional está cumprindo com seus deveres deliberativos, deve voltar sua atenção para as interações escrita e face-a-face entre juízes e interlocutores, em seguida para a troca argumentativa entre juízes e, finalmente, para a decisão escrita entregue ao público.” (MENDES, Conrado Hübner. O Projeto de uma Corte Deliberativa. In: VOJVODIC, Adriana et al (org.). Jurisdição Constitucional no Brasil. São Paulo: Malheiros, 2012, p. 60)

316 "A partir dessa contraposição, voto divergente seria caracterizado não apenas por não seguir a decisão majoritária, mas também por apontar eventuais problemas nessa decisão vencedora, por tentar estabelecer um diálogo com ela. Já o voto que não segue a decisão majoritária, mas com ela não dialoga, seria então caracterizado como mero voto vencido" (SILVA, Virgílio Afonso da. De Quem Divergem os Divergentes: os votos vencidos no Supremo Tribunal Federal. In: Direito, Estado e Sociedade, Rio de Janeiro, n. 47, jul./dez. 2015 , pp. 205-225, p. 217)

${ }^{317}$ SILVA, Virgílio Afonso da. De Quem Divergem os Divergentes: os votos vencidos no Supremo Tribunal Federal. In: Direito, Estado e Sociedade, Rio de Janeiro, n. 47, jul./dez. 2015, pp. 205-225, p. 224.

${ }^{318}$ Cf. HÄBERLE, Peter. Hermenêutica Constitucional: a sociedade aberta dos intérpretes da Constituição contribuição para a interpretação pluralista e procedimental da constituição. Trad. Gilmar Ferreira Mendes. Porto Alegre: Sergio Antonio Fabris, 1997.

319 "One form of legislative constitutionalism - the more modest version - claims that the legislature has a role to play in constitutional interpretation. This branch of legislative constitutionalism denies the judiciary a monopoly on constitutional interpretation; it simply rejects judicial exclusivity withou questioning judicial supremacy and, as such, seems unobjectable. It derives from a single recognition of the universalismo $f$ the Constitution - that it is binding on us all." (FISS, Owen. Between Supremacy and Exclusivity. In: BAUMAN, Richard W.; KAHANA, Tsvi (org.). The Least Examined Branch: the role of legislature in the Constitutional State. Nova York: Cambridge University Press, 2006, pp. 459-460)
} 
ausência de uma intenção, ao menos retórica, de promover uma jurisdição constitucional marcada por uma atuação dialógica e eminentemente popular. ${ }^{320}$

Em relação à dimensão $\mathrm{L}$, a descoberta mais relevante é a baixa intensidade e significância dos indicadores propostos, o que corrobora a premissa posta em introito acerca da exclusão do âmbito de conhecimento jurídico ${ }^{321}$ de parcela relevante do conceito analítico de Direito Financeiro ${ }^{322}$, a despeito de sua positivação minuciosa em nível constitucional, inclusive em Capítulo próprio tachado "Das Finanças Públicas".

Nesses termos, a respeito do indicador L1 (argumentos baseados nas fontes do Direito), faz sentido a diferenciação proposta por Katharina Sobota em relação à autoreferência (pseudo e cripto), uma vez que o presente indicador seria o cerne de uma etiologia

\footnotetext{
${ }^{320}$ Contra essa exclusão do Povo da interpretação constitucional: "The courts are educators because they engage in a complex interaction with the public and legislators over questions about the Constitucion's meaning. The thinness of the Constituion outside the courts leaves so much open for discussion that similar interactions would occur among legislators, and between legislators and their constituents. The courts are surely not the only institutions that educate us about our fundamental rights, and we might get a decente education even if the courts played a much smaller role." (TUSHNET, Mark. Taking the Constitution Away From The Courts. New Jersey: Princeton, 1999, p. 168). No Direito brasileiro e referenciado ao STF, veja-se: "O sentido da Constituição deve ser construído e definido coletivamente entre o povo e as instituições de sua sociedade. Nesse sentido, é certo que o Poder Judiciário tem um papel fundamental na definição da interpretação constitucional e da aplicação da constituição, mas a efetivação da constituição não pode viver apenas da interpretação que os juízes e as cortes constitucionais fazem dela (...) Quando o Supremo Tribunal Federal exerce sua competência, também está ele a dizer de que forma compreende a Constituição e, portanto, como ela deve ser concretizada. No entanto, suas interpretações e decisões sobre a Constituição não são e não podem nunca se pretender absolutas, sob pena de excluírem-se os demais Poderes, instituições e o próprio povo na tarefa de definir os conteúdos e limites da nossa Constituição. As decisões dos juízes e das cortes são importantes para garantir que os conflitos e as divergências terão uma resposta, mas o Poder Judiciário deve ser consciente de que suas respostas definitivas (nos casos em tese ou nos casos concretos) são sempre provisórias, temporárias, precárias, pois estão sujeitas à revisão e à superação. São decisões que põem fim a um processo judicial, mas não a um processo de debate público e democrático." (GODOY, Miguel Gualano de. Devolver a Constituição ao Povo: crítica à supremacia judicial e diálogos interinstitucionais. 267 f. Tese de doutorado - Faculdade de Direito, Universidade Federal do Paraná, Paraná, 2015, pp. 104-105)

${ }^{321}$ "Se ve la lógica de la situación, em la cual se escucha al menos uma reverberación del aspecto negativo de la razón de Estado: aquello que está fuera de control se hace de acuerdo con la disceción del poder. Dicho crudamente esto sinifica que la Caja del Estado puede disponerse de acuerdo com el parecer de los governantes. Luego, si uma decisión financeira, así el presupuesto, no puedo ser objeto de control de constitucionalidade, también disminuyen los incentivos práctics para examinar su régimen constitucional. Exclusión del control, exclusión de la juridicidade, exclusión del ámbito del conocimiento.

Por certo, no es que dicho examen constitucional diretamente no existiese. Sin duda que sí, pero si se recorre la bibliografia que mantuvo su interés por el presupuesto, tanto la específica como los textos generales de derecho constitucional, aquello que se encuentra es, basicamente, uma referencia al procedimiento presupuestario, sin ninguna consideración de mayor envergadura jurídica su función y significación constitucional." (CORTI, Horacio Guillermo. Derecho Constitucional Presupuestario. 2 ed. Buenos Aires: Abeledo-Perrot, 2011, pp. XXVI-XXVII)

322 "Em sendo assim, pode-se fazer a exclusão do que não está afeto ao direito financeiro: a) os tributos; b) o câmbio; e c) moeda.

O que está incluído no direito financeiro: a) receitas não tributárias; b) as despesas; c) o orçamento; d) o controle orçamentário que engloba os Tribunais de Contas; e) a dívida pública; e f) a responsabilidade fiscal." (OLIVEIRA, Regis Fernandes de. Direito Financeiro: conceito, autonomia e fontes. In: MARTINS, Ives Gandra da Silva; MENDES, Gilmar Ferreira; NASCIMENTO, Carlos Valder do. Tratado de Direito Financeiro. v. 1. São Paulo: Saraiva, 2013, p. 11)
} 
da decisão judicial, ao passo que pela análise retórica dos discursos nota-se maior importância discursiva dada ao ethos da Corte e aos elementos passionais. Em suma, torna-se difícil sustentar a presença de uma racionalidade jurídica de forma exigente e universal, diante do realce de dinâmicas de poder em detrimento de recursos técnicos ao arcabouço jurídicofinanceiro. $^{323}$

No tocante ao L2 (argumentos hermenêuticos), verifica-se um esforço apenas nos votos do Ministro Relator e da Ministra Vistora a se conformarem pela constrição da autoreferência, uma vez que se busca pelo recurso ao indicador referido permitir a posteriori um esforço de descrição retórica da gênese da decisão pela doutrina e jurisprudência. No mais, são salientes as constrições da latência e do decoro na espécie, uma vez que para a primeira o Direito é forçado a ocultar os reais mecanismos de sua produção para viabilizar a criação por processos linguísticos de uma "segunda realidade", enquanto para a segunda perspectiva constritiva o discurso judicial deve ser produzido de uma maneira vista como decorosa ou apropriada pela audiência.

O indicador L3 (argumentos do cotidiano) foi utilizado somente pela corrente vencedora para expressar demonstrativamente o abuso na forma de utilização de MPs pela Presidência da República em período posterior à redemocratização. Logo, por recursos estatísticos, busca-se ressaltar a imperatividade do controle de constitucionalidade de leis orçamentárias.

A respeito do L4 (operações de lógica), trata-se de uma estratégia discursiva utilizada especialmente pelo Ministro Relator com o fito de sustentar a logicalidade da modificação jurisprudencial em contraposição à orientação pretoriana anterior.

\subsection{A Justiciabilidade em Abstrato da Abertura de Créditos Extraordinários}

Na presente seção, busca-se discutir conclusivamente acerca da possibilidade de juízos de constitucionalidade em via de processo objetivo sobre decisões orçamentárias de abertura

\footnotetext{
${ }^{323}$ A título ilustrativo, veja-se a seguinte manifestação do Ministro Cezar Peluso: "Não é o Supremo Tribunal que deva dizer à Presidência da República ou ao Congresso Nacional se podem, ou não, gastar, mediante créditos extraordinários, mediante crédito suplementar ou mediante crédito que seja lá que título tenha, do ponto de vista orçamentário. Isso é atividade típica de governo. É o Governo que decide sobre isso. E, se decide mal, responde perante as outras instâncias" (BRASIL. SUPREMO TRIBUNAL FEDERAL. Medida Cautelar na Ação Direta de Inconstitucionalidade 4.048, Plenário, Rel. Min. Gilmar Mendes, j. 14.05.2008, Publ. DJe 157, em 22.08.2008, pp. 55-192, p. 120)
} 
de crédito extraordinário, mediante MP. Como posto ao início, esse debate, por si só monográfico, terá o enfoque em duas questões: o cabimento de jurisdição constitucional na modalidade abstrata na hipótese e a competência do Poder Judiciário para avaliar a ocorrência dos requisitos de edição de MP.

Primeiro, retoma-se a questão da conveniência e possibilidade de uma Corte Constitucional em uma democracia, o que se reflete na adequação democrática do controle de constitucionalidade, sobretudo em relação à tutela de direitos fundamentais e aos impasses institucionais entre os Poderes, como é o caso da decisão orçamental. Assim, os pressupostos éticos e teóricos das teorias da argumentação jurídica respaldam a justiciabilidade das questões relativas ao orçamento público.

Por um lado, a racionalidade prática aponta para a necessidade de controle do Juiz Constitucional perante hipóteses de inexecução orçamentária reiterada e em violação à normatividade constitucional, à luz do depreendido da tecnologia jurídica ínsita ao Direito Financeiro. Isso porque os ideais de respeito aos procedimentos constitucionais e às decisões democráticas respaldam a fundamentação de um juízo ético calcado em um objetivismo moral mínimo, com o fito de controle, transparência, planejamento e responsabilização da dinâmica orçamentária.

Por outro lado, em que pese a adoção por parte da retórica moderna de certo ceticismo, deve-se ter em conta o relacionamento entre democracia e retórica, viabilizado pela possibilidade de interrupção de uma cadeia argumentativa por parte de uma corte constitucional, em razão de sua própria autoridade, funcionalizando, ao fim e ao cabo, a própria ambiência democrática.

É dizer que o intuito conciliatório e propositivo deve pautar a atuação do STF nesse espaço dialógico da esfera pública. Enfim, sem lógica de adversariedade ou palavras definitivas, torna-se cabível, em jurisdição constitucional, estabilizar as expectativas sociais dos mais diversos setores sociais, por meio do encerramento de uma cadeia argumentativa, dada a constrição da inafastabilidade jurisdicional, sendo aquela passível de retomada por meio de processos democráticos e constitucionais.

Por sua vez, em relação à competência do STF para julgar a ocorrência dos requisitos autorizativos para a edição de MP, verifica-se, igualmente, um alargamento das hipóteses de controle desses pressupostos por parte do Estado-Juiz.

Inicialmente, observa-se no julgamento da ADI-MC 1.717, de relatoria do Ministro 
Sydney Sanches ${ }^{324}$, que o STF somente teria competência para avaliar a falta dos requisitos da relevância e da urgência de MP, quando caracterizada objetivamente. Nesse sentido, nos demais casos, a discricionariedade seria a tônica da dinâmica institucional, isto é, "quando dependa de uma avaliação subjetiva, estritamente política, mediante critérios de oportunidade e conveniência, esta confiada aos Poderes Executivo e Legislativo, que têm melhores condições que o Judiciário para uma conclusão a respeito." ${ }^{325}$ Outro exemplo da diretriz jurisprudencial referente à "evidência objetiva da ausência de requisitos" se deu com o julgamento da ADI-MC 2.527, de relatoria da Ministra Ellen Gracie, para quem "Esta Suprema Corte somente admite o exame jurisdicional do mérito dos requisitos de relevância e urgência na edição de medida provisória em casos excepcionalíssimos, em que a ausência desses pressupostos seja evidente., ${ }^{326}$

Em linha concorrente, o Tribunal Pleno do STF já proferiu julgamentos em que a sindicabilidade jurisdicional passou a abarcar os casos nos quais constatados o "excesso do poder" ${ }^{327}$ de legislar por parte do Poder Executivo, ainda que nos estreitos limites do princípio da separação dos poderes. ${ }^{328}$

No mais, precipuamente após as reformas constitucionais em sentido formal promovidas pela Emenda Constitucional observa-se que essa segunda corrente jurisprudencial tem se verticalizado, seja nas críticas relativas à utilização abusiva de medidas provisórias pela PR, seja na possibilidade do Estado judicante impedir o exercício dessa competência extraordinária, o que se converteria em "verdadeiro cesarismo governamental", nas palavras

\footnotetext{
${ }^{324}$ BRASIL. SUPREMO TRIBUNAL FEDERAL. Medida Cautelar na Ação Direta de Inconstitucionalidade 1.717, Plenário, Rel. Min. Sydney Sanches, j. 22.09.1999, Publ. DJ 25.02.2000, pp. 63-115.

${ }^{325}$ Excerto da ementa do referido julgado: "3. No que concerne à alegada falta dos requisitos da relevância e da urgência da Medida Provisória (que deu origem à Lei em questão), exigidos no art. 62 da Constituição, o Supremo Tribunal Federal somente a tem por caracterizada quando neste objetivamente evidenciada. E não quando dependa de uma avaliação subjetiva, estritamente política, mediante critérios de oportunidade e conveniência, esta confiada aos Poderes Executivo e Legislativo, que têm melhores condições que o Judiciário para uma conclusão a respeito." (BRASIL. SUPREMO TRIBUNAL FEDERAL. Medida Cautelar na Ação Direta de Inconstitucionalidade 1.717, Plenário, Rel. Min. Sydney Sanches, j. 22.09.1999, Publ. DJ 25.02.2000, pp. 63-115, pp. 63-64).

${ }^{326}$ BRASIL. SUPREMO TRIBUNAL FEDERAL. Medida Cautelar na Ação Direta de Inconstitucionalidade 2.527, Plenário, Rel. Min. Ellen Gracie, j. 16.08.2007, Publ. DJe 147 em 23.11.2007, pp. 107-178.

${ }^{327}$ Percebe-se que essa tese já era ventilada na ADI-MC 162, de relatoria do Ministro Moreira Alves, embora inaplicada. Reproduz-se excerto da ementa desse julgado: "Os conceitos de relevância e de urgência a que se refere o artigo 62 da Constituição, como pressupostos para a edição de Medidas Provisórias, decorrem, em princípio, do Juízo discricionário de oportunidade e de valor do Presidente da República, mas admitem o controle judiciário quando ao excesso do poder de legislar, o que, no caso, não se evidencia de pronto." (BRASIL. SUPREMO TRIBUNAL FEDERAL. Medida Cautelar na Ação Direta de Inconstitucionalidade 162, Plenário, Rel. Min. Moreira Alves, j. 14.12.1989, Publ. DJ 19.09.1997, pp. 1-48, p. 1)

${ }^{328}$ BRASIL. SUPREMO TRIBUNAL FEDERAL. Ação Direta de Inconstitucionalidade 1.647, Plenário, Rel. Min. Carlos Velloso, j. 02.12.1998, Publ. DJ 26.03.1999, pp. 93-125.
} 
do Ministro Celso de Mello. ${ }^{329}$ De fato, a competência repressiva do STF exsurgiria da própria estrutura constitucional que disciplina as medidas provisórias, porquanto os predicados da "urgência", "relevância" e "despesas imprevisíveis e emergenciais" se traduzem em condicionantes jurídicos e legitimadores para o exercício de competência normativa primária por parte do Poder Executivo federal, revelando a índole constitucional da controvérsia. ${ }^{330}$

Acompanha-se, ainda, o raciocínio desenvolvido pelo Ministro Celso de Mello na ADI-MC em exame, segundo o qual os pressupostos de edição de medida provisória se submetem a sucessivas ordens de controle avaliativo entre os Poderes da União. ${ }^{331}$

\begin{abstract}
${ }^{329}$ BRASIL. SUPREMO TRIBUNAL FEDERAL. Medida Cautelar na Ação Direta de Inconstitucionalidade 4.048, Plenário, Rel. Min. Gilmar Mendes, j. 14.05.2008, Publ. DJe 157, em 22.08.2008, pp. 55-192, p. 168.

${ }^{330}$ Acerca da verticalização referida, transcreve-se excerto esclarecedor, ainda que longo, da ementa da ADI-MC 2.213, de relatoria do Ministro Celso de Mello: "POSSIBILIDADE DE CONTROLE JURISDICIONAL DOS PRESSUPOSTOS CONSTITUCIONAIS (URGÊNCIA E RELEVÂNCIA) QUE CONDICIONAM A EDIÇÃO DE MEDIDAS PROVISÓRIAS. - A edição de medidas provisórias, pelo Presidente da República, para legitimar-se juridicamente, depende, dentre outros requisitos, da estrita observância dos pressupostos constitucionais da urgência e da relevância (CF, art. 62, 'caput'). - Os pressupostos da urgência e da relevância, embora conceitos jurídicos relativamente indeterminados e fluidos, mesmo expondo-se, inicialmente, à avaliação discricionária do Presidente da República, estão sujeitos, ainda que excepcionalmente, ao controle do Poder Judiciário, porque compõem a própria estrutura constitucional que disciplina as medidas provisórias, qualificando-se como requisitos legitimadores e juridicamente condicionantes do exercício, pelo Chefe do Poder Executivo, da competência normativa primária que lhe foi outorgada, extraordinariamente, pela Constituição da República. Doutrina. Precedentes. - A possibilidade de controle jurisdicional, mesmo sendo excepcional, apóiase na necessidade de impedir que o Presidente da República, ao editar medidas provisórias, incida em excesso de poder ou em situação de manifesto abuso institucional, pois o sistema de limitação de poderes não permite que práticas governamentais abusivas venham a prevalecer sobre os postulados constitucionais que informam a concepção democrática de Poder e de Estado, especialmente naquelas hipóteses em que se registrar o exercício anômalo e arbitrário das funções estatais. UTILIZAÇ̃̃O ABUSIVA DE MEDIDAS PROVISÓRIAS INADMISSIBILIDADE - PRINCÍPIO DA SEPARAÇÃO DOS PODERES - COMPETÊNCIA EXTRAORDINÁRIA DO PRESIDENTE DA REPÚBLICA. - A crescente apropriação institucional do poder de legislar, por parte dos sucessivos Presidentes da República, tem despertado graves preocupações de ordem jurídica, em razão do fato de a utilização excessiva das medidas provisórias causar profundas distorções que se projetam no plano das relações políticas entre os Poderes Executivo e Legislativo. - Nada pode justificar a utilização abusiva de medidas provisórias, sob pena de o Executivo - quando ausentes razões constitucionais de urgência, necessidade e relevância material -, investir-se, ilegitimamente, na mais relevante função institucional que pertence ao Congresso Nacional, vindo a converter-se, no âmbito da comunidade estatal, em instância hegemônica de poder, afetando, desse modo, com grave prejuízo para o regime das liberdades públicas e sérios reflexos sobre o sistema de 'checks and balances', a relação de equilíbrio que necessariamente deve existir entre os Poderes da República. - Cabe, ao Poder Judiciário, no desempenho das funções que lhe são inerentes, impedir que o exercício compulsivo da competência extraordinária de editar medida provisória culmine por introduzir, no processo institucional brasileiro, em matéria legislativa, verdadeiro cesarismo governamental, provocando, assim, graves distorções no modelo político e gerando sérias disfunções comprometedoras da integridade do princípio constitucional da separação de poderes. - Configuração, na espécie, dos pressupostos constitucionais legitimadores das medidas provisórias ora impugnadas. Conseqüente reconhecimento da constitucionalidade formal dos atos presidenciais em questão." (BRASIL. SUPREMO TRIBUNAL FEDERAL. Medida Cautelar na Ação Direta de Inconstitucionalidade 2.213, Plenário, Rel. Min. Celso de Mello, j. 04.04.2002, Publ. DJ
\end{abstract} 23.04.2004, pp. 296-466, pp. 296-298)

331 “O SENHOR MINISTRO CELSO DE MELLO: Há ordens sucessivas de avaliação de tais pressupostos. Quem os avalia, inicialmente, é o Presidente da República, quando da edição da medida provisória. Depois, o Congresso Nacional , por ocasião do exame e votação desse ato presidencial com força de lei. Finalmente, 
Outro fato digno de nota é a conversão da MP 405/2007 na Lei 11.658/08, sem alteração substancial no conteúdo e com a realização de aditamento à inicial, logo a não prejudicialidade do objeto se deu de maneira condizente à jurisprudência do STF. ${ }^{332}$ Igualmente, é entendimento iterativo do STF que a lei de conversão não convalida os vícios formais eventualmente presentes na MP, que poderão ser objeto de análise do Tribunal, no âmbito do controle de constitucionalidade. ${ }^{333}$

Tema também relevante abordado ao longo dos votos, a ser retomado no capítulo subsequente, é a possibilidade do julgamento de processo objetivo contra ato normativo que possua sua eficácia exaurida, uma vez que se coloca em questão a efetividade da jurisdição constitucional face aos desafios referentes à defesa dos direitos fundamentais. Nesse sentido, há uma tensão entre a utilidade do provimento jurisdicional em abstrato contra ato exaurido no mundo jurídico e a indenidade de lei marcada pelo vício da inconstitucionalidade, pela característica própria das leis orçamentárias que é a transitoriedade.

Por fim, verifica-se que a divisão funcional dos Poderes da União em matéria orçamentária revelou-se o tema de maior discordância entre os Ministros do STF, como se depreendeu da análise dos discursas levada a efeito supra. Aliás, ressalta-se que as disfuncionalidades das práticas pertinentes aos créditos extraordinários serão o objeto precípuo do próximo capítulo.

quando provocado, o Judiciário, que dispõe de plena competência para efetuar esse controle, eis que os requisitos da urgência e da relevância qualificam-se como fatores constitucionais de legitimação da edição das medidas provisórias." (BRASIL. SUPREMO TRIBUNAL FEDERAL. Medida Cautelar na Ação Direta de Inconstitucionalidade 4.048, Plenário, Rel. Min. Gilmar Mendes, j. 14.05.2008, Publ. DJe 157, em 22.08.2008, pp. 55-192, p. 186)

332 "Ação direta de inconstitucionalidade e reedição de medidas provisórias: evolução da jurisprudência: aditamento da petição inicial: pressuposto de identidade substancial das normas. A possibilidade do aditamento da ação direta de inconstitucionalidade de modo a que continue, contra a medida provisória reeditada, o processo instaurado contra a sua edição original, pressupõe necessariamente a identidade substancial de ambas: se a norma reeditada é, não apenas formal, mas também substancialmente distinta da originalmente impugnada, impõe-se a propositura de nova ação direta.” (BRASIL. SUPREMO TRIBUNAL FEDERAL. Questão de Ordem em Ação Direta de Inconstitucionalidade 1.753, Plenário, Rel. Min. Sepúlveda Pertence, j. em 17.09.1998, Publ. DJ 23.10.1998, pp. 36-44)

${ }^{333}$ BRASIL. SUPREMO TRIBUNAL FEDERAL. Questão de Ordem na Medida Cautelar na Ação Direta de Inconstitucionalidade 3.090, Plenário, Rel. Min. Gilmar Mendes, j. em 11.10.2006, Publ. DJe 131 em 26.10.2007. 


\section{O ORÇAMENTO PÚblico E A ABERTURA DE CRÉditos EXTRAORDINÁRIOS POR MEDIDA PROVISÓRIA}

A partir da decisão levada a efeito na ADI-MC 4.048, pretende-se averiguar empiricamente o relacionamento entre os Poderes da União no período compreendido entre os exercícios financeiros de 2008 a 2015, notadamente no que tange à abertura de créditos adicionais extraordinários por meio de MP, nos termos do art. 167, §3º da CR/88.

Parte-se da dimensão empírica da dogmática jurídica, de modo a extrair padrões decisórios nas perspectivas institucionais e cognitivas relacionadas ao fenômeno financeiro estudado em seus aspectos constitucionais, com vistas a elucidar a temática e os problemas desta investigação científica.

Nesse sentido, o expediente adotado é o estudo descritivo dos desempenhos institucionais e deliberativos da $\mathrm{PR}$, do $\mathrm{CN}$ e do $\mathrm{STF}$ em relação ao tema dos créditos extraordinários. Posteriormente, busca-se lançar luzes ao estado da arte delineado, a partir de referenciais teóricos da doutrina constitucionalista e da ciência política, de maneira a aportar elementos teoréticos ao diagnóstico proposto.

Após isso, na perspectiva prático-normativa posta em introito, o fenômeno financeiro será tratado como fato social total ${ }^{334}$, por isso imbricado na dinâmica social e passível de múltiplas referências. Assim, diante das perspectivas jurídicas, morais, religiosas, econômicas e estéticas passíveis de análise, opta-se por restar adstrito à chave analítica constitucional atinente à prática institucional dos créditos extraordinários.

\subsection{A Separação dos Poderes e a Emergência Constitucional}

Na qualidade de elemento essencial do constitucionalismo, a separação dos poderes consiste em artefato para o controle do poder pelo poder, uma vez que o pluralismo político apresenta como contributo ao combate à tirania a dispersão da soberania, impedindo que alguma facção política monopolize a esfera política para representar-se como a voz do Povo soberano. Noutras palavras: o pluralismo busca a um sistema democrático em que a ninguém

\footnotetext{
${ }^{334}$ MAUSS, Marcel. Ensaio sobre a Dádiva. Lisboa: 70, 1988, passim.
} 
seja permitido falar em nome da totalidade do Povo. ${ }^{335}$

Assim, segundo Carlos Santiago Nino, a vontade popular encontra-se distendida ao longo de diversas dimensões temporais, espaciais e funcionais. Temporalmente essa vontade expressa-se por meio da interpretação constitucional haurida de conjunto normativo produzido em momento constituinte e de maiorias hodiernas na forma de eleições e do processo legislativo. Em termos espaciais, a organização territorial do Estado é expressão da dispersão da soberania, notadamente na forma do federalismo. Em relação à dimensão funcional, tem-se que o poder soberano espalha-se em diferentes órgãos, entidades e agentes políticos, que devem reagir positivamente ou negativamente aos mesmos fatos políticos. Desse modo, nenhum grupo de interesse majoritário ou minoritário possui condições de controlar todo loci de poder, quando há tantos atores suficientemente separados uns dos outros. $^{336}$

Em perspectiva diferente, mas correlata, Karl Loewenstein entende os controles do poder político nos eixos vertical e horizontal, sendo este subpartido em controles interno e externo. Nesse âmbito, o controle vertical se traduz nas expressões do federalismo, dos direitos fundamentais e do pluralismo, conquanto o horizontal, na perspectiva do controle externo, expressa-se de quatro formas: o Parlamento em face do Governo, desde o controle das nomeações do Executivo à possibilidade de impeachment; o Governo em face do Parlamento, sobretudo em decorrência da atividade normativa do Poder Executivo; os Tribunais diante do Governo e do Parlamento, à luz do controle judicial dos atos administrativos e normativos; e o eleitorado frente ao Governo e ao Parlamento, por intermédio do exercício dos instrumentos democráticos diretos e representativos. ${ }^{337}$

$\mathrm{Na}$ tentativa de iluminar as maneiras complexas pelas quais arranjos institucionais prestam-se a expressar concretamente ideais, Bruce Ackerman escora-se em três ideias legitimadoras para fins de responder a seguinte pergunta: separação dos poderes em prol do quê? O primeiro ideal é a democracia, isto é, a separação dos poderes pode servir ao projeto de autogoverno popular. Em seguida, há a competência profissional, uma vez que leis democráticas são meramente simbólicas sem tribunais e burocracias aptas a implementá-las de maneira imparcial. Por fim, a proteção e a promoção dos direitos fundamentais são o

\footnotetext{
${ }^{335}$ NINO, Carlos Santiago. La Constitución de la Democracia Deliberativa. Trad. Roberto P. Saba. Barcelona: Gedisa, 1997, pp. 228-229.

${ }_{336}$ NINO, Carlos Santiago. La Constitución de la Democracia Deliberativa. Trad. Roberto P. Saba. Barcelona: Gedisa, 1997, pp. 228-229.

${ }^{337}$ LOEWENSTEIN, Karl. Teoría de la Constitución. Trad. Alfredo Gallego Anabitarte. 2 ed. Barcelona: Ariel, 1976, pp. 232-468.
} 
terceiro ideal inspirador da separação dos poderes, notadamente como salvaguarda contra a tirania. $^{338}$

Por outro lado, a divisão funcional do poder em demasia também apresenta suas desvantagens. Uma delas é a debilitação do valor epistêmico da democracia, tendo em vista que não ocorre uma conexão direta entre as conclusões de um diálogo democrático e uma justificação para atuar de acordo com a diretriz conclusiva. ${ }^{339}$

Há, ainda, apreciável risco de bloqueio mútuo entre os detentores do poder, caracterizado por "becos sem saída" (deadlocks) institucionais impassíveis de resolução por meios constitucionais. Sendo assim, a dispersão do poder leva à inviabilização do exercício constitucional do poder. A ausência de colaboração na formação da vontade estatal termina por gerar uma crise, por sua vez resolvida mediante uma ruptura constitucional na qual se recorre à ilegalidade, força ou revolução. ${ }^{340}$

Ademais, há um sensível déficit democrático, pois a democracia torna-se consolidada, quando o compliance (agir de acordo com o marco institucional) constitui o ponto de equilíbrio das estratégias descentralizadas de todas as forças políticas relevantes. Em termos menos técnicos, uma democracia revela-se estabelecida na hipótese de todas as forças políticas considerarem melhor submeterem seus interesses e valores a uma dinâmica incerta entre as instituições. Logo, independente do resultado, o agir político é orientado dentro do marco institucional em detrimento da tentativa de subverter a democracia para fins de implantação de um projeto político hegemônico. ${ }^{341}$

Nessa seara, para além de uma visão formalista do relacionamento entre os Poderes ${ }^{342}$,

\footnotetext{
${ }^{338}$ ACKERMAN, Bruce. The New Separation of Powers. In: Harvard Law Review, Cambridge-EUA, v. 113, n. 3, jan. 2000, pp. 633-729, pp. 639-640.

${ }^{339}$ NINO, Carlos Santiago. La Constitución de la Democracia Deliberativa. Trad. Roberto P. Saba. Barcelona: Gedisa, 1997, p. 229.

340 "Para evitar que el processo politico se detenga, uno de los detentadores del poder impone su supremacy sobre los otros, quizá porque cra que cuenta con el apoyo del pueblo o con el aparato policíaco y military. Ampliando arbitratiamente sus competencias constitucionales o por un gole de Estado extraconstitucional, el detentador del orden tomará el mando sobre la maquinaria estatal bloqueada. En algunos Estados se han producido serias crisis constitucionales porque la constitución no se había preocupado de solucionar estos bloqueos entre los detentadores del poder, del mismo rango." (LOEWENSTEIN, Karl. Teoría de la Constitución. Trad. Alfredo Gallego Anabitarte. 2 ed. Barcelona: Ariel, 1976, p. 347)

${ }^{341}$ PRZEWORSKI, Adam. Democracy and the Market: political and economic reforms in Eastern Europe and Latin America. Nova York: Cambridge University Press, 1991, p. 26.

${ }^{342}$ Para uma crítica da formalização excessiva do direito constitucional, processo que culmina na exclusão da Política da Constituição, vejam-se: BERCOVICI, Gilberto. Constituição e Política: uma relação difícil. In: Lua Nova, São Paulo, n. 61, 2004, pp. 5-24; CASTRO, Marcus Faro de. Globalização, Democracia e Direito Constitucional: legados recebidos e possibilidades de mudança. In: CLEVE, Clermerson Merlin; FREIRE, Alexandre (cords.). Direitos Fundamentais e Jurisdição Constitucional: análise, crítica e contribuições. São Paulo: Revista dos Tribunais, 2014, pp. 697-719.
} 
almeja-se evidenciar os parâmetros efetivos e empíricos de constrangimento do poder político pelo próprio poder disperso, sob as luzes do problema aristotélico das facções políticas em cotejo com os desafios atuais do Estado no século XXI. No contexto desta pesquisa, busca-se à revisitação da instituição jurídica da divisão funcional do poder para pensar as faculdades emergenciais em seara financeira e respectiva dinâmica de freios e contrapesos como contingência da ação política.

Aliás, o Direito Constitucional Comparado dá conta de, pelo menos, três perguntas fundamentais acerca da relação entre constitucionalismo e emergências: quais instituições governamentais devem responder às emergências? Com base em que princípios substanciais essa resposta deve ocorrer? O constitucionalismo, como comprometimento ao Estado de Direito, é possível durante períodos emergenciais? ${ }^{343}$

As respostas a essas perguntas variam de acordo com o contexto socioeconômico e institucional do estado territorial adotado como referencial, assim como em decorrência do tipo de ameaças enfrentadas, uma vez que a emergência é termo dotado de certa ambiguidade a qual comporta desde desastres naturais à política externa. Nesse sentido, torna-se cabível a pergunta de Vicki Jackson e Mark Tushnet: a categoria do "poder de emergência" (emergency power) é útil para o design constitucional, especialmente para responder a uma ampla variedade de possíveis crises? ${ }^{344}$

No plano do ideário político ocidental, tem-se que já no período republicano da Roma Antiga, diante do problema da conservação da forma de governo em face de situações emergenciais, criou-se a instituição da ditadura romana na qual um cidadão eminente em tempos dificultosos era chamado pelos oficiais ordinários para receber temporariamente poderes extraordinários de defesa da República. De todo modo, no tocante às finanças públicas, ressalte-se que o ditador era inteiramente dependente do Senado em assuntos financeiros, porquanto era exigido daquele a autorização deste para a realização de saques do Tesouro Público. ${ }^{345}$

Igualmente, sabe-se que a indagação sobre a manutenção da ordem política frente a situações emergenciais não é nova no âmbito da filosofia política. No Estado moderno,

\footnotetext{
343 JACKSON, Vicki C.; TUSHNET, Mark. Comparative Constitutional Law. 3 ed. Nova York: Foundation Press, 2014, p. 896.

344 JACKSON, Vicki C.; TUSHNET, Mark. Comparative Constitutional Law. 3 ed. Nova York: Foundation Press, 2014, p. 872.

345 ROSSITER, Clinton L. Constitutional Dictatorship: crisis governement in the modern democracies. Princeton: Princeton University Press, 1948, pp. 16-24.
} 
observam-se reflexões teóricas acerca do relacionamento entre o poder político, as finanças públicas e as emergências nos pensamentos, sem pretensões metafísicas e de cunho prático, de Nicolau Machiavel ${ }^{346}$ e do Barão de Montesquieu ${ }^{347}$. A propósito, repise-se não haver aqui intenção de argumentar pela evolução histórico-filosófica dessa problemática ${ }^{348}$, mas apenas fazer referência a sua persistência na tradição pública ocidental por vários séculos, na qualidade de problema estruturante da política.

$\mathrm{Na}$ atual quadra histórica, percebe-se que o avanço tecnológico e a transnacionalização de problemas constitucionais, tais como desastres ambientais, terrorismo e guerras, colocam no horizonte de visão uma série de ameaças imprevisíveis e de difícil reparação. No entanto, deve-se atentar preventivamente para que a reação estatal, principalmente em sua dimensão financeira, não leve a um ciclo repressivo em prol de pretensa segurança e em detrimento das liberdades civis. Nesse sendeiro, Bruce Ackerman advoga em favor de um desenho autoconsciente de um regime emergencial como melhor alternativa contra um ciclo movido por pânico de destruição permanente das liberdades. Ainda de acordo com o jurista norteamericano, uma emergência constitucional deve ser enfrentada com um sistema político inovador de freios e contrapesos os quais possibilitem respostas efetivas em curto-prazo, mas

\footnotetext{
346 "E se vós disserdes: 'iremos ao rei’, parece-me que vos disse também isso: que o rei não se encontra em condições de defender-vos, uma vez que os tempos não são idênticos e nem sempre se consegue impedir a ação armada de outro (...) E deve-se lembrar aqui o que sucedeu quando os turcos tomaram Constantinopla. $\mathrm{O}$ imperador previu a ruína; chamou os súditos; não sendo capaz de prover à defesa com as rendas ordinárias, expôs-lhes os riscos, apresentou-lhes os remedies e estes não lhe deram ouvidos. Adveio o cerco. Os cidadão que não quiseram escutar os apelos de seu senhor, quando ouviram soar a artilharia nas suas muralhas e avançar o exército inimigo, correram ao imperador, chorando e com sacos repletos de dinheiro; este os expulsou dizendo: "podeis morrer com o vosso dinheiro, porque não quisestes viver sem ele '." (MAQUIAVEL, Nicolau. Discurso sobre a Maneira de Prover-se de Dinheiro. In: MAQUIAVEL, Nicolau. O Príncipe - Escritos Políticos. Trad. Olívia Balduh. São Paulo: Nova Cultural, 2000, p. 246.)

347 "Regra geral: pode-se arrecadar tributos mais elevados, na proporção da liberdade dos súditos, e é-se forçado a moderá-los na medida em que a servidão aumenta (...) A consequência de semelhante situação é o perpétuo aumento dos impostos, o que anula todos os remédios futuros; não se conta mais com as rendas, mas faz-se guerra com seu capital. Não é mais um fato inédito ver Estados hipotecarem seus fundos durante a própria paz e utilizarem, para se arruinar, meios que chamam de extraordinários e que são tão excessivos que o filho-família mais estróina mal o imagina." (MONTESQUIEU. Do Espírito das Leis. Trad. Fernando Henrique Cardoso e Leôncio Martins Rodrigues. 2 ed. São Paulo: Abril Cultural, 1979, pp. 194-196)

${ }^{348}$ Concorda-se, portanto, com a seguinte avaliação: "Quase três séculos depois, já passa da hora de repensar a santíssima trindade de Montesquieu. Apesar de seu status canônico, ela nos mantêm cegos para o surgimento, em nível mundial, de novas formas institucionais que não podem ser categorizadas como legislativas, judiciárias ou executivas. Embora a tradicional fórmula tripartite falhe ao capturar os modos característicos de operação de tais formas, essas unidades novas e funcionalmente independen- tes estão desempenhando um papel cada vez mais relevante em governos modernos. Uma 'nova separação de poderes' está emergindo no século XXI. A compreensão de suas características distintivas requer o desenvolvimento de um modelo conceitual que contenha cinco ou seis categorias - ou talvez mais. E, assim, nós devemos dar um carinhoso adeus a Montesquieu, para então criar novas bases para o direito administrativo comparado, que deem conta dos desafios dos governos modernos." (ACKERMAN, Bruce. Adeus, Montesquieu. In: Revista de Direito Administrativo, Rio de Janeiro, v. 265, jan./abr. 2014, pp. 13-23, p. 15)
} 
não viabilizem uma exceção permanente. ${ }^{349}$

Por conseguinte, no âmbito da presente pesquisa, pretende-se tratar de maneira prescritiva a realidade empírica da abertura dos créditos extraordinários por meio de medidas provisórias no período de 2008-2015 no contexto da União na República brasileira. Após, almeja-se tecer considerações normativas sobre interpretações de diagnósticos.

\subsubsection{O Poder Executivo e a abertura de créditos extraordinários}

$\mathrm{Na} \mathrm{CR} / 88$, as MPs foram concebidas como instrumentos normativos editados pela PR para fins de interferência direta e primária na ordem jurídica, nas hipóteses de matéria relevante e urgente. Em relação à lei orçamentária, percebe-se como regra geral a vedação de tratamento da matéria por MP, salvo os casos de abertura de crédito extraordinário face às despesas imprevisíveis e urgentes. Isso porque o sistema orçamentário previsto na ordem constitucional vigente prima pela titularidade da elaboração orçamentária direcionada ao Poder Legislativo, como forma de influência do Povo, por meio de seus representantes eleitos, nas macro-políticas de alocação de recursos públicos para a persecução dos objetivos estatais.

Assim sendo, a exceção fica por conta da abertura de créditos extraordinários frente às despesas imprevisíveis e urgentes. A esse respeito, sistematizam-se esses créditos abertos ao longo da vigência dos últimos dois PPAs no seguinte quadro, à luz do Anexo $\mathrm{C}$ desta pesquisa:

Quadro 3 - Abertura de créditos extraordinários por MP em função do exercício financeiro

\begin{tabular}{|l|l|l|l|l|l|l|}
\hline \multirow{2}{*}{ Exercício } & \multirow{2}{*}{$\begin{array}{c}\text { Quantidade } \\
\text { de MPs }\end{array}$} & \multicolumn{4}{|c|}{ Resultado } & \multirow{2}{*}{$\begin{array}{c}\text { R\$ (em } \\
\text { bilhões) }\end{array}$} \\
\cline { 3 - 6 } & & $\begin{array}{l}\text { Conversão } \\
\text { em lei }\end{array}$ & $\begin{array}{l}\text { Veto } \\
\text { Parcial }\end{array}$ & $\begin{array}{l}\text { Vigência } \\
\text { encerrada }\end{array}$ & Rejeição & \\
\hline 2015 & 6 & 4 & 1 & 1 & 0 & 124,5 \\
\hline 2014 & 6 & 1 & 0 & 5 & 0 & 34,1 \\
\hline
\end{tabular}

${ }^{349}$ ACKERMAN, Bruce. The Emergency Constitution. In: Yale Law Journal, New Haven-EUA, v. 113, 2004, pp. 1029-2004, pp. 1030-1031. 


\begin{tabular}{|l|l|l|l|l|l|l|}
\hline 2013 & 8 & 5 & 1 & 2 & 0 & 17,4 \\
\hline 2012 & 9 & 7 & 0 & 2 & 0 & 12,1 \\
\hline 2011 & 5 & 4 & 0 & 1 & 0 & 2,3 \\
\hline 2010 & 8 & 6 & 0 & 1 & 1 & 35,5 \\
\hline 2009 & 4 & 4 & 0 & 0 & 0 & 20,4 \\
\hline 2008 & 5 & 4 & 0 & 0 & 1 & 24 \\
\hline Total & 51 & 35 & 2 & 11 & 2 & 270,3 \\
\hline
\end{tabular}

Fonte: elaboração própria com base no Anexo C.

Em suma, tem-se uma média aritmética de 6 (seis) MPs editadas por exercício financeiro, ao passo que a taxa de sucesso do Poder Executivo é de 72,5\%, descontada a exigência de a matéria ser aprovada ao longo do mandato do presidente que submeteu a medida e o sucesso político representado pela caducidade de uma MP de natureza orçamentária, acompanhada ou não de um ato declaratório do Congresso Nacional, estabilizando as relações jurídicas travadas sob a égide da MP, isto é, a autorização tácita de despesas realizadas no curso de sua vigência.

De todo modo, as taxas de sucesso e dominância governamental são elevadas, caso o parâmetro seja a produção legislativa em geral. Nesse sentido, Fernando Limongi pontifica o seguinte: "Para resumir: o que o Executivo submete ao Legislativo é, em geral, aprovado. E, por definição, as matérias só podem ser aprovadas se contam com o apoio da maioria. Para evitar mal entendidos, cabe notar que a afirmação se estende às Medidas Provisórias." 350

Nesse cenário, diversas conclusões podem ser extraídas, ainda que não haja pretensões econométricas. De plano, percebe-se não só a iterativa utilização do instrumento orçamentário de cunho emergencial (periodicidade), mas também o impacto fiscal das despesas públicas tidas como imprevisíveis e urgentes (volume).

Em relação à frequência, a quantidade de 51 (cinquenta e uma) MPs voltadas à

${ }^{350}$ LIMONGI, Fernando. A Democracia no Brasil: presidencialismo, coalizão e processo decisório. In: Novos Estudos, n. 76, nov. 2006, pp. 17-41, p. 21. 
abertura de crédito extraordinário ganha significância no universo de 289 (duzentas e oitenta e nove) MPs editadas no período, o que representa uma razão de 1,5 a cada 10 MPs. Igualmente, a título comparativo, percebe-se que no exercício legislativo de 2015 foram promulgadas 163 (cento e sessenta e três) leis ordinárias pela Presidência da República ${ }^{351}$. Assim, desponta um problema de legitimidade democrática por parte da legislação governamental, tendo em conta a existência de um Poder Legislativo federal com 513 (quinhentos e treze) deputados e 81 (oitenta e um) senadores.

Ademais, para além da constância das ocorrências de despesas consideradas imprevisíveis e urgentes, nota-se ser o último mês do exercício financeiro (dezembro) o período em que mais se deu a edição dessas MPs, 12 (doze) vezes. Nesse ponto, a despeito de não se pressupor correlação temporal entre calamidades públicas, comoções internas e guerras e determinado momento do ano, é importante ressaltar que o princípio da anualidade orçamentária comporta como exceção aqueles créditos especiais e extraordinários cujos atos de autorização forem realizados nos últimos quatro meses do ano, a partir do qual são facultadas suas incorporações no orçamento público do exercício subsequente nos limites de seus saldos, nos termos do art. $167, \S 2^{\circ}$, da CR/88. ${ }^{352}$

Do mesmo modo, torna-se interessante observar os picos de utilização das MPs nos anos de 2010 e 2014, haja vista a simultaneidade dos pleitos eleitorais estaduais e federais no período em tela. Logo, há razões para supor um esforço de apresentar um desempenho governamental aquém da capacidade econômica do Estado como prevista no período de elaboração do orçamento público em ano eleitoral, sem representar, contudo, ganho de eficiência, mas apenas maior disponibilidade de recursos. No particular, encontram guarida empírica as teses de vinculação da política orçamentária federal e os incentivos eleitorais, notadamente por mediação dos partidos políticos. ${ }^{353}$

No tocante ao volume de recursos, não se observa uma relação direta entre o número de MPs e os montantes previstos em cada diploma legal ou globalmente considerados em um exercício financeiro. Por outro lado, fatores de natureza política e macroeconômica são

\footnotetext{
${ }^{351}$ Disponível em: <http://www4.planalto.gov.br/legislacao/legislacao-1/leis-ordinarias/2015-leis-ordinarias>. Acesso em 04.07.2016.

${ }^{352}$ Art. 167. São vedados: (...)§ $2^{\circ}$ Os créditos especiais e extraordinários terão vigência no exercício financeiro em que forem autorizados, salvo se o ato de autorização for promulgado nos últimos quatro meses daquele exercício, caso em que, reabertos nos limites de seus saldos, serão incorporados ao orçamento do exercício financeiro subseqüente.

${ }^{353}$ Cf. FIGUEIREDO, Argelina Cheibub; LIMONGI, Fernando. Incentivos Eleitorais, Partidos e Política Orçamentária. In: Dados, Rio de Janeiro, v. 46, n. 2, 2002, pp. 303-344.
} 
relevantes para a compreensão das quantias em questão. Nota-se que o exercício financeiro de 2015 foi responsável por quase metade (46\%) dos valores envolvidos na vigência dos dois últimos PPAs.

Nessa seara, coloca-se em questão o descompasso entre as fases de elaboração e execução do orçamento público, à luz da contração econômica refletida no PIB brasileiro e na arrecadação tributária federal, sendo que esta registrou variação real de $-4,32 \%$ no cotejo de dezembro de 2014 e $2015^{354}$, ao passo que das LOAs para os exercícios financeiros de 2014 e 2015 extrai-se uma expectativa de aumento nas estimativas de receitas públicas de $\mathrm{R} \$ 2,488$ trilhões para $\mathrm{R} \$ 2,98$ trilhões.

Ainda em termos quantitativos, explicita-se a dimensão dos créditos extraordinários abertos, ao compará-los com as despesas previstas nos orçamentos fiscal e de seguridade social por órgão orçamentário no Anexo II da LOA para o exercício financeiro de 2015, embora se deva considerar a evolução da inflação econômica no período analisado. A título de comparação, as despesas previstas para o custeio das políticas públicas dos Ministérios da Defesa (R\$ 81,5 bi), Integração Nacional (R 7 bi), Agricultura, Pecuária e Abastecimento ( R \$ 11,7 bi), Desenvolvimento Agrário ( $\mathrm{R}$ \$ 5,8 bi), Desenvolvimento Social e Combate à Fome (R\$ 75,3 bi) e Cidades (R \$ 33,2 bi). Noutra banda, o Anexo IV da mesma lei fixou R\$ 105,8 bilhões como Orçamento de Investimento da União, o que, por si só, representa uma quantia inferior aos valores abertos por créditos extraordinários no exercício financeiro de 2015.

Feita essa primeira aproximação de índole mais quantitativa, passa-se ao exame das opções políticas do Poder Executivo no manejo do instrumento orçamentário em comento. Nessa perspectiva mais qualitativa, serão priorizados estudos de casos selecionados de acordo com as políticas públicas promovidas e a relevância orçamentária da medida.

Em primeiro lugar, observa-se uma desarticulação institucional em uma série de episódios, traduzível em tensões entre os Poderes Executivo e Legislativo nos âmbitos da elaboração e da execução orçamentárias, sendo esta fase com auxílio do TCU. Dois casos claros do que se fala são os maiores créditos extraordinários abertos no curso do período analisado.

${ }^{354}$ BRASIL. MINISTÉRIO DA FAZENDA. Análise da Arrecadação das Receitas Federais: dezembro/2015. Brasília: Centro de Estudos Tributários e Aduaneiros, 2016. Disponível em: <http://idg.receita.fazenda.gov.br/dados/receitadata/arrecadacao/relatorios-do-resultado-daarrecadacao/arrecadacao-2015/dezembro2015/analise-mensal-dez-2015.pdf>. Acesso em: 04.07.2016. 
Na MP 702, de 17 de dezembro de 2015, o Chefe do Poder Executivo abriu crédito na ordem de R \$ 37,5 bilhões, sendo R \$ 2,5 bilhões dedicados ao Ministério da Saúde, em razão de epidemias de dengue, chikungunya e zika vírus, enquanto o restante foi direcionado aos Ministérios do Trabalho e Emprego e das Cidades, bem como aos Encargos Financeiros da União, de modo a pagar passivos e valores devidos nesse exercício financeiro, consoante as determinações presentes nos Acórdãos 828/2015 355 e 992/2015 do Plenário do TCU, ambos sob a relatoria do Ministro José Múcio Monteiro e originados de um processo de representação apresentado pelo Ministério Público junto ao TCU, com informações de atrasos nos repasses, a instituições financeiras pertencentes ou controladas pelo Poder Público Federal, de valores destinados ao pagamento de despesas de responsabilidade da União.

Nessa demanda, acentuaram-se as seguintes funções constitucionais do TCU ${ }^{356}$ : a fiscalizadora (contábil, financeira e orçamentária na seara de instituição de uma gestão fiscal responsável, à luz da LRF); a informativa (representação ao poder competente sobre irregularidades ou abusos apurados, nos termos do art. 71, XI, da CR/88); e a sancionadora (aplicação aos responsáveis, em caso de ilegalidade de despesa ou de irregularidade de contas, das sanções previstas na Lei 8.443/92).

Sob o ponto de vista de cumprimento da LRF, soa paradoxal um dissenso interpretativo basilar entre os órgãos estatais em relação a uma prática institucional, sobretudo pelo fato do diploma legal em exame se fundamentar nos eixos do planejamento, transparência, controle e responsabilização. ${ }^{357}$ Nesse sentido, é pouco sustentável argumentar pela ocorrência de despesa imprevisível e urgente nesse ponto.

Outro caso de desarticulação entre Governo e Parlamento mostrou-se na MP 667, de 02 de janeiro de 2015, na qual se abriu crédito extraordinário na ordem de R $\$ 74$ bilhões com o fito de viabilizar a execução de investimentos e inversões financeiras no exercício de 2015 , com destaque para grandes obras de infraestrutura em andamento ou a serem implementadas

\footnotetext{
355 "Representação. Indícios de atrasos e outras irregularidades nos repasses do Governo Federal a instituições financeiras e aos demais entes federados. Ausência de registro de dívidas e despesas primárias nas estatísticas fiscais. Obtenção de crédito em desconformidade com a lei de responsabilidade fiscal. Determinações. Audiências. Encaminhamento dos autos ao Ministério Público Federal.”

356 "Pensamos que se pode, no que concerne às funções básicas do Tribunal de Contas da União, classifica-las em oito categorias: judicante ou jurisdicional, fiscalizadora, consultiva, informativa, sancionadora, corretiva, normativa e de ouvidoria." (BUGARIN, Paulo Soares. O Princípio Constitucional da Economicidade na Jurisprudência do Tribunal de Contas da União. 2 ed. Belo Horizonte: Fórum, 2011, p. 83)

${ }^{357}$ BUGARIN, Paulo Soares. O Princípio Constitucional da Economicidade na Jurisprudência do Tribunal de Contas da União. 2 ed. Belo Horizonte: Fórum, 2011, p. 87.
} 
pelo Governo Federal. Nesse caso, a relevância e urgência da medida ${ }^{358}$ justificou-se pela não aprovação do projeto de LOA para o exercício financeiro em tempo hábil, a despeito de a mesma situação ter se passado em sucessivos anos anteriores. ${ }^{359}$

Há, portanto, dois problemas relevantes. O primeiro diz respeito ao sistema presidencialista brasileiro, principalmente na dinâmica orçamentária, pois a transição entre as fases de elaboração, cuja titularidade é do Legislativo, e de execução, precipuamente realizada pelo Executivo, do orçamento público ocorre com ausência de planejamento, transparência e controle no plano da atividade financeira do Estado, como se evidencia nesse caso concreto.

Do mesmo modo, constata-se confusão nos papéis institucionais dos Poderes na MP 598, de 27 de dezembro de 2012, na qual se fundamentou a necessidade do crédito por conta da não aprovação, até a edição do ato, de 14 (catorze) projetos de lei para abertura de créditos adicionais (6 especiais e 8 suplementares) encaminhados pelo Poder Executivo ao Congresso Nacional; e na MP 666, de 30 de dezembro de 2014, em que o crédito extraordinário se fez necessário para fazer frente à inexistência ou insuficiência de recursos orçamentários para tanto, em decorrência da não aprovação de 4 (quatro) projetos de lei para abertura de créditos adicionais (2 especiais e 2 suplementares) por parte do Poder Legislativo. Para além das instituições, nota-se um equívoco técnico e uma irresponsabilidade política ao se equiparar funcionalmente três tipos de créditos adicionais com finalidades e formalidades distintas, à luz de texto expresso da CR/88.

Igualmente, há colidência de entendimentos e vontades políticas, quando se justifica a edição de MP para abertura de crédito extraordinário com o fito de recomposição de recursos públicos direcionados aos Encargos Financeiros da União, tendo em vista a redução na programação de despesas efetuada pelo Congresso Nacional na tramitação do Projeto de LOA, tal como ocorreu na MP 654, de 12 de agosto de 2014, e na MP 686, de 19 de maio de 2015. Aliás, em abono à primazia do Legislativo na atribuição estatal de definir receitas e

\footnotetext{
${ }^{358}$ Pela impossibilidade jurídica desse expediente, Kiyoshi Harada argumenta o seguinte: "Ora, se inexistente a lei orçamentária anual, descabe a cogitação de abertura de crédito adicional extraordinário por via de medida provisória. a abertura desse crédito só se justifica na hipótese em que a lei orçamentária deixou de fixar determinada despesa porque não era previsível na época de sua elaboração" (HARADA, Kiyoshi. Direito Financeiro e Tributário. 25 ed. São Paulo: Atlas, 2016, p. 73)

${ }^{359} \mathrm{Na}$ verdade, o decurso do exercício financeiro sem a aprovação pelo Congresso Nacional da LOA para o exercício subsequente foi uma das maiores polêmicas na ANC em matéria de finanças públicas, atualmente se utiliza a regra do duodécimo relativa ao exercício financeiro anterior, por expressa autorização da LDO e aplicação analógica do art. 32 da Lei 4.320/64. Aliás, o constituinte José Serra é categórico ao afirmar que se trata de um dos dois conflitos básicos não resolvidos claramente pela $\mathrm{CR} / 88$, ao lado da configuração da autonomia financeira dos Poderes na definição de suas despesas próprias. Vide: SERRA, José. A Constituição e o Gasto Público. In: Planejamento e Políticas Públicas, Brasília, n. 1, jun. 1989, pp. 93-106.
} 
despesas da administração pública, o STF depreendeu do sistema constitucional a impossibilidade de atuação judicial nesse mister, salvo em situações graves e excepcionais, assim como desde que atendidas as condições do art. $166, \S \S 3^{\circ}$ e $4^{\circ}$, da CR/88, no bojo do julgamento da ADI 5.468, de relatoria do Ministro Luiz Fux. ${ }^{360}$ Nesses termos, vislumbra-se atuação governamental, por meio de créditos extraordinários, a fim de infirmar a decisão parlamentar acerca de alocação de verbas públicas.

Noutra banda, o segundo problema relevante que exsurge da precitada MP 667, também observada em mais de uma dezena de outras medidas provisórias, concerne ao financiamento de infraestrutura, empresas estatais e reaparelhamento do aparato governamental por intermédio de créditos extraordinários. Isso porque as despesas públicas voltadas a esses fins devem se pautar por um planejamento de médio-longo prazo previsto no PPA, nos termos do art. 167, I, da CR/88.

Além desse aspecto técnico, há outros fatores a serem levados em consideração. Primeiro, questiona-se a escolha política dos créditos extraordinários como tentativa de mitigar a falta de espaço fiscal para a realização de gastos em infraestrutura, enquanto há diversos outros instrumentos orçamentários ${ }^{361}$ muito mais eficientes e justos em termos integeracionais, à luz da importância estratégica da infraestrutura para o desenvolvimento nacional, como, por exemplo, a vinculação de receitas para a área, a fixação de despesa mínima obrigatória para esses gastos e a via do crédito público, desde que informado pela “regra de ouro" sui generis encartada no art. 167, $\mathrm{III}^{362}$, da CR/88.

Outro fator relevante é o estímulo à participação privada mediante um marco regulatório adequado, e não propriamente intervenção direta, haja vista a baixa capacidade do governo para conceber e implantar projetos de infraestrutura. ${ }^{363}$

Ademais, evidencia-se o baixo investimento público em infraestrutura, a ponto de o

\footnotetext{
360 "Decisão: O Tribunal, por unanimidade, aprovou tese fixada nos seguintes termos: 'Salvo em situações graves e excepcionais, não cabe ao Poder Judiciário, sob pena de violação ao princípio da separação de poderes, interferir na função do Poder Legislativo de definir receitas e despesas da administração pública, emendando projetos de leis orçamentárias, quando atendidas as condições previstas no art. $166, \S 3^{\circ}$ e $\S 4^{\circ}$, da Constituição Federal'. Ausentes, nesta assentada, os Ministros Gilmar Mendes e Dias Toffoli. Presidência do Ministro Ricardo Lewandowski. Plenário, 30.06.2016."

361 CARVALHO, André Castro. Infraestrutura sob a perspectiva pública: instrumentos para o seu desenvolvimento. 608 f. Tese de doutorado - Faculdade de Direito, Universidade de São Paulo, São Paulo, 2013, pp. 419 e ss.

${ }^{362}$ Art. 167. São vedados: (...)III - a realização de operações de créditos que excedam o montante das despesas de capital, ressalvadas as autorizadas mediante créditos suplementares ou especiais com finalidade precisa, aprovados pelo Poder Legislativo por maioria absoluta.

${ }^{363}$ VELLOSO, Raul et al. Infraestrutura: os caminhos para sair do buraco. Rio de Janeiro: Instituto Nacional de Altos Estudos, 2012, passim.
} 
estoque de infraestrutura do Brasil decrescer. De acordo com Raul Velloso, "Infelizmente, parece ser este o caso do Brasil, onde, já há quase três décadas, investimos entre $2 \%$ e $3 \%$ do PIB em infraestrutura. Sendo assim, o Brasil, na melhor das hipóteses, tem conseguido repor o capital de infraestrutura que se deprecia." ${ }^{364}$ No particular, as destinações dos créditos extraordinários não fogem a essa regra, uma vez que se observam dotações orçamentárias direcionadas ao reaparelhamento das empresas estatais, dos Ministérios e até de escolas e hospitais, inclusive sob a forma de transferências aos Estados e Municípios. ${ }^{365}$

A esse pretexto, chega-se a evidentes desvirtuamentos do instrumento do crédito adicional extraordinário. Na MP 709/2015, convertida na Lei 13.275, de 27 de abril de 2016, alterou-se o programa de trabalho da LOA de 2016 para destinar R \$ 37,5 milhões para a "Implantação e Modernização de Infraestrutura para Esporte Educacional, Recreativo e de Lazer", sob a responsabilidade do Ministério do Esporte, assim como R\$ 72,7 milhões para "Apoio a Projetos de Infraestrutura Turística", levado a cabo pelo Ministério do Turismo.

A propósito, nesse mesmo diploma legal, por proposta da Chefia do Poder Executivo e com aval do Congresso Nacional, foram previstas as aplicações de $\mathrm{R} \$ 2,5$ milhões para o Ministério da Cultura com o fito de "Implantação, Instalação e Modernização de Espaço e Equipamentos Culturais" em municípios do Rio Grande Sul e Promoção e "Fomento à Cultura Brasileira" no Município de Osasco-SP; e de R\$ 10 milhões para "Publicidade de Utilidade Pública" por parte do Ministério do Esporte. Repise-se: não se discute a relevância sócio-econômica dessas atividades, mas a clara ausência dos requisitos de imprevisibilidade e urgência dessas despesas públicas.

Posta a situação da infraestrutura pública, chama também atenção, sob as perspectivas quantitativa e qualitativa, a utilização de créditos extraordinários para o financiamento do direito à educação, principalmente na forma de políticas públicas de acesso ao ensino superior sob a responsabilidade da União, como são os casos do FIES e Pronatec, destinados, respectivamente, para o incremento do mercado de crédito estudantil e a oferta de ensino profissionalizante.

Em termos de impacto fiscal, não há dúvidas de que a situação do FIES é notável.

\footnotetext{
${ }^{364}$ VELLOSO, Raul. Para Destravar o Investimento em Rodovias. In: VELLOSO, Raul; MENDES, Marcos; FREITAS, Paulo Springer de. O Dia do Juízo Fiscal. Rio de Janeiro: Instituto Nacional de Altos Estudos, 2016, p. 113.

${ }^{365}$ Confiram-se, a propósito, as MPs 420, 423, 424, 473, 490, 498, 531, 573, 625, 662, 666, 667 e 709.
} 
Trata-se de um fundo público de natureza contábil instituído pela Lei 10.260/2011 destinado à concessão de financiamento a estudantes regularmente matriculados em cursos superiores não gratuitos e com avaliação positiva nos processos de avaliação governamental. Desde 2010, o FIES passou a funcionar em formato mais favorável a seus beneficiários ${ }^{367}$, visando à ampliação a fruição do acesso ao ensino superior, sem arcar com os onerosos custos das universidades públicas. Ocorre que no período de 2013 a 2015, foram editadas seis medidas provisórias ${ }^{368}$ cujos objetos eram a abertura de crédito extraordinário para esse fundo público, totalizando mais de $\mathrm{R}$ \$22,5 bilhões somente nessa espécie de crédito.

Ademais, por força da Lei $12.202 / 2010^{369}$, o FIES passou a beneficiar alunos da educação profissional de nível médio, bem como os matriculados em programas de pósgraduação stricto sensu. Com o advento do Pronatec, positivado na Lei $12.513 / 2011^{370}$, o fundo de natureza contábil indigitado passou também a ter como finalidade financiar a educação profissional e tecnológica, desde que haja disponibilidade de recursos.

Nesse contexto, a MP 548, de 28 de outubro de 2011, fora editada com o fito de abrir crédito extraordinário no valor de $\mathrm{R} \$ 460,5$ milhões em prol do Fundo Nacional de Desenvolvimento da Educação, responsável tanto pelo FIES, quanto pelo Pronatec, porque a segunda política pública foi criada sem lastro financeiro para a respectiva execução. ${ }^{371}$

\footnotetext{
${ }^{366}$ BRASIL. PRESIDÊNCIA DA REPÚBLICA. Lei 10.260, de 12 de junho de 2001. Dispõe sobre o Fundo de Financiamento ao Estudante do Ensino Superior e dá outras providencias. Diário Oficial da União, Brasília, Seção 1, Publ. em 13.07.2001, p. 2.

367 "Em 2010, o FIES passou a funcionar em um novo formato: a taxa de juros do financiamento passou a ser de 3,4\% a.a., o período de carência passou para 18 meses e o período de amortização para 3 (três) vezes o período de duração regular do curso +12 meses. O Fundo Nacional de Desenvolvimento da Educação (FNDE) passou a ser o Agente Operador do Programa para contratos formalizados a partir de 2010. Além disso, o percentual de financiamento subiu para até $100 \%$ e as inscrições passaram a ser feitas em fluxo contínuo, permitindo ao estudante o solicitar do financiamento em qualquer período do ano." Disponível em: <http://sisfiesportal.mec.gov.br/?pagina=fies> . Acesso em 15.07.2016.

${ }^{368}$ Em ordem crescente: MPs 588, 626, 626, 642, 655 e 686.

${ }^{369}$ BRASIL. PRESIDÊNCIA DA REPÚBLICA. Lei 12.202, de 14 de janeiro de 2010. Altera a Lei 10.260, de 12 de julho de 2001, que dispõe sobre o Fundo de Financiamento ao Estudante do Ensino Superior - FIES. Diário Oficial da União, Brasília, Seção 1, Publ. em 15.01.2010, p. 3.

${ }^{370}$ BRASIL. PRESIDÊNCIA DA REPÚBLICA. Lei 12.531, de 26 de outubro de 2011. Institui o Programa Nacional de Acesso ao Ensino Técnico e Emprego (Pronatec); altera as Leis 7.998, de 11 de janeiro de 1990, que regula o Programa do Seguro-Desemprego, o Abono Salrial e institui o Fundo de Amparo ao Trabalhador (FAT), 8.212. de 24 de julho de 1991, que dispõe sobre a organização da Seguridade Social e institui o Plano de Custeio, 10.260, de 12 de juhlo de 2011, que dispõe sobre o Fundo de Financiamento do Ensino Superior, e 11.129, de 30 de junho de 2005, que institui o Programa Nacional de Inclusão de Jovens (ProJovem); e dá outras providencias. Diário Oifical da União, Brasília, Seção 1, Publ. em 27.10.2011, p. 1.

${ }^{371}$ Reproduz-se, a propósito, excerto da Exposição de Motivos da MP em comento: "2. O presente crédito visa à implantação de novas iniciativas, como a oferta de bolsas para formação de estudantes e trabalhadores e o financiamento da educação profissional e tecnológica, em decorrência da aprovação pelo Senado Federal do Projeto de Lei no $1.209 / 2011$, em fase de sanção, o qual institui o Programa Nacional de Acesso ao Ensino Técnico e Emprego - PRONATEC, que representa medida de extremo impacto para a melhoria da qualidade da
} 
No mesmo período, convém observar a evolução das despesas primárias do Governo Federal com a educação como proporção da receita líquida:

Tabela 1 - Despesa primária em educação do Governo Federal como proporção da receita líquida (\%)

\begin{tabular}{|l|l|l|l|l|l|l|l|l|l|l|l|l|}
\hline & 2006 & 2007 & 2008 & 2009 & 2010 & 2011 & 2012 & 2013 & 2014 & 2015 & $\begin{array}{l}\text { Média } \\
2013- \\
2015\end{array}$ & $\begin{array}{l}\text { Contribuição } \\
\text { ao aumento } \\
\text { da despesa } \\
\text { ádia } \\
\text { vs. } \\
2006- \\
2013-2015 \\
\text { vs. } \\
2006- \\
2008)\end{array}$ \\
\hline $\begin{array}{l}\text { Mínimo } \\
\text { obrigatório }\end{array}$ & 2,4 & 3,4 & 3,5 & 3,7 & 4,8 & 4,5 & 3,9 & 4,5 & 5,2 & 5,2 & $61 \%$ & $13 \%$ \\
\hline $\begin{array}{l}\text { Acima do } \\
\text { Mínimo } \\
\text { obrigatório }\end{array}$ & 1,2 & 0,1 & 0,2 & 0,6 & 0,4 & 0,3 & 1,7 & 1,1 & 1,5 & 1,4 & $183 \%$ & $6 \%$ \\
\hline
\end{tabular}

Fonte: VELLOSO, Raul; MENDES, Marcos. O Dia do Juízo Fiscal. In: VELLOSO, Raul; MENDES, Marcos; FREITAS, Paulo Springer de. O Dia do Juízo Fiscal. Rio de Janeiro: Instituto Nacional de Altos Estudos, 2016, pp. 22-23.

Para fins desta análise, algumas premissas precisam restar claras. Em primeiro lugar, não há dúvidas sobre a correlação intergeracional entre a educação e a renda da população, assim sendo a efetividade da redução das desigualdades sociais e regionais e da estratificação social brasileira perpassa necessariamente pelas instituições educacionais, como se depreende

formação e qualificação profissional, como política de inserção social a milhões de jovens e trabalhadores brasileiros, oferecendo a eles a oportunidade de participação no desenvolvimento do País. 3. O PRONATEC abrange ações já em andamento, como é o caso da ampliação de vagas e expansão das redes atuais, além de propor outras, como a oferta de bolsas para formação de estudantes e trabalhadores e o financiamento da educação profissional e tecnológica. 4. A urgência e relevância da medida decorrem da necessidade de entrega tempestiva de recursos às instituições de educação profissional e tecnológica das redes públicas estaduais e municipais ou dos serviços nacionais de aprendizagem, possibilitando a distribuição de vagas na educação profissional e tecnológica de forma mais equânime pelo território nacional, para maior contribuição ao desenvolvimento tecnológico do País, como suporte estratégico ao desenvolvimento social, criando oportunidades de formação profissional aos trabalhadores e jovens estudantes brasileiros e condições favoráveis para sua inserção no mercado de trabalho, e o enfrentamento de um dos maiores desafios para continuidade do crescimento econômico do País, que é a falta de mão de obra qualificada. 5. Com efeito, a implementação do mencionado Programa é indispensável para assegurar cobertura integral à educação profissional e tecnológica. Além de extremamente relevante, a medida ora proposta também é urgente, a fim de assegurar a implementação dele para o início do mês de novembro 2011, bem como o não comprometimento do início do próximo ano letivo. $O$ rito legislativo usual poderia dilatar a implementação desses programas para a educação profissional e tecnológica como um todo. Portanto, estão presentes os requisitos de relevância e urgência que legitimam a edição de medida provisória, nos termos do art. 62 da Constituição Federal. 6. Ressalta-se, ainda, que o Projeto de Lei em comento foi encaminhado pelo Poder Executivo para a Câmara dos Deputados Federais em 29 de abril de 2011, com solicitação de urgência para a apreciação da matéria, cuja conclusão da apreciação do PL no 1.209/2011 só veio a ocorrer em 31 de agosto de 2011, pela Câmara, e em 18 de outubro de 2011, pelo Senado Federal, tendo sido remetido à sanção presidencial em 21 de outubro de 2011." (grifos nossos) 
dos estudos comparativos e empíricos de Thomas Pikkety. ${ }^{372}$ Nesse sentido, cada vez mais se torna inevitável pensar em volumosos investimentos financeiros por parte do Estado em capital humano, inclusive por meio da atividade administrativa de fomento às instituições privadas de ensino e ao mercado de crédito estudantil, com vistas à inserção do Brasil e respectivo mercado de trabalho nas cadeias globais de produção e consumo. ${ }^{373}$

Em segundo lugar, a educação é um direito fundamental previsto no art. 205 da $\mathrm{CR} / 88$, passível de sistematização da seguinte maneira ${ }^{374}$ : na dimensão subjetiva, é "direito de todos" e "dever do Estado e da família", logo é uma posição jurídica individualmente exigível e oponível na forma de direito subjetivo; em termos objetivos, incorpora-se à ordem objetiva de valores da comunidade política, uma vez que o dever do Estado para com a educação do Povo operacionaliza-se na forma dos arts. 208 e 211 da CR/88, inclusive com a distribuição procedimental das atividades administrativas a cada qual dos entes federativos. Nesse contexto, é função da dogmática jurídica fornecer bases sólidas e pragmáticas para o controle do orçamento público em bases jurídico-constitucionais, por intermédio da tensão produtiva entre o mínimo e o pleno já delineada no Capítulo 1 desta pesquisa. No caso particular da educação, há que se pensar em mecanismos de estabilidade de financiamento dos direitos sociais, informados pela suficiência financeira dos interesses públicos juridicamente qualificados e sem recair na regressividade do custeio às ações governamentais de cunho social. $^{375}$

Porém, essas premissas não isentam o expediente orçamentário das referidas MPs de críticas. Pelo contrário, revelam uma disfuncionalidade sistêmica, à luz de razões administrativas e financeiras. Assim, torna-se dificultoso sustentar fundamentos de juridicidade das políticas públicas supracitadas, tendo em vista a ausência de sistematicidade expressa na forma de desarticulação da ação governamental, ao ponto de se lançar um

\footnotetext{
${ }^{372}$ PIKKETY, Thomas. Capital in the Twenty-First Century. Trad. Arthur Goldhammer. Cambridge: Belknap Press of Harvard University Press, 2014, pp. 484-487.

373 "As perspectivas de superação desse quadro assentam nas possibilidades de o Brasil encetar uma nova estratégia (e estilo) de desenvolvimento e de inserção na economia mundial. Retomar níveis elevados de investimento, em segmentos capazes de competir vigorosamente em determinados nichos do mercado global, e assegurar bases no mercado interno são condições básicas para acompanhar as transformações em curso.

Isso exigirá a ampliação da capacidade de inovação em processos e produtos que, a seu turno, definirão os perfis de organização da produção dominante no sistema produtivo do país. E, por conseguinte, a configuração das demandas por força de trabalho e suas configurações de competências básicas e técnico-profissionais." (BRASIL. INSTITUTO DE PESQUISA ECONÔMICA APLICADA. Políticas Sociais: acompanhamento e análise. n. 22. Brasília: IPEA, 2014, p. 282)

${ }^{374}$ SARLET, Ingo Wolfgang. A Eficácia dos direitos fundamentaios: uma teoria geral dos direitos fundamentais na perspectiva constitucional. 10 ed. Porto Algre: Livraria do Advogado, 2010, pp. 141 e ss.

${ }^{375}$ PINTO, Élida Graziane. Financiamento dos Direitos à Saúde e à Educação: uma perspectiva constitucional. Belo Horizonte: Fórum, 2015, pp. 17-30 e pp. 47-79.
} 
programa nacional sem previsão orçamentária adequada, sob os riscos de descontinuidade administrativa, tirante o risco de inexecução de programas educacionais na ocorrência de trocas de comando político. ${ }^{376}$

O flagrante risco de descontinuidade e a alteração frequente no marco regulatório levaram, em última medida, a contenda ao STF, o qual por meio de Referendo à Medida Cautelar na ADPF 341, de relatoria do Ministro Luís Roberto Barroso, Tribunal Pleno, ratificou a impossibilidade de aplicação retroativa de novas normativas educionais. ${ }^{377}$ Do mesmo modo, sob a sistemática da repercussão geral, o Plenário do STF rejeitou a repercussão geral sobre "a possibilidade de adesão ao Fundo de Garantia de Operações de Crédito Educativo (FGEDUC) após a formalização de contrato de financiamento estudantil com o FIES (Fundo de Financiamento ao Estudante de ensino Superior)" no bojo do Tema 785, cujo recurso-paradigma é o ARE-RG 849.328, de relatoria do Ministro Teori Zavascki. $^{378}$

Aliás, a própria decisão financeira de se utilizar de créditos extraordinários para cobrir despesas correntes relativas à educação possui inconstestável déficit de legitimidade democrático, pois se abrem programas, investimentos e políticas públicas por este instrumento excepcional e instável a partir de critérios precipuamente tecnocráticos, portanto se coloca em questão a própria possibilidade de o orçamento público traduzir-se em ambiente de realização da democracia deliberativa na seara da atividade financeira do Estado.

Logo, remanesce uma série de dúvidas acerca da sustentatibilidade financeira de um modelo educacional em que sua funcionalidade pressuponha a conversão de políticas de estado presumivelmente perenes em emergências constitucionais, “urgentes" e "imprevisíveis", programadas em bases anuais, para fins de gerar um aumento vertiginoso nas despesas públicas na área educacional por fatores conjunturais. ${ }^{379}$

\footnotetext{
${ }^{376}$ BUCCI, Maria Paula Dallari. Fundamentos para uma Teoria Jurídica das Políticas Públicas. São Paulo: Saraiva, 2013, p. 253.

377 BRASIL. SUPREMO TRIBUNAL FEDERAL. Referendo em Medida Cautelar em Arguição de Descrumpirmento de Preceito Fundamental 341, Pleno, Rel. Min. Roberto Barroso, DJe 10.08.2015.

${ }^{378}$ BRASIL. SUPREMO TRIBUNAL FEDERAL. Recurso Extraordinário com Agravo 849.328, Pleno, Rel. Min. Teori Zavascki, DJe 19.12.2014.

${ }^{379}$ Parte dos economistas tem idenficado esses padrões com a existência de instituições extrativistas, veja-se, a propósito, a crítica de Paulo Castro ao que ele chama de "o mito do governo grátis", traduzível nos seguintes termos: "O mito do governante que seja capaz de produzir benefícios coletivos sem qualquer custo para a sociedade é a forma mais sofisticado de se criar a ilusão coletiva da gratuidade a respeito de tudo que seja ou provenha do setor público" (CASTRO, Paulo Rabello de. O Mito do Governo Grátis: o mal das políticas econômicas ilusórias e as lições de 13 países para o Brasil mudar. Rio de Janeiro: Edições de Janeiro, 2014, p. 22)
} 
Em suma, observa-se uma utilização reiterada de MPs para fins de abertura de créditos extraordinários, de modo que é possível afirmar que o manejo do orçamento público opera em uma espécie de "emergência programada", tendo em vista a periodicidade e o volume de créditos extraordinários instrumentalizados pela via das MPs com relação ao planejamento orçamentário globalmente considerado.

\subsubsection{O Poder Legislativo e a abertura de créditos extraordinários}

No campo da abertura de créditos extraordinários mediante MP, o desempenho institucional do $\mathrm{CN}$ não diverge em termos qualitativos do observado no relacionamento genérico entre Executivo-Legislativo na seara federal. Isso porque, em ambos os casos, "O governo controla a produção legislativa e esse controle é resultado da interação entre poder de agenda e apoio da maioria. Maioria reunida por uma coalizão partidária pura e simples.”380

Em termos amplos, a formação da agenda de governo $^{381}$ envolve as seguintes dimensões: o reconhecimento dos problemas a serem solucionados; a geração de propostas políticas para solucioná-los; e os eventos políticos que se relacionam com a opinião pública. ${ }^{382}$ Nesse sentido, o poder de agenda do Poder Executivo em relação ao Legislativo não se detém apenas na pauta de propostas submetidas à apreciação deste (“o quê?"), mas também na oportunidade em que isso se dará (“quando?”). ${ }^{383}$

No escopo da presente pesquisa, torna-se conveniente abordar o poder de agenda no presidencialismo de coalizão brasileiro em dois aspectos: a edição de MP e o ciclo orçamentário regente da atividade financeira do Estado.

A despeito de diferenças marcantes no padrão de interação entre Executivo e

\footnotetext{
${ }^{380}$ LIMONGI, Fernando. A Democracia no Brasil: presidencialismo, coalizão partidária e processo decisório. In: Novos Estudos, São Paulo, n. 76, nov. 2006, pp. 17-41, p. 25.

381 "O processo de formação da agenda se desenvolve no interior do arcabouço constitucional, de modo dependente do processo legislativo e, portanto, envolvendo as relações entre Executivo e Legislativo. Esse processo não depende exclusivamente da atividade administrativa, mas da utilização dos instrumentos constitucionais postos à disposição de ambos os poderes envolvidos, especialmente daqueles que conferem ao Executivo capacidade de influir no processo legislativo. O Executivo demanda algum apoio de sua base parlamentar para dar força e forma de lei aos seus atos e programas de governo." (VICTOR, Sérgio Antônio Ferreira. Presidencialismo de coalizão: exame do atual sistema de governo brasileiro. São Paulo: Saraiva, 2015, p. 111)

${ }^{382}$ VICTOR, Sérgio Antônio Ferreira. Presidencialismo de coalizão: exame do atual sistema de governo brasileiro. São Paulo: Saraiva, 2015, p. 111.

${ }^{383}$ SAMPAIO, Marco Aurélio. A Medida Provisória no presidencialismo de coalizão. São Paulo: Malheiros, 2007, p. 129.
} 
Legislativo nos diversos governos posteriores à redemocratização, é notável que todos esses tenham se valido do instrumento legislativo da MP para dar força e forma de lei a seus atos e planos governamentais, sejam aqueles relevantes e urgentes, sejam assuntos rotineiros da Administração Pública. Segundo Argelina Figueiredo e Fernando Limongi, a reação do CN à utilização iterativa desse expediente tem sido, em geral, "dócil", porquanto "Raramente questionou a admissibilidade das MPs emitidas, ou seja, não contestou o juízo do Executivo quanto à sua relevância e urgência, aprovando a grande maioria delas." 384

Como premissa de raciocínio, deve-se ter em mente que a concessão de uma "carta branca" ao Executivo em matéria de função legislativa atípica foi uma opção constituinte levada a efeito na ANC, de modo a garantir um processo decisório ágil e livre de obstáculos para garantir a governabilidade em períodos de crise $^{385}$, inclusive de índole econômica e financeira. ${ }^{386}$

Posto o fundamento dessa instituição jurídica, conclui-se ser sua teleologia marcada pela excepcionalidade. Logo, a banalização do instrumento na corrente experiência brasileira possui a aptidão de alijar o Poder Legislativo do processo de elaboração de políticas públicas e, mais importante aqui, respectivo financiamento. ${ }^{387}$

Em síntese, são distinguíveis três efeitos políticos da MP: o incentivo institucional ao PR para que governe baseado unicamento nesse instrumento; a manutenção da tradição brasileira de um Executivo forte e ativo, por sua vez pareado por um Legislativo inerte ou, quando muito, reativo; e a alteração do momento de análise e deliberação parlamentar acerca das políticas públicas, que passa a ser posterior à implementação destas. ${ }^{388}$

Portanto, com base nos poderes institucionais reforçados da PR e na possibilidade de formação de um governo que organizou seu apoio político com base em coalizões montadas a partir de critérios partidários, não necessariamente programáticos, a escolha parlamentar para a influência na ação governamental, em termos de políticas públicas, é binária: ou adere à coalizão presidencial na legislatura em curso, ou realiza oposição governamental com a

${ }^{384}$ FIGUEIREDO, Argelina Cheibub; LIMONGI, Fernando. Executivo e Legislativo na Nova Ordem Constitucional. Rio de Janeiro: FGV, 1999, p. 144.

${ }^{385}$ FERREIRA FILHO, Manoel Gonçalves. Constituição e Governabilidade: ensaio sobre a (in)governabilidade brasileira. São Paulo: Saraiva, 1995, passim.

${ }^{386}$ FERREIRA FILHO, Manoel Gonçalves. A Disciplina Constitucional das Crises Econômico-financeiras. In: Revista de Informação Legislativa, Brasília, v. 27, n. 108, out./dez. 1990, pp. 33-48, pp. 40-46.

${ }^{387}$ FIGUEIREDO, Argelina Cheibub; LIMONGI, Fernando. Executivo e Legislativo na Nova Ordem Constitucional. Rio de Janeiro: FGV, 1999, p. 156.

${ }^{388}$ VICTOR, Sérgio Antônio Ferreira. Presidencialismo de coalizão: exame do atual sistema de governo brasileiro. São Paulo: Saraiva, 2015, p. 115. 
expectativa de ganhar a eleição presidencial no termo subsequente. ${ }^{389}$

Por outro lado, em relação ao orçamento público da União, a situação não apresenta alterações substanciais, pois os processos de elaboração, aprovação e execução orçamentários são bastante controlados pelo Poder Executivo, haja vista a plêiade de poderes políticos e jurídicos para o exercício rígido dessa dominância institucional. ${ }^{390}$

Assim, também nessa seara, "a principal linha de conflito do sistema político brasileiro não é dada pelas relações entre os poderes, mas sim pelas clivagens político-partidárias,"391 tendo em vista que na dinâmica governo-oposição o orçamento público tem como função precípua garantir o sucesso da política do governo, especialmente a econômica. Logo, as agendas orçamentárias do Executivo e do Legislativo não são conflitantes, mas complementares, uma vez que o governo "é capaz de canalizar as demandas dos parlamentares e acomodá-las no interior dos programas por ele definidos como prioritários. Ao executar emendas de parlamentares da oposição e/ou situação que não o apóiam, o Executivo está simplesmente executando sua agenda."392

Com essas considerações, reputa-se compreendida a dinâmica de relacionamento entre Executivo e Legislativo no plano orçamentário federal de abertura de créditos extraordinários por MP. Contudo, revela-se necessária a abordagem de três aspectos salientes da análise empreendida: a rejeição de MP pelo $\mathrm{CN}$ pela ausência dos requisitos de admissibilidade em duas oportunidades; o exercício parcial do poder de veto por parte do PR no momento da sanção; e a tramitação de emendas constitucionais com vistas a restringir a utilização de créditos extraordinários.

No tocante à inadmissão das MPs, verifica-se que não se trataram de reação legislativa ao Poder Executivo. Na verdade, pelo contrário. Na MP 430, de 14 de maio de 2008, a Câmara dos Deputados acolheu parecer pela inadmissão da MP por ausência dos requisitos de relevância e urgência, em sessão legislativa realizada no dia 10.07.2008, após sucessivos

\footnotetext{
${ }^{389}$ LIMONGI, Fernando. A Democracia no Brasil: presidencialismo, coalizão partidária e processo decisório. In: Novos Estudos, São Paulo, n. 76, nov. 2006, pp. 17-41, p. 41.

${ }^{390}$ Cf. PEREIRA, Carlos; MUELLER, Bernardo. Comportamento Estratégico em Presidencialismo de Coalizão: as relações entre Executivo e Legislativo na elaboração do orçamento brasileiro. In: Dados, Rio de Janeiro, v. 45, n. 2, 2002, pp. 265-301.

${ }^{391}$ LIMONGI, Fernando; FIGUEIREDO, Argelina. Processo Orçamentário e Comportamento Legislativo: emendas individuais, apoio ao executivo e programas de governo. In: Dados, Rio de Janeiro, v. 48, n. 4, pp. 737 776 , p. 766.

${ }^{392}$ LIMONGI, Fernando; FIGUEIREDO, Argelina. Processo Orçamentário e Comportamento Legislativo: emendas individuais, apoio ao executivo e programas de governo. In: Dados, Rio de Janeiro, v. 48, n. 4, pp. 737776 , p. 767.
} 
adiamentos, porquanto o valor do crédito extraordinário em questão já houvera sido aprovado por meio da Lei 11.734 , de $1^{\circ}$ de julho de $2008^{393}$, a qual autorizou a abertura de crédito adicional suplementar em favor do Ministério do Planejamento, Orçamento e Gestão no valor de $\mathrm{R}$ \$ 7,5 bilhões. Por conseguinte, observa-se aceitação por parte do $\mathrm{CN}$ do equívoco técnico e da irresponsabilidade política, ao se equiparar funcionalmente três tipos de créditos adicionais com finalidades e formalidades distintas, à luz de texto expresso da CR/88.

Por sua vez, em sessão legislativa realizada em 18.03.2011, o Senado Federal rejeitou a MP 508, de 08 de outubro de 2010, mediante acordo para não votação da matéria, uma vez que a Câmara dos Deputados a encaminhara a menos de duas sessões para a ocorrência da caducidade da MP, o que foi considerado período exíguo pelos senadores para exercício de seu mister constitucional. Nesse sentido, não houve impacto orçamentário, uma vez que a eficácia da norma já restaura exaurida e as relações jurídicas ocorridas à época restaram regidas pela MP, por força do art. $62, \S 11$, da CR/ $88^{394}$. Assim, a reação política não se deu em face do Poder Executivo, mas sim da Câmara dos Deputados ${ }^{395}$, na qualidade de primeira instância parlamentar de MP, ex vi art. 62, $\S 8^{\circ}$, da CR/88.

Em relação ao exercício do poder de veto por parte do Poder Executivo, observou-se sua utilização na MP 709, de 30 de dezembro de 2015, ao fundamento de inconstitucionalidade parcial do projeto de lei de conversão de MP aprovado no $\mathrm{CN}$, pois o art. 63, I, da CR/88, veda emenda parlamentar que implique em aumento de despesa prevista em projeto de iniciativa exclusiva do Presidente da República, ressalvadas as hipóteses do art. $166, \S \S 3^{\circ}$ e $4^{\circ}$ também do texto constitucional, o que teria ocorrido na espécie. Nesse sentido, as críticas relativas a uma blindagem constitucional à atividade parlamentar em âmbito orçamentário, já colocadas no Capítulo 1 desta pesquisa, também se aplicam à prática institucional dos créditos extraordinários.

Por fim, importa abordar PECs relativas à configuração constitucional dos créditos extraordinários. No âmbito do Senado Federal, a PEC 45/2008, que tem por primeiro signatário o Senador Flexa Ribeiro, possui o objetivo de alterar os arts. 85 e 167 da CR/88. A

\footnotetext{
${ }^{393}$ BRASIL. PRESIDÊNCIA DA REPÚBLICA. Lei 11.734, de 1 de julho de 2008. Abre ao Orçamento Fiscal da União, em favor do Ministério do Planejamento, Orçamento e Gestão, crédito suplementar no valor de R\$ 7.560.000.000,00, para reforço de dotação constant da Lei Orçamentária vigente, e dá outras providências. Diário Oficial da União, Brasília, Seção 1, Publ. em 02.07.2008, p. 1.

${ }^{394} \S 11$. Não editado o decreto legislativo a que se refere o $\S 3^{\circ}$ até sessenta dias após a rejeição ou perda de eficácia de medida provisória, as relações jurídicas constituídas e decorrentes de atos praticados durante sua vigência conservar-se-ão por ela regidas.

${ }^{395}$ BRASIL. SENADO FEDERAL. Diário do Senado Federal, Brasília, a. LXVI, n. 37, sessão de 18.03.2011, Publ. em 18.03.2011, p. 7238 e ss.
} 
primeira alteração pretendida no texto original era tornar hipótese de impeachment presidencial a edição de MP em desconformidade ao art. 62, §1 ${ }^{\circ}$, da CR/88. Ademais, a segunda alteração seria a modificação da redação do art. $167, \S 3^{\circ}$, da $\mathrm{CR} / 88$, para fins de tornar o rol de hipóteses autorizadoras de créditos extraordinários de exemplificativo para taxativo, de maneira a tornar possível a edição de MP para abertura de crédito extraordinário somente em casos de guerra, comoção interna ou calamidade pública.

Atualmente, a proposta encontra-se sob a análise da Comisão de Constituição e Justiça da referida casa legislativa, à espera de inclusão em pauta, tendo recebido parecer favorável em legislatura anterior do Senador Renato Casagrande em 2009, com emenda supressiva ao dispositivo que torna crime de responsabilidade a abertura de crédito extraordinário em hipótese incabível, e do Senador Álvaro Dias em 2011. Após requerimento do Senador Flexa Ribeiro, a PEC foi desarquivada e encontra-se, ainda, sob o crivo da Comisão de Constituição e Justiça.

Na Câmara dos Deputados, tramita a PEC 550/2006, cujo primeiro signatário é o Deputado federal Jutahy Junior, na qual estão apensadas as PECs 574/2006 e 102/2007, sendo que a inovação proposta ao texto constitucional é idêntica à apresentada no Senado Federal no que tange à sistemática dos créditos extraordinários, isto é, transformar as hipóteses autorizativas de créditos extraordinários em lista cerrada, embora as PECs da câmara baixa também disponham sobre emenda parlamentares individuais. De todo modo, já houve a apresentação de parecer favorável por parte do atual relator Deputado federal José Fogaça, então a proposta resta pronta para pauta na Comissão de Constituição e Justiça e de Cidadania da casa legislativa.

Em um esforço avaliativo relativo às PECs, cabem dois comentários. Em primeiro lugar, de fato, como anotou o Senador Renato Casagrande, era impróprio incluir no rol de crimes de responsabilidade da PR a abertura de crédito extraordinário em desacordo com o prescrito no art. $167, \S 3^{\circ}$, da $\mathrm{CR} / 88$, uma vez que já se trata de hipótese ensejadora de impeachment, claramente depreendida do art. 85, caput, e $\mathrm{VI}^{396}$, da CR/88, pois se trata de vedação constitucional expressa, assim como se depreender do termo "lei orçamentária" os créditos adicionais. Ademais, a conduta presidencial de abertura indevida de crédito

\footnotetext{
${ }^{396}$ Art. 85. São crimes de responsabilidade os atos do Presidente da República que atentem contra a Constituição Federal e, especialmente, contra: (...)VI - a lei orçamentária;
} 
extraordinário também é passível de tipificação nos arts. 10, IV $^{397}$, e 11, II ${ }^{398}$, da Lei 1.079/50, a qual define os crimes de responsabilidade e regula o respectivo processo de julgamento. Nesses termos, é preferível guiar-se pela estabilidade do texto constitucional em detrimento de certo "feitichismo constitucional"399.

Em segundo lugar, a despeito de ser uma rara e explícita conduta reativa do Poder Legislativo em face da edição reiterada de MPs por parte da PR, como se extrai da exposição de motivos das PECs, não se acredita que o quadro de violação sistemática à Constituição Financeira seja resolvido pela via semântica, mas sim pela pragmática da linguagem jurídica informada por uma "cultura constitucional" plausibilidade jurídica de que as referidas PECs, caso promulgadas, venham a representar mais um caso de constitucionalização simbólica em sentido negativo ${ }^{401}$ ou de reconstitucionalização simbólica permanente ${ }^{402}$ no âmbito da Constituição Financeira.

\subsubsection{O Poder Judiciário e a abertura de créditos extraordinários}

Com base na metodologia explicitada no Anexo D, pesquisou-se um órgão do Poder Judiciário (STF) e uma classe processual (ADI). Nesse escopo de investigação, a resultante foi 20 (vinte) AADDI, todas oriundas do Distrito Federal e ajuizadas por agremiações políticas com representante no $\mathrm{CN}$, nos termos do art. 103, VIII, da CR/88. De saída, constata-se ser assunto que exige a atenção do STF com alguma frequência.

\footnotetext{
397 Art. 10. São crimes de responsabilidade contra a lei orçamentária: (...) 4 - Infringir , patentemente, e de qualquer modo, dispositivo da lei orçamentária.

${ }^{398}$ Art. 11. São crimes contra a guarda e legal emprego dos dinheiros públicos: (...) 2 - Abrir crédito sem fundamento em lei ou sem as formalidades legais;

399 FEITOSA, Raymundo Juliano. O "feitichismo" como limite às possibilidades de concretização da Constituição Federal de 1988. In: SCAFF, Fernando Facury (org.). Constitucionalizando Direitos: 15 anos da constituição brasileira de 1988. Rio de Janeiro: Renovar, 2003, p. 242.

${ }^{400}$ Cf. VORLÄNDER, Hans. What is "Constitutional Culture"? In: HENSEL, Silke et al (ed.). Constitutional Cultures: on the concept and representation of constitutions in the atlantic world. Newcastle: Cambridge Scholars, 2012.

401 "Assim como a legislação simbólica, embora a constitucionalização simbólica seja caracterizada negativamente pela suência de concretização normativo-jurídica do texto constitucional, ela tem um sentido positivo, na medida em que a atividade constituinte e a linguagem constitucional desempenham um relevante papel político." (NEVES, Marcelo. Constitucionalização Simbólica. In: CANOTILHO, J. J. Gomes et al. Comentários à Constituição do Brasil. São Paulo: Saraiva/Almedina, 2013, p. 67)

${ }^{402}$ Nesse caso, os textos constitucionais são continuamente alterados, inspirados em retórica de reformismo constitucional, sem mudança relevante das correspondentes estruturas jurídicas e sociais. Cf. NEVES, Marcelo. Constitucionalização Simbólica. In: CANOTILHO, J. J. Gomes et al. Comentários à Constituição do Brasil. São Paulo: Saraiva/Almedina, 2013, p. 72.
} 
Ademais, é curioso o fato de todos os proponentes serem partidos políticos, bem como integrantes do bloco parlamentar da minoria no momento do ajuizamento. Desse modo, conclui-se que o controle abstrato de constitucionalidade foi incorporado à gramática de poder, de forma a representar uma arena alternativa de realização de oposição governamental, inclusive em seara orçamentária ${ }^{403}$. Nesse sentido, busca-se ao exercício da função contramajoritária de uma corte constitucional, consistente em fazer prevalecer a superioridade constitucional vis-à-vis maiorias eventuais. De qualquer sorte, em decorrência da concentração dos ajuizamentos dessas demandas em determinados momentos temporais, trata-se de uma estratégia de oposição legítima, mas errática, logo insuficiente para a manutenção da higidez do devido processo orçamentário.

Demais, o conjunto analisado corrobora a tese de uma ampla judicialização da política, para além dos processos de produção de políticas públicas, isto é, a judicialização da "política pura" (ou mega-política) traduzíveis em controvérsias políticas fulcrais que definem a organização política de uma sociedade. No particular, trata-se de uma subcategoria desse fenômeno: o escrutínio judicial das prerrogativas do Poder Executivo no manejo do planejamento macroeconômico ou da segurança nacional. $\mathrm{O}$ resultado desse processo seria a projeção de supremas cortes ao centro do aparato estatal no tocante às decisões políticas fundamentais. Noutras palavras, haveria uma "juristocracia" ou, no caso brasileiro, uma "Supremocracia" ${ }^{404}$, na qual as cúpulas judiciais tornam-se poderosos atores estratégicos na esfera pública democrática. ${ }^{405}$

Porém, no caso das MPs editadas para abertura de despesas que não são imprevisíveis ou urgentes, o STF “optou” por não exercer seu poder político na maior parte dos casos nos quais foi provocado, com efeito esses atos normativos exerceram seus efeitos jurídicos até perderem sua vigência, dada a sua temporariedade, representanto, por si só, subversão à ordem constitucional e respectiva força normativa.

No pensamento de Joaquim Falcão, “o Supremo seria um tribunal político não apenas porque concorda ou discorda do Executivo ou do Congresso. Mas antes porque controla o tempo de concordar ou discordar." ${ }^{406}$ Por conseguinte, a dimensão política da Justiça

\footnotetext{
${ }^{403}$ WALDRON, Jeremy. Principles of Legislation. In: BAUMAN, Richard W.; KAHANA, Tsvi (orgs.). The Least Examined Branch: the role of legislature in the Constitutional State. Nova York: Cambridge University Press, 2006, pp. 25-27.

${ }^{404}$ Cf. VIEIRA, Oscar Vilhena. Supremocracia. In: Direito GV, São Paulo, n. 4, v. 2, jul./dez. 2008, pp. 441-464.

${ }^{405}$ HIRSCHL, Ran. The New Constitutionalism and the Judicialization of Pure Politics Worldwide. In: Fordham Law Review, Nova York, v. 75, 2006-2007, pp. 721-753, p. 727.

${ }^{406}$ FALCÃO, Joaquim. O Supremo. Rio de Janeiro: Edições de Janeiro, 2015, p. 93.
} 
Constitucional não emana apenas da qualidade argumentativa de suas decisões, mas também de sua capacidade de estabilizar expectativas sociais em tempo hábil. Ou seja, o STF exercita seu papel político decisório, seja "como" decide (constitucional/inconstitucional), seja "quando" decide. Sendo assim no geral, com mais intensidade essa politização dúplice das decisões constitucionais faz-se constar em relação às leis orçamentárias, pois estas são temporárias e provisórias.

Em matéria de MP que abre crédito extraordinário, o STF decidiu por silenciar, ou melhor, paradoxalmente, não decidir, ao não julgar a maioria dos feitos pesquisados em tempo hábil, uma vez que o exaurimento da eficácia do crédito adicional (em geral, ânua) acarreta em prejudicialidade do processo de cunho abstrato, à luz da perda superveniente do objeto.

Essa situação representou 12 das 20 AADDI tratadas, sendo que em 10 (dez) delas sequer houve a apreciação da medida cautelar ${ }^{407}$. Em suma, na metade das ações ajuizadas para discutir violação direta à $\mathrm{CR} / 88$, ante suposto desvirtuamento da figura dos créditos extraordinários por parte da Chefia do Poder Executivo, o decurso do tempo inutilizou a jurisdição constitucional.

Aliás, é pouco sustentável a busca por corresponsáveis, como, por exemplo, os Requerentes, os Intimados, o AGU e o PGR, uma vez que incumbe ao juízo guardar a utilidade de seu provimento judicial, seja por meio da instrução e relatoria do feito (MinistroRelator), seja pela condução do julgamento em tempo hábil (Ministro-Presidente). Nesse sentido, há poderes processuais suficientes para o julgamento da ADI em tempo hábil, confiram-se, a propósito, os arts. $50, \S 2^{\mathrm{o}^{408}}$, e 52 , parágrafo único ${ }^{409}$, do RISTF, por sua vez recepcionado pela atual ordem constitucional com força e eficácia de lei. ${ }^{410} \mathrm{Na}$ verdade, somente 1 (uma) ADI não passou pelo escrutínio do órgão colegiado por negligência do Requerente, especificamente falta de aditamento da inicial, quando da conversão da MP em

\footnotetext{
${ }^{407}$ Em alguma medida, essa situação representa as disfuncionalidades atuais das medidas cautelares no controle abstrato de constitucionalidade: MENDES, Gilmar Ferreira; VALE, André Rufino do. Questões Atuais sobre as Medidas Cautelares no Controle Abstrato de Constitucionalidade. In: Observatório da Jurisdição Constitucional, Brasília, a. 5, 2011/2012, pp. 1-23.

${ }^{408}$ Art. 50. Sempre que couber ao Procurador-Geral manifestar-se, o Relator mandará abrir-lhe vista antes de pedir dia para julgamento ou passar os autos ao Revisor.

$\S 2^{\circ}$ Excedido o prazo, o Relator poderá requisitar os autos, facultando, se ainda oportuna, a posterior juntada do parecer.

${ }^{409}$ Parágrafo único. Salvo na ação penal originária ou nos inquéritos, poderá o Relator dispensar a vista ao Procurador-Geral quando houver urgência, ou quando sobre a matéria versada no processo já houver o Plenário firmado jurisprudência.

${ }^{410}$ BRASIL. SUPREMO TRIBUNAL FEDERAL. Vigésimo Sexto Agravo Regimental na Ação Penal 470, Plenário, Rel. Joaquim Barbosa, Rel. p/ Ac. Roberto Barroso, j. 18.09.2013, DJe Publ. em 17.02.2014.
} 
lei.

Porém, é necessário ressaltar que, em casos pontuais, o STF já excepcionou seu entendimento iterativo no sentido da prejudicialidade da ADI pelo exaurimento superveniente da eficácia de lei impugnada. ${ }^{411}$ Nesses casos, embora se constatasse a ausência de vigência da lei impugnada, julgou-se a ADI, porquanto houve (i) impugnação em tempo adequado, (ii) a ação foi incluída em pauta e (iii) seu julgamento foi iniciado antes do exaurimento da eficácia da lei orçamentária. Ressalva-se, ainda, que em nenhum desses casos referiu-se à abertura de crédito extraordinário por MP, bem como não se podem qualificar os critérios supracitados como cogentes, porquanto na ADI-MC-Ref 5.287 o Tribunal Pleno declarou prejudicada a demanda, mesmo com o preenchimento dos três requisitos. ${ }^{412}$ Nesse sentido, não se observa coerência normativa do STF na excepcionalização de sua jurisprudência, denotando certa arbitrariedade entre a reificação racionalista e o casuísmo irracionalista. ${ }^{413}$ Entretanto, trata-se de uma possibilidade dogmática para a suplantação do obstáculo temporal à prestação jurisdicional. ${ }^{414}$

Superada essa questão, a inefetividade da jurisdição constitucional também se faz presente em mais dois aspectos: a configuração normativa dos efeitos vinculantes em controle abstrato e concentrado de constitucionalidade; e por mecanismos de atuação direta dos Ministros sobre o processo político.

De acordo com o art. 102, $\S 2^{\text {o415 }}$, da CR/88, na redação dada pela EC 45/04, as

\footnotetext{
${ }^{411}$ Confiram-se, a propósito, os seguintes julgados: BRASIL. SUPREMO TRIBUNAL FEDERAL. Ação Direta de Inconstitucionalidade 4.426, Rel. Min. Dias Toffoli, Pleno, j. 09.02.2011, DJe Publ em. 17.05.2011; BRASIL. SUPREMO TRIBUNAL FEDERAL. Ação Direta de Inconstitucionalidade 3.146, Rel. Min. Joaquim Barbosa, Pleno, j. 11.05.2006, DJ Publ. em 19.12.2006, pp. 692-748; BRASIL. SUPREMO TRIBUNAL FEDERAL. Ação Direta de Inconstitucionalidade 5.287, Rel. Min. Luiz Fux, Pleno, j. 18.05.2016, DJ 106 Publ. em 24.05.2016 (extrato de ata).

${ }^{412}$ BRASIL. SUPREMO TRIBUNAL FEDERAL. Referendo em Medida Cautelar em Ação Direta de Inconstitucionalidade 4.663, Relatoria Ministro Luiz Fux, Tribunal Pleno, j. 15.10.2014, DJe 246, Publ. em 16.12.2014.

413 "O problema da jurisdição constitucional brasileira, nesses tempos de transição, parece ser: o judiciário nem vê o texto ontologicamente, como um ícone do objeto, e o vincula a uma interpretação pretensamente fixa (...) nem o concretiza por via de um projeto e de procedimentos hermenêuticos específicos. Tem os defeitos da reificação racionalista e os do casuísmo irracionalista: concepção reificadora, trato casuístico, uma esdrúxula incompatibilidade estratégica." (ADEODATO, João Maurício. Jurisidição Constitucional à Brasileira: Situação e Limites. In: SCAFF, Fernando Facury Scaff (org.). Constitucionalizando Direitos: 15 anos da Constituição Brasileira de 1988. Rio de Janeiro: Renovar, 2003, p. 96)

${ }^{414}$ Cf. MENDES, Gilmar Ferreira. A Doutrina Constitucional e o Controle de Constitucionalidade como Garantia da Cidadania. In: CLÉVE, Clemerson Merlin; BARROSO, Luís Roberto (orgs.). Doutrinas Essenciais Direito Constitucional: defesa da constituição. São Paulo: Revista dos Tribunais, 2011.

${ }^{415} \S 2^{\circ}$ As decisões definitivas de mérito, proferidas pelo Supremo Tribunal Federal, nas ações diretas de inconstitucionalidade e nas ações declaratórias de constitucionalidade produzirão eficácia contra todos e efeito vinculante, relativamente aos demais órgãos do Poder Judiciário e à administração pública direta e indireta, nas esferas federal, estadual e municipal.
} 
decisões definitivas de mérito em ADI e ADC produzem eficácia contra todos e vinculam aos demais órgãos do Poder Judiciário e à administração pública de todos os entes federativos. Segundo André Ramos Tavares, há três dimensões de efeitos emanadas das decisões em ADI: “i) via de regra, ex tunc (dimensão temporal); ii) eficácia erga omnes (dimensão subjetiva); e iii) efeito vinculante em relação ao Judiciário e à Administração Pública (dimensão institucional). ${ }^{, 416}$ Ressalta-se, ainda, que o Tribunal Pleno do STF deixou assente que a decisão concessiva de medida cautelar também implica em eficácia erga omnes e efeito vinculante. $^{417}$

Assim sendo, haure-se da dimensão institucional das decisões tomadas em ADI extensão tanto objetiva, quanto subjetiva. No tocante à extensão objetiva, pauta-se pela vinculatividade do assentado pelo STF perante os julgamentos futuros, enquanto a extensão subjetiva se traduz nos órgãos estatais serem obrigados a adotar o entendimento expresso pelo STF, em sede de ADI, no momento de aplicação do Direito. Logo, a extensão subjetiva do efeito vinculante não alcança o Poder Legislativo em sua função típica de elaboração e edição de leis. Desse modo, a jurisprudência do STF permite ao Poder legiferante editar diploma legal de conteúdo idêntico ao de outro diploma legislativo declarado inconstitucional, em sede de controle abstrato, assim como admite a possibilidade de o Poder Executivo sancionar projeto de lei cujo conteúdo possa estar em conflito com decisão em ADI. ${ }^{418}$

Na particularidade do presente objeto de pesquisa, a controvérsia relativa à extensão objetiva do efeito vinculante mostra-se relevante, uma vez que a jurisprudência atual do STF $^{419}$ e parcela da doutrina ${ }^{420}$ defendem que a vinculatividade somente atinge o dispositivo do processo objetivo (teoria restritiva), em que pese uma eficácia expansiva dos precedentes em sede de jurisdição constitucional. Por conseguinte, as dezenas de MPs editadas com o fito de abertura de crédito extraordinário no período de 2008-2015 deveriam ser impugnadas uma a uma, caso algum dos legitimados para a propositura de ADI entendesse pelo não atendimento dos requisitos da urgência e relevância da matéria, assim como da

\footnotetext{
${ }^{416}$ TAVARES, André Ramos. Curso de Direito Constitucional. 13 ed. São Paulo: Saraiva: 2015, p. 331.

417 BRASIL. SUPREMO TRIBUNAL FEDERAL. Reclamação 935, Pleno, Rel. Min. Gilmar Mendes, j. 28.04.2003, DJ Publ. em 17.10.2003; BRASIL. SUPREMO TRIBUNAL FEDERAL. Ação Direta de Inconstitucionalidade 4, Rel. Min. Sydney Sanches, Pleno, j. 11.02.1998, DJ Publ. em 21.05.1999.

${ }^{418}$ BRASIL. SUPREMO TRIBUNAL FEDERAL. Agravo Regimental em Reclamação 14.156, Rel. Min. Celso de Mello, Pleno, j. 19.02.2014, DJe 90 Publ. em 13.05.2014.

${ }^{419}$ Vide, inter alia: BRASIL. SUPREMO TRIBUNAL FEDERAL. Reclamação 3.014, Rel. Min. Ayres Britto, Pleno, j. 10.03.2010, DJe 91 Publ. em 21.05.2010; BRASIL. SUPREMO TRIBUNAL FEDERAL. Reclamação 8.168, Rel. Min. Ellen Gracie, Rel. p/ Ac. Min Edson Fachin, Pleno, j. 19.11.2015, DJe 37 Publ. em 29.02.2016.

${ }^{420}$ RAMOS, Elival da Silva. Controle de Constitucionalidade no Brasil: perspectivas de evolução. São Paulo: Saraiva, 2010, pp. 275-276.
} 
imprevisibilidade e urgência da despesa pública. Ademais, a ADI eventualmente interposta deveria ser processada e julgada em tempo hábil, tendo em conta a certeza do exaurimento da eficácia da lei orçamentária.

Noutra banda, ala minoritária no STF sustenta pela assunção da teoria dos motivos determinantes (teoria extensiva em maior ou menor medida) ${ }^{421}$, de modo que a extensão objetiva do efeito vinculante abarque as razões de decidir do colegiado. Assim, o ordenador de despesas estaria obrigado a atentar para os fundamentos determinantes da ADI antes de realizar o ato administrativo que lhe compete, com a garantia de interposição de reclamação constitucional, meio processual notadamente mais expedito, por um rol amplo de legitimados ad causam. Nesse sentido, sem pretensões generalizantes por se tratar de tema, per se, monográfico, parece-nos uma posição mais legítima (binômio eficiência-justiça), à luz do escopo da presente pesquisa.

Ademais, há um aparente problema acerca da extensão subjetiva do efeito vinculante, pois se verifica uma divergência reiterada e implícita entre o comportamento institucional do Poder Executivo, em função atípica legislativa, na edição de MP para abertura de créditos extraordinários e o majoritariamente assentado pelo Pleno do STF na ADI-MC 4.048. Na verdade, na esteira do pensamento de Luiz Guilherme Marinoni, há um conflito de separação de poderes na espécie, e não de efeito vinculante, porquanto o fato de os limites subjetivos não atingirem o Poder Legislativo (ou a legislação governamental) "não quer dizer que o legislador não tenha compromisso com as decisões do STF". ${ }^{422}$ Nesse sendeiro, a questão se resolve no plano dos diálogos constitucionais ${ }^{423}$ na medida em que é ônus argumentativo do Estado legiferante demonstrar a ausência de similitude fático-normativa ou a ocorrência de nova circunstância para justificar o discrímen entre o assentado em decisão definitiva de mérito em ADI e o novo diploma legal com conteúdo idêntico ao declarado inconstitucional. ${ }^{424}$

O segundo problema que implica em inefetividade da jurisdição constitucional quanto às impugnações em face da abertura de créditos extraordinários refere-se à "individualização"

\footnotetext{
${ }^{421}$ MENDES, Gilmar Ferreira; BRANCO, Paulo Gustavo Gonet. Curso de Direito Constitucional. 10 ed. São Paulo: Saraiva, 2015, pp. 1342-1345.

${ }^{422}$ MARINONI, Luiz Guilherme. Controle de Constitucionalidade. In: SARLET, Ingo Wolfgang; MARINONI, Luiz Guilherme; MITIDIERO, Daniel. Curso de Direito Constitucional. 4 ed. São Paulo: Saraiva, 2015, p. 1148. ${ }^{423}$ Cf. BRANDÃO, Rodrigo. Supremacia Judicial versus Diálogos Constitucionais: a quem cabe a última palavra sobre o sentido da Constituição? Rio de Janeiro: Lumen Juris, 2012.

${ }^{424}$ MARINONI, Luiz Guilherme. Controle de Constitucionalidade. In: SARLET, Ingo Wolfgang; MARINONI, Luiz Guilherme; MITIDIERO, Daniel. Curso de Direito Constitucional. 4 ed. São Paulo: Saraiva, 2015, pp. 1146-1149.
} 
ou "monocratização" do STF. Isso porque a autoridade da decisão do STF em ADI e da própria instituição depende da observância ao procedimento colegiado pelo qual se formam as convicções dos integrantes da Corte, as quais, por sua vez, formarão a posição do tribunal por meio da colheita e soma de votos individuais. Por isso, os arts. 10 e 22 da Lei 9.868/99 preconizam que, salvo em período de recesso forense, as medidas cautelares em ADI somente serão concedidas por decisão da maioria absoluta dos membros do Tribunal e se presentes na sessão pelo menos oito Ministros.

Nessa linha, Diego Werneck e Leandro Ribeiro sustentam que ao lado da prática decisória dos Ministros do STF no sentido de participarem do processo político nacional como parte de um colegiado judicial, passível de concepção como arena política de ação, diálogo e decisão, há formas de um Ministro influenciar processos políticos decisórios de âmbito nacional sem passar pelos procedimentos internos e colegiados do STF. A esse respeito, apresentam três poderes individuais dos Ministros: a antecipação de posições na imprensa, os pedidos de vista como controle individual da agenda da Corte e as decisões monocráticas como "jurisprudência pessoal". ${ }^{425}$ Para esta pesquisa, importam as decisões individuais pela possível divergência conteudística entre julgamentos monocráticos posteriores ao julgamento da ADI-MC 4.048.

Em relação à divergência, verifica-se que na ADI 4.904, de relatoria do Ministro Marco Aurélio, o Ministro Ricardo Lewandowski, em exercício da Presidência negou medida cautelar, em 25.01.2013 (período de recesso forense), por meio de decisão monocrática, a ser referendada pelo Tribunal Pleno, aos fundamentos de (i) não se extrair da ADI-MC 4.048 a vedação, de forma peremptória, da utilização dos créditos extraordinários pela PR; (ii) ser incabível ao Judiciário afastar a presença dos requisitos de relevância e urgência invocados pelo Executivo para edição de atos normativos com força de lei, sem empreender uma análise mais verticalizada da emergencialidade da despesa pública; e (iii) a situação descrita no feito configurar periculum in mora inverso, tendo em conta que a suspensão do ato poderia causar danos irreparáveis ou de difícil reparação.

Por outro lado, o Ministro Gilmar Mendes concedeu parcialmente medida cautelar pleiteada, em 30.04.2016, na ADI-MC 5.513, de sua relatoria, em decisão monocrática ad referendum do Pleno do STF, nos termos do art. 21, V, do RISTF, para fins de suspender a

\footnotetext{
${ }^{425}$ Cf. ARGUELHES, Diego Werneck; RIBEIRO, Leandro Molhano. O Supremo Individual: mecanismos de atuação direta dos Ministros sobre o processo político. In: Direito, Estado e Sociedade, Rio de janeiro, mn. 46, jan./jun. 2015, pp. 121-155.
} 
vigência de MP na parte em que abre crédito extraordinário em favor da PR, sob as rubricas de "Comunicação Institucional" (R\$ 85 milhões) e "Publicidade de Utilidade Pública" (R\$15 milhões). Nesse sentido, constatou-se a plausibilidade jurídica do pedido, por não parecer razoável a suposição de que gastos com publicidades sejam imprevisíveis e urgentes, bem como o periculum in mora, à luz de dano irreparável ao erário, pois uma vez aberto o crédito e realizadas as despesas, seria impossível recompor o status quo ante. Demais disso, o Ministro Relator destacou que não se discutia a conveniência e a oportunidade das despesas em questão, mas o dever do STF, como guardião da Constituição, em coibir violação direta à $\mathrm{CR} / 88$.

Para além de uma análise de compatibilidade ou divergência entre as referidas decisões, com possíveis conclusões relativas à observância obrigatória do STF aos seus próprios precedentes, constata-se que a monocratização do juízo decisório e a coexistência desses julgados sem decisão definitiva por parte do Tribunal Pleno levam ao enfraquecimento do desempenho deliberativo do STF no tocante à matéria, ao permitir que procedimentos endógenos influam nos processos políticos exógenos à Corte, sem a mediação do colegiado em composição plenária (principal instância deliberativa) em tempo razoável.

Assim, em retorno às tradições jurídicas legatárias de Theodor Viehweg, o estado da arte da sindicabilidade judicial em controle abstrato dos créditos extraordinários milita em favor de sua inconveniência política ${ }^{426}$, sob as luzes tanto da teoria da argumentação jurídica standard, quanto da retórica moderna, pois não há argumentação jurídica qualitativamente superior ou sequer encerramento adequado de cadeia argumentativa, a partir do silêncio ou do monólogo, recalcitrante ou não. ${ }^{427}$

Em suma, pelo menos no tocante à abertura de créditos extraordinários por MPs com o fito de fixar despesas públicas previsíveis e correntes, a tese de Carlos Bernal Pulido no sentido de que a proteção dos direitos fundamentais por parte da jurisdição constitucional (juristocracia) implicou em uma apropriada restrição ao hiperpresidencialismo na América

\footnotetext{
${ }^{426}$ Ver subseção 2.1.5 desta dissertação.

427 “A importância da jurisdição constitucional é, assim, crucial em um direito dogmaticamente organizado, pois o poder judiciário a constitui dirimindo lides que se originam de divergências sobre o próprio texto constitucional. O último plano para fixar o conteúdo específico de um texto constitucional e, por extensão, de qualquer outro texto normativo, transformando-os em norma jurídica, é do tribunal, dos juízes, pois são eles que eliminam a discutabilidade do conflito ao fazerem a coisa julgada.” (ADEODATO, João Maurício. Jurisidição Constitucional à Brasileira: Situação e Limites. In: SCAFF, Fernando Facury Scaff (org.). Constitucionalizando Direitos: 15 anos da Constituição Brasileira de 1988. Rio de Janeiro: Renovar, 2003, pp. 77-78).
} 
Latina não é verificada. ${ }^{428}$ Ao contrário. Pelas razões expostas, a jurisdição constitucional mostrou-se inefetiva para amenizar ou coibir a utilização abusiva e inconstitucional dos créditos extraordinários.

\subsection{Créditos Extraordinários, Hiperpresidencialismo e Democracia Delegativa}

Inicialmente, convém apresentar um balanço geral da atuação do Poder Executivo no processo de abertura de créditos extraordinários mediante MP no período de 2008-2015. O resultado alcançado não é muito distante do próprio texto constitucional vigente, o qual manteve um Poder Executivo presidencialista em muitos pontos similar ao produzido pelas reformas eficientistas do regime militar. É dizer: a CR/88 diferenciou-se significativamente da ordem anterior em relação à organização de direitos, porém manteve no essencial toda a organização dos Poderes estabelecida pela ditadura na Constituição da República de 1969. Posteriormente, a confluência das crises sociais internas e das influências externas em prol de programas neoliberais tornou o cenário favorável para o acúmulo de mais poder na autoridade presidencial. ${ }^{429}$ Nesse sentido, o Chefe do Poder Executivo da União exercitou, de fato, todos os poderes e faculdades que lhe foram imputados pela ordem constitucional, notadamente a atividade legiferante, nos moldes em que lhe é permitida. ${ }^{430}$

Esse fato, por si só, poderia qualificar o Brasil como uma República com sistema de governo disfuncional, o hiperpresidencialismo ${ }^{431}$, definível como um fenômeno caracterizado pela concentração de soberania no Presidente, além das competências fixadas pela Constituição, com o definhamento da divisão e do equilíbrio dos poderes e dos princípios da democracia constitucional.

\footnotetext{
428 Cf. PULIDO, Carlos Libardo Bernal. Direitos Fundamentais, Juristocracia Constitucional e Hiperpresidencialismo na América Latina. Trad. Graça Maria Borges de Freitas. In: Revista Jurídica da Presidência, Brasília, v. 17, n. 111, fev./maio 2016, pp. 15-34.

${ }^{429}$ GARGARELLA, Roberto. La Sala de Máquinas de la Constitución: dos siglos de constitucionalismo en América Latina (1810-2010). Buenos Aires: Katz, 2014, pp. 270-278.

${ }^{430}$ Embora haja ressalvas ao argumento de "normalidade institucional", veja-se a articulação de Fernando Limongi em razão de sua representatividade: "O fato é que o presidente brasileiro é poderoso do ponto de vista legislativo não porque usurpe o poder legislativo, mas porque a Constituição de 1988 assim o estabeleceu. $\mathrm{O}$ presidente tem a prerrogativa exclusiva de iniciar legislação nas principais áreas da política: tributação, orçamento e fixação dos quadros do funcionalismo, para citar as áreas fundamentais. Logo, o presidente não é um legislador qualquer." (LIMONGI, Fernando. A Democracia no Brasil: presidencialismo, coalizão partidária e processo decisório. In: Novos Estudos, São Paulo, n. 76, nov. 2006, pp. 17-41, p. 27)

431 Cf. NINO, Carlos Santiago. Fundamentos de Derecho Constitucional: análisis filosófico, jurídico y politológico de la práctica constitucional. Buenos Aires: Astrea de Alfredo y Ricardo Depalma, 1992.
} 
$\mathrm{Na}$ verdade, simultaneamente à ANC, Sérgio Abranches identificou que o dilema institucional brasileiro (necessidade de se encontrar um ordenamento institucional suficientemente eficiente para agregar e processar as pressões derivadas do sistema social), gerado pela heterogeneidade e pluralidade de interesses políticos concorrentes no âmbito da sociedade brasileira, geraria condições sócio-políticas para que o "presidencialismo de coalizão" fosse uma quase inevitabilidade dentro do contex to da ação governamental. ${ }^{432}$

Contudo, no plano orçamentário, foi impossível antecipar que a dinâmica do sistema de governo presidencial levaria a uma situação muito próxima ao que se apresentara no autoritarismo do regime militar, porquanto no curso de quase três décadas o Poder Executivo fez uso de uma série de estratégias e instrumentos políticos voltados a subtrair as novas prerrogativas parlamentares imaginadas na ANC e positivadas na CR/88 no campo do orçamento público. Nesse sentido, o poder de agenda característico do presidencialismo de coalizão, traduzível para o escopo da presente pesquisa nos poderes de iniciativa e execução do orçamento, garantiram ao governo um controle estrito da agenda orçamentária no período analisado, seja na definição dos temas substantivos a serem discutidos, seja na determinação do arcabouço procedimental para fins de tomada de decisões. Logo, na "nova solução orçamentária", restabeleceu-se o controle governamental sobre a orçamentação, mediante a ação sistemática do Poder Executivo federal em prol de manter inalterado o projeto de LOA remetido ao Legistativo e de obter o máximo de flexibilidade na execução das leis orçamentárias. $^{433}$

Ou seja, para além dos poderes de propor e executar o orçamento público, a PR atuou exitosamente no sentido de infirmar o exercício independente das funções constitucionais do $\mathrm{CN}$, notadamente os poderes de elaborar e aprovar as leis orçamentárias, por meio de instrumentos variados, sendo parcela deles constitucionalmente previstos para fins emergenciais, como é o caso dos créditos extraordinários. Nesse quadro de abusividade constitucional, o desempenho institucional do STF mostrou-se pouco eficaz para guardar a

\footnotetext{
432 "Em síntese, a estrutura econômica alcançou substancial diversidade e grande complexidade; a estrutura social tornou-se mais diferenciada, adquiriu maior densidade organizacional, persistindo, porém, grandes descontinuidades, marcada heterogeneidade e profundas desigualdades. Daí resultaram maiores amplitude e pluralidade de interesses, acentuando a competitividade e o antagonismo e alargando o escopo do conflito, em todas as suas dimensões. Ao mesmo tempo, o Estado cresceu e burocratizou-se e a organização política seguiu estreita e incapaz de processar institucionalmente toda essa diversidade, de agregar e expressar com eficácia e regularidade a pluralidade de interesses e valores." (ABRANCHES, Sérgio Henrique Hudson de. Presidencialismo de coalizão: o dilema institucional brasileiro. In: Dados, rio de Janeiro, v. 31, n. 1, 1988, pp. 534 , p. 7)

${ }^{433}$ ROCHA, Antonio Sérgio Carvalho. As Partes e o Todo: congresso nacional, executivo e o problema do orçamento no Brasil. In: Perspectivas, São Paulo, v. 34, jul.dez. 2008, pp. 55-78, pp. 69-70.
} 
ordem constitucional vigente ou mesmo para fins de observância de sua jurisprudência por parte do Poder Público.

Assim sendo, no tocante à abertura de créditos extraordinários, um diagnóstico plausível pressupõe alguma forma de regime "híbrido" de governo que se traduz em uma gradiente entre o autoritarismo e a democracia, portanto combinam-se alguns aspectos democráticos com outros autocráticos. Nesse sentido, há eleições periódicas e relativamente livres nas quais representantes são democraticamente eleitos, de modo que esse tipo de autoritarismo marca-se pela competitividade dos grupos políticos pelo controle das instituições formais, as quais são o principal meio de obtenção e exercício da autoridade política. Se por um lado o sistema eleitoral abarca as vantagens internas e internacionais dessa opção democrática, de outro os atores políticos dominantes utilizam-se do constitucionalismo para violar regras democráticas formais pré-estabelecidas, com a finalidade de manter sua hegemonia e reduzir possíveis contestações internas nas arenas eleitoral, legislativa, judiciária e midiática. ${ }^{434}$

Nesse sentido, identifica-se uma prática de constitucionalismo abusivo na medida em que os atores políticos se utilizam de mecanismos de mudança constitucional de índoles formal e informal para tornar uma organização política estatal significativamente menos democrática. A resultante é a permanência dos grupos políticos no poder e a distorção dos mecanismos de accountability vertical, considerando o Estado como uma rede de relações de poder institucionalizadas. ${ }^{435}$

Com espeque em uma tipologia da democracia, Guillermo O’Donnell identificou esse contexto como "democracia delegativa", baseada na premissa de que aquele "que ganha uma eleição é autorizado a governar o país como lhe parece conveniente e, na medida em que as relações de poder existentes permitam, até o final de seu mandato." ${ }^{436}$ Nesse sentido, a ideia de representação envolve um elemento de delegação mediante a qual o representante se vê autorizado a falar em nome dos representados. Logo, a accountability em sua direção vertical (governante-governado) é satisfeita em níveis razoáveis, ao passo que a dimensão horizontal (rede de poderes relativamente autônomos) da prestação de contas possui nenhuma ou pouca

${ }^{434}$ Cf. LEVITSKY, Steven; WAY, Lucan A. The Rise of Competitive Authoritarianism. In: Journal of Democracy, Washington-DC, v. 13, n. 2, abr. 2002, pp. 51-65. Confira-se também: TUSHNET, Mark. Authoritarian Constitutionalism. In: Cornell Law Review, Ithaca-EUA, v. 100, 2014-2015, pp. 391-461.

${ }^{435}$ LANDAU, David. Abusive Constitutionalism. In: University of California Davis Law Review, Davis-EUA, v. 47, 2013-2014, pp. 189-260, p. 199-200.

${ }^{436}$ O’DONNEL, Guillermo. Democracia Delegativa? In: Novos Estudos, São Paulo, n. 31, out. 1991, pp. 25-40, p. 30. 
obrigatoriedade. Isso porque o "governo pela emergência"437 permite o decretismo (alto número de decisões tomadas unilateralmente e rapidamente por instâncias governamentais e tecnocráticas), haja vista que, no polo oposto, o processo decisório no tocante às políticas públicas na democracia representativa é lenta e incremental. ${ }^{438}$

A despeito de ter como referência a experiência norte-americana, por possuir alto grau explicativo para a situação da abertura de créditos extraordinários no Brasil, recorre-se à doutrina de Sanford Levinson e Jack Balkin acerca do "governo por meio da emergência", segundo a qual as seguintes características podem ser delineadas desse paradigma governamental: a distribuição de poderes ditatoriais nos vários níveis burocráticos; a habilidade presencial de criar uma realidade política emergencial; um esquema ponzi (piramidal) presidencial; e certa esquizofrenia presidencial com matiz de democracia plebiscitária. ${ }^{439}$

Em relação ao primeiro aspecto, tem-se um contraponto à tentativa de identificar a concentração de poder na figura presidencial, porquanto há uma dispersão quase inevitável de poderes pelo aparato estatal de cunho tecnocrático, porque as questões políticas em um Estado administrativo exigem variadas áreas de expertise, a depender da crise a ser enfrentada. Logo, há uma delegação vertical de poderes no âmbito governamental, o que torna impraticável um controle efetivo do presidente em relação às decisões discricionárias tomadas em esferas inferiores de governo. Em síntese, "O presidente e sua equipe pessoal são o alfa e o ômega da política (...) Os técnicos, especialmente em política econômica, devem ser protegidos politicamente pelo presidente contra as múltiplas resistências da sociedade" ${ }^{\text {"40 }}$.

Esse aspecto do presidencialismo brasileiro foi perceptível na presente pesquisa, porquanto a exposição de motivos enviada pelo Ministro do Planejamento, Gestão e Orçamento é adotada na íntegra pela PR, inclusive em relação à caracterização de uma situação de imprevisibilidade e urgência da despesa pública. Ademais, no plano da execução orçamentária, há importante decisão discricionária acerca do cancelamento de despesa programada e aprovada pelo Poder Legislativo para gerar lastro financeiro para o crédito

\footnotetext{
437 LEVINSON, Sanford; BALKIN, Jack M. Constitutional Dictatorship: Its Dangers and Its Design. In: Minnesota Law Review, Minneapolis-EUA, v. 94, 2009-2010, pp. 1789-1866, p. 1843 e ss.

${ }^{438}$ Cf. O’DONNEL, Guillermo. Democracia Delegativa? In: Novos Estudos, São Paulo, n. 31, out. 1991, pp. 2540.

439 LEVINSON, Sanford; BALKIN, Jack M. Constitutional Dictatorship: Its Dangers and Its Design. In: Minnesota Law Review, Minneapolis-EUA, v. 94, 2009-2010, pp. 1789-1866, p. 1840 e ss.

${ }^{440}$ O’DONNEL, Guillermo. Democracia Delegativa? In: Novos Estudos, São Paulo, n. 31, out. 1991, pp. 25-40, p. 31 .
} 
extraordinário, sem maiores possibilidades de escrutínio parlamentar ou popular.

No tocante ao segundo e ao terceiro aspectos, a legitimidade da utilização reiterada de poderes emergenciais por parte do presidente depende da capacidade deste em convencer sobre a natureza e o escopo da situação crítica perante o país. Assim, a existência de uma crise, com a respectiva utilização de poderes emergenciais, permite ao governo controlar a agenda política, a imaginação política nacional e nulificar a atuação da oposição. Logo, o incentivo à formação de um esquema ponzi (piramidal) é considerável, uma vez que se torna vital substituir uma crise por outra periodicamente ${ }^{441}$ com o fito de manter o apoio e a atenção popular para o projeto de poder governamental. ${ }^{442}$

Nesse ponto, a inexistência de maiores resistências legislativas ou judiciais à utilização reiterada de créditos extraordinários para viabilizar despesas correntes ou de capital previsíveis demonstra a capacidade da PR em criar a realidade fiscal para a execução de suas obras e projetos, ainda que sem base financeira para tanto. De novo com base na heterogeneidade e pluralidade de interesses sociais, torna-se simples e rotineiro criar espaço fiscal para gastos públicos arbitrados unicamente pelo Poder Executivo já no curso da execução orçamentária, haja vista a capacidade institucional demonstrada na pesquisa em gerar periodicamente situações "imprevisíveis" e "emergenciais" nas mais variadas funções de Estado.

Em relação ao componente plebiscitário do presidencialismo e respectiva esquizofrenia, uma possibilidade explicativa acerca da dinâmica do sistema constitucional no qual há um Executivo hipertrofiado, um Legislativo enfraquecido e um Judiciário impotente é o caráter delegativo da representação dos governados pelo governante. Nesse sentido, o presidente não apenas fixa a agenda legislativa, mas também personifica o sentimento popular, a partir de valores, aspirações e esperanças, notadamente em períodos de crises

\footnotetext{
${ }^{441}$ Sobre o caso brasileiro pós-constituinte, veja-se: "Em terceiro lugar, mas não menos importante, essa maneira peculiar de engessar as disputas leva também o debate público a uma espécie de círculo enlouquecido. Como as margens de manobra são muito estreitas, os 'suspeitos de sempre' desse típico clinch político brasileiro aparecem e reaparecem periodicamente. A legislação trabalhista é o grande problema em março e abril, a reforma política é o tema de maio e junho, a previdência toma julho e agosto e setembro e outubro são meses de reforma tributária. E assim por diante.

Não estou querendo dizer que esses problemas não sejam reais. Quero apenas chamar a atenção para essa espécie de 'coerção à repetição' que nunca vai às causas. É uma ilusão achar que não se avança nessas ditas reformas porque "não há vontade política'." (NOBRE, Marcos. Indeterminação e Estabilidade. In: Novos Estudos, São Paulo, n. 82, nov. 2008, pp. 97-106, p. 102)

${ }^{442}$ LEVINSON, Sanford; BALKIN, Jack M. Constitutional Dictatorship: Its Dangers and Its Design. In: Minnesota Law Review, Minneapolis-EUA, v. 94, 2009-2010, pp. 1789-1866, pp. 1843-1851.
} 
econômica e social. ${ }^{443}$

Nesses termos, há uma forte tendência a um governo de salvadores (salvação nacional ou da pátria), pois "leva a um estilo mágico de elaboração de políticas: o 'mandato' delegativo para governar supostamente emanado da maioria, forte vontade política e um conhecimento técnico apropriado seriam suficientes para cumprir a missão do salvador". ${ }^{44}$

Aliás, a esquizofrenia decorreria justamente da incompatibilidade teórica do que ocorre na prática constitucional, isto é, uma desconexão prolongada em contextos emergenciais entre o presidencialismo plebiscitário, caracterizado pelo culto ao líder carismático, e o departamentalismo dos poderes decisórios, marcado pela difusão e desconcentração da tomada de decisões entre instituições e indivíduos anônimos ao grande público, logo providos de legitimidade técnica, e não democrática, para encontrar soluções pragmáticas às situações críticas. ${ }^{445}$

No campo da abertura de créditos extraordinários no Brasil, o baixo apelo midiático e a ausência de mecanismos para o engajamento cívico ${ }^{446}$ em questões relativas ao orçamento público facilitam o desenvolvimento desse aspecto autoritário do sistema de governo brasileiro, sem maior conscientização social ou reações políticas das escolhas alocativas tomadas, o que, para o campo jurídico, significa a opção governamental pelo grau de efetividade de cada um dos direitos fundamentais previstos na $\mathrm{CR} / 88$, nos limites do financeiramente possível e da qualidade do gasto público.

Em suma, a chave analítica extraída da categoria "democracia delegativa" permite um diagnóstico com acurácia satisfatória ao escopo da pesquisa em relação à abertura de créditos extraordinários mediante MP, porquanto o componente delegativo da democracia representativa brasileira permite à PR manipular conceitos constitucionais e instrumentos orçamentários, em consonância à conveniência e oportunidade do governo perante a situação conjuntural do ambiente político, sem maiores responsabilizações pelo abuso institucional, ante a baixa obrigatoriedade da accountability horizontal, assim como o presidencialismo plebiscitário, concentrado em momento eleitoral, que, por sua vez, distorce a percepção social

\footnotetext{
${ }^{443}$ LEVINSON, Sanford; BALKIN, Jack M. Constitutional Dictatorship: Its Dangers and Its Design. In: Minnesota Law Review, Minneapolis-EUA, v. 94, 2009-2010, pp. 1789-1866, p. 1855.

${ }^{444}$ O’DONNEL, Guillermo. Democracia Delegativa? In: Novos Estudos, São Paulo, n. 31, out. 1991, pp. 25-40, p. 36.

${ }^{445}$ LEVINSON, Sanford; BALKIN, Jack M. Constitutional Dictatorship: Its Dangers and Its Design. In: Minnesota Law Review, Minneapolis-EUA, v. 94, 2009-2010, pp. 1789-1866, p. 1855.

${ }^{446}$ REUBEN, William. The Role of Civic Engagement and Social Accountability in the Governance Equation. In: Social Development Notes, Washington-DC, n. 75, mar. 2003, pp. 1-4.
} 
em relação ao manejo governamental do ciclo orçamentário, sob as luzes do accountability vertical.

Conclui-se, portanto, que a faculdade de abrir créditos extraordinários por MP representa mais uma vantagem estratégica na orçamentação conferida ao Poder Executivo e à coalizão partidária governante, em prejuízo do dever de prestar contas em direção horizontal e do preconizado na Constituição da República de 1988. 


\section{CONCLUSÃO}

De saída, ressalta-se que o presente movimento conclusivo espelha-se na introdução ao presente trabalho, pois busca aclarar os questionamentos ali realizados. Logo, reputa-se verificada a hipótese principal vocalizada nesta pesquisa, segundo a qual a utilização na ordem de dezenas de vezes de créditos extraordinários abertos mediante MP no âmbito federal entre 2008 e 2015 representou uma ofensa sistêmica à dimensão financeira da CR/88.

Para chegar-se a essa conclusão, construiu-se um perfil constitucional referente ao orçamento público para fins de avaliação da conduta estatal no ciclo orçamentário. Nesse sentido, articulou-se os elementos essenciais de um Estado Constitucional e respectivos reflexos na atividade financeira do ente público, principalmente mediante a explicitação das tensões produtivas decorrentes da interação entre o constitucionalismo e a democracia no fenômeno financeiro.

Delineado esse panorama, partiu-se para o escopo particular do regime constitucional do orçamento público. Definiu-se esta invenção social estruturante do Estado como a lei que estabelece a unidade da atividade financeira estatal, por meio da qual se concretizam os fins da ordem constitucional e para qual convergem as ações estatais viabilizadas pela dinâmica entre receitas, despesas e créditos públicos.

Ainda nesse tópico, concentrou-se no aspecto jurídico do orçamento público com o fito de estabelecer as condições de possibilidade e os limites da vinculatividade da orçamentação. Por conseguinte, superou-se o duplo conceito da lei orçamentária, representado nas perspectivas formal e material, para imputar substancialidade ao diploma legal por derivação direta da Constituição, ante a passagem do Estado Liberal para o Social e a adoção do presidencialismo republicano.

Ou seja, qualificou-se o orçamento público como lei em sentidos material e formal, não só pela observância dos procedimentos deliberativos em processo legislativo qualificado, mas também pelos efeitos jurídicos de vinculação do Poder Público, pois este deve observar as possibilidades deônticas para a conduta social hauridas dos dispositivos orçamentários, mesmo que não haja um dever de gastar recursos públicos de maneira impositiva.

Passadas essas considerações de ordem teórica, abordou-se o orçamento público como posto na $\mathrm{CR} / 88$, sem desconsiderar a historicidade do processo político que lhe oportunizou. A propósito, entendeu-se a ANC e o período de redemocratização como eventos singulares na 
história brasileira, na medida em que houve intensa participação cívica e ausência de um bloco hegemônico de poder com capacidade prévia de impor as condições e o escopo da disputa política em momento constitucional. Nesse campo, focalizou-se no tratamento dispensado às finanças públicas em geral e à orçamentação em particular, sobretudo no que se denominou "problema do orçamento" que se resolve por intermédio de um arranjo constitucional entre os Poderes Executivo e Legislativo, à luz de uma dicotomia entre a eficiência macroeconômica e a participação parlamentar em seara orçamentária.

Então, revelou-se claro no processo constituinte, especialmente nos debates travados na Comissão do Sistema Tributário, Orçamento e Finanças da ANC, o intuito de não repetir a “solução populista” observada no período de 1946-1963, em razão da inviabilidade de mínima integridade da lei orçamentária a partir de uma intervenção ampla e irrestrita do Legislativo, nem a "solução autoritária" vigente no período de 1964-1984, por conta do alijamento do Congresso Nacional do processo orçamentário em prol de uma racionalidade macroeconômica que seria obtida mediante o tecnicismo das burocracias do governo central.

Ademais, ambos os aspectos da singularidade histórica do processo constituinte não se fizeram intensos no bojo da referida Comissão e temáticas constitucionais a que se pretendia tratar, pois a orçamentação foi objeto de atenção de um grupo reduzido de parlamentares constituintes os quais não tinham entre si múltiplas divergências substantivas acerca da redação dos diversos anteprojetos e substitutivos relacionados ao orçamento público.

De maneira curta e direta, três foram as preocupações dos constituintes em relação ao tema do orçamento público: (i) a reunificação orçamentária; (ii) o restabelecimento do planejamento de médio prazo na Administração Pública; e (iii) a recuperação de prerrogativas do Poder Legislativo para elaboração do orçamento e fiscalização de sua execução. Em relação ao último quesito, a "nova solução do orçamento" se traduziu em um Poder Legislativo, ainda, com limitada influência na fixação de despesas públicas, mas com a possibilidade de fixação de prioridades do setor público mediante macroalocações orçamentárias e consideráveis poderes na fiscalização da execução do orçamento.

No decorrer da vigência da $\mathrm{CR} / 88$, observou-se dois elementos políticos não devidamente equacionados no processo constituinte. Por um lado, a multiplicação de demandas e o engessamento dos acordos conseguidos em momento constitucional, de modo que o essencial do orçamento público foi constitucionalizado, retirando parcela expressiva dos recursos públicos das disputas políticas posteriores. Por outro lado, a afirmação institucional 
do Poder Judiciário como ator político e por efeito, a judicialização da política.

Após esse expediente histórico, passou-se a importar a Constituição Financeira positivada na $\mathrm{CR} / 88$, sendo que a argumentação se centrou especificamente em torno dos artigos 163 a 169 da $\mathrm{CR} / 88$, os quais se referem às normas gerais de finanças públicas e ao orçamento público. Em termos normativos, descreveu-se o sistema orçamentário nacional, sobretudo no que toca aos princípios e regras do orçamento público acolhidos em plano constitucional e às estruturas, finalidades e identidades das leis orçamentárias (LOA, LDO, PPA e créditos adicionais). Chegou-se, portanto, ao seguinte parâmetro de correção material da conduta estatal: os créditos adicionais (suplementares, especiais e extraordinários) devem ser considerados instrumentos adjetivos e residuais à orçamentação, cuja função precípua é adaptar o planejado à realidade fiscal.

Na segunda parte da dissertação, intentou-se responder se a construção jurisprudencial do STF a respeito do controle abstrato de constitucionalidade das normas orçamentárias mostrou-se adequada e coerente em nível de argumentação jurídica. Aportou-se uma resposta afirmativa, ao fundamento de que se faz possível a justiciabilidade de decisões orçamentárias vertidas em teses de índole constitucional formuladas em abstrato no âmbito da competência originária do STF.

Nesse ponto, iniciou-se esse esforço investigativo com a formulação teórica desenvolvida por Theodor Viehweg referente à Tópica Moderna. Com base nisso, fez-se uma diferenciação entre dois eixos das teorias do discurso jurídico, a Retórica moderna da Escola de Mainz e a Teoria da argumentação jurídica standard com referencial teórico em Neil MacCormick e Robert Alexy. Assim, foi possível averiguar a possibilidade e a conveniência de arranjos institucionais que possibilitem a produção de discursos jurídicos racionais e adequados na seara da jurisdição constitucional às exigências democráticas.

Para a corrente retórica, a viabilidade democrática de uma corte constitucional advém da constrição da decisão (non liquet), de modo que se trata de uma instância decisória responsável pelo encerramento, mesmo que provisório e situacional, de uma cadeia argumentativa relativa a um tópico juridicamente relevante. Noutra banda, segundo a corrente da argumentação padrão, a jurisdição constitucional é o elo entre a teoria da argumentação jurídica e a dos direitos fundamentais, logo a instituição revela-se conveniente na medida em que consegue vincular racionalmente uma argumentação qualitativa acerca dos direitos fundamentais a uma decisão jurídica dotada de cogência. 
A partir dessas considerações propedêuticas, tornou-se cabível traçar estratégias metodológicas para a análise de discursos judiciais do STF; por sua vez aquelas foram aplicadas à narrativa jurisprudencial acerca do controle objetivo de normas orçamentárias, principalmente com o objetivo de examinar a decisão tomada na ADI-MC 4.048, de relatoria do Ministro Gilmar Mendes, com julgamento findo em 14 de maio de 2008.

Com referência no marco teórico formulado a partir de Neil MacCormick, avaliou-se de forma positiva essa decisão em termos de coesão, coerência e consequências jurídicas em relação ao ordenamento jurídico no geral e à cadeia de precedentes sobre a cognoscibilidade de demanda em abstrato deduzida em face de lei de orçamento público no particular.

Igualmente, realizou-se uma análise empírico-retórica da decisão. Nesse escopo, descobriu-se uma alta incidência de argumentos relativos ao ethos da Corte, significando uma disputa no colegiado acerca da significância da afirmação política do Poder Judiciário frente aos demais Poderes para controlar e influir na política fiscal da União. Além disso, em relação à dimensão do pathos, observou-se que a intensidade e a relevância do papel das emoções foram notáveis no processo decisório, mesmo se tratando de tese formulada em abstrato em matéria de Direito Financeiro. Por outro lado, a baixa incidência de argumentos atinentes ao logos reflete, em alguma medida no âmbito do Tribunal Pleno do STF, a premissa de exclusão da práxis jurídica de parcela significativa do conceito analítico do orçamento púbico.

De todo modo, em fecho à segunda parte da dissertação, articulou-se pela justiciabilidade em abstrato da abertura de créditos extraordinários mediante MP, haja vista que se mostrou necessária atuação da jurisdição constitucional perante hipóteses de inexecução reiterada em ofensa à normatividade da $\mathrm{CR} / 88$, para fins de estabilização das expectativas dos mais diversos setores sociais em relação ao orçamento público.

No início da última parte da dissertação, trabalhou-se a categoria jurídica dos poderes de emergência para lidar com crises constitucionais, especialmente de índole econômicofinanceira, de modo a constatar a persistência e iteratividade de seu uso na tradição pública ocidental como problema estruturante do constitucionalismo. Com amparo nessa problemática, tratou-se da realidade empírica da abertura dos créditos extraordinários por meio de MPs entre 2008 e 2015 no contexto da União.

Por meio de análises quantitativa e qualitativa da atuação do Poder Executivo federal, constatou-se uma banalização do regime excepcional dos créditos adicionais extraordinários, uma vez que estes representaram R \$ 270,3 bilhões e 51 em um universo de 289 MPs editadas 
no período analisado. Logo, mostraram-se elevadas taxas de sucesso e dominância governamental no escopo desse instrumento orçamentário de cunho emergencial. Ou seja, confirmou-se a hipótese principal da pesquisa em termos de periodicidade e impacto fiscal. Com base nisso, afirmou-se que o manejo governamental do ciclo orçamentário opera em um paradigma de governo no qual a "emergência" é programada, à luz da relevância dos créditos extraordinários em cotejo aos planos orçamentários globalmente considerados.

Observou-se, ainda, um desempenho institucional do Poder Legislativo da União dependente do governo, de modo que não há divergência qualitativa ao observado na interação genérica entre Executivo e Legislativo. Nessa linha de raciocínio, o primeiro detém ascendência sobre o segundo mediante o poder de agenda em duplo sentido, reconhecimento de problemas políticos a serem solucionados e criação de propostas políticas para a solução desses. Assim, a PR controla tanto a pauta de propostas submetidas ao $\mathrm{CN}$, quanto a oportunidade em que essa agenda será apreciada.

Dentro desse panorama compreensivo, foram também examinadas três hipóteses específicas de relacionamento entre os dois Poderes. Em primeiro lugar, notou-se que a rejeição de MP pelo $\mathrm{CN}$ em razão da ausência dos requisitos de admissibilidade não é utilizada como instrumento reativo ao Executivo. Demais, a PR utiliza-se do poder de veto na hipótese de ocorrência de emenda parlamentar na qual conste inovação temática que se traduz em imputação de destinação orçamentária diversa em relação à proposta original encaminhada. Enfim, verificou-se a existência de um conjunto de PECs em ambas as casas legislativas da esfera federal tendentes a alterar o rol de hipóteses autorizadoras de crédtos extraordinários de exemplificativo para taxativo. Nada obstante se trate de episódio de reação legislativa ao manejo abusivo dos créditos extraordinários pelas instâncias governamentais, creditou-se baixa probabilidade de conversão das propostas em emenda constitucional e questionou-se a efetividade da medida constitucional para sanar as disfuncionalidades a que se propõe.

Em relação ao desempenho institucional do STF, após os julgamentos das medidas cautelares em ADI 4.048 e 4.049, anota-se inefetividade da jurisdição constitucional para amenizar ou coibir a utilização dos créditos extraordinários em hipóteses inconstitucionais. A partir do exame das 20 AADDI ajuizadas em face de MP que veicule a abertura de crédito extraordinário, concui-se que as razões desse baixo desempenho são: (i) o obstáculo temporal à prestação jurisdicional, uma vez que a lei orçamentária tem sua eficácia temporária a qual se mostrou um lapso de tempo menor do que aquele necessário para processar e julgar a ADI; 
(ii) a configuração normativa dos efeitos vinculantes em controle abstrato e concentrado de constitucionalidade, uma vez que não impedem o descumprimento reiterado da jurisprudência do STF; e (iii) os mecanismos de atuação direta dos Ministros sobre o processo político sem mediação da instância deliberativa colegiada, os quais geram a coexistência de entendimentos divergentes proferidos em decisões monocráticas ad referendum do Pleno, mesmo depois do julgamento da ADI-MC 4.048.

Ante esse quadro, constata-se que para além dos poderes de propor e executar o orçamento público, o Poder Executivo atuou exitosamente no sentido de infirmar o exercício independente das funções constitucionais do Poder Legislativo, notadamente os poderes de elaborar e aprovar as leis orçamentárias, por meio de instrumentos variados, sendo parcela deles constitucionalmente previstos para fins emergenciais, como é o caso dos créditos extraordinários. Nesse quadro de abusividade constitucional, o desempenho institucional do Poder Judiciário mostrou-se pouco eficaz para guardar a ordem constitucional vigente ou mesmo para fins de observância de sua jurisprudência por parte do Poder Público. Há, portanto, uma distorção da accountability vertical, isto é, o dever de prestar constas aos demais Poderes constituídos possui nenhuma ou pouca obrigatoriedade vis-à-vis ao decretismo governamental.

De fato, o componente delegativo da democracia representativa brasileira permitiu a manipulação de conceitos constitucionais e instrumentos orçamentários por parte da PR, em consonância à conveniência e oportunidade do governo perante a situação conjuntural do ambiente político, tachada arbitrariamente de "emergência constitucional", sem maiores responsabilizações institucionais. Concluiu-se, ao fim e ao cabo, que a faculdade de abertura de créditos extraordinários por MP representa uma vantagem estratégica na orçamentação pública conferida ao Poder Executivo e à coalizão partidária governante, em detrimento do dever de prestar contas em direção horizontal e do preconizado na CR/88.

Assim sendo, considera-se respondida a problemática vocalizada em introdução e desdobrada na presente pesquisa, à luz das balizas metodológicas adotadas. Igualmente, reputam-se atingidos ambos os objetivos da dissertação. Por um lado, espera-se ter explorado e aclarado alguns aspectos do regime constitucional da atividade financeira do Estado, colocando em evidência a importância do orçamento público para o constitucionalismo, sobretudo no financiamento de direitos fundamentais e na divisão funcional dos poderes. Noutra banda, acredita-se que este trabalho serve à compreensão da dinâmica empírica da organização jurídico-política do Estado brasileiro, sob a égide da CR/88, em seara 
orçamentária. Portanto, trata-se de contributo para evidenciar o contorno fático-normativo do orçamento público no Brasil e respectivo manejo cíclico, assim como para informar eventuais reformas normativas e institucionais, de índole formal ou não, com vistas a amenizar ou solucionar os déficits constitucionais e democráticos aferidos em relação aos créditos adicionais extraordinários, sem recorrer a expedientes extraconstitucionais. 


\section{REFERÊNCIAS BIBLIOGRÁFICAS}

ABRAHAM, Marcus. Coluna Fiscal: do tributo ao crédito publico - uma nova realidade fiscal. In: Jota, Publ. 2 de junho de 2016. Disponível em: <http://jota.uol.com.br/colunafiscal-tributo-ao-credito-publico-uma-nova-realidade-fiscal>. Acesso em: 04.06.2016.

. Curso de Direito Financeiro Brasileiro. 3 ed. Rio de Janeiro: Forense, 2015.

. Orçamento Público como Instrumento de Cidadania Fiscal. In: Revista de Direitos Fundamentais e Democracia, Curitiba, v. 17, n. 17, jan./jun. 2015, pp. 188-209.

ABRANCHES, Sérgio Henrique Hudson de. Presidencialismo de coalizão: o dilema institucional brasileiro. In: Dados, rio de Janeiro, v. 31, n. 1, 1988, pp. 5-34.

ACKERMAN, Bruce. Adeus, Montesquieu. In: Revista de Direito Administrativo, Rio de Janeiro, v. 265, jan./abr. 2014, pp. 13-23.

2004, pp. 1029-2004.

. The Emergency Constitution. In: Yale Law Journal, New Haven-EUA, v. 113,

The New Separation of Powers. In: Harvard Law Review, Cambridge-EUA, v. 113, n. 3, jan. 2000, pp. 633-729.

ADEODATO, João Maurício. Ética e Retórica: para uma teoria da dogmática jurídica. São Paulo: Saraiva, 2002.

Jurisidição Constitucional à Brasileira: Situação e Limites. In: SCAFF, Fernando Facury Scaff (org.). Constitucionalizando Direitos: 15 anos da Constituição Brasileira de 1988. Rio de Janeiro: Renovar, 2003.

AFONSO, José Roberto. Memória da Assembléia Constituinte de 1987/88: as finanças públicas. In: Revista do BNDES, Rio de Janeiro, v. 6, n. 11, 1999, pp. 21-48.

ALEXY, Robert. Teoria da Argumentação Jurídica. Trad. Zilda Hutchinson Schild Silva. São Paulo: Landy, 2001.

Malheiros, 2008.

Teoria dos Direitos Fundamentais. Trad. Virgílio Afonso da Silva. São Paulo:

ARISTÓTELES. Política. Trad. Mário da Gama Kury. Brasília: Universidade de Brasília, 1985.

. Obra Jurídica. Trad. Carlos Rodrigues. São Paulo: Ícone, 1997.

. Retórica. Trad. Edson Bini. São Paulo: EDIPRO, 2011. 
Retórica. 2 ed. Trad. Manuel Alexandre Júnior, Paulo Farmhouse Alberto e Abel do Nascimento Pena. Lisboa: Imprensa Nacional-Casa da Moeda, 2005.

ARGUELHES, Diego Werneck; RIBEIRO, Leandro Molhano. O Supremo Individual: mecanismos de atuação direta dos Ministros sobre o processo político. In: Direito, Estado e Sociedade, Rio de janeiro, n. 46, jan./jun. 2015, pp. 121-155.

ASSONI FILHO, Sérgio. Controle de Constitucionalidade da Lei Orçamentária. In: CONTI, José Maurício; SCAFF, Fernando Facury. Orçamentos Públicos e Direito Financeiro. São Paulo: Revista dos Tribunais, 2011.

ATIENZA, Manuel. As Razões do Direito: Teorias da Argumentação Jurídica. 3 ed. Trad. Maria Cristina Guimarães Cupertino. São Paulo: Landy, 2003.

. Curso de Argumentación Jurídica. Madri: Trotta, 2013.

. O Direito como Argumentação. Trad. Manuel Poirier Braz. Lisboa: Escolar, 2014.

Entrevista a Neil MacCormick. In: Doxa: cuadernos de filosofia del Derecho, Alicante-ES, n. 29, 2006, pp. 479-489.

. Ni positivismo jurídico ni neoconstitucionalismo: una defensa de constitucionalismo postpositivista. In: Observatório da Jurisdição Constitucional, Brasília, a. 7, n. 2, jul./dez. 2014, pp. 1-24, p. 17.

Una Propuesta de Filosofía del Derecho para el Mundo Latino In: Doxa, Cuadernos de Filosofía del Derecho, n. 30, 2007, pp. 661-663.

BALLEIRO, Aliomar. Uma Introdução à Ciência das Finanças. 17 ed. Rio de Janeiro: Forense, 2010.

BALKIN, Jack M. A Night in the Topics: the reason of legal rhetoric and the rhetoric of legal reason. In: BROOKS, P.; GERWIRTH, P. (org.). Law's Stories: Narrative and Rhetoric in the Law. New Haven: Yale University Press, 1996, pp. 211-224.

BALLWEG, Ottmar. Retórica analítica e direito. Trad. João Maurício Adeodato. Mimeo.

. Rhetorik und Vertrauen. In: Kritik und Vertrauen: Festschift für Peter Schneider zum 70 Geburtstag. Frankfurt a.M.: Anton Hain Verlag, 1990.

BARRETTO, Érica de Santana Silva. Os Créditos Adicionais e sua Excessiva Utilização pelo Poder Executivo Federal. In: Revista Fórum de Direito Financeiro e Econômico, Belo Horizonte, ano 4, n. 6, set./fev. 2015, pp. 79-92.

BARROSO, Luís Roberto. O Direito Constitucional e a Efetividade de suas Normas: limites e possibilidades da Constituição brasileira. 9 ed. Rio de Janeiro: Renovar, 2009.

; MENDONÇA, Eduardo. O Sistema Constitucional Orçamentário. In: MARTINS, Ives Gandra da Silva; MENDES, Gilmar Ferreira; NASCIMENTO, Carlos Valder do. Tratado de Direito Financeiro. v. 1. São Paulo: Saraiva, 2013. 
- Neoconstitucionalismo e a constitucionalização do direito ( $\mathrm{O}$ triunfo tardio do direito constitucional no Brasil). In: SOUZA NETO, Cláudio Pereira de; SARMENTO, Daniel. A Constitucionalização do Direito: Fundamentos Teóricos e Aplicações Específicas. Rio de Janeiro: Lumen Juris, 2007.

BASTOS, Celso Ribeiro. Curso de Direito Financeiro e Tributário. 9 ed. São Paulo: Celso Bastos, 1999.

BECKER, Alfredo Augusto. Teoria Geral do Direito Tributário. 3 ed. São Paulo: Lejus, 1998.

BERCOVICI, Gilberto; MASSONETTO, Luís Fernando. A Constituição Dirigente Invertida: a blindagem da constituição financeira e a agonia da constituição económica. In: Boletim de Ciências Económicas, Coimbra, v. 49, 2006, pp. 57-77.

pp. 5-24.

. Constituição e Política: uma relação difícil. In: Lua Nova, São Paulo, n. 61, 2004,

Constituição Econômica e Dignidade da Pessoa Humana. In: Revista da Faculdade de Direito da Universidade de São Paulo, v. 102, jan./dez. 2007, pp. 457-467.

. Desigualdades Regionais, Estado e Constituição. São Paulo: Max Limonad, 2003.

BIJOS, Paulo Roberto Simão. Governança Orçamentária: uma relevante agenda em ascensão. In: SENADO FEDERAL. Orçamento em discussão, Brasília, n. 12, 2014.

BONAVIDES, Paulo. Curso de Direito Constitucional. 20 ed. São Paulo: Malheiros, 2007.

BRANDÃO, Rodrigo. Supremacia Judicial versus Diálogos Constitucionais: a quem cabe a última palavra sobre o sentido da Constituição? Rio de Janeiro: Lumen Juris, 2012.

BRASIL. INSTITUTO DE PESQUISA ECONÔMICA APLICADA. Políticas Sociais: acompanhamento e análise. n. 22. Brasília: IPEA, 2014.

. MINISTÉRIO DA FAZENDA. Análise da Arrecadação das Receitas Federais: dezembro/2015. Brasília: Centro de Estudos Tributários e Aduaneiros, 2016. Disponível em: $<$ http://idg.receita.fazenda.gov.br/dados/receitadata/arrecadacao/relatorios-do-resultado-daarrecadacao/arrecadacao-2015/dezembro2015/analise-mensal-dez-2015.pdf>. Acesso em: 04.07.2016.

Secretaria do Tesouro Nacional, 2016.

Dívida Pública Federal: relatório anual 2015. n. 13. Brasília: PRESIDÊNCIA DA REPÚBLICA. Lei 9.438, de 26 de fevereiro de 1997. Estima a Receita e fixa a Despesa da União para o exercício financeiro de 1997. Diário Oficial da União, Seção 1, Publ. Em 27.02.2007, p. 11.769.

Lei 9.868, de 10 de novembro de 1999. Dispõe sobre o processo e julgamento da ação direta de inconstitucionalidade e da ação declaratória de 
constitucionalidade perante o Supremo Tribunal Federal. Diário Oficial da União, Seção 1, Publ. 11.11.1999, p. 1.

. Lei 10.260, de 12 de junho de 2001. Dispõe sobre o Fundo de Financiamento ao Estudante do Ensino Superior e dá outras providencias. Diário Oficial da União, Brasília, Seção 1, Publ. em 13.07.2001, p. 2.

Lei 10.640, de 14 de janeiro de 2003. Estima a receita e fixa a despesa da União para o exercício de 2003. Diário Oficial da União, Seção 1, Publ. Em 15.01.2003, p. 1 .

Lei 11.734, de 1 de julho de 2008. Abre ao Orçamento Fiscal da União, em favor do Ministério do Planejamento, Orçamento e Gestão, crédito suplementar no valor de R \$ 7.560.000.000,00, para reforço de dotação constant da Lei Orçamentária vigente, e dá outras providências. Diário Oficial da União, Brasília, Seção 1, Publ. em 02.07.2008, p. 1.

Lei 12.202, de 14 de janeiro de 2010. Altera a Lei 10.260, de 12 de julho de 2001, que dispõe sobre o Fundo de Financiamento ao Estudante do Ensino Superior FIES. Diário Oficial da União, Brasília, Seção 1, Publ. em 15.01.2010, p. 3.

Lei 12.531, de 26 de outubro de 2011. Institui o Programa Nacional de Acesso ao Ensino Técnico e Emprego (Pronatec); altera as Leis 7.998, de 11 de janeiro de 1990, que regula o Programa do Seguro-Desemprego, o Abono Salrial e institui o Fundo de Amparo ao Trabalhador (FAT), 8.212. de 24 de julho de 1991, que dispõe sobre a organização da Seguridade Social e institui o Plano de Custeio, 10.260, de 12 de juhlo de 2011, que dispõe sobre o Fundo de Financiamento do Ensino Superior, e 11.129, de 30 de junho de 2005, que institui o Programa Nacional de Inclusão de Jovens (ProJovem); e dá outras providencias. Diário Oifical da União, Brasília, Seção 1, Publ. em 27.10.2011, p. 1.

Lei 12.608, de 10 de abril de 2012. Institui a Política Nacional de Proteção e Defesa Civil - PNPDEC; dispõe sobre o Sistema Nacional de Proteção de Defesa Civil - SINPDEC e o Conselho Nacional de Proteção e Defesa Civil - CONPDEC; autoriza a criação de sistema de informações e monitoramento de desastres; altera as leis 12.340 , de 1 de dezembro de 2010, 10.257, de 10 de juhlo de 2011, 6.766, de 19 de dezembro de 1979, 8.239, de 4 de outubro de 1991, e 9.394, de 20 de dezembro de 1996; e dá outras providências. Diário Oficial da União, Brasília, Seção 1, Publ. em 11.04.2012, p. 1.

Lei 13.242, de 30 de dezembro de 2015. Dispõe sobre as diretrizes para a elaboração e execução da lei orçamentária de 2016 e dá outras providências. Diário Oficial da União, Brasília, Seção 1, edição extra, Publ. em 31.12.2015, p. 3.

Medida Provisória 711, de 18 de janeiro de 2016. Abre crédito extraordinário, em favor de diversos órgãos dos Poderes Legislativo e Judiciário, da Defensoria Pública da União e do Ministério Público da União, no valor de R\$ 419.460.681,00, para os fins que especifica. Diário Oficial da União, Brasília, Seção 1, Publ. em 19.01.2016, p. 1.

Medida Provisória 722, de 28 de abril de 2016. Abre crédito extraordinário, em favor da Presidência da República e do Ministério do Esporte, no valor de $\mathrm{R}$ \$ 180.000.000,00, para os fins que especifica. Diário Oficial da União, Brasília, Seção 1, 
edição extra, Publ. em 28.04.2016, p. 1.

. SENADO FEDERAL. Diário do Senado Federal, Brasília, a. LXVI, n. 37, sessão de 18.03.2011, Publ. em 18.03.2011.

SUPREMO TRIBUNAL FEDERAL. Ação Direta de Inconstitucionalidade 4, Rel. Min. Sydney Sanches, Pleno, j. 11.02.1998, DJ Publ. em 21.05.1999.

. Ação Direta de Inconstitucionalidade 1.647, Plenário, Rel. Min. Carlos $\overline{\text { Velloso, j. }} \overline{02.12 .1998}$, Publ. DJ 26.03.1999, pp. 93-125.

- Ação Direta de Inconstitucionalidade 2.100, Relatoria do Ministro Néri da Silveira, Relator para acórdão Ministro Nelson Jobim, Tribunal Pleno, j. 17.12.1999, Publ em DJ $1^{\circ} .06 .2001$, pp. 238-248.

. Ação Direta de Inconstitucionalidade 2.925, Plenário, Rel. Min. Ellen Gracie, Rel. p/ Ac. Marco Aurélio, j. 19.12.2003, Publ. DJ 04.03.2005, pp. 112-188.

Ação Direta de Inconstitucionalidade 3.146, Rel. Min. Joaquim Barbosa, Pleno, j. 11.05.2006, DJ Publ. em 19.12.2006, pp. 692-748.

. Ação Direta de Inconstitucionalidade 4.426, Rel. Min. Dias Toffoli, Pleno, j. 09.02.2011, DJe Publ em. 17.05.2011.

. Ação Direta de Inconstitucionalidade 5.105, Plenário, Rel. Min. Luiz Fux, j. $1^{\circ} .10 .2015$, Publ. DJe 49 em 16.03.2016, pp. 1-197.

. Ação Direta de Inconstitucionalidade 5.287, Rel. Min. Luiz Fux, Pleno, j. 18.05.2016, DJ 106 Publ. em 24.05.2016.

Agravo Regimental em Reclamação 14.156, Rel. Min. Celso de Mello, Pleno, j. 19.02.2014, DJe 90 Publ. em 13.05.2014.

- Medida Cautelar em Ação Direta de Inconstitucionalidade 162,

Plenário, Rel. Min. Moreira Alves, j. 14.12.1989, Publ. DJ 19.09.1997, pp. 1-48.

. Medida Cautelar em Ação Direta de Inconstitucionalidade 1.717, Plenário, Rel. Min. Sydney Sanches, j. 22.09.1999, Publ. DJ 25.02.2000, pp. 63-115.

- Medida Cautelar em Ação Direta de Inconstitucionalidade 2.527, Plenário, Rel. Min. Ellen Gracie, j. 16.08.2007, Publ. Dje 147 em 23.11.2007, pp. 107-178.

Medida Cautelar em Ação Direta de Inconstitucionalidade 2.535, Relatoria do Ministro Sepúlveda Pertence, Tribunal Pleno, j. 19.12.2001, Publ. em DJ 21.11.2003, pp. 368-400.

. Medida Cautelar em Ação Direta de Inconstitucionalidade 4.048, Plenário, Rel. Min. Gilmar Mendes, j. 14.05.2008, Publ. Dje 157, em 22.08.2008, pp. 55-192. . Medida Cautelar em Ação Direta de Inconstitucionalidade 4.049, 
Plenário, Rel. Min. Ayres Britto, j. 05.11.2008, Publ. Dje 84, em 08.05.2009, pp. 187-259.

- Medida Cautelar em Ação Direta de Inconstitucionalidade 5.513, decisão monocrática, Rel. Min. Gilmar Mendes, j. 30.04.2016, Publ. Dje 89, em 04.05.2016, p. 1.

Questão de Ordem em Ação Direta de Inconstitucionalidade 1.640, Plenário, Rel. Min.Sydney Sanches, j. 12.02.1998, Publ. DJ em 03.04.1998, pp. 68-81.

Questão de Ordem em Ação Direta de Inconstitucionalidade 1.753, Plenário, Rel. Min. Sepúlveda Pertence, j. 17.09.1998, Publ. DJ 23.10.1998, pp. 36-44.

Publ. em 17.10.2003. Reclamação 935, , Rel. Min. Gilmar Pleno Mendes, j. 28.04.2003, DJ Reclamação 3.014, Rel. Min. Ayres Britto, Pleno, j. 10.03.2010, DJe 91 Publ. em 21.05.2010.

Reclamação 8.168, Rel. Min. Ellen Gracie, Rel. p/ Ac. Min Edson Fachin, Pleno, j. 19.11.2015, DJe 37 Publ. em 29.02.2016.

03.07.1952. Recurso Extraordinário 17.184, Rel. Ministro Ribeiro da Costa, j. <http://bibliotecadigital.fgv.br/ojs/index.php/rda/article/viewFile/14343/13233>. Acesso em 15.07.2016.

10.10.1957, RT 282/859.

Recurso Extraordinário 34.581, Rel. Ministro Cândido Motta, j. Recurso Extraordinário 116.119, Rel. Min. Ilmar Galvão, Rel. p/ Ac. Celso de Mello, Primeira Turma, j. 10.11.1992, Publ. DJ 24.03.1995, pp. 334-347.

Recurso Extraordinário 150.764, Plenário, Rel. Min. Sepúlveda Pertence, Red. p/ ac. Marco Aurélio, j. 16.12.1992, Publ. DJ em 02.04.1993, pp. 1497-1588.

Zavascki, DJe 19.12.2014.

Recurso Extraordinário com Agravo 849.328, Pleno, Rel. Min. Teori

Referendo em Medida Cautelar em Ação Direta de Inconstitucionalidade 4.663, Relatoria Ministro Luiz Fux, Tribunal Pleno, j. 15.10.2014, DJe 246, Publ. em 16.12.2014.

Referendo em Medida Cautelar em Arguição de Descrumpirmento de Preceito Fundamental 341, Pleno, Rel. Min. Roberto Barroso, DJe 10.08.2015.

Vigésimo Sexto Agravo Regimental em Ação Penal 470, Plenário, Rel. Joaquim Barbosa, Rel. p/ Ac. Roberto Barroso, j. 18.09.2013, DJe Publ. em 17.02.2014.

BUCCI, Maria Paula Dallari. Fundamentos para uma Teoria Jurídica das Políticas Públicas. São Paulo: Saraiva, 2013. 
BUGARIN, Paulo Soares. O Princípio Constitucional da Economicidade na Jurisprudência do Tribunal de Contas da União. 2 ed. Belo Horizonte: Fórum, 2011.

BUJANDA, Fernando Sainz de. Hacienda y Derecho: introducción al derecho financiero de nuestro tempo. v. 1. Madri: Instituto de Estudios Politicos, 1963.

CAMARGO, Guilherme Bueno de. Governança Republicana como Vetor para a Interpretação das Normas de Direito Financeiro. 239 f. Tese de Doutorado - Faculdade de Direito, Universidade de São Paulo, São Paulo, 2010.

CAMPOS, Francisco. Orçamento - natureza jurídica - lei material e lei formal - exposição e crítica da doutrina de Laband - direito comparado - elevação do imposto de vendas e consignações em São Paulo. In: Revista de Direito Administrativo, Rio de Janeiro, v. 14, jan. 1948, pp. 447-467.

CANOTILHO, José Joaquim Gomes. A Lei do Orçamento na Teoria da Lei. In: Boletim da Faculdade de Direito da Universidade de Coimbra, Estudos em homenagem ao Prof. Doutor J. J. Teixeira Ribeiro II, Coimbra-PT, número especial, 1979, pp. 543-583.

CASSESSE, Antonio. International Law. 2 ed. Hampshire: Oxford University Press, 2005.

CARVALHO, André Castro. Infraestrutura sob a perspectiva pública: instrumentos para o seu desenvolvimento. $608 \mathrm{f}$. Tese de doutorado - Faculdade de Direito, Universidade de São Paulo, São Paulo, 2013.

CASTRO, Paulo Rabello de. O Mito do Governo Grátis: o mal das políticas econômicas ilusórias e as lições de 13 países para o Brasil mudar. Rio de Janeiro: Edições de Janeiro, 2014.

CASTRO, Marcus Faro de. Globalização, Democracia e Direito Constitucional: legados recebidos e possibilidades de mudança. In: CLEVE, Clermerson Merlin; FREIRE, Alexandre (cords.). Direitos Fundamentais e Jurisdição Constitucional: análise, crítica e contribuições. São Paulo: Revista dos Tribunais, 2014.

CHRISTOPOULOS, Basile Georges Campos. Controle de Constitucionalidade de Normas Orçamentárias: o uso de argumentos consequencialistas nas decisões do Supremo Tribunal Federal. 240 f. Tese de Doutorado - Faculdade de Direito, Universidade de São Paulo, São Paulo-SP, Brasil, 2014.

CHUEIRI, Vera Karam de; GODOY, Miguel Gualano de. Constitucionalismo e democracia: soberania e poder constituinte. Revista Direito GV, São Paulo, v. 6, n. 1, jan./jun. 2010, pp. 159-174.

COELHO, Luiz Fernando. Teoria Crítica do Direito. Curitiba: HDV, 1986.

CONSELHO DE DESENVOLVIMENTO ECONÔMICO E SOCIAL. Indicadores de Iniquidade do Sistema Tributário Nacional: Relatório de Observação $n^{o}$ 2. 2. ed. Brasília: Presidência da República, 2011. 
CONTI, José Maurício. O Supremo Tribunal Federal e o Controle de Constitucionalidade em Matéria Orçamentária. In: GOMES, Marcus Lívio; ABRAHAM, Marcus; TORRES, Heleno Taveira (coords.). Direito Financeiro na Jurisprudência do Supremo Tribunal Federal: homenagem ao Ministro Marco Aurélio. Curitiba: Juruá, 2016.

CORREIA NETO, Celso de Barros. O Orçamento Público e o Supremo Tribunal Federal. In: CONTI, José Maurício; SCAFF, Fernando Facury. Orçamentos Públicos e Direito Financeiro. São Paulo: Revista dos Tribunais, 2011.

CORTI, Horacio Guillermo. Derecho Constitucional Presupuestario. 2 ed. Buenos Aires: Abeledo-Perrot, 2011. . Derecho Financiero. Buenos Aires: Abeledo-Perrot, 1997.

DERZI, Misabel de Abreu Machado. Tipo ou conceito no Direito Tributário? In: Revista da Faculdade de Direito da UFMG, Belo Horizonte, n. 30/31, 1987/1988, pp. 213-260.

DINIZ, Maria Helena. Compêndio de Introdução à Ciência do Direito. 5 ed. São Paulo: Saraiva, 1993.

DORNELLES, Francisco. O Sistema Tributário da Constituição de 1988. In: DANTAS, Bruno et al. Constituição de 1988: o Brasil 20 anos depois. Brasília: Senado Federal, 2008.

DREIER, Ralf. Concepto y Función de la Teoría General del Derecho. In: Revista de la Facultad de Derecho de la Universidad Complutense, Madri-ES, Nueva Época, n. 52, 1978, pp. 111-138.

ELIAS, Norbert. O Processo Civilizador. v. 2. Trad. Ruy Jungmann. São Paulo: Jorge Zahar, 1993.

FACHIN, Luiz Edson. Direito Civil: sentidos, transformações e fim. Rio de Janeiro: Renovar, 2015.

FALCÃO, Joaquim. O Supremo. Rio de Janeiro: Edições de Janeiro, 2015.

FARBER, Daniel; SHERRY, Suzanna. Judgment Calls: principles and politics in Constitutional Law. Oxford: Oxford University Press, 2009.

FEITOSA, Raymundo Juliano. O "feitichismo" como limite às possibilidades de concretização da Constituição Federal de 1988. In: SCAFF, Fernando Facury (org.). Constitucionalizando Direitos: 15 anos da constituição brasileira de 1988. Rio de Janeiro: Renovar, 2003.

FERNANDES, Ricardo Vieira de Carvalho. Influências Extrajurídicas sobre a Decisão Judicial: determinação, previsibilidade e objetividade do direito brasileiro. $352 \mathrm{f}$. Tese de Doutorado - Faculdade de Direito, Universidade de Brasília, Brasília-DF, Brasil, 2013.

FERRAJOLI, Luigi. A Soberania no Mundo Moderno. Trad. Carlo Coccioli e Márcio Lauria Filho. São Paulo: Martins Fontes, 2006. 
FERRAZ JUNIOR, Tércio Sampaio. Função Social da Dogmática Jurídica. 2 ed. São Paulo: Atlas, 2015.

Introdução. In: VIEHWEG, Theodor. Tópica e Jurisprudência. Trad. Tércio Sampaio Ferraz Júnior. Brasília: Departamento de Imprensa Nacional, 1979.

Teoria da Norma Jurídica. 2 ed. Rio de Janeiro: Forense, 1986.

FERREIRA FILHO, Manoel Gonçalves. A Disciplina Constitucional das Crises Econômicofinanceiras. In: Revista de Informação Legislativa, Brasília, v. 27, n. 108, out./dez. 1990, pp. $33-48$.

. Constituição e Governabilidade: ensaio sobre a (in)governabilidade brasileira. São Paulo: Saraiva, 1995.

FIGUEIREDO, Argelina Cheibub; LIMONGI, Fernando. Executivo e Legislativo na Nova Ordem Constitucional. Rio de Janeiro: FGV, 1999.

Incentivos Eleitorais, Partidos e Política Orçamentária. In: Dados, Rio de Janeiro, v. 46, n. 2, 2002, pp. 303-344.

FISS, Owen. Between Supremacy and Exclusivity. In: BAUMAN, Richard W.; KAHANA, Tsvi (org.). The Least Examined Branch: the role of legislature in the Constitutional State. Nova York: Cambridge University Press, 2006.

FRANCO, Afonso Arino de Melo. Direito Constitucional: teoria da constituição; as constituições do Brasil. 2 ed. Rio de Janeiro: Forense, 1981.

FRANCO, António Luciano de Sousa. Manual de Finanças Públicas e Direito Financeiro. v. 1. Lisboa: Faculdade de Direito de Lisboa, 1974.

FURTADO, Lucas Rocha. A Função de Controle como Fundamento do Estado Democrático de Direito. In: Revista Escola Nacional da Magistratura, Brasília, a. 7, n. 6, nov. 2012, pp. 424-441.

FUX, Luiz. Orçamento Público na Jurisprudência do STF: a possibilidade de controle judicial, a autonomia constitucional orçamentária e a problemática do orçamento participativo. In: GOMES, Marcus Lívio; ABRAHAM, Marcus; TORRES, Heleno Taveira (coords.). Direito Financeiro na Jurisprudência do Supremo Tribunal Federal: homenagem ao Ministro Marco Aurélio. Curitiba: Juruá, 2016.

GARGARELlA, Roberto. La Sala de Máquinas de la Constitución: dos siglos de constitucionalismo en América Latina (1810-2010). Buenos Aires: Katz, 2014.

2008.

. Teoría y Crítica del Derecho Constitucional. t. I. Buenos Aires: Abeledo-Perrot,

GASSEN, Valcir. Matriz Tributária brasileira: uma perspectiva para pensar o Estado, a Constituição e a Tributação no Brasil. In: GASSEN, Valcir. Equidade e Eficiência da Matriz Tributária Brasileira: Diálogos sobre Estado, Constituição e Direito Tributário. Brasília: 
Consulex, 2012.

GILL, Rosalind. Discourse Analysis. In: BAUER, Martin W.; GASKELL, George. Qualitative Researching with Text, Image and Sound: a practical handbook. Londres: Sage, 2000.

GODOY, Miguel Gualano de. Devolver a Constituição ao Povo: crítica à supremacia judicial e diálogos interinstitucionais. 267 f. Tese de doutorado - Faculdade de Direito, Universidade Federal do Paraná, Paraná, Brasil, 2015.

GRAMSCI, Antonio. Essential Classics in Politics: Antonio Gramsci. Londres: ElecBook, 1999.

GUASTINI, Riccardo. La constitucionalización del ordenamiento jurídico: El caso italiano. Trad. José Maria Lujambio. In: CARBONELL, Miguel (Org.). Neoconstitucionalismo(s). 3. ed. Madrid: Editorial Trotta, 2009.

GUERRA FILHO, Willis Santiago. Processo Constitucional e Direitos Fundamentais. 2 ed. São Paulo: Celso Bastos Editor/Instituto Brasileiro de Direito Constitucional, 2001.

GUSTIN, Miracy Barbosa de Sousa; DIAS, Maria Tereza Fonseca. (Re)pensando a Pesquisa Jurídica: teoria e prática. Belo Horizonte: Del Rey, 2002.

HÄBERLE, Peter. Hermenêutica Constitucional: a sociedade aberta dos intérpretes da Constituição - contribuição para a interpretação pluralista e procedimental da constituição. Trad. Gilmar Ferreira Mendes. Porto Alegre: Sergio Antonio Fabris, 1997.

HARADA, Kiyoshi. Direito Financeiro e Tributário. 25 ed. São Paulo: Atlas, 2016.

HIRSCHL, Ran. The New Constitutionalism and the Judicialization of Pure Politics Worldwide. In: Fordham Law Review, Nova York, v. 75, 2006-2007, pp. 721-753.

HOLMES, Stephen; SUNSTEIN, Cass. El costo de los derechos: por qué la libertad depende de los impuestos. Trad. Stella Mastrangelo. Buenos Aires: Siglo Veintiuno, 2012.

HESPANHA, António Manuel. A revolução neoliberal e a Subversão do "modelo jurídico": crise, direito e argumentação jurídica. In: GOUVEIS, Jorge Bacelar; PIÇARRA, Nuno (orgs.). A Crise e o Direito. Lisboa: Almedina, 2013.

HORVARTH, Estevão. Direito Financeiro Versus Direito Tributário: uma dicotomia desnecessária e contraproducente. In: HORVARTH, Estevão; CONTI, José Maurício; e SCAFF, Fernando Facury. Direito Financeiro, Econômico e Tributário: homenagem a Regis Fernandes de Oliveira. São Paulo: Quartier Latin, 2014.

JACKSON, Vicki C.; TUSHNET, Mark. Comparative Constitutional Law. 3 ed. Nova York: Foundation Press, 2014.

JUCÁ, Francisco Pedro; ISHIKAWA, Lauro. Orçamento Participativo e Democracia Representativa. In: GOMES, Marcus Lívio; ABRAHAM, Marcus; TORRES, Heleno Taveira (coords.). Direito Financeiro na Jurisprudência do Supremo Tribunal Federal: homenagem 
ao Ministro Marco Aurélio. Curitiba: Juruá, 2016.

JUSTEN FILHO, Marçal. Sistema Constitucional Tributário: uma aproximação ideológica. In: Revista da Faculdade de Direito da UFPR, Curitiba, a. 30, n. 30, 1998, pp. 215-233.

KANAYAMA, Rodrigo Luís. Direito, Política e Consenso: a escolha eficiente de políticas públicas. 226 f. Tese de Doutorado - Faculdade de Direito, Universidade Federal do Paraná, Curitiba, 2012.

LABAND, Paul. Derecho Presupuestario. Trad. José Zamit. Madri: Instituto de Estudios Fiscales, 1979.

LAPATZA, José Juan Ferreiro. Curso de Derecho Financiero Español: instituciones. 25 ed. Madri-ES: Marcial Pons, 2006.

LANDAU, David. Abusive Constitutionalism. In: University of California Davis Law Review, Davis-EUA, v. 47, 2013-2014, pp. 189-260.

LEITE, Harrison Ferreira. Autoridade da Lei Orçamentária. Porto Alegre: Livraria do Advogado, 2011.

LEVINSON, Sanford; BALKIN, Jack M. Constitutional Dictatorship: Its Dangers and Its Design. In: Minnesota Law Review, Minneapolis-EUA, v. 94, 2009-2010, pp. 1789-1866.

LEVITSKY, Steven; WAY, Lucan A. The Rise of Competitive Authoritarianism. In: Journal of Democracy, Washington-DC, v. 13, n. 2, abr. 2002, pp. 51-65.

LIMONGI, Fernando. A Democracia no Brasil: presidencialismo, coalizão e processo decisório. In: Novos Estudos, n. 76, nov. 2006, pp. 17-41.

; FIGUEIREDO, Argelina. Processo Orçamentário e Comportamento Legislativo: emendas individuais, apoio ao executivo e programas de governo. In: Dados, Rio de Janeiro, v. 48, n. 4, pp. 737-776.

LOEWENSTEIN, Karl. Teoría de la Constitución. Trad. Alfredo Gallego Anabitarte. 2 ed. Barcelona: Ariel, 1976.

LOPREATO, Francisco Luiz Cazeiro. O Colapso das Finanças Estaduais e a Crise da Federação. São Paulo: UNESP, 2002.

MACCORMICK, Neil. Argumentação Jurídica e Teoria do Direito. Trad. Waldea Barcellos. São Paulo: Martins Fontes, 2006.

Institutional Normative Order: a conception of Law. In: Cornell Law Review, Ithaca-NY, v. 82, p. 1051-1070.

2007. Institutions of Law: an essay in legal theory. Nova York: Oxford University Press, Questioning Sovereignty: law, state, and nation in the European Commonwealth. 
Nova York: Oxford University Press, 1999.

Elsevier, 2008.

Retórica e o Estado de Direito. Trad. Conrado Hübner Mendes. Rio de Janeiro:

MASSONETTO, Luís Fernando. O Direito Financeiro no Capitalismo Contemporâneo: a emergência de um novo padrão normativo. $145 \mathrm{f}$. Tese de Doutorado - Faculdade de Direito, Universidade de São Paulo, São Paulo, 2006.

MAQUIAVEL, Nicolau. Discurso sobre a Maneira de Prover-se de Dinheiro. In: MAQUIAVEL, Nicolau. O Príncipe - Escritos Políticos. Trad. Olívia Balduh. São Paulo: Nova Cultural, 2000.

MARINONI, Luiz Guilherme. Controle de Constitucionalidade. In: SARLET, Ingo Wolfgang; MARINONI, Luiz Guilherme; MITIDIERO, Daniel. Curso de Direito Constitucional. 4 ed. São Paulo: Saraiva, 2015.

Julgamento nas Cortes Supremas: precedente e decisão do recurso diante do novo CPC. São Paulo: Revista dos Tribunais, 2015.

MARTINS, Argemiro Cardoso Moreira; ROESLER, Claudia Rosane; JESUS, Ricardo Antonio Rezende de. A Noção de Coerência na Teoria da Argumentação Jurídica de Neil MacCormick: caracterização, limitações, possibilidades. In: Revista Novos Estudos Jurídicos, Itajaí-SC, v. 16, n. 2, mai./ago. 2011, pp. 207-221.

MAUSS, Marcel. Ensaio sobre a Dádiva. Lisboa: 70, 1988.

MENDONÇA, Eduardo Bastos Furtado de. A Constitucionalização das Finanças Públicas no Brasil: devido processo orçamentário e democracia. Rio de Janeiro: Renovar, 2010.

MENDES, Conrado Hübner. Colegisladores. In: $O$ Estado de São Paulo, p. A2, Publ. 02.05.2012.

. O Projeto de uma Corte Deliberativa. In: VOJVODIC, Adriana et al (org.). Jurisdição Constitucional no Brasil. São Paulo: Malheiros, 2012.

MENDES, Gilmar Ferreira. A Doutrina Constitucional e o Controle de Constitucionalidade como Garantia da Cidadania. In: CLÉVE, Clemerson Merlin; BARROSO, Luís Roberto (orgs.). Doutrinas Essenciais Direito Constitucional: defesa da constituição. São Paulo: Revista dos Tribunais, 2011.

; BRANCO, Paulo Gustavo Gonet. Curso de Direito Constitucional. 10 ed. São Paulo: Saraiva, 2015.

Jurisdição Constitucional: o controle abstrato de normas no Brasil e na Alemanha. São Paulo: Saraiva, 1996.

; VALE, André Rufino do. Questões Atuais sobre as Medidas Cautelares no Controle Abstrato de Constitucionalidade. In: Observatório da Jurisdição Constitucional, Brasília, a. 5, 2011/2012, pp. 1-23. 
MENDONÇA, Eduardo Bastos Furtado de. A Constitucionalização das Finanças Públicas no Brasil: devido processo orçamentário e democracia. Rio de Janeiro: Renovar, 2010.

MIRANDA, Jorge. Teoria do Estado e da Constituição. Rio de Janeiro: Forense, 2002.

MONCADA, Luis S. Cabral de. A ploblemática juridica do planeamento económico. Coimbra: Coimbra, 1985.

MONTESQUIEU. Do Espírito das Leis. Trad. Fernando Henrique Cardoso e Leôncio Martins Rodrigues. 2 ed. São Paulo: Abril Cultural, 1979.

MORAIS, Carlos Blanco de. Curso de Direito Constitucional: teoria da constituição em tempo de crise do estado social. v. 2. t. 2. Coimbra: Coimbra, 2014.

MURPHY, Liam; NAGEL, Thomas. O mito da propriedade: os impostos e a justiça. Trad. Marcelo Brandão Cipolla. São Paulo: Martins Fontes, 2005.

MUSGRAVE, Richard A. Schumpeter's crisis of the Tax State: an essay in fiscal sociology. In: Journal of Evolutionary Economics, v. 2, n. 2, pp. 89-113.

1968.

. Teoría de la Hacienda Publica. Trad. Jose Maria Lozano Irueste. Madri: Aguilar,

NABAIS, José Casalta. O Dever Fundamental de Pagar Impostos. Coimbra: Almedina, 1998.

NEME, Eliana Franco; ARAUJO, Luiz Alberto David. O Controle de Constitucionalidade Concetrado de Normas Orçamentárias. In: CONTI, José Maurício; SCAFF, Fernando Facury. Orçamentos Públicos e Direito Financeiro. São Paulo: Revista dos Tribunais, 2011.

NEVES, Marcelo. Constitucionalização Simbólica. In: CANOTILHO, J. J. Gomes et al. Comentários à Constituição do Brasil. São Paulo: Saraiva/Almedina, 2013.

NINO, Carlos Santiago. Fundamentos de Derecho Constitucional: análisis filosófico, jurídico y politológico de la práctica constitucional. Buenos Aires: Astrea de Alfredo y Ricardo Depalma, 1992.

La Constitución de la Democracia Deliberativa. Trad. Roberto P. Saba. Barcelona: Gedisa, 1997.

NOBRE, Marcos. Indeterminação e Estabilidade. In: Novos Estudos, São Paulo, n. 82, nov. 2008, pp. 97-106.

NUNES, António José Avelãs. Quo Vadis, Europa? São Paulo: Contracorrente, 2016.

NUSSBAUM, Martha C. Hiding from Humanity: disgust, shame, and the law. Princeton: Princeton University Press, 2004.

O’DONNEL, Guillermo. Democracia Delegativa? In: Novos Estudos, São Paulo, n. 31, out. 1991, pp. 25-40. 
OLIVEIRA, Regis Fernandes de. Direito Financeiro: conceito, autonomia e fontes. In: MARTINS, Ives Gandra da Silva; MENDES, Gilmar Ferreira; NASCIMENTO, Carlos Valder do. Tratado de Direito Financeiro. v. 1. São Paulo: Saraiva, 2013.

Curso de Direito Financeiro. 3 ed. São Paulo: Revista dos Tribunais, 2010.

OLIVEIRA, Ricardo Rachid de. A Relevância Penal da Inadimplência Tributária. Curitiba: Juruá, 2013.

PASSEROTTI, Denis Camargo. O Uso das Medidas Provisórias para Instituição de Créditos Adicionais Extraordinários e o Orçamento Público. In: Revista Fórum de Direito Financeiro e Econômico, Belo Horizonte, ano 3, n. 5, mar./ago. de 2014, pp. 17-132.

PEREIRA, Carlos; MUELLER, Bernardo. Comportamento Estratégico em Presidencialismo de Coalizão: as relações entre Executivo e Legislativo na elaboração do orçamento brasileiro. In: Dados, Rio de Janeiro, v. 45, n. 2, 2002, pp. 265-301.

PERELMAN, Chaim; OLBRECHTS-TYTECA, Lucie. Tratado da Argumentação: a nova retórica. Trad. Maria Ermantina de Almeida Prado Galvão. São Paulo: Martins Fontes, 2005.

PIKKETY, Thomas. Capital in the Twenty-First Century. Trad. Arthur Goldhammer. Cambridge: Belknap Press of Harvard University Press, 2014.

PINTO, Élida Graziane. Financiamento dos Direitos à Saúde e à Educação: uma perspectiva constitucional. Belo Horizonte: Fórum, 2015.

PINTO, Marcos Barbosa. Constituição e Democracia. Rio de Janeiro: Renovar, 2009.

PLATÃo. Diálogos: Mênon - Banquete - Fedro. Trad. Jorge Paleikat. 5 ed. Rio de Janeiro: Globo, 1962.

PRZEWORSKI, Adam. Democracy and the Market: political and economic reforms in Eastern Europe and Latin America. Nova York: Cambridge University Press, 1991.

PULIDO, Carlos Libardo Bernal. Direitos Fundamentais, Juristocracia Constitucional e Hiperpresidencialismo na América Latina. Trad. Graça Maria Borges de Freitas. In: Revista Jurídica da Presidência, Brasília, v. 17, n. 111, fev./maio 2016, pp. 15-34.

RAMOS, Elival da Silva. Controle de Constitucionalidade no Brasil: perspectivas de evolução. São Paulo: Saraiva, 2010.

REIS, Issac. Análise empírico-retórica do Discurso Constitucional: uma contribuição metodológica à pesquisa de base em direito. In: RODRIGUES, Horário Wanderlei et alii (coord.). Direito, Educação, Ensino e Metodologia Jurídicos. Florianópolis: CONPEDI, 2014.

Limites à legitimidade da jurisdição constitucional: análise retórica das cortes constitucionais do Brasil e da Alemanha. 265 f. Tese de Doutorado - Faculdade de Direito, Universidade Federal de Pernambuco, Recife-PE, Brasil, 2013. 
REUBEN, William. The Role of Civic Engagement and Social Accountability in the Governance Equation. In: Social Development Notes, Washington-DC, n. 75, mar. 2003, pp. $1-4$.

ROCHA, Antonio Sérgio Carvalho. As Partes e o Todo: congresso nacional, executivo e o problema do orçamento no Brasil. In: Perspectivas, São Paulo, v. 34, jul.dez. 2008, pp. 55-78.

Genealogia da Constituinte: do autoritarismo à democratização. In: Lua Nova, São Paulo, n. 88, 2013, pp. 29-87.

ROCHA, Francisco Sérgio Silva. Controle do Orçamento Público e o Juízo de Constitucionalidade: problemas na execução e na inexecução orçamentária. $343 \mathrm{f}$. Tese de Doutorado - Instituto de Ciências Jurídicas, Universidade Federal do Pará, Belém-PA, Brasil, 2010.

RODRIGUEZ, José Rodrigo; PÜSCHEL, Flavia Portella; MACHADO, Marta Rodriguez de Assis. O Raciocínio Jurídico-dogmático e suas Relações com o Funcionamento do Poder Judiciário e a Democracia. In: Anais do $3^{\circ}$ Congresso Latino Americano do Ciência Política, Associação Latino-Americana de Ciência Política, Campinas, Brasil, 2006.

RODRÍGUEZ, Víctor Gabriel. Argumentação Jurídica: técnicas de persuasão e lógica informal. São Paulo: Martins Fontes, 2005.

ROSSITER, Clinton L. Constitutional Dictatorship: crisis governement in the modern democracies. Princeton: Princeton University Press, 1948.

ROESLER, Claudia Rosane. O papel de Theodor Viehweg na fundação das teorias da argumentação jurídica. In: Revista Eletrônica Direito e Política, Programa de Pós-Graduação Stricto Sensu em Ciência Jurídica da UNIVALI, Itajaí, v. 4, n. 3, 3o. quadrimestre de 2009, pp. 36-54, p. 48.

Theodor Viehweg: ¿um constitucionalista adelantado a su tiempo? Trad. Ángel Espinosa Gadea. In: Doxa: cuardernos de filosofia del derecho, Alicante, Espanha, n. 29, 2006, pp. 295-318.

Theodor Viehweg e a Ciência do Direito: tópica, discurso, racionalidade. 2 ed. Belo Horizonte: Arraes, 2013.

ROSSITER, Clinton L. Constitutional Dictatorship: crisis governement in the modern democracies. Princeton: Princeton University Press, 1948.

SADEK, Maria Tereza Aina. Poder Judiciário: uma nova construção institucional. In: Revista da Escola Nacional da Magistratura, Brasília, a. VII, n. 6, nov. 2012, pp. 392-411.

SAMPAIO, Marco Aurélio. A Medida Provisória no presidencialismo de coalizão. São Paulo: Malheiros, 2007.

SANTOS, António Carlos dos. Cidadania Europeia, Contribuinte europeu. Uma Relação com o Futuro? In: HORVARTH, Estevão; CONTI, José Maurício; SCAFF, Fernando Facury 
(orgs.). Direito Financeiro, Econômico e Tributário: estudos em homenagem a Regis Fernandes de Oliveira. São Paulo: Quartier Latin, 2014.

SANTOS, Marcelo Fernandes Pires dos. Retórica, Teoria da Argumentação e Pathos: o problema das emoções no discurso jurídico. 151 f. Dissertação de Mestrado, Faculdade de Direito, Universidade de Brasília, Brasília, Brasil, 2015.

SARMENTO, Daniel. Ubiqüidade Constitucional: Os Dois Lados da Moeda. In: SARMENTO, Daniel; SOUZA NETO, Cláudio Pereira de (Coords.). A Constitucionalização do Direito: Fundamentos Teóricos e Aplicações Específicas. Rio de Janeiro: Lumen Juris, 2007.

SARLET, Ingo Wolfgang. A Eficácia dos direitos fundamentaios: uma teoria geral dos direitos fundamentais na perspectiva constitucional. 10 ed. Porto Algre: Livraria do Advogado, 2010.

SCAFF, Fernando Facury. As Agruras do Homem no Estado Endividado. In: NUNES, António José Avelãs. Quo Vadis, Europa? São Paulo: Contracorrente, 2016.

Como a Sociedade Financia o Estado para a Implementação dos Direitos Humanos no Brasil. In: SCAFF, Fernando Facury (org.). Constitucionalismo, Tributação e Direitos Humanos. Rio de Janeiro: Renovar, 2007.

. Crédito Público e Sustentabilidade Financeira. In: Revista Fórum de Direito Financeiro e Econômico, Belo Horizonte, a. 3, n. 5, mar./ago. 2014, pp. 55-70.

; ROCHA, Francisco Sergio Silva. Equilíbrio Orçamentário e Sustentatibildiade Financeira: anotações sobre o Brasil. In: Revista dos Tribunais, São Paulo, v. 925, nov. 2012, pp. 175-201.

Royalties do Petróleo, Minério e Energia: aspectos constitucionais, financeiros e tributários. São Paulo: RT, 2014.

SCHAUER, Frederick. Precedent. In: Stanford Law Review, Palo Alto-EUA, v. 39, n. 571, fev. 1987, pp. 571-605.

Transparency in Three Dimensions. University of Illinois Law Review, IlinoisEUA, n. 4, 2011, pp. 1339-1358, pp.1343-1344.

SCHIER, Paulo Ricardo. Filtragem Constitucional: construindo uma nova dogmática jurídica. Porto Alegre, Sérgio Antônio Fabris, 1999.

SCHUMPETER, Joseph A. The Economics and Sociology of Capitalism: the crisis of the tax state. In: BACKHAUS, Jürgen G. (ed.). Navies and State Formation: the schumpeter hypothesis revisited and reflected. Munique: LIT Verlag, 2012.

SCHOUERI, Luís Eduardo. Direito Tributário. 5 ed. São Paulo: Saraiva, 2015.

SERRA, José. A Constituição e o Gasto Público. In: Planejamento e Políticas Públicas, Brasília, n. 1, jun. 1989, pp. 93-106. 
SILVA, Christine Oliveira Peter da. Transjusfundamentalidade: diálogos transnacionais sobre direitos fundamentais. Curitiba: CRV, 2014.

SILVA, José Afonso da. Curso de Direito Constitucional Positivo. 31 ed. São Paulo: Malheiros, 2008.

Orçamento-Programa no Brasil. São Paulo: Revista dos Tribunais, 1973.

SILVA, Virgílio Afonso da. De Quem Divergem os Divergentes: os votos vencidos no Supremo Tribunal Federal. In: Direito, Estado e Sociedade, Rio de Janeiro, n. 47, jul./dez. 2015, pp. 205-225.

SOBOTA, Katharina. System and Flexibility in Law. In: Argumentation, Holanda, v. 5, n. 3, ago. 1991, pp. 275-282.

The Rhetorical Construction of Law. In: International Journal for the Semiotics of Law, v. 5, n. 1, fev. 1992, pp. 39-54.

SOUSA, Leomar Barros Amorim. A Produção Normativa do Poder Executivo: medidas provisórias, leis delegadas e regulamentos. Brasília: Brasília Jurídica, 1999.

SOUSA, Rubens Gomes de. Normas Gerais do Direito Financeiro. In: Revista de Direito Administrativo, Rio de Janeiro, v. 37, jan. 1954, pp. 12-34.

STERN, Klaus. Derecho del Estado de la Republica Federal Alemana. Trad. Javier Pérez Rojo e Pedro Cruz Villalón. Madri: Centro de Estudios Constitucionales, 1987.

SUNSTEIN, Cass. Legal Reasoning and Political Conflict. Nova York: Oxford University Press, 1996.

TAVARES, André Ramos. Curso de Direito Constitucional. 13 ed. São Paulo: Saraiva: 2015.

TIMBÓ, Ivo Cordeiro Pinho. A Natureza Jurídica do Orçamento Público. 309f. Tese de Doutorado - Universidade Presbiteriana Mackenzie, São Paulo, 2013.

TORRES, Heleno Taveira. Direito Constitucional Financeiro: teoria da constituição financeira. São Paulo: RT, 2014.

TORRES, Ricardo Lobo. A Constitucionalização do Direito Financeiro. In: SOUZA NETO, Claudio Pereira de; SARMENTO, Daniel (coords.). A Constitucionalização do Direito: fundamentos teóricos e aplicações específicas. Rio de Janeiro: Lumen Juris, 2007.

Renovar, 1991.

. A Idéia de Liberdade no Estado Patrimonial e no Estado Fiscal. Rio de Janeiro:

Art. 165. In: CANOTILHO, J. J. Gomes et al. Comentários à Constituição do Brasil. São Paulo: Saraiva/Almedina, 2013.

O Orçamento na Constituição. Rio de Janeiro: Renovar, 1995. 
TUSHNET, Mark. Authoritarian Constitutionalism. In: Cornell Law Review, Ithaca-EUA, v. 100, 2014-2015, pp. 391-461.

Taking the Constitution Away From The Courts. New Jersey: Princeton, 1999.

VALE, André Rufino do. Argumentação Constitucional: um estudo sobre a deliberação nos tribunais constitucionais. 415 f. Tese de Doutorado - Faculdade de Direito, Universidade de Brasília/Universidade de Alicante, Brasília-DF/Alicante-ES, Brasil/Espanha, 2015.

VELLOSO, Raul et al. Infraestrutura: os caminhos para sair do buraco. Rio de Janeiro: Instituto Nacional de Altos Estudos, 2012.

; MENDES, Marcos. O Dia do Juízo Fiscal. In: VELLOSO, Raul; MENDES, Marcos; FREITAS, Paulo Springer de. O Dia do Juízo Fiscal. Rio de Janeiro: Instituto Nacional de Altos Estudos, 2016.

Para Destravar o Investimento em Rodovias. In: VELLOSO, Raul; MENDES, Marcos; FREITAS, Paulo Springer de. O Dia do Juízo Fiscal. Rio de Janeiro: Instituto Nacional de Altos Estudos, 2016, p. 113.

VERÍSSIMO, Marcos Paulo. A Constituição de 1988, Vinte Anos Depois: suprema corte e ativismo judicial “à brasileira". In: Revista Direito GV, São Paulo, v. 4, n. 2, jul./dez. 2008, pp. 407-440.

VICTOR, Sérgio Antônio Ferreira. Presidencialismo de coalizão: exame do atual sistema de governo brasileiro. São Paulo: Saraiva, 2015.

VIEIRA, Oscar Vilhena. Supremocracia. In: Direito GV, São Paulo, n. 4, v. 2, jul./dez. 2008, pp. 441-464.

VIEHWEG, Theodor. Sobre la relación entre filosofia del derecho, teoria del derecho y dogmatica jurídica. In: VIEHWEG, Theodor. Tópica y filosofía del derecho. 2 ed. Trad. De Jorge M. Seña. Barcelona: Gedisa, 1997.

Tópica e Jurisprudência. Trad. Tércio Sampaio Ferraz Júnior. Brasília: Departamento de ImprensaNacional, 1979.

VODJVODIC, Adriana de Moraes. Precedente e Argumentação no Supremo Tribunal Federal: entre a vinculação ao passado e a sinalização para o futuro. $269 \mathrm{f}$. Tese de Doutorado - Faculdade de Direito, Universidade de São Paulo, São Paulo, 2012.

VORLÄNDER, Hans. What is "Constitutional Culture"? In: HENSEL, Silke et al (ed.). Constitutional Cultures: on the concept and representation of constitutions in the atlantic world. Newcastle: Cambridge Scholars, 2012.

WALDRON, Jeremy. Principles of Legislation. In: BAUMAN, Richard W.; KAHANA, Tsvi (orgs.). The Least Examined Branch: the role of legislature in the Constitutional State. Nova York: Cambridge University Press, 2006. 
Stare Decidis and The Rule of Law: a layered approach. In: Michigan Law Review, Michigan-EUA, n. 111, Out. 2012, pp. 1-31.

WAMBIER, Teresa Arruda Alvim. A Vinculatividade dos Precedentes e o Ativismo Judicial: paradoxo apenas aparente. In: DIDIER JUNIOR, Fredie; et al. (orgs.). Precedentes. Salvador: Juspodivm, 2015.

WARAT, Luís Alberto. O Senso Comum Teórico dos Juristas. In: FARIA, José Eduardo (org.). A Crise do Direito numa Sociedade em Mudança. Brasília: UnB, 1988.

YUN-CASALILLA, Bartolomé; O'BRIEN, Patrick K (eds.). The Rise of Fiscal States: a global history 1500-1914. Nova York: Cambridge University Press, 2012.

ZOLO, Danilo. Teoria e Crítica do Estado de Direito. In: COSTA, Pietro; ZOLO, Danilo (orgs.). O Estado de Direito: história, teoria, crítica. Trad. Carlo Alberto Dastoli. São Paulo: Martins Fontes, 2006. 


\section{ANEXO A - EMENTA, ACÓRDÃO E EXTRATO DE ATA DA ADI-MC 4.048}

\section{MED. CAUT. EM AÇÃO DIRETA DE INCONSTITUCIONALIDADE 4.048-1 DISTRITO FEDERAL}

Relator

Reqte.(s)

Adv.(a/s)

Reqdo.(a/s)

$\operatorname{Adv.(a/s)~}$

\author{
: $\quad$ Min. Gilmar Mendes \\ : $\quad$ Partido da Social Democracia Brasileira - PSDB \\ : Afonso Assis Ribeiro e Outro(a/s) \\ : Presidente da República \\ : $\quad$ Advogado-geral da União
}

EMENTA: Medida Cautelar em Ação Direta de Inconstitucionalidade. Medida Provisória n ${ }^{\circ}$ 405, de 18.12.2007. Abertura de crédito extraordinário. Limites constitucionais à atividade legislativa excepcional do Poder Executivo na edição de medidas provisórias.

I. MEDIDA PROVISÓRIA E SUA CONVERSÃO EM LEI. Conversão da medida provisória na Lei $\mathrm{n}^{\circ} 11.658 / 2008$, sem alteração substancial. Aditamento ao pedido inicial. Inexistência de obstáculo processual ao prosseguimento do julgamento. A lei de conversão não convalida os vícios existentes na medida provisória. Precedentes.

II. Controle abstrato de constitucionalidade de normas orçamentárias. Revisão de jurisprudência. O Supremo Tribunal Federal deve exercer sua função precípua de fiscalização da constitucionalidade das leis e dos atos normativos quando houver um tema ou uma controvérsia constitucional suscitada em abstrato, independente do caráter geral ou específico, concreto ou abstrato de seu objeto. Possibilidade de submissão das normas orçamentárias ao controle abstrato de constitucionalidade.

III. Limites constitucionais à atividade legislativa excepcional do Poder Executivo na edição de medidas provisórias para abertura de crédito extraordinário. Interpretação do art. $167, \S 3^{\circ}$ c/c o art. 62, § $1^{\circ}$, inciso I, alínea "d”, da Constituição. Além dos requisitos de relevância e urgência (art. 62), a Constituição exige que a abertura do crédito extraordinário seja feita apenas para atender a despesas imprevisíveis e urgentes. Ao contrário do que ocorre em relação aos requisitos de relevância e urgência (art. 62), que se submetem a uma ampla margem de discricionariedade por parte do Presidente da República, os requisitos de imprevisibilidade e urgência (art. 167, § $3^{\circ}$ ) recebem densificação normativa da Constituição. Os conteúdos semânticos das expressões "guerra", "comoção interna" e "calamidade pública" constituem vetores para a interpretação/aplicação do art. $167, \S 3^{\circ} \mathrm{c} / \mathrm{c} \mathrm{o}$ art. $62, \S 1^{\circ}$, inciso I, 
alínea "d", da Constituição. "Guerra", "comoção interna" e "calamidade pública" são conceitos que representam realidades ou situações fáticas de extrema gravidade e de 187onsequências imprevisíveis para a ordem pública e a paz social, e que dessa forma requerem, com a devida urgência, a adoção de medidas singulares e extraordinárias. A leitura atenta e a análise interpretativa do texto e da exposição de motivos da MP n ${ }^{\circ}$ 405/2007 demonstram que os créditos abertos são destinados a prover despesas correntes, que não estão qualificadas pela imprevisibilidade ou pela urgência. A edição da MP n 405/2007 configurou um patente desvirtuamento dos parâmetros constitucionais que permitem a edição de medidas provisórias para a abertura de créditos extraordinários.

IV. Medida cautelar deferida. Suspensão da vigência da Lei $n^{\circ} 11.658 / 2008$, desde a sua publicação, ocorrida em 22 de abril de 2008.

\title{
A C Ó R D Ã O
}

Vistos, relatados e discutidos estes autos, acordam os Ministros do Supremo Tribunal Federal, em Sessão Plenária, na conformidade da ata de julgamento e das notas taquigráficas, retificando a proclamação do dia 17 de abril do corrente para constar que o Tribunal, preliminarmente, por maioria, conheceu da ação, prosseguindo no julgamento, também por maioria, conceder a liminar, nos termos do voto do Relator.

Brasília, 14 de maio de 2008.

\author{
MINISTRO GILMAR MENDES
}

PRESIDENTE E RELATOR

\section{EXTRATO DE ATA}

Decisão: Após o voto do Senhor Ministro Gilmar Mendes (relator), deferindo a cautelar, no que foi acompanhado pelos Senhores Ministros Eros Grau, Cármen Lúcia, Carlos Britto e Marco Aurélio, e os votos dos Senhores Ministros Ricardo Levandowski, Joaquim Barbosa e Cezar Peluso, indeferindo-a, o julgamento foi suspenso. Falaram: pelo requerente, o Dr. Rodolfo Machado Moura, e, pela Advocacia-Geral da União, o Ministro José Antônio Dias 
Toffoli. Ausentes, justificadamente, a Senhora Ministra Ellen Gracie (Presidente) e os Senhores Ministros Celso de Mello e Menezes Direito. Presidência do Senhor Ministro Gilmar Mendes (Vice-Presidente). Plenário, 17.04.2008.

Decisão: Chamado o feito para prosseguimento do julgamento, antecipou o pedido de vista dos autos a Senhora Ministra Ellen Gracie. Ausente, justificadamente, o Senhor Ministro Eros Grau. Presidência do Senhor Ministro Gilmar Mendes. Plenário, 07.05.2008.

Decisão: Retificada a proclamação do dia 17 de abril do corrente para constar que o Tribunal, preliminarmente, conheceu da ação, vencido o Senhor Ministro Cezar Peluso. Em seguida, prosseguindo no julgamento, o Tribunal, por maioria, concedeu a liminar, nos termos do voto do relator, Ministro Gilmar Mendes (Presidente), vencidos os Senhores Ministros Ricardo Lewandowski, Joaquim Barbosa, Cezar Peluso, Ellen Gracie e Menezes Direito. Plenário, 14.05.2008.

Presidência do Senhor Ministro Gilmar Mendes. Presentes à sessão os Senhores Ministros Celso de Mello, Marco Aurélio, Ellen Gracie, Cezar Peluso, Carlos Britto, Joaquim Barbosa, Eros Grau, Ricardo Lewandowski, Cármen Lúcia e Menezes Direito.

Procurador-Geral da República, Dr. Antônio Fernando Barros e Silva de Souza. 


\section{ANEXO B - VISÃO GLOBAL DA ADI-MC 4.048 E INCIDÊNCIA DE INDICADORES RETÓRICOS}

Uma visão global da decisão na ADI-MC 4.048 levada a efeito no Tribunal Pleno do STF pode ser extraída do seguinte quadro, no qual se destacam as manifestações processuais em epígrafe e respectiva quantidade de laudas no DJe:

Quadro 4 - Visão global da ADI-MC 4.048

\begin{tabular}{|l|l|}
\hline \multicolumn{1}{|c|}{ EPÍGRAFE } & \multicolumn{1}{|c|}{ INTERVALO DE PÁGINAS (55-192) } \\
\hline Ementa & $55-56$ (2 laudas) \\
\hline Relatório (Min. Gilmar Mendes) & $57-60$ (4 laudas) \\
\hline Voto (Min. Gilmar Mendes) & $61-89$ (29 laudas) \\
\hline Voto na Preliminar (Min. Cármen Lúcia) & 90 (1 lauda) \\
\hline Voto na Preliminar (Min. Carlos Britto) & $91-92$ (2 laudas) \\
\hline Voto na Preliminar (Min. Cezar Peluso) & 93 (1 lauda) \\
\hline Voto na Preliminar (Min. Marco Aurélio) & $94-95$ (2 laudas) \\
\hline Voto na Preliminar (Min. Eros Grau) & 96 (1 lauda) \\
\hline Voto (Min. Cármen Lúcia) & $97-98$ (2 laudas) \\
\hline Voto (Min. Ricardo Lewandowski) & $99-101$ (3 laudas) \\
\hline Voto (Min. Joaquim Barbosa) & $102-103$ (2 laudas) \\
\hline Debate (Min. Gilmar Mendes) & $114-122$ (9 laudas) \\
\hline Voto (Min. Carlos Britto) & laudas) \\
\hline
\end{tabular}




\begin{tabular}{|l|l|}
\hline Voto (Min. Marco Aurélio) & $123-124$ (2 laudas) \\
\hline Extrato de Ata & 125 (1 lauda) \\
\hline Voto Vista (Min. Ellen Gracie) & $126-133$ (8 laudas) \\
\hline Voto (Min. Menezes Direito) & 134 (1 lauda) \\
\hline Voto (Min. Celso de Mello) & $135-175$ (41 laudas) \\
\hline Aditamento ao Voto (Min. Gilmar Mendes) & $176-179$ (4 laudas) \\
\hline Confirmação de Voto (Min. Ayres Britto) & $180-182$ (3 laudas) \\
\hline Debate (Min. Ricardo Lewandowski) & $183-190$ (8 laudas) \\
\hline Extrato de Ata & $191-192$ (2 laudas) \\
\hline
\end{tabular}

Fonte: elaboração própria.

A partir dessa aproximação inicial, pode-se conceber com maior percuciência a dimensão qualitativa da frequência, utilização e valor dos indicadores definidos no Capítulo 2 da presente pesquisa, uma vez que a quantidade de ocorrências, por si só, desconsideradas a extensão da manifestação e a diversidade de indicadores, não permitiria delinear perfis retóricos de cada Ministro votante, das correntes vencida e vencedora, assim como da Corte globalmente tomada.

Posto isso, expõe-se a seguinte tabela na qual estão referidas as ocorrências de indicadores por Ministro. Com base nela, pôde-se realizar a análise desenvolvida no item 2.5 do Capítulo 2:

Tabela 2 - Incidência de Indicadores Retóricos por Ministro

\begin{tabular}{|l|l|l|l|l|l|l|l|l|l|l|l|l|}
\hline & E1 & E2 & E3 & E4 & P1 & P2 & P3 & P4 & L1 & L2 & L3 & L4 \\
\hline GM & $\mathbf{5}$ & $\mathbf{4}$ & $\mathbf{1}$ & $\mathbf{4}$ & $\mathbf{6}$ & $\mathbf{9}$ & $\mathbf{4}$ & $\mathbf{3}$ & $\mathbf{4}$ & $\mathbf{3}$ & $\mathbf{4}$ & $\mathbf{7}$ \\
\hline CM & $\mathbf{5}$ & $\mathbf{8}$ & $\mathbf{6}$ & $\mathbf{1 0}$ & $\mathbf{8}$ & $\mathbf{5}$ & & & $\mathbf{3}$ & & $\mathbf{1}$ & \\
\hline MA & & $\mathbf{2}$ & $\mathbf{2}$ & $\mathbf{2}$ & $\mathbf{1}$ & $\mathbf{2}$ & & & & & & \\
\hline EL & & & 2 & 5 & 3 & 1 & & & & 2 & & \\
\hline
\end{tabular}




\begin{tabular}{|l|l|l|l|l|l|l|l|l|l|l|l|l|}
\hline CP & & 1 & 2 & 6 & & 7 & & 3 & & 1 & & 1 \\
\hline CB & $\mathbf{1}$ & $\mathbf{3}$ & $\mathbf{6}$ & & & $\mathbf{2}$ & $\mathbf{1}$ & $\mathbf{2}$ & $\mathbf{1}$ & & $\mathbf{1}$ & $\mathbf{1}$ \\
\hline JB & & & & 3 & & & & 2 & & & & \\
\hline EG & & & & $\mathbf{1}$ & & & & & & & & \\
\hline RL & & & 1 & 1 & & 2 & & 1 & 1 & & & \\
\hline CL & $\mathbf{2}$ & & & & $\mathbf{1}$ & $\mathbf{1}$ & & $\mathbf{1}$ & & & & \\
\hline MD & & & & 1 & & & & & & & & \\
\hline C+ & $\mathbf{1 3}$ & $\mathbf{1 7}$ & $\mathbf{1 5}$ & $\mathbf{1 7}$ & $\mathbf{1 6}$ & $\mathbf{1 9}$ & $\mathbf{5}$ & $\mathbf{6}$ & $\mathbf{8}$ & $\mathbf{3}$ & $\mathbf{6}$ & $\mathbf{8}$ \\
\hline C- & 0 & 1 & 5 & 16 & 3 & 10 & 0 & 6 & 1 & 3 & 0 & 1 \\
\hline Total & 13 & 18 & 20 & 33 & 19 & 29 & 5 & 12 & 9 & 6 & 6 & 9 \\
\hline
\end{tabular}

Fonte: elaboração própria

Índice

GM - Min. Gilmar Mendes

$\mathrm{CM}$ - Min. Celso de Mello

MA - Min. Marco Aurélio

EL - Min. Ellen Gracie

$\mathrm{CP}$ - Min. Cezar Peluso

CB - Min. Carlos Britto

JB - Min. Joaquim Barbosa

EG - Min. Eros Grau

RL - Min. Ricardo Lewandowski

CL - Min. Cármen Lúcia

MD - Ministro Menezes Direito

C+ - Corrente majoritária

C- - Corrente minoritária

Notas:

Tabela organizada de acordo com a ordem decrescente de votação.

As linhas negritadas indicam o pertencimento do Ministro à corrente majoritária no julgamento. 


\section{ANEXO C - LISTA DE MEDIDAS PROVISÓRIAS PARA ABERTURA DE CRÉDITOS EXTRAORDINÁRIOS (2008-2015)}

Quadro 5 - Lista de Medidas Provisórias que abrem créditos extraordinários no período de 2008 a 2015

\begin{tabular}{|c|c|c|c|}
\hline $\mathrm{N}^{\mathrm{o}}$ & Medida Provisória & Ementa & Situação \\
\hline 1 & $\begin{array}{l}\text { Publ. em DOU } \\
\text { 31.12.2015 }\end{array}$ & $\begin{array}{l}\text { Abre crédito extraordinário, em } \\
\text { favor dos Ministérios da } \\
\text { Agricultura, Pecuária } \\
\text { Abastecimento, da Saúde, da } \\
\text { Cultura, do Esporte, da Defesa, } \\
\text { da Integração Nacional e do } \\
\text { Turismo, da Secretaria de } \\
\text { Aviação Civil, da Secretaria de } \\
\text { Portos e de Transferências a } \\
\text { Estados, Distrito Federal e } \\
\text { Municípios, no valor de R\$ } \\
\text { 1.318.639.330,00, para os fins } \\
\text { que especifica. }\end{array}$ & $\begin{array}{l}\text { Conversão em lei com } \\
\text { veto parcial } \\
\text { Lei } 13.275 / 2016\end{array}$ \\
\hline 2 & $\begin{array}{l}\text { Publ. em DOU } \\
\text { 17.12.2015 }\end{array}$ & $\begin{array}{l}\text { Abre crédito extraordinário, em } \\
\text { favor dos Ministérios da Saúde, } \\
\text { do Trabalho e Emprego e das } \\
\text { Cidades e de Encargos } \\
\text { Financeiros da União, no valor } \\
\text { de R\$ } 37.579 .334 .525,00 \text {, para } \\
\text { os fins que especifica. }\end{array}$ & $\begin{array}{l}\text { Conversão em lei } \\
\text { Lei } 13.276 / 2016\end{array}$ \\
\hline 3 & $\begin{array}{l}\text { Publ. em DOU } \\
\text { 09.10.2015 }\end{array}$ & $\begin{array}{l}\text { Abre crédito extraordinário, em } \\
\text { favor dos Ministérios da Justiça, } \\
\text { das Relações Exteriores, dos } \\
\text { Transportes, da Defesa e da } \\
\text { Integração Nacional, no valor de } \\
\text { R\$ 950.246.149,00, para os fins } \\
\text { que especifica. }\end{array}$ & $\begin{array}{l}\text { Conversão em lei } \\
\text { Lei } 13.198 / 2015\end{array}$ \\
\hline 4 & 686 , de 30.07 .2015 & Abre crédito extraordinário, em & Conversão em lei \\
\hline
\end{tabular}




\begin{tabular}{|c|c|c|c|}
\hline & $\begin{array}{l}\text { Publ. em } \\
31.07 .2015\end{array}$ & 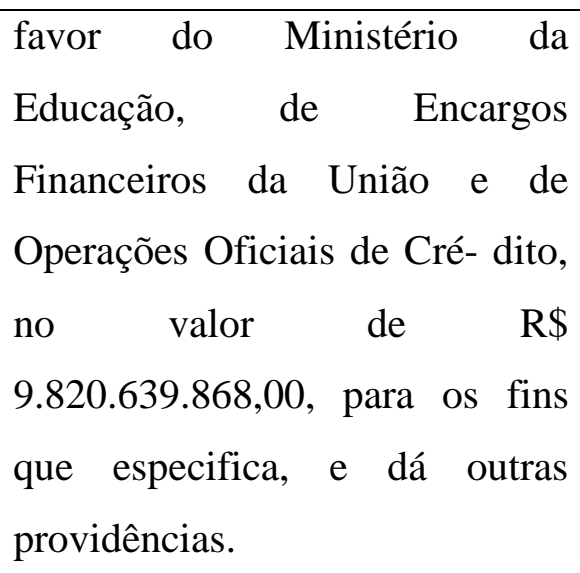 & Lei $13.181 / 2015$ \\
\hline 5 & $\begin{array}{l}\text { Publ. em DOU } \\
\text { 20.05.2015 }\end{array}$ & $\begin{array}{l}\text { Abre crédito extraordinário, em } \\
\text { favor dos Ministérios do } \\
\text { Desenvolvimento Agrário, da } \\
\text { Defesa e da Integração Nacional, } \\
\text { no valor de R } \$ 904.756 .882,00 \text {, } \\
\text { para os fins que especifica. }\end{array}$ & $\begin{array}{l}\text { Conversão em lei } \\
\text { Lei } 13.164 / 2015\end{array}$ \\
\hline 6 & $\begin{array}{l}\text { Publ. em DOU } \\
\text { 05.01.2015 }\end{array}$ & $\begin{array}{l}\text { Abre crédito extraordinário, em } \\
\text { favor dos órgãos e empresas } \\
\text { estatais, constantes do Projeto de } \\
\text { Lei Orçamentária de } 2015 \text {, no } \\
\text { valor de R } \$ 74.014 .218 .398,00 \text {, } \\
\text { para os fins que especifica. }\end{array}$ & $\begin{array}{l}\text { Vigência encerrada } \\
\text { Ato Declaratório } \\
22 / 2015\end{array}$ \\
\hline 7 & $\begin{array}{l}\text { Publ. em DOU } \\
\text { 31.12.2014 }\end{array}$ & $\begin{array}{l}\text { Abre crédito extraordinário, em } \\
\text { favor de diversos órgãos do } \\
\text { Poder Executivo, de Encargos } \\
\text { Financeiros da União, de } \\
\text { Transferências a Estados, } \\
\text { Distrito Federal e Municípios, de } \\
\text { Operações Oficiais de Crédito e } \\
\text { de empresas estatais vinculadas a } \\
\text { diversos órgãos, no valor de R\$ } \\
\text { 20.139.294.891,00, para os fins } \\
\text { que especifica. }\end{array}$ & $\begin{array}{l}\text { Vigência encerrada } \\
\text { Ato Declaratório } \\
21 / 2015\end{array}$ \\
\hline 8 & 662 , de 08.12 .2014 & $\begin{array}{l}\text { Abre crédito extraordinário, em } \\
\text { favor da empresa estatal }\end{array}$ & Vigência encerrada \\
\hline
\end{tabular}




\begin{tabular}{|c|c|c|c|}
\hline & $\begin{array}{l}\text { Publ. em DOU } \\
\text { 09.12.2014 }\end{array}$ & $\begin{array}{l}\text { Telecomunicações Brasileiras } \\
\text { S.A. - TELEBRÁS, no valor de } \\
\text { R\$ 404.755.786,00, para os fins } \\
\text { que especifica. }\end{array}$ & $\begin{array}{ll}\text { Ato } & \text { Declaratório } \\
19 / 2015 & \end{array}$ \\
\hline 9 & $\begin{array}{l}\text { Publ. em DOU } \\
\text { 11.11.2014 }\end{array}$ & $\begin{array}{l}\text { Abre crédito extraordinário, em } \\
\text { favor dos Ministérios das } \\
\text { Relações Exteriores e da Defesa } \\
\text { e de Encargos Financeiros da } \\
\text { União, no valor de R\$ } \\
1.773 .069 .612,00 \text {, para os fins } \\
\text { que especifica. }\end{array}$ & $\begin{array}{l}\text { Vigência encerrada } \\
\text { Ato Declaratório } \\
15 / 2015\end{array}$ \\
\hline 10 & $\begin{array}{l}\text { 655, de } 25.08 .2014 \\
\text { Publ. em D } \\
\text { 26.08.2014 }\end{array}$ & $\begin{array}{l}\text { Abre crédito extraordinário, em } \\
\text { favor de Operações Oficiais de } \\
\text { Crédito, no valor de R\$ } \\
5.400 .000 .000,00 \text {, para o fim } \\
\text { que especifica. }\end{array}$ & $\begin{array}{l}\text { Vigência encerrada } \\
\text { Ato Declaratório } \\
1 / 2015\end{array}$ \\
\hline 11 & $\begin{array}{l}\text { Publ. em DOU } \\
\text { 13.08.2014 }\end{array}$ & $\begin{array}{l}\text { Abre crédito extraordinário, em } \\
\text { favor de diversos órgãos do } \\
\text { Poder Executivo, no valor de } \mathrm{R} \$ \\
\text { 1.304.652.399,00, para os fins } \\
\text { que especifica. }\end{array}$ & $\begin{array}{l}\text { Vigência encerrada } \\
\text { Ato Declaratório } \\
48 / 2014\end{array}$ \\
\hline 12 & $\begin{array}{l}\text { Publ. em } \\
\text { 18.04.2014 }\end{array}$ & $\begin{array}{l}\text { Abre crédito extraordinário, em } \\
\text { favor do Ministério da Defesa e } \\
\text { de Operações Oficiais de } \\
\text { Crédito, no valor de } \mathrm{R} \$ \\
5.100 .000 .000,00 \text {, para os fins } \\
\text { que especifica. }\end{array}$ & Conversão em lei \\
\hline 13 & $\begin{array}{l}\text { Publ. em } \\
\text { 30.12.2013 }\end{array}$ & $\begin{array}{l}\text { Abre crédito extraordinário, em } \\
\text { favor de diversos órgãos do } \\
\text { Poder Executivo, no valor de } \mathrm{R} \$ \\
1.978 .600 .000,00 \text {, para os fins } \\
\text { que especifica. }\end{array}$ & Conversão em Lei \\
\hline 14 & 626 , de 24.10 .2013 & Abre crédito extraordinário, em & Conversão em lei \\
\hline
\end{tabular}




\begin{tabular}{|c|c|c|c|c|}
\hline & $\begin{array}{l}\text { Publ. em } \\
25.10 .2013\end{array}$ & DOU & $\begin{array}{l}\text { favor de Operações Oficiais de } \\
\text { Crédito, no valor de R\$ } \\
2.531 .486 .253,00 \text {, para o fim que } \\
\text { especifica. }\end{array}$ & Lei $12.956 / 2014$ \\
\hline 15 & $\begin{array}{l}\text { 625, de } 02.09 . \\
\text { Publ. em } \\
\text { 03.09.2013 }\end{array}$ & DOU & $\begin{array}{l}\text { Abre crédito extraordinário, em } \\
\text { favor do Ministério de Minas e } \\
\text { Energia, no valor de R\$ } \\
60.000 .000,00 \text {, para o fim que } \\
\text { especifica. }\end{array}$ & $\begin{array}{l}\text { Vigência encerrada } \\
\text { Ato declaratório 3/2014 }\end{array}$ \\
\hline 16 & $\begin{array}{l}\text { 624, de } 14.08 . \\
\text { Publ. em } \\
\text { 15.08.2013 }\end{array}$ & DOU & $\begin{array}{l}\text { Abre crédito extraordinário, em } \\
\text { favor de Encargos Financeiros } \\
\text { da União e de Transferências a } \\
\text { Estados, Distrito Federal e } \\
\text { Municípios, no valor de R\$ } \\
1.648 .000 .000,00 \text {, para os fins } \\
\text { que especifica. }\end{array}$ & $\begin{array}{l}\text { Conversão em Lei } \\
\text { Lei } 12.866 / 2013\end{array}$ \\
\hline 17 & $\begin{array}{l}\text { Publ. em } \\
\text { 10.07.2013 }\end{array}$ & DOU & $\begin{array}{l}\text { Abre crédito extraordinário, em } \\
\text { favor dos Ministérios das } \\
\text { Comunicações, } \\
\text { Desenvolvimento Agrário, da } \\
\text { Defesa e da Integração Nacional, } \\
\text { no valor de R\$ } \\
\text { 3.969.200.000,00, para os fins } \\
\text { que especifica. (Serviços de } \\
\text { telecomunicações, } \\
\text { Garantia-Safra, Fundo } \\
\text { Desenvolvimento Sustentável de } \\
\text { Territórios Rurais, Gestão de } \\
\text { Riscos e Resposta a Desastres.) }\end{array}$ & $\begin{array}{l}\text { Conversão em lei } \\
\text { Lei } 12.877 / 2013\end{array}$ \\
\hline 18 & $\begin{array}{l}\text { Publ. em } \\
\text { 31.05.2013 }\end{array}$ & DOU & $\begin{array}{l}\text { Abre crédito extraordinário, em } \\
\text { favor de Operações Oficiais de } \\
\text { Crédito, no valor de R\$ } \\
2.932 .125 .346,00 \text {, para o fim que }\end{array}$ & Conversão em Lei \\
\hline
\end{tabular}




\begin{tabular}{|c|c|c|c|}
\hline & & especifica. & \\
\hline 19 & $\begin{array}{l}\text { Publ. em DOU } \\
\text { 04.04.2013 }\end{array}$ & $\begin{array}{l}\text { Abre crédito extraordinário, em } \\
\text { favor dos Ministérios das } \\
\text { Comunicações, } \\
\text { Desenvolvimento Agrário, da } \\
\text { Defesa e da Integração Nacional, } \\
\text { no valor de para os fins } \\
\text { 3.969.200.000,00, pa } \\
\text { que especifica. }\end{array}$ & Conversão em Lei \\
\hline 20 & $\begin{array}{l}\text { Publ. em DOU } \\
\text { 21.01.2013 }\end{array}$ & $\begin{array}{l}\text { Abre crédito extraordinário, em } \\
\text { favor dos Ministérios do } \\
\text { Desenvolvimento Agrário e da } \\
\text { Integração Nacional, no valor de } \\
\text { R } \$ 361.368 .057,00 \text {, para os fins } \\
\text { que especifica. }\end{array}$ & $\begin{array}{l}\text { Vigência encerrada } \\
\text { Ato declaratório } \\
38 / 2013\end{array}$ \\
\hline 21 & $\begin{array}{l}\text { 598, de } 27.12 .2012 \\
\text { Publ. em DOU } \\
\text { 27.12.2012 }\end{array}$ & $\begin{array}{l}\text { Abre crédito extraordinário, em } \\
\text { favor de diversos órgãos e } \\
\text { empresas estatais, para os fins } \\
\text { que especifica. }\end{array}$ & $\begin{array}{l}\text { Vigência encerrada } \\
\text { Ato declaratório } \\
34 / 2013\end{array}$ \\
\hline 22 & $\begin{array}{l}\text { Publ. em DOU } \\
\text { 07.12.2012 }\end{array}$ & $\begin{array}{l}\text { Abre crédito extraordinário, em } \\
\text { favor dos Ministérios do } \\
\text { Desenvolvimento Agrário e da } \\
\text { Integração Nacional, no valor de } \\
\text { R } \$ 573.330 .080,00 \text {, para os fins } \\
\text { que especifica. }\end{array}$ & $\begin{array}{l}\text { Vigência encerrada } \\
\text { Ato declaratório } \\
32 / 2013\end{array}$ \\
\hline 23 & $\begin{array}{l}\text { Publ. em DOU } \\
\text { 13.11.2012 }\end{array}$ & $\begin{array}{l}\text { Abre crédito extraordinário, em } \\
\text { favor de Operações Oficiais de } \\
\text { Crédito, no valor de R\$ } \\
1.683 .716 .400,00 \text {, para o fim que } \\
\text { especifica. }\end{array}$ & Conversão em lei \\
\hline 24 & 583 , de 10.10 .2012 & $\begin{array}{l}\text { Abre crédito extraordinário, em } \\
\text { favor do Ministério da } \\
\text { Integração Nacional, no valor de }\end{array}$ & $\begin{array}{l}\text { Conversão em lei } \\
\text { Lei } 12.739 / 2012\end{array}$ \\
\hline
\end{tabular}




\begin{tabular}{|c|c|c|c|}
\hline & 10.10 .2012 & $\begin{array}{l}\mathrm{R} \$ 676.000 .000,00 \text {, para os fins } \\
\text { que especifica. }\end{array}$ & \\
\hline 25 & $\begin{array}{l}\text { Publ. em DOU } \\
28.06 .2012\end{array}$ & $\begin{array}{l}\text { Abre crédito extraordinário, em } \\
\text { favor dos Ministérios da Justiça, } \\
\text { da Educação, da Saúde, dos } \\
\text { Transportes, do Planejamento, } \\
\text { Orçamento e Gestão, do } \\
\text { Desenvolvimento Agrário, da } \\
\text { Defesa, da Integração Nacional e } \\
\text { das Cidades, no valor global de } \\
\text { R } \$ \text { 6.843.701.650,00, para os } \\
\text { fins que especifica. }\end{array}$ & $\begin{array}{l}\text { Conversão em lei } \\
\text { Lei } 12.729 / 2012\end{array}$ \\
\hline 26 & $\begin{array}{l}\text { 572, de } 05.06 .2012 \\
\text { Publ. em DOU } \\
\text { 06.06.2012 }\end{array}$ & $\begin{array}{l}\text { Abre crédito extraordinário, em } \\
\text { favor do Ministério da Defesa, } \\
\text { no valor de } \mathrm{R} \$ 381.252 .988,00 \text {, } \\
\text { para os fins que especifica. }\end{array}$ & $\begin{array}{l}\text { Conversão em lei } \\
\text { Lei } 12.728 / 2012\end{array}$ \\
\hline 27 & $\begin{array}{l}\text { 569, de } 14.05 .2012 \\
\text { Publ. em DOU } \\
\text { 15.05.2012 }\end{array}$ & $\begin{array}{l}\text { Abre crédito extraordinário, em } \\
\text { favor dos Ministérios da Defesa, } \\
\text { da Integração Nacional e do } \\
\text { Desenvolvimento Social e } \\
\text { Combate à Fome, no valor } \\
\text { global de R } \$ 688.497 .000,00 \text {, } \\
\text { para os fins que especifica. }\end{array}$ & $\begin{array}{l}\text { Conversão em lei } \\
\text { Lei } 12.713 / 2012\end{array}$ \\
\hline 28 & $\begin{array}{l}\text { Publ. em DOU } \\
25.04 .2012\end{array}$ & $\begin{array}{l}\text { Abre crédito extraordinário, em } \\
\text { favor dos Ministérios do } \\
\text { Desenvolvimento Agrário e da } \\
\text { Integração Nacional, no valor } \\
\text { global de R\$ 706.400.000,00, } \\
\text { para os fins que especifica. }\end{array}$ & Conversão em lei \\
\hline 29 & $\begin{array}{l}\text { Publ em DOU } \\
08.03 .2012\end{array}$ & $\begin{array}{l}\text { Abre crédito extraordinário, em } \\
\text { favor do Ministério da Defesa, } \\
\text { no valor de } \mathrm{R} \$ 40.000 .000,00 \text {, } \\
\text { para o fim que especifica. }\end{array}$ & $\begin{array}{l}\text { Conversão em lei } \\
\text { Lei } 12.680 / 2012\end{array}$ \\
\hline
\end{tabular}




\begin{tabular}{|c|c|c|c|}
\hline 30 & $\begin{array}{l}\text { Publ. em DOU } \\
31.10 .2011\end{array}$ & $\begin{array}{l}\text { Abre crédito extraordinário, em } \\
\text { favor dos Ministérios da Ciência, } \\
\text { Tecnologia e Inovação, da } \\
\text { Defesa e da Integração Nacional, } \\
\text { no valor global de R\$ } \\
533.581 .700,00 \text {, para os fins que } \\
\text { especifica. }\end{array}$ & Conversão em lei \\
\hline 31 & $\begin{array}{l}\text { Publ. em DOU } \\
\text { 31.10.2011 }\end{array}$ & $\begin{array}{l}\text { Abre crédito extraordinário, em } \\
\text { favor do Ministério da } \\
\text { Educação, no valor de R\$ } \\
460.530 .000,00 \text {, para o fim que } \\
\text { especifica. }\end{array}$ & $\begin{array}{l}\text { Conversão em lei } \\
\text { Lei } 12.606 / 2012\end{array}$ \\
\hline 32 & Publ. em 24.06.2011 & $\begin{array}{l}\text { Abre crédito extraordinário, em } \\
\text { favor dos Ministérios da Defesa } \\
\text { e da Integração Nacional, no } \\
\text { valor global de R\$ } \\
500.000 .000,00 \text {, para os fins que } \\
\text { especifica. }\end{array}$ & $\begin{array}{l}\text { Conversão em lei } \\
\text { Lei } 12.518 / 2011\end{array}$ \\
\hline 33 & $\begin{array}{l}\text { Publ. em DOU } \\
\text { 26.04.2011 }\end{array}$ & $\begin{array}{l}\text { Abre crédito extraordinário, em } \\
\text { favor do Ministério da } \\
\text { Educação, no valor de } \mathrm{R} \$ \\
74.000 .000,00 \text {, para os fins que } \\
\text { especifica. }\end{array}$ & $\begin{array}{l}\text { Conversão em lei } \\
\text { Lei } 12.471 / 2011\end{array}$ \\
\hline 34 & $\begin{array}{l}\text { Publ. em DOU } \\
\text { 13.01.2011 }\end{array}$ & $\begin{array}{l}\text { Abre crédito extraordinário, em } \\
\text { favor dos Ministérios dos } \\
\text { Transportes e da Integração } \\
\text { Nacional, no valor global de R\$ } \\
780.000 .000,00 \text {, para os fins que } \\
\text { especifica. }\end{array}$ & $\begin{array}{l}\text { Vigência encerrada } \\
\text { Ato declaratório } \\
31 / 2011\end{array}$ \\
\hline 35 & $\begin{array}{l}\text { Publ. em DOU } \\
28.12 .2010\end{array}$ & $\begin{array}{l}\text { Abre crédito extraordinário em } \\
\text { favor da Justiça do Trabalho e de } \\
\text { diversos órgãos do Poder } \\
\text { Executivo, no valor global de R\$ }\end{array}$ & $\begin{array}{l}\text { Conversão em lei } \\
\text { Lei } 12.414 / 2011\end{array}$ \\
\hline
\end{tabular}




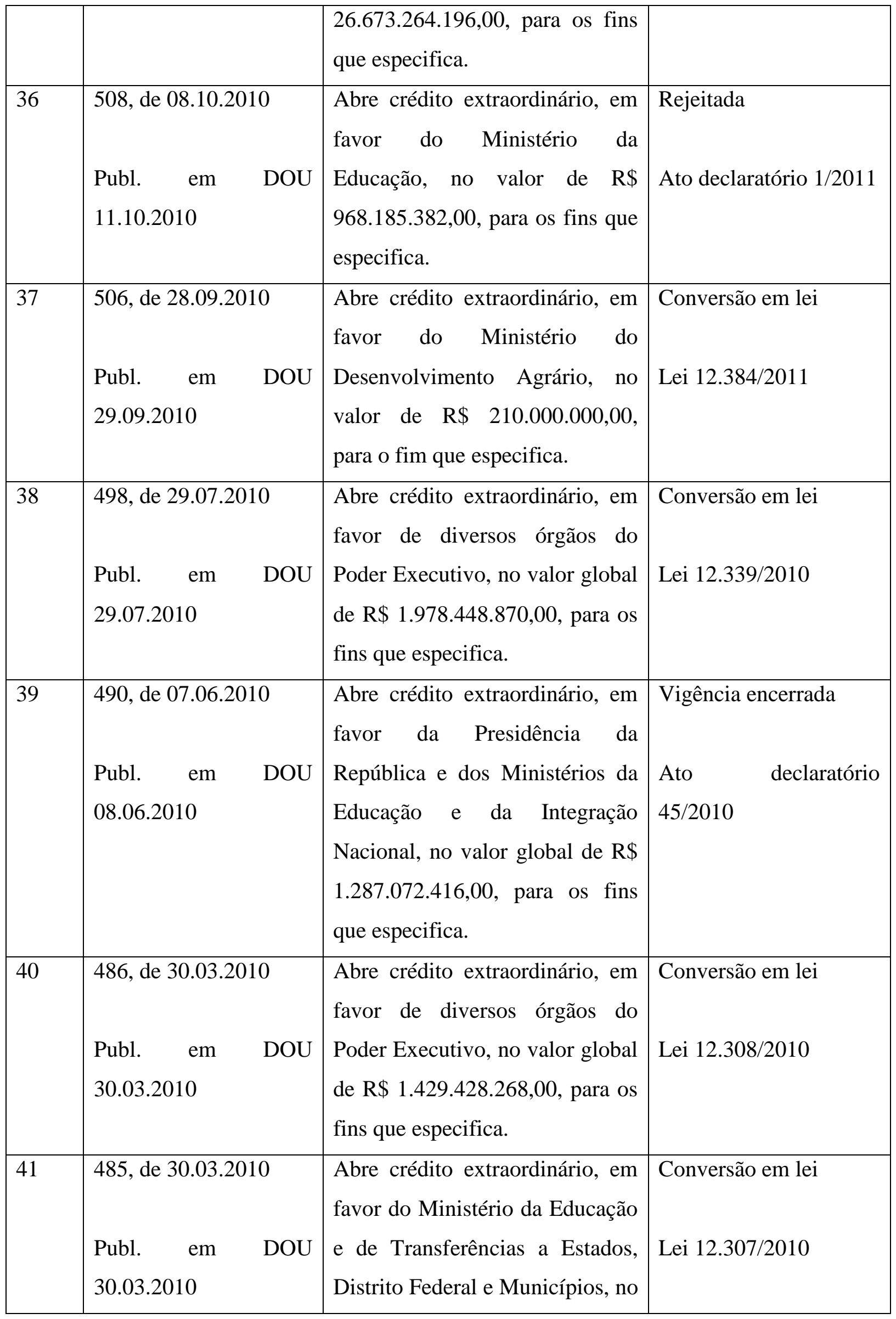




\begin{tabular}{|c|c|c|c|}
\hline & & 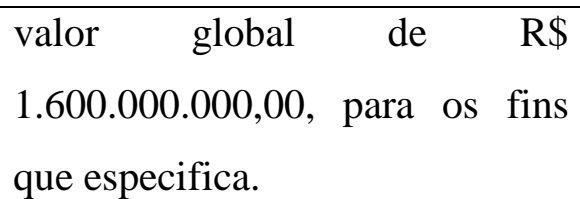 & \\
\hline 42 & $\begin{array}{l}\text { Publ. em DOU } \\
\text { 27.01.2010 }\end{array}$ & $\begin{array}{l}\text { Abre crédito extraordinário, em } \\
\text { favor da Presidência da } \\
\text { República, dos Ministérios da } \\
\text { Agricultura, Pecuária } \\
\text { Abastecimento, das Relações } \\
\text { Exteriores, da Saúde, da Defesa, } \\
\text { da Integração Nacional e das } \\
\text { Cidades, e de Transferências a } \\
\text { Estados, Distrito Federal e } \\
\text { Municípios, no valor global de } \\
\text { R\$ 1.374.057.000,00, para os } \\
\text { fins que especifica. }\end{array}$ & Conversão em lei \\
\hline 43 & $\begin{array}{l}\text { 477, de } 29.12 .2009 \\
\text { Publ. em DOU } \\
29.12 .2009\end{array}$ & $\begin{array}{l}\text { Abre crédito extraordinário, em } \\
\text { favor de diversos órgãos e } \\
\text { entidades do Poder Executivo, } \\
\text { no valor global de R\$ } \\
\text { 18.191.723.573,00, e reduz o } \\
\text { Orçamento de Investimento de } \\
\text { diversas empresas no valor } \\
\text { global de R } \$ 5.736 .743 .280,00 \text {, } \\
\text { para os fins que especifica. }\end{array}$ & $\begin{array}{l}\text { Conversão em lei } \\
\text { Lei } 12.240 / 2010\end{array}$ \\
\hline 44 & $\begin{array}{l}\text { Publ. em DOU } \\
\text { 16.12.2009 }\end{array}$ & $\begin{array}{l}\text { Abre crédito extraordinário, em } \\
\text { favor dos Ministérios da } \\
\text { Agricultura, Pecuária } \\
\text { Abastecimento, da Educação, da } \\
\text { Saúde, dos Transportes e da } \\
\text { Integração Nacional, no valor } \\
\text { global de R\$ 742.000.000,00, } \\
\text { para os fins que especifica. }\end{array}$ & $\begin{array}{l}\text { Conversão em Lei } \\
\text { Lei } 12.233 / 2010\end{array}$ \\
\hline 45 & 469 , de 20.05.2009 & Abre crédito extraordinário, em & Conversão em Lei \\
\hline
\end{tabular}




\begin{tabular}{|c|c|c|c|c|}
\hline & $\begin{array}{l}\text { Publ. em } \\
21.05 .2009\end{array}$ & DOU & $\begin{array}{l}\text { favor de diversos órgãos do } \\
\text { Poder Executivo, no valor global } \\
\text { de R\$ 1.217.677.730,00, para os } \\
\text { fins que especifica. }\end{array}$ & Lei 11.981/2009 \\
\hline 46 & $\begin{array}{l}\text { Publ. em } \\
\text { 16.04.2009 }\end{array}$ & DOU & $\begin{array}{l}\text { Abre crédito extraordinário, em } \\
\text { favor do Ministério da } \\
\text { Integração Nacional, no valor de } \\
\text { R } \$ 300.000 .000,00 \text {, para os fins } \\
\text { que especifica. }\end{array}$ & Conversão em Lei \\
\hline 47 & $\begin{array}{l}\text { Publ. em } \\
\text { 26.11.2008 }\end{array}$ & DOU & $\begin{array}{l}\text { Abre crédito extraordinário, em } \\
\text { favor da Presidência da } \\
\text { República e dos Ministérios da } \\
\text { Saúde, dos Transportes, da } \\
\text { Defesa e da Integração Nacional, } \\
\text { no valor global de R\$ } \\
1.600 .000 .000,00 \text {, para os fins } \\
\text { que especifica. }\end{array}$ & Conversão em Lei \\
\hline 48 & $\begin{array}{l}\text { Publ. em } \\
\text { 14.05.2008 }\end{array}$ & DOU & $\begin{array}{l}\text { Abre crédito extraordinário, em } \\
\text { favor do Ministério do } \\
\text { Planejamento, Orçamento e } \\
\text { Gestão, no valor de R\$ } \\
7.560 .000 .000,00 \text {, e dá outras } \\
\text { providências. }\end{array}$ & $\begin{array}{l}\text { Rejeitada } \\
\text { Ato declaratório da } \\
\text { Presidência da Câmara } \\
\text { dos Deputados - Publ. } \\
\text { em 10.07.2008 }\end{array}$ \\
\hline 49 & $\begin{array}{l}\text { Publ. em } \\
\text { 17.04.2008 }\end{array}$ & DOU & $\begin{array}{l}\text { Abre crédito extraordinário, em } \\
\text { favor de diversos órgãos do } \\
\text { Poder Executivo, no valor global } \\
\text { de R } \$ 1.816 .577 .877,00 \text {, para os } \\
\text { fins que especifica. }\end{array}$ & Conversão em Lei \\
\hline 50 & $\begin{array}{l}\text { Publ. em } \\
\text { 04.04.2008 }\end{array}$ & DOU & $\begin{array}{l}\text { Abre crédito extraordinário, em } \\
\text { favor dos Ministérios dos } \\
\text { Transportes e da Integração } \\
\text { Nacional, no valor global de R\$ } \\
613.752 .057,00 \text {, para os fins que }\end{array}$ & $\begin{array}{l}\text { Conversão em Lei } \\
\text { Lei } 11.710 / 2008\end{array}$ \\
\hline
\end{tabular}




\begin{tabular}{|l|l|l|l|}
\hline 51 & 420, de 25.02.2008 & especifica. & \\
& & $\begin{array}{l}\text { Abre crédito extraordinário, em } \\
\text { favor de Encargos Financeiros }\end{array}$ & Conversão em lei \\
& $\begin{array}{l}\text { Publ. em DOU } \\
\text { da União, no valor de R\$ } \\
26.02 .2008\end{array}$ & Lei 11.708/2008 \\
& & $\begin{array}{l}12.500 .000 .000,00, \text { para o fim } \\
\text { que especifica. }\end{array}$ & \\
\hline
\end{tabular}

Fontes: <http://www.secretariadegoverno.gov.br/sobre/assuntos_parlamentares/medidas-provisorias〉; e $<$ http://www.planalto.gov.br/ccivil_03/mpv/principal.htm〉. Acesso em: 18.05.2016. 


\section{ANEXO D - AÇÕES DIRETAS DE INCONSTITUCIONALIDADE AJUIZADAS EM \\ FACE DE MEDIDA PROVISÓRIA QUE VEICULE ABERTURA DE CRÉDITO EXTRAORDINÁRIO}

Em termos metodológicos, realizou-se pesquisa no banco de dados do sítio eletrônico do Supremo Tribunal Federal relativa às ações diretas de inconstitucionalidade, a partir da expressão "crédito extraordinário". Logo, houve limitação quanto à classe processual, no entanto não existiu limitação temporal, de modo que o marco inicial é o advento da CR/88 na qual se previu a ADI e o termo final, a data de acesso ao sítio eletrônico do STF (20.05.2016). De plano, chegou-se ao número de 29 (vinte e nove) AADDI como resultado dessa busca.

Depois disso, optou-se por excluir os feitos em que o objeto da ação não era MP veiculadora de abertura de créditos extraordinários, de modo que 9 (nove) feitos foram retirados do universo de análise.

Enfim, remanesceram 20 ações de índole objetiva, todas oriundas do Distrito Federal, que foram sistematizadas para a análise levada a efeito no Capítulo 3 desta pesquisa, em ordem cronológica decrescente, no seguinte quadro:

Quadro 6 - Lista de Ações Diretas de Inconstitucionalidade ajuizadas em face de medidas provisórias cujos objetos sejam a abertura de crédito extraordinário

\begin{tabular}{|c|c|c|c|c|}
\hline ADI & Requerente & Ministro Relator & Órgão Judicante & Decisão \\
\hline $\begin{array}{l}5.513 \\
\text { Em } \\
\text { aberto }\end{array}$ & Solidariedade & Gilmar Mendes & $\begin{array}{l}\text { Monocrática } \\
\text { Ad referendum } \\
\text { do } \quad \text { Tribunal } \\
\text { Pleno, } \\
\text { termos do art. } \\
21, \mathrm{~V} \text {, do RISTF }\end{array}$ & $\begin{array}{l}\text { Medida cautelar } \\
\text { parcialmente } \\
\text { deferida } \\
\text { j. } 30.04 .2016 \\
\text { DJe } 04.05 .2016\end{array}$ \\
\hline $\begin{array}{l}4.904 \\
\text { Em } \\
\text { aberto }\end{array}$ & $\begin{array}{l}\text { Partido da } \quad \text { Social } \\
\text { Democracia } \\
\text { (PSDBsileira }\end{array}$ & Marco Aurélio & $\begin{array}{l}\text { Monocrática } \\
\text { (VP do STF em } \\
\text { recesso forense, } \\
\text { nos termos do } \\
\text { art. 13, VIII, do } \\
\text { RISTF) }\end{array}$ & $\begin{array}{l}\text { Medida cautelar } \\
\text { indeferida } \\
\text { j. } 25.01 .2013 \\
\text { DJe } 1^{\circ} .02 .2013\end{array}$ \\
\hline 4.607 & Democratas (DEM) & Roberto Barroso & Monocrática & Prejudicada \\
\hline
\end{tabular}




\begin{tabular}{|c|c|c|c|c|}
\hline & & & & $\begin{array}{l}\text { Eficácia } \\
\text { Exaurida } \\
\text { j. } 27.10 .2015 \\
\text { DJe } 28.10 .2015\end{array}$ \\
\hline 4.602 & $\begin{array}{l}\text { Partido da } \quad \text { Social } \\
\text { Democracia } \text { Brasileira } \\
\text { (PSDB) }\end{array}$ & Roberto Barroso & Monocrática & $\begin{array}{l}\text { Prejudicada } \\
\text { Eficácia } \\
\text { Exaurida } \\
\text { j. } 27.10 .2015 \\
\text { DJe } 29.10 .2015\end{array}$ \\
\hline 4.365 & $\begin{array}{l}\text { Partido da } \text { Social } \\
\text { Democracia } \text { Brasileira } \\
\text { (PSDB) }\end{array}$ & Dias Toffoli & Tribunal Pleno & $\begin{array}{l}\text { Prejudicada } \\
\text { Eficácia } \\
\text { Exaurida } \\
\text { j. 05.03.2015 } \\
\text { DJe 08.05.2015 }\end{array}$ \\
\hline 4.098 & $\begin{array}{l}\text { Partido da } \text { Social } \\
\text { Democracia } \text { Brasileira } \\
\text { (PSDB) }\end{array}$ & Ayres Britto & Monocrática & $\begin{array}{l}\text { Prejudicada } \\
\text { Falta de } \\
\text { aditamento da } \\
\text { inicial } \\
\text { j. 07.08.2009 } \\
\text { DJe 18.08.2009 }\end{array}$ \\
\hline 4.050 & $\begin{array}{l}\text { Partido da } \quad \text { Social } \\
\text { Democracia } \text { Brasileira } \\
\text { (PSDB) }\end{array}$ & Menezes Direito & Monocrática & $\begin{array}{l}\text { Não conhecida } \\
\text { j. 13.03.2008 } \\
\text { DJe 27.03.2008 }\end{array}$ \\
\hline 4.049 & $\begin{array}{l}\text { Partido da } \quad \text { Social } \\
\text { Democracia } \text { Brasileira } \\
\text { (PSDB) }\end{array}$ & $\begin{array}{l}\text { Ayres Britto/ } \\
\text { Teori Zavascki }\end{array}$ & $\begin{array}{l}\text { Tribunal Pleno/ } \\
\text { monocrática }\end{array}$ & $\begin{array}{l}\text { Medida Cautelar } \\
\text { deferida } \\
\text { j. 05.11.2008 } \\
\text { DJe 08.05.2009 } \\
\text { Prejudicada } \\
\text { Eficácia } \\
\text { exaurida } \\
\text { j. 10.03.2016 } \\
\text { DJe 16.03.2016 }\end{array}$ \\
\hline 4.048 & Partido da $\quad$ Social & Gilmar Mendes/ & Tribunal Pleno/ & Medida Cautelar \\
\hline
\end{tabular}




\begin{tabular}{|c|c|c|c|c|}
\hline & $\begin{array}{l}\text { Democracia } \text { Brasileira } \\
\text { (PSDB) }\end{array}$ & Ellen Gracie & monocrática & $\begin{array}{l}\text { deferida } \\
\text { j. 14.05.2008 } \\
\text { DJe 22.08.2008 } \\
\text { Prejudicada } \\
\text { Eficácia } \\
\text { exaurida } \\
\text { j. 14.02.2011 } \\
\text { DJe 22.02.2011 }\end{array}$ \\
\hline $\begin{array}{l}4.047 \\
\text { Em } \\
\text { aberto }\end{array}$ & $\begin{array}{l}\text { Partido da } \text { Social } \\
\text { Democracia } \text { Brasileira } \\
\text { (PSDB) }\end{array}$ & Roberto Barroso & -------//------- & Sem decisão \\
\hline 4.046 & $\begin{array}{l}\text { Partido da } \text { Social } \\
\text { Democracia Brasileira } \\
\text { (PSDB) }\end{array}$ & $\begin{array}{l}\text { Ricardo } \\
\text { Lewandowski }\end{array}$ & Monocrática & $\begin{array}{l}\text { Prejudicada } \\
\text { Eficácia } \\
\text { exaurida } \\
\text { j. } 29.05 .2012 \\
\text { DJe } 1^{\circ} .06 .2012\end{array}$ \\
\hline 4.045 & $\begin{array}{l}\text { Partido da } \text { Social } \\
\text { Democracia Brasileira } \\
\text { (PSDB) }\end{array}$ & Eros Grau & Monocrática & $\begin{array}{l}\text { Prejudicada } \\
\text { Eficácia } \\
\text { exaurida } \\
\text { j. 04.02.2009 } \\
\text { DJe 11.02.2009 }\end{array}$ \\
\hline 4.044 & $\begin{array}{l}\text { Partido da } \text { Social } \\
\text { Democracia } \text { Brasileira } \\
\text { (PSDB) }\end{array}$ & Celso de Mello & Monocrática & $\begin{array}{l}\text { Prejudicada } \\
\text { Eficácia } \\
\text { exaurida } \\
\text { j. 10.08.2009 } \\
\text { DJe 17.08.2009 }\end{array}$ \\
\hline 4.041 & Democratas (DEM) & Dias Toffoli & Tribunal Pleno & $\begin{array}{l}\text { Prejudicada } \\
\text { Eficácia } \\
\text { exaurida } \\
\text { j. } 24.03 .2011 \\
\text { DJe 14.06.2011 }\end{array}$ \\
\hline 4.038 & $\begin{array}{l}\text { Partido da } \text { Social } \\
\text { Democracia } \quad \text { Brasileira }\end{array}$ & Roberto Barroso & Monocrática & $\begin{array}{l}\text { Prejudicada } \\
\text { Eficácia }\end{array}$ \\
\hline
\end{tabular}




\begin{tabular}{|c|c|c|c|c|}
\hline & (PSDB) & & & $\begin{array}{l}\text { exaurida } \\
\text { j. 20.11.2015 } \\
\text { DJe 15.02.2016 }\end{array}$ \\
\hline 3.891 & $\begin{array}{l}\text { Partido Popular } \\
\text { Socialista (PPS) }\end{array}$ & $\begin{array}{l}\text { Ricardo } \\
\text { Lewandowski }\end{array}$ & Monocrática & $\begin{array}{l}\text { Prejudicada } \\
\text { Eficácia } \\
\text { exaurida } \\
\text { j. } 29.05 .2012 \\
\text { DJe } 1^{\circ} .06 .2012\end{array}$ \\
\hline 3.712 & $\begin{array}{l}\text { Partido da } r \text { Social } \\
\text { Democracia Brasileira } \\
\text { (PSDB) }\end{array}$ & Cezar Peluso & Tribunal Pleno & $\begin{array}{l}\text { Prejudicada } \\
\text { Eficácia } \\
\text { exaurida } \\
\text { j. 29.02.2012 } \\
\text { DJe 25.05.2012 }\end{array}$ \\
\hline 3.709 & $\begin{array}{l}\text { Partido da } \\
\text { Liberal (PFL) }\end{array}$ & Cezar Peluso & Monocrática & $\begin{array}{l}\text { Não conhecida } \\
\text { j. 05.05.2006 } \\
\text { DJ 15.05.2006 }\end{array}$ \\
\hline 3.487 & $\begin{array}{l}\text { Partido da } \text { Social } \\
\text { Democracia Brasileira } \\
\text { (PSDB) }\end{array}$ & Ellen Gracie & Monocrática & $\begin{array}{l}\text { Não conhecida } \\
\text { j. 09.05.2005 } \\
\text { DJ 17.05.2005 }\end{array}$ \\
\hline 1.496 & $\begin{array}{l}\text { Partido Comunista do } \\
\text { Brasil (Pc do B), Partido } \\
\text { Democrático } \\
\text { Trabalhista (PDT) e } \\
\text { Partido dos } \\
\text { Trabalhadores (PT) }\end{array}$ & Moreira Alves & Tribunal Pleno & $\begin{array}{l}\text { Não conhecida } \\
\text { j. 21.11.1996 } \\
\text { DJ 18.05.2001 }\end{array}$ \\
\hline
\end{tabular}

Fonte: 〈https://www.stf.jus.br〉. Acesso em 20.05.2016. 